\title{
ANCIENT CLIMATE AND ENVIRONMENTAL HISTORY FROM \\ PHYTOLITH-OCCLUDED CARBON
}

By

JOHN ALEC CARTER

\author{
A thesis \\ submitted to the Victoria University of Wellington \\ in fulfilment of the requirements for the degree of \\ Doctor of Philosophy \\ in Geology
}

Victoria University of Wellington 2007 


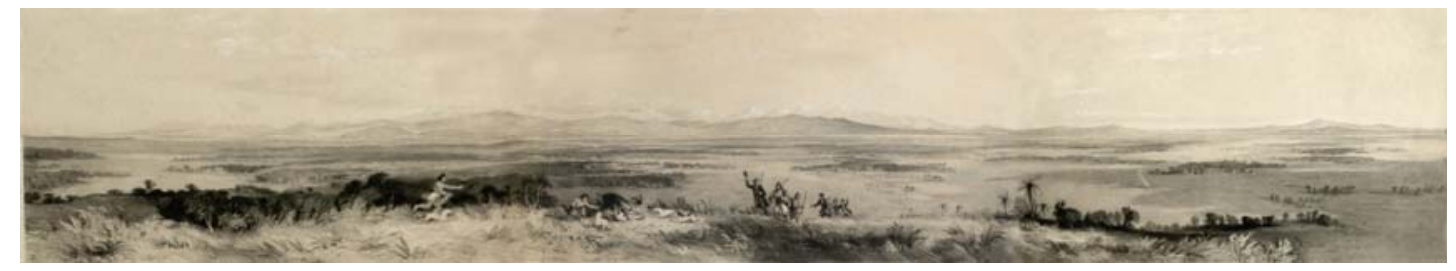

Panorama of the Wairarapa looking west, drawn by Samuel Charles Brees in the early 1840's. From: Illustrations to Adventure in New Zealand by Edward J. Wakefield.

"What happened under the low green tarred branch of the Ngaio tree cannot be clearly remembered but determined what we know now"-.

James K. Baxter, The Ngaio Tree. 


\section{ABSTRACT \\ Ancient Climate and Environmental History from Phytolith-occluded Carbon}

The best records of atmospheric change of glacial cycles are those from ice cores. However, ice cores cannot provide estimates of changes in atmospheric ${ }^{13} \mathrm{CO}_{2}$ because of as of yet unresolved technical problems. One of the least understood and important influences on the changes to the isotopic composition of atmospheric $\mathrm{CO}_{2}$ are that of vascular plants. While marine benthic $\delta^{13} \mathrm{C}$ records have been used to infer past changes in terrestrial vegetation, accurate estimation of changes in carbon storage on land during ice ages has proved elusive. Other estimates have been made from terrestrial biomes of pollen records but a large discrepancy between marine and land based estimates remains.

This thesis offers a new method of deriving an ancient atmospheric $\delta^{13} \mathrm{CO}_{2}$ record using measurements of phytolith-occluded carbon as a proxy. The method is designed to measure $\delta^{13} \mathrm{CO}_{2}$ in ancient phytolith-occluded carbon and convert this signal into an atmospheric $\delta^{13} \mathrm{CO}_{2}$ estimate for the atmosphere. Phytoliths are very small particles of silica (between 5 and 100 microns) that form distinctive and repeatable shapes in most plants. When phytoliths form within a plant, some of the host organic matter is trapped inside the phytolith. Phytoliths have been shown to contain occluded carbon and are present in most terrestrial sedimentary deposits. Moreover, because they survive well in most soils and sediments, the trapped carbon remains intact and preserved from contamination and alteration.

Experiments were conducted to characterise and measure the natural variability of modern phytolith-occluded carbon. These included measurement of carbon isotopic fractionation effects between the atmosphere and whole plant material, measurement of carbon isotope fractionation between whole plant matter and phytolith-occluded carbon, and a determination of carbon compounds present in phytolith-occluded carbon. A formula was developed for separating the plant physiological factors from the atmospheric ${ }^{13} \mathrm{CO}_{2}$ value in the phytolithoccluded carbon, thus providing a basis for estimating atmospheric ${ }^{13} \mathrm{CO}_{2}$ values.

Phytoliths were extracted and occluded carbon analysed from a 7.4m loess core. Changes in phytolith assemblages were used to create a direct record of changes to the local vegetation cover, and isotopic analyses of carbon in phytoliths to generate a record of atmospheric ${ }^{13} \mathrm{CO}_{2}$ for the last 120,000 years. The record exhibits a number of periods when the atmosphere had very low $\delta^{13} \mathrm{CO}_{2}$ values that correspond with $\mathrm{CH}_{4}$ peaks in the Vostok ice core. It is hypothesized here that these low values are a consequence of the release of large volumes of methane released from marine hydrate (clathrate) deposits into the atmosphere, thereby, diluting atmospheric ${ }^{13} \mathrm{CO}_{2}$. 


\section{CONTENTS}

\subsection{Chapter One: \\ Introduction}

$\begin{array}{llr}1.1 & \text { Overview } & 1\end{array}$

1.2 The Purpose and Scope of this Thesis. 3

1.3 Field Location and Sampling of the Otaraia Loess Section. 4

1.4 A Brief History of Phytoliths. 6

1.5 Phytolith Formation. 6

1.6 Composition, Characteristics and Function. 9

$\begin{array}{lll}1.7 & \text { Form and Preservation. } & 10\end{array}$

$\begin{array}{lll}1.8 & \text { Terminology and Classification. } & 11\end{array}$

$\begin{array}{lll}1.9 & \text { Paleoenvironmental Reconstruction. } & 13\end{array}$

$\begin{array}{lll}1.10 & \text { Chronology. } & 16\end{array}$

$\begin{array}{lll}1.11 & \text { Advances in Chemical Analysis. } & 17\end{array}$

1.12 Phytoliths in Archaeological Research. 17

1.13 Stable Isotope Analysis $r$

1.13.1 Oxygen. $\quad 19$

$\begin{array}{ll}\text { 1.13.2 Carbon. } & 20\end{array}$

1.13.2.1 DNA 22

1.13.2.2 Stability of Phytolith-Occluded Carbon 22

1.14 Phytolith History in New Zealand. 24

$\begin{array}{llr}1.15 & \text { Conclusions. } & 24\end{array}$

2.0 Chapter Two: 26

Paleoenvironmental Reconstruction using Phytolith Morphologies from Otaraia, Wairarapa

$\begin{array}{llr}2.1 & \text { Introduction. } & 26\end{array}$

$\begin{array}{lll}2.2 & \text { Previous work. } & 28\end{array}$

$\begin{array}{lll}2.3 & \text { Study Area. } & 28\end{array}$ 
2.3.1 Weather and Climate 29

2.3.2 Primeval, Recent Historic and Modern Vegetation. 29

2.4 Description and Age of the Loess Section at Otaraia. 30

$\begin{array}{lll}2.5 & \text { Age Model. } & 31\end{array}$

$\begin{array}{lll}2.6 & \text { Methods. } & 33\end{array}$

$\begin{array}{lll}2.7 & \text { Results. } & 33\end{array}$

$\begin{array}{lll}2.8 & \text { Discussion. } & 37\end{array}$

$\begin{array}{lll}\text { 2.8.1 Chronology. } & 38\end{array}$

$\begin{array}{ll}\text { 2.8.2 Sedimentology. } & 39\end{array}$

2.9 Paleoenvironmental Interpretation. $\quad 41$

$\begin{array}{lll}2.10 & \text { Conclusions. } & 51\end{array}$

3.0 Chapter Three: 53

Carbon Isotope Signatures in Modern Plant Phytolith and Whole Leaf Material

$\begin{array}{lll}3.1 & \mathbf{5 3}\end{array}$

3.2 Fractionation of Atmospheric Carbon Dioxide in Whole Plant Material. $\quad 53$

3.3 A History of Research into the use of C Isotopes in Phytoliths. 56

$\begin{array}{lll}3.4 & \text { Methods. } & 61\end{array}$

3.4.1 Sample Preparation and Phytolith Extraction from Modern Plant Material. $\quad 63$

$\begin{array}{lr}\text { 3.4.2 Carbon Isotope Analysis. } & 63\end{array}$

$\begin{array}{lll}3.5 & \text { Results: } & 64\end{array}$

$\begin{array}{llr}\text { 3.5.1 Pilot study. } & 64\end{array}$

$\begin{array}{ll}\text { 3.5.2 Main Study Results. - } & 65\end{array}$

3.5.3 Carbon Compounds Present within Phytolith-Occluded Carbon. 69

$\begin{array}{lll}3.6 & \text { Discussion. } & 72\end{array}$

3.6.1 Comparison with Previous Work and Samples Grown Under Different $\mathrm{CO}_{2}$ Concentrations. $\quad 72$

$\begin{array}{lll}\text { 3.6.2 } & \text { Possible Seasonal Fractionation Effects. } & 74\end{array}$ 
3.6.3 Atmospheric $\delta^{13} \mathrm{CO}_{2}$ for Carbon from Modern Plant Phytoliths. $\quad 77$

3.7 Conclusions.

4.0 Chapter 4:

81

Atmospheric $\delta^{13} \mathrm{CO}_{2}$ Signal from Ancient

Phytolith-Occluded Carbon

$\begin{array}{lll}4.1 & \text { Introduction } & 81\end{array}$

$\begin{array}{lll}4.2 & \text { Results and Initial Assessment. } & 84\end{array}$

$\begin{array}{lll}4.3 & \text { Influence of Vegetation Type. } & 86\end{array}$

$\begin{array}{lll}4.4 & \text { Ancient Atmospheric } \delta^{13} \mathrm{CO}_{2} \text { Signal. } & 88\end{array}$

4.5 Comparison between Otaraia and Byrd Ice-Core $\delta^{13} \mathrm{CO}_{2}$ Data. 93

\subsubsection{Errors}

95

$\begin{array}{lll}\text { 4.6 Processes Affecting Carbon Sources and Sinks } & 96\end{array}$

4.7 Comparison between Otaraia and Vostok $\mathrm{CO}_{2}$ and $\mathrm{CH}_{4}$ Data. 99

5.0 Chapter Five: Summary and Conclusions $\quad 104$

$\begin{array}{lr}\text { Acknowledgements } & 107\end{array}$

$\begin{array}{lr}\text { References } & 108\end{array}$

Appendix 1: Luminescence Dating of Three Samples 126

Appendix 2: Phytolith Counts from Otaraia Loess Sample 129

Appendix 3: Analysis of $125 \mathrm{ka}$ Atmospheric $\delta^{13} \mathrm{CO}_{2}$ Record 131

Appendix 4: Analysis of $\delta^{13} \mathrm{C}$ from Ancient Phytoliths 133

Appendix 5: Analysis of $\delta^{13} \mathrm{C}$ from Plants and Phytoliths from Pilot Study 138

Appendix 6: Analysis of $\delta^{13} \mathrm{C}$ from Plants from Main Study 140

Appendix 7: Analysis of $\delta^{13} \mathrm{C}$ from Phytoliths from Main Study 143 


\section{LIST OF TABLES}

Table 1.1: List of publications where phytoliths have been used in research in New Zealand.

Table 2.1: Measured a-values and equivalent dose-rates and luminescence Ages

Table 3.1: Pilot study results from analyses of percentage carbon $\delta^{13} \mathrm{C}$.

Table 3.2: Record of plant species from the main study.

Table 3.4: Seasonal differences in phytolith-occluded $\delta^{13} \mathrm{C}$.

Table 4.1: Estimates and averages of changes in carbon stored in terrestrial biosphere since the LGM.

Table 4.2: Otaraia phytolith $\delta^{13} \mathrm{C}$ values and depths.

Table 4.3: Average mean and standard deviation values from the Otaraia core

97

Table 4.4: Correlation between low $\delta^{13} \mathrm{CO}_{2}$ episodes at Otaraia and $\mathrm{CH}_{4}$ spikes in Vostok Ice Core. 


\section{LIST OF FIGURES}

Frontispiece: Panorama of the Wairarapa

Fig. 1.1: Photomicrograph showing a typical grassland phytolith assemblage extracted from a loess sample from South Wairarapa.

Fig. 1.2: Location of Otaraia drill site and other locations mentioned in this thesis.

Fig. 1.3: Photomicrograph of an anticlinal phytolith from a modern fern Blechnum sp.

Fig. 1.4: Fragile (polyhedral) tree phytoliths from modern native New Zealand Nothofagus solandri var solandri.

Fig. 1.5: Globular tree phytoliths from modern native New Zealand tree Knightia excelsa.

Fig. 1.6: Some of the internationally defined morphological phytolith shapes.

Fig. 1.7: Diagram showing the changes in phytolith assemblages from Bidwill Hill, Wairarapa, New Zealand.

Fig 1.8: Microprobe image showing occluded carbon within a phytolith from Festuca novae-zelandiae.

Fig. 2.1: Examples of phytoliths extracted from Otaraia loess core.

Fig. 2.2: Diagram of the Otaraia loess profile, mean grain size, sand, silt and clay percentages, major elements, iron and phosphorus and an age model showing the derived ages of Palmer (1982), the Kawakawa Tephra and OSL ages of this study.

Fig. 2.3: Phytolith stratigraphic frequency diagram.

Fig. 2.4: Correlation diagram of ${ }^{18} \mathrm{O}$ SPAMAP data, and MIS of Martinson et al. (1987), Vostok temperature $\left({ }^{\circ} \mathrm{C}\right)$ data of Petit et al. (2000), and Otaraia phytolith data (this study).

Fig. 2.5: Correlation diagram of insolation values for $40^{\circ} \mathrm{S}$ and $65^{\circ} \mathrm{N}$ through last glacial cycle, pollen data form Okarito (Vandergoes et al. 2005), phytolith data from Otaraia (this study).

Fig. 2.6: Panorama of the Wairarapa.

Fig. 3.1: Absorption of Carbon Dioxide. 
Fig. 3.2: Microprobe image of a cross-sectioned phytolith extracted from Festuca novae zelandiae.

Fig. 3.3: Carbon occlusion during phytolith formation.

Fig 3.4: Pilot study $\delta^{13} \mathrm{C} \%$ fractionation between plant material and phytolith-occluded carbon extracted from the same material

Fig. 3.5: Combined carbon isotope analysis records from all New Zealand plant species.

Fig. 3.6: NMR spectra of Festuca novae-zelandiae (grass) and Nothofagus solandri (tree).

Fig. 4.1: Diagram of Otaraia core $\delta{ }^{13} \mathrm{C}$ values plotted against depth.

Fig. 4.2: Results from modelling show the possible influence of floral type on $\delta^{13} \mathrm{C}$ values.

Fig. 4.3: Schematic showing the various stages involved in deriving a $\delta^{13} \mathrm{C}$ signal from ancient phytolith-occluded carbon.

Fig. 4.4: Otaraia atmospheric $\delta^{13} \mathrm{C}$ data.

Fig. 4.5: Correlation diagram of Byrd ice-core and Otaraia $\delta^{13} \mathrm{CO}_{2}$ values.

Fig. 4.6: Atmospheric $\delta^{13} \mathrm{C}$, Organic $\delta^{13} \mathrm{C}, \mathrm{CO}_{2}$ and $\mathrm{CH}_{4}$ Records. 


\section{Chapter 1:}

\section{Introduction}

\subsection{Overview}

The widespread acceptance that human activity is changing the earth's climate is leading us to realize that understanding past environmental and climatic change is crucial to our future wellbeing. Key questions are; if we are changing the climate, what sort of climate can we expect in the future? How much will the temperature rise? How much will sea-level rise? Prospects for our own future depend on how well we can answer these questions. In order to comprehend the causes of and the variability of such expected changes, it is helpful to gauge the rate and magnitude of such changes in the past.

Instrumental temperature records extend back to the early $1700 \mathrm{~s}$, long enough to indicate trends from pre-industrial times, but not for the earth's response to lower greenhouse gas levels in the last ice age 20,000 years ago. Historical records have only limited value for this purpose, being spatially and temporally fragmented and largely non-numerical. However, useful climate data can be extracted from ice and sediment, which have accumulated in various parts of the world through the last glacial cycle, when the climate switched from a warm interglacial to cold glacial conditions and back again in about 120,000 years. The last glacial cycle is a period of particular interest, as ice sheets waxed and waned resulting in large changes in temperature, precipitation, atmospheric chemistry, sea level and a variety of other climate indicators.

Arguably the most significant factor in forcing climate during glacialinterglacial cycles of the Quaternary has been the greenhouse gas content of the atmosphere (Bradley 1999). To understand what causes changes of this scale, similar to those already brought about by human activity (IPCC $4^{\text {th }}$ assessment 2007), we need to know how much carbon is stored and cycled between the atmosphere and the marine and terrestrial biospheres through time. A major component in calculating 
these changes is an estimate of how much carbon is stored in the terrestrial biosphere at any given time. Considerable disagreement exists between current estimates from marine and terrestrial records of the last glacial cycles. Much of this variance relates to "the missing" atmospheric $\mathrm{CO}_{2}$ when concentrations were lower during colder glacial conditions during the last glacial cycle. Calculations from the marine isotope record, based on differences between $\delta^{13} \mathrm{C}$ from planktonic and benthic foraminifera, suggest a movement of 500 Gigatonnes $(\mathrm{GtC})$ of carbon from the land to the ocean (Shackleton 1977, 1992). However, calculations based on pollen records of paleovegetation distributions, range from 700 to $1700 \mathrm{GtC}$ (Crowley 1995, Adams and Faure 1998 and Otto et al. 2002).

Changes in the amount of terrestrial carbon can also be estimated from the proportion of $\delta^{13} \mathrm{C}$ in atmospheric $\mathrm{CO}_{2}$ through time using proxy data. Climate proxy data by definition is "any climate dependant natural phenomena which incorporate into their structure a measure of this dependency" (Bradley 1999). As an example, the $\delta^{13} \mathrm{C}$ value of atmosphere can be used to estimate how much vegetation is on the surface of the earth at any given time. Plants discriminate against ${ }^{13} \mathrm{C}$ when absorbing $\mathrm{CO}_{2}$ from the atmosphere (Farquhar et al. 1982). Hence, when global vegetation levels are high, atmospheric ${ }^{13} \mathrm{C}$ levels are high, and conversely, when global vegetation levels are low, atmospheric ${ }^{13} \mathrm{C}$ levels are low. While we have very good record of changes in bulk concentration of atmospheric carbon dioxide through the last glacial cycle from the analysis of air bubbles trapped in polar ice (e.g. Petit et al. 1999), these records are unable to define changes in the carbon isotope ratios for the same period. At present there are a number of temporally limited, or lowresolution, chemically compromised records (Friedli et al. 1986, Fisher et al. 1999, Indermuhle et al. 1999, Smith et al. 1999, Trudinger et al. 1999). A new technique devised by Ferretti et al. (2000) to isotopically analyse small air samples has been used on Antarctic ice core samples, and first results look promising (Leuenberger et al. 2000). However, at present a last glacial cycle record of atmospheric carbon isotope ratios from ice cores remains unavailable.

To measure changes in ${ }^{13} \mathrm{C}$ of atmospheric carbon dioxide through longer periods of time, a new method has been developed and presented in this thesis. The method is based on the measurement of ${ }^{13} \mathrm{C}$ in carbon trapped in ancient phytoliths 
(silica precipitated in plants, Fig. 1.1) and conversion of this signal into an atmospheric carbon record of the atmosphere.

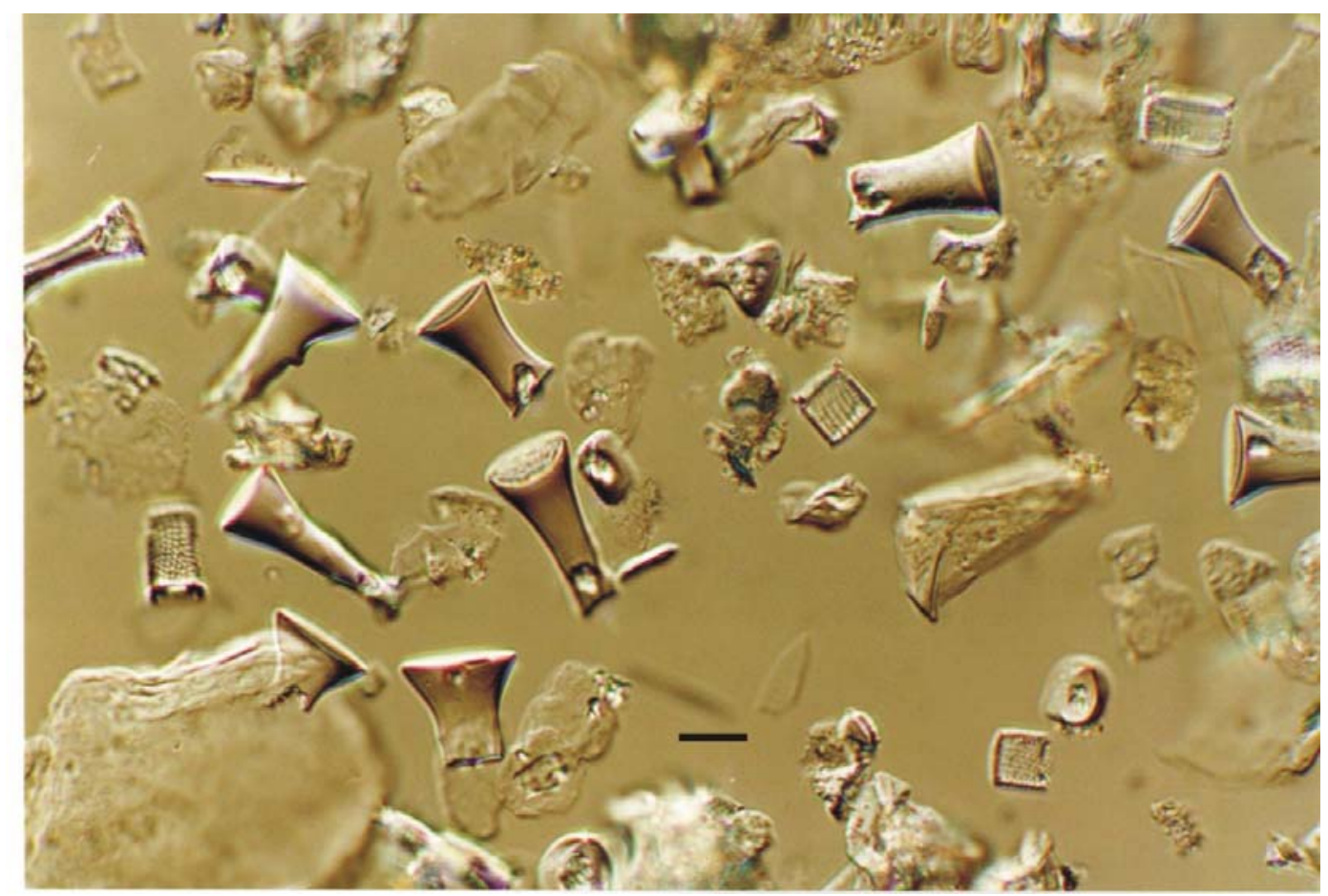

Fig. 1.1: A photomicrograph showing a typical grassland phytolith assemblage extracted from a loess sample from South Wairarapa (Scale bar $10 \mu$ ).

When phytoliths form, some of the organic host material is trapped inside them (Piperno 1988, 2006, Carter 2007). Moreover, because phytoliths survive well in most soils and sediments, this carbon is well preserved and yields a record of $\delta^{13} \mathrm{C}$, which can then be used to answer the question of how much $\mathrm{CO}_{2}$ was sequestered on land during the last glacial cycle.

\subsection{The Purpose and Scope of this Thesis}

The main purpose of this research is to derive an ancient atmospheric $\delta^{13} \mathrm{C}$ signal from phytolith-occluded carbon. The project was conducted in three stages:

1) morphological assemblages of phytoliths were extracted from a loess sequence at Otaraia in the Wairarapa Valley, New Zealand (Fig. 1.2) and used to 
describe vegetation changes in the area through the last interglacial- glacial cycle (Chapter 2),

2) reference values for carbon isotope signatures of phytoliths from a range of modern plants were determined (Chapter 3), and

3) carbon isotopic ratios were measured on a set of phytoliths extracted from the same loess samples and a 125,000 year global atmospheric $\delta^{13} \mathrm{C}$ record was determined (Chapter 4).

Before analysing ancient phytolith-occluded carbon it was thought important to scope the natural variability in modern plant species, and identify processes that might cause differences between the ${ }^{13} \mathrm{C}$ value between atmospheric carbon and that trapped in contemporaneous phytoliths. These processes include fractionation effects between the atmosphere and plant material and between plant material and phytolithoccluded carbon. An effort was also made to determine the carbon compounds present in the occluded carbon (Chapter 3). Plants photosynthesising carbon from atmospheric $\mathrm{CO}_{2}$ discriminate against the stable carbon 13 isotope. This results in the stable carbon isotopic ratio $\left({ }^{13} \mathrm{C} /{ }^{12} \mathrm{C}\right)$ of plant material being significantly different than the corresponding isotopic ratio of atmospheric carbon dioxide (Farquhar et al. 1982).

A number of modern plants were sampled to establish the relationship of the carbon isotopic ratios between plant leaves and phytolith-occluded carbon extracted from the same leaves. Plant species chosen were those providing the most common phytoliths extracted from the Otaraia core, and those representing the dominant species for the likely range of environments during a glacial cycle in the southern Wairarapa.

\subsection{Field Location and Sampling of the Otaraia Loess Section}

Previous studies demonstrated that loess deposits in the Wairarapa Valley contain numerous well-preserved phytoliths (Carter and Lian 2000, Carter 2000). The Otaraia loess core is one of a series of four cores collected in Wairarapa Valley in the early 1980's by Palmer (1982). It was drilled in a field approximately $20 \mathrm{~m}$ east of the Martinborough-Lake Ferry Road on the lower north-slope of the Aorangi range in the lower Wairarapa Valley (NZMS Grid reference S27 056886). 
The core was sampled every $10 \mathrm{~cm}$ with two sub-samples taken at each level. One sample was used to extract phytoliths for morphological analysis and provide an assessment of paleoenvironmental conditions in the Wairarapa through the last interglacial- glacial cycle through the analysis of assemblage morphologies. The second sample provided phytoliths whose occluded carbon yielded a $\delta^{13} \mathrm{C}$ signal reflecting global atmospheric carbon composition. An age model for the loess section was constructed from a prominent and well-dated tephra marker bed and three optically stimulated luminescence (OSL) ages. 


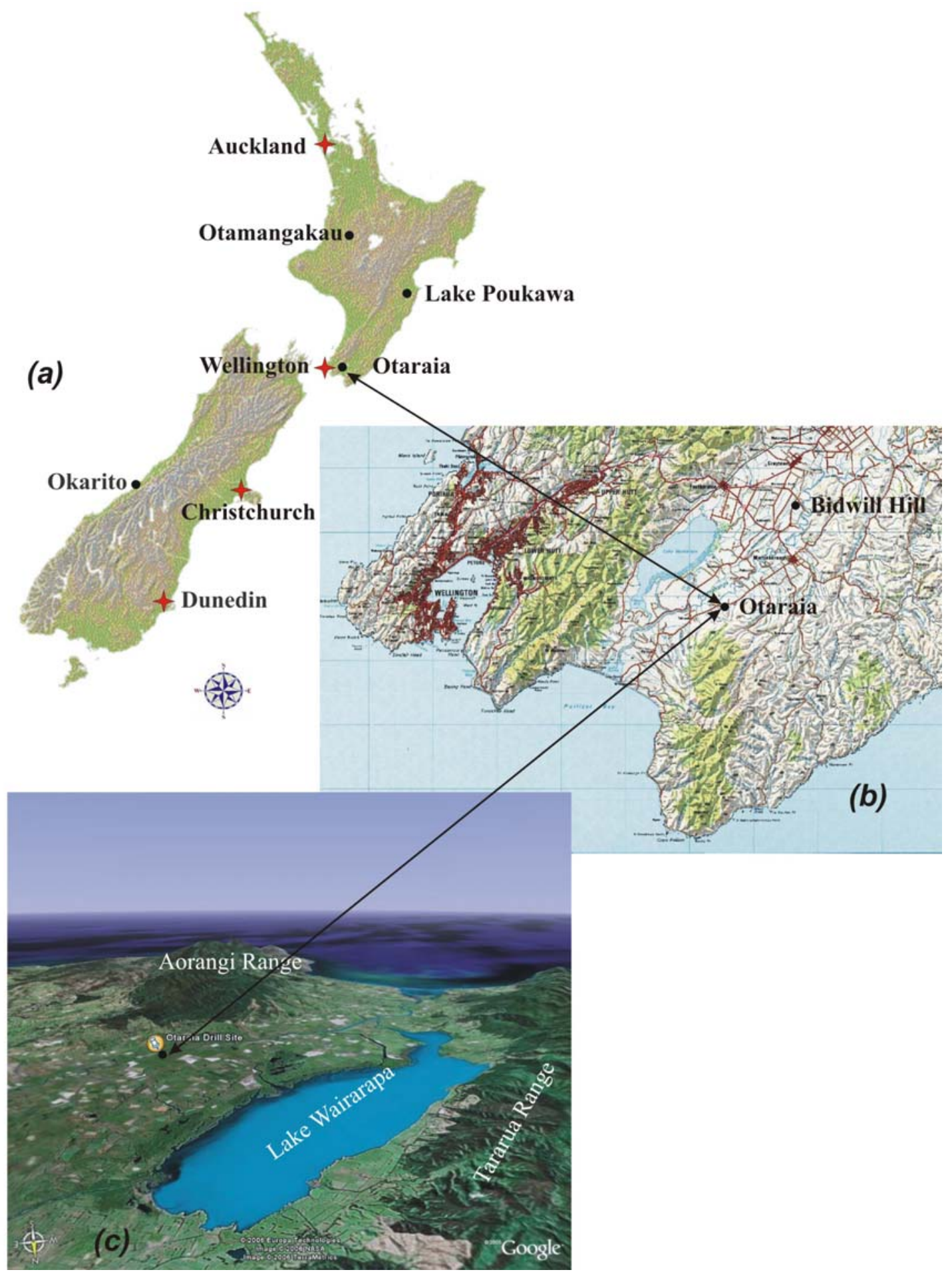

Fig. 1.2: Location of Otaraia drill site on a (a) map of New Zealand, (b) map of the southern North Island, and (c) an oblique view of the south Wairarapa looking south. This shows the relationship between the drill site, the Aorangi Mountains, Lake Wairarapa and Palliser Bay. (Geographx Ltd., Google Earth, Metamedia Ltd.) 


\subsection{A Brief History of Phytoliths}

Phytoliths, as noted above, form within most plants. They are also termed silica phytoliths, opal phytoliths, plant opal, biogenic opal and silica cells, but for this study, the term "phytolith" will suffice. This term, which is from Greek meaning "plant stone", can refer to all mineralised particles found in plants. However, it is most frequently used for the silica particles formed within plants. Phytoliths form distinctive shapes that can be recognised again and again. They also survive well in most soils and sediments. Historically, phytoliths have been documented in the scientific literature since the mid-nineteenth century. In 1854, the German natural historian Ehrenberg published illustrations of phytoliths in his seminal textbook Microgeologie. However, it was not until the second half of the twentieth century that phytolith analysis was applied extensively in paleoenvironmental and archaeological research. During the last decade, new analytical methods and techniques have been developed, improving the utility of phytolith analysis, especially for Quaternary sediments. In addition, the discovery that carbon is occluded during phytolith formation has increased the scope of phytolith research. This characteristic makes them a particularly useful source of information in the reconstruction of past environments and climates, as well as ancient human migration, and early exploitation and cultivation of plants, and radiocarbon dating.

\subsection{Phytolith Formation}

Phytoliths are formed from silica carried up from groundwater. The weathering of silicate minerals at the earth's surface provides large amounts of soluble silica, some of which is absorbed by growing plants. In solution silica exists as monosilicic acid $\left(\mathrm{H}_{4} \mathrm{SiO}_{4}\right)$ with $\mathrm{pH}$ values of between 2 and 9. It is carried upward in the vascular system and becomes concentrated during transpiration around the leaf stomata. The supersaturated solution begins to polymerize or gel, then solidifies and forms solid opaline silica $\left(\mathrm{SiO}_{2}: \mathrm{nH}_{2} \mathrm{O}\right)$ bodies (phytoliths) within and between some of the plant cells. The relationship between transpiration and deposition of phytoliths remains poorly understood. However, it has recently been discovered that phytolith formation in Cucurbita fruits is largely genetically determined (Piperno 2002). Grasses are probably the most widely distributed plants on earth, and produce many 
and varied phytoliths. The first documented phytoliths were those from grasses, and for many years the most extensively studied (Twiss 2001)

More recently phytoliths have been extracted and described from pteridophytes (ferns Fig. 1.3), gymnosperms and angiosperms throughout the world. Nevertheless, it should be noted that some plants produce few or no recognisable phytoliths (e.g. Pinaceae) and the reason for this is not clear (Piperno 1988).

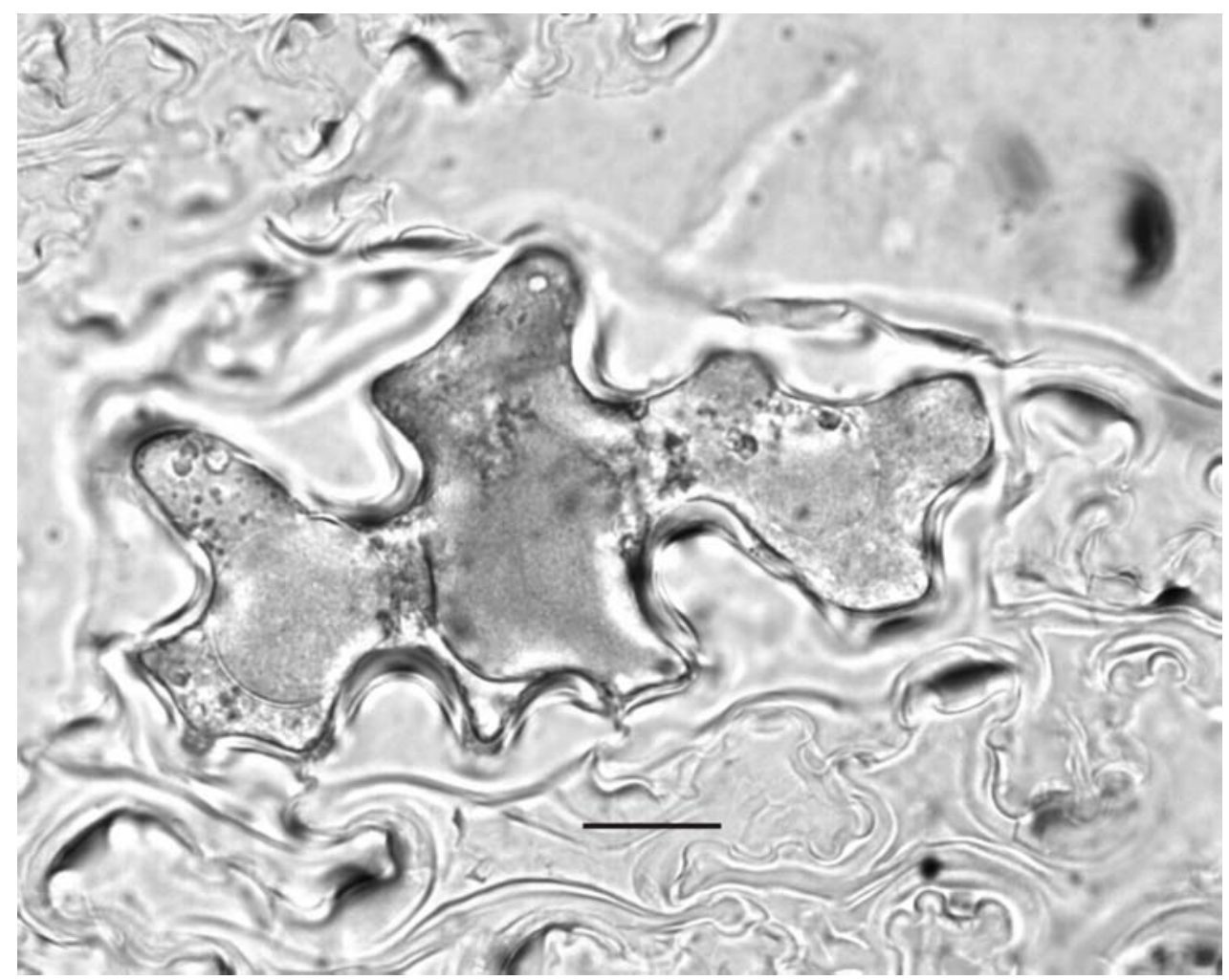

Fig 1.3 Photo-micrograph of an anticlinal phytolith from a modern fern Blechnum sp. (Scale bar $20 \mu$ )

Phytoliths are found in nearly all plant structures; stems, leaves, roots, and inflorescences. In general, more phytoliths form in the above ground tissue than below, but in some plants phytoliths are equally spread throughout. Patterns of phytolith formation appear to be consistent within families and species, but only a fraction of the global flora has been investigated for the presence of phytoliths. The formation of in monocotyledons often involves the filling of a cell interior. Cell interiors act as moulds, producing solid phytoliths of different but repeatable three dimensional shapes. 
Grass phytoliths tend to be more robust than the plate-like forms produced in great numbers by many tree and fern species because of their squat forms. This makes them extremely resistant to decomposition and are therefore, more frequently recovered from soils and sediments than those produced by woody and fern species. One problem in the interpretation of phytoliths from trees, shrubs and ferns has been the poor preservation of the most common phytoliths, anticlinal in ferns (Fig. 1.3) and polyhedral in trees and shrubs (Fig. 1.4) produced in the epidermal cell walls of leaves of these plants. These phytoliths are poorly preserved because of their fragile plate-like structures, which tend to become fragmented and broken in sedimentary deposits.

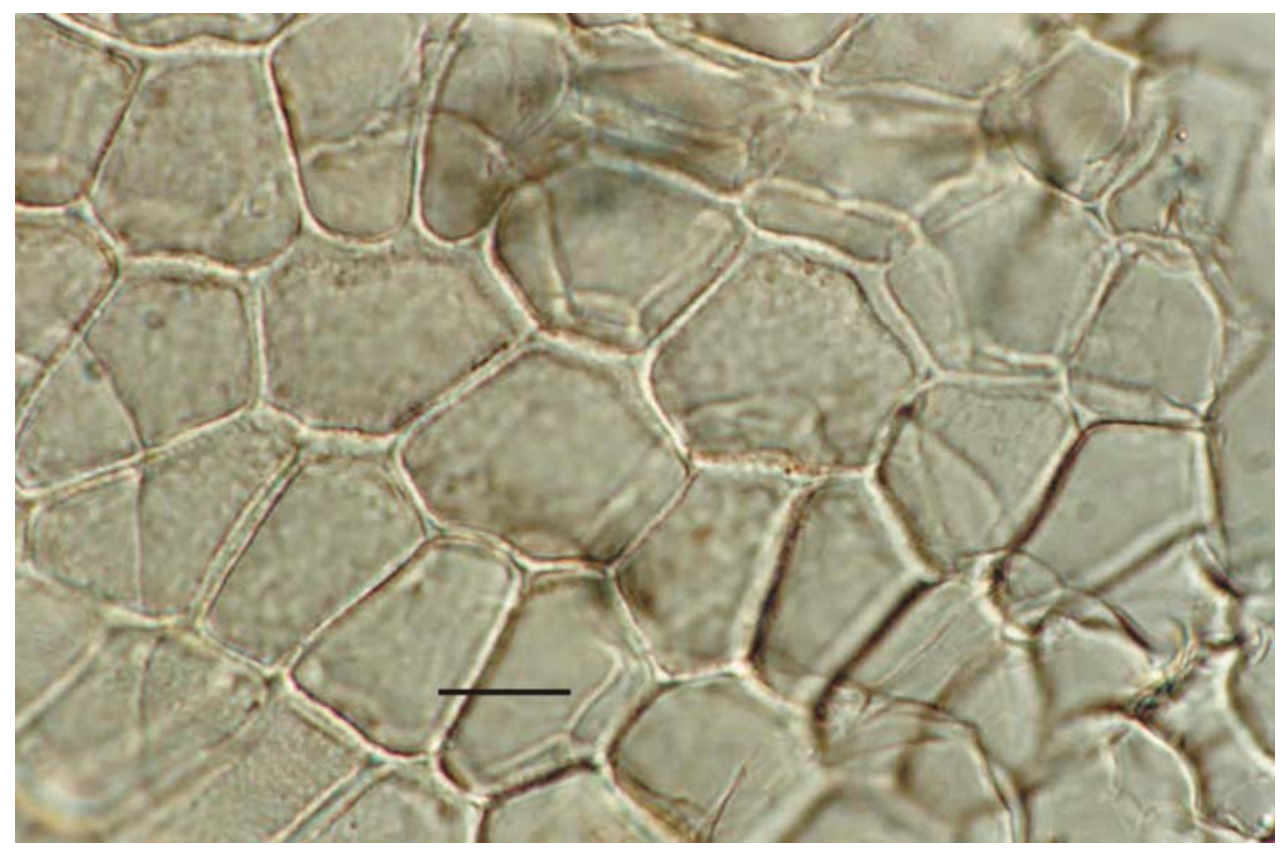

Fig. 1.4: Fragile (polyhedral) tree phytoliths from modern plant (Nothofagus solandri var solandri). (Scale bar $20 \mu$ )

However, the paucity of the plate-like cells preserved in sediments tends to be countered by the very good preservation of globular phytoliths (Fig. 1.5), which are produced in large numbers in the centre of groups of silicified epidermal cells of trees and shrubs (Bozarth 1992). 


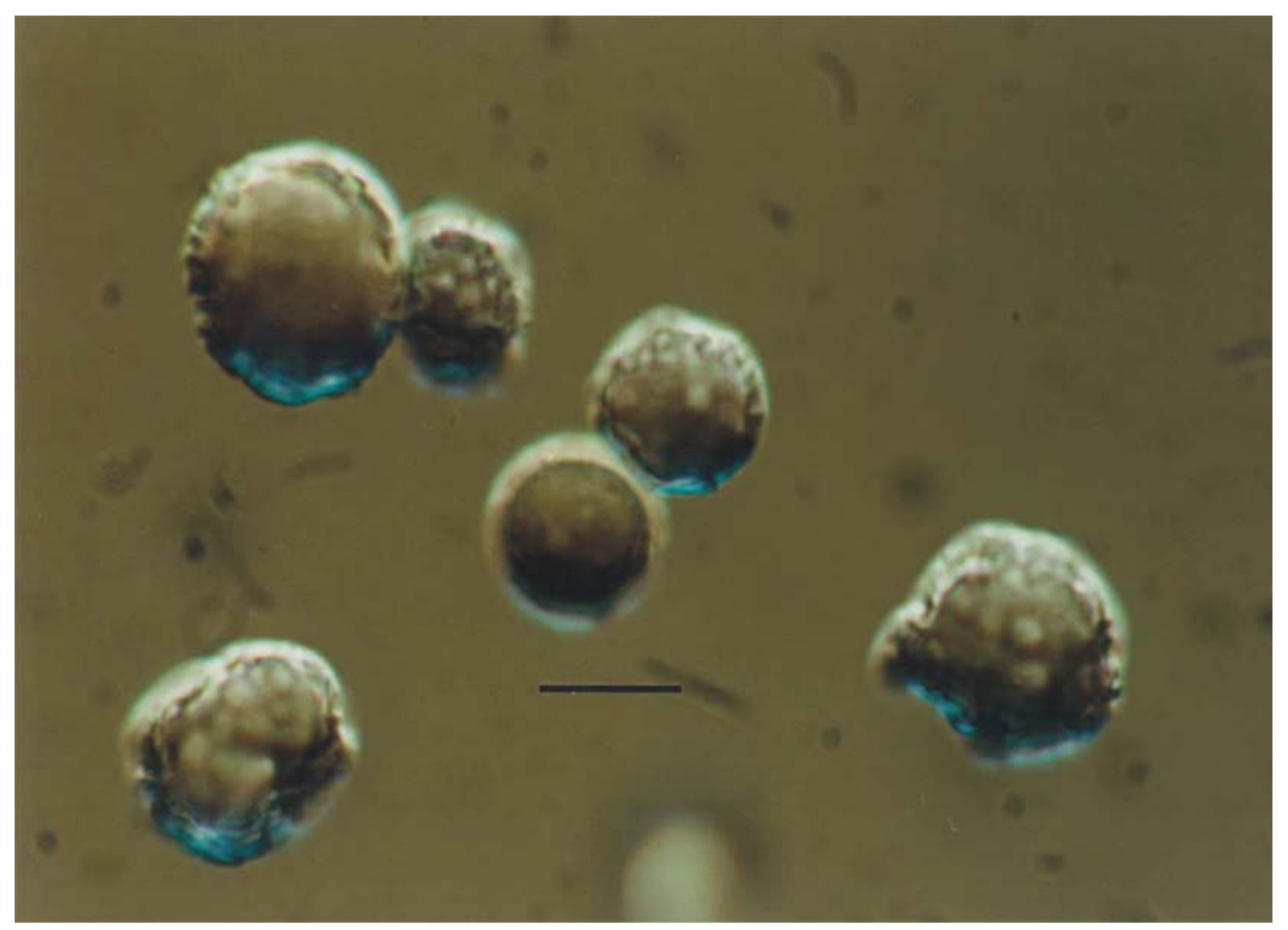

Fig. 1.5: Globular tree phytoliths from modern native New Zealand tree species Knightia excelsa). The scale bar $=10$ micron.

\subsection{Composition, Characteristics and Function}

Phytoliths are largely composed of amorphous (noncrystalline) silicon dioxide $\left(\mathrm{SiO}_{2}\right)$ and about 4 to $9 \%$ water. However, measurable amounts of microcrystalline $\mathrm{SiO}_{2}$ have been reported within phytoliths, offering the prospect of direct dating using optically stimulated luminescence (OSL) methods (Rowlett and Pearsall 1993). Phytoliths are optically isotropic with refractive indexes of between 1.41 to 1.47 and a specific gravity range of 1.5 to 2.3 . They range in colour under transmitted light from colourless to light brown to opaque. Phytoliths can also contain significant amounts of occluded, chemisorbed or solid solution impurities such $\mathrm{Al}, \mathrm{Fe}, \mathrm{Ti}, \mathrm{Mn}, \mathrm{P}, \mathrm{Cu}, \mathrm{N}$, and $\mathrm{C}$. It is thought that the presence of carbon within phytoliths is the result of the trapping of plant cellular material during phytolith formation within living cells. In addition, it has been demonstrated that more than $50 \%$ of this encapsulated carbon is protected from oxidation, and thus provides another source of paleoenvironmental and paleoclimatic information (Kelly et al. 
1991). The development of accelerator mass spectrometry (AMS) radiocarbon techniques using very small samples allows for the dating of phytolith carbon (Mulholland and Prior 1993). Moreover, carbon isotope analysis can also be used to provide additional information about the photosynthetic pathway of plants. For example, knowledge as to whether $\mathrm{C} 3$ and $\mathrm{C} 4$ grasses dominated a given environment is an indication of climate at the time those plants were growing (Smith and Anderson 2001 and Smith and White 2004). Carbon isotope analysis of phytolith-occluded carbon is used in this study to generate a late Quaternary isotopic record of atmospheric carbon dioxide. In addition to providing generalised patterns of vegetation history from the analysis of phytolith morphologies, phytoliths are unique in being directly dateable and providing evidence of changes in the ratios of atmospheric $\mathrm{CO}_{2}$, from the same material. Moreover, because phytolith-occluded carbon is of plant cellular origin, it is theoretically possible that DNA is present and could provide direct evidence of the species of origin. At present at least one group of researchers is developing methods to extract and analyse DNA from phytolithoccluded carbon (Alan Cooper, University of Adelaide pers. com).

The functional significance of silica is not obvious. To some extent the mechanism of phytolith formation appears passive and they represent no more than "waste products". However, phytoliths provide mechanical compression-resisting support, preventing the collapse of cell walls under tension during transpiration. Moreover, phytoliths provide plants with increased resistance to browsing by herbivores and insects, and attack by pathogenic fungi. Research has also shown that in some situations plants are actively incorporating solid silica into their structures. In spite of incomplete understanding as to why some plants secrete silica and others do not, it does appear that silica is an essential element in the development of some species (Piperno 1988, 2006).

\subsection{Form and Preservation}

At the heart of phytolith analysis is an understanding of how the shapes of phytoliths extracted from sediments and seen under a microscope can be related to the species or family of plants in which they formed. Phytolith analysis is a relatively 
young discipline and as a result there is an issue in linking a particular phytolith form to a plant from which it originated. These are of two types:

1) "multiplicity", when many different phytoliths are found in a single taxon, and

2) "redundancy", when the same form can occur in many taxa.

Another problem is associated with lack of representation of some phytolith forms in assemblages extracted from sediments. As mentioned above, some phytoliths produced by plants do not persist or are poorly represented in sediments and soils. However, these problems are being resolved as more reference collections of modern phytoliths and soil assemblages are compiled. One such example is the reference collection produced by Wallis (2003) who documented the occurrence of distinctive phytoliths from the leaves of 177 non-grass plant species from northwest Australia. The study showed that although only $50 \%$ of the specimens examined yielded sufficient phytoliths, these had enough morphological variability to distinguish between fossil phytolith assemblages from the region.

\subsection{Terminology and Classification}

Historically, the terminology and classification used to describe phytoliths have been of a fragmented and individual nature. Over the last 30 years individual researchers have constructed a number of independent phytolith identification schemes, which were used to deal with phytoliths extracted from plants or sediments from a specific region. There was a certain amount of overlap between these schemes and over the last few decades a number of attempts have been made to develop a universally accepted standard phytolith classification scheme (Rapp and Mullholland 1992, Bowdery et al. 2001). However, it was not until the 3rd International Meeting on Phytolith Research (IMPR) in Bruxelles, in August, 2000, that a working group was formed to develop agreed standards and to harmonize the naming and description of phytoliths. This group has now reported with the "International Code for Phytolith Nomenclature 1.0 (Madella et.al. 2005)". Some approved terms are illustrated in figure 1.6. 
The core of the code lies in the proposal that the name for a particular phytolith type should be formed by a maximum of up to three descriptors, the first of which should be the two or three-dimensional shape. The second descriptor should be texture and/or ornamentation and should be added if this is characteristic or diagnostic. A third descriptor can be added when the anatomical origin is clear and beyond doubt. For example, "bulliform" is an established botanical term to describe a particular type of cell found in grass leaf epidermis. For this particular case, the word conveys both an anatomical and a descriptive meaning. The proposers foresee that as experience with the scheme grows and the range of phytolith types expands, it will require some revision. 


\begin{tabular}{|c|c|c|}
\hline Schematic drawings* & ICPN names & Former nicknames \\
\hline & $\begin{array}{l}\text { Bilobate } \\
\text { short cell }\end{array}$ & $\begin{array}{l}\text { Dumbbell or } \\
\text { bilobate }\end{array}$ \\
\hline & $\begin{array}{l}\text { Trapeziform } \\
\text { short cell }\end{array}$ & $\begin{array}{l}\text { Square or } \\
\text { rectangle }\end{array}$ \\
\hline & $\begin{array}{l}\text { Cylindrical } \\
\text { polylobate }\end{array}$ & Polylobate \\
\hline & $\begin{array}{l}\text { Trapeziform } \\
\text { polylobate }\end{array}$ & Polylobate \\
\hline & $\begin{array}{l}\text { Elongate echinate } \\
\text { long cell }\end{array}$ & $\begin{array}{l}\text { Elongate spiny or } \\
\text { elongate sinuous }\end{array}$ \\
\hline & $\begin{array}{l}\text { Cuneiform } \\
\text { bulliform cell }\end{array}$ & $\begin{array}{l}\text { Bulliform or } \\
\text { fan-shaped }\end{array}$ \\
\hline & $\begin{array}{l}\text { Parallepipedal } \\
\text { bulliform cell }\end{array}$ & Bulliform \\
\hline 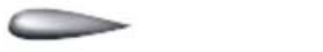 & Acicular hair cell & Point-shaped \\
\hline & $\begin{array}{l}\text { Unciform hair cell } \\
\text { Globular granulate }\end{array}$ & $\begin{array}{l}\text { Point-shaped } \\
\text { Spherical rugose }\end{array}$ \\
\hline & Globular echinate & Spherical crenate \\
\hline & $\begin{array}{l}\text { Cylindric sulcate } \\
\text { tracheid }\end{array}$ & Tracheid \\
\hline
\end{tabular}

*Several drawings are made after Fredlund and Tieszen (1994).

Fig. 1.6: Internationally defined morphological phytolith shapes from the International Code for Phytolith Nomenclature 1.0 (Madella et.al. 2005). 


\subsection{Paleoenvironmental Reconstruction}

Phytoliths have been used to reconstruct paleoenvironments in all continents and most regions throughout the world (Piperno 2006). Because phytoliths are made of silica, they are resistant to decomposition in most environments, and therefore, are particularly useful in situations where there is paucity of alternative climate and environmental proxies, e.g. arid environments. They are also useful in overcoming the problem associated with identifying grasses from pollen in ancient sediments. It is very difficult to distinguish between pollen produced by different grass species (Bill McLea, Victoria University of Wellington, pers. com). In contrast, phytoliths have proved very useful in determining the composition of paleoenvironments dominated by grasses. Some examples of recent studies follow to briefly illustrate the possible geographic and climatic range of phytolith research.

In New Zealand, Carter and Lian (2000) used variations in phytolith assemblages extracted from a well dated $6.4 \mathrm{~m}$ loess core to infer in the relative abundance of forest and grass cover in the southern Wairarapa over the last 120,000 years (Fig. 1.7). The sediments showed pollen and diatoms for only about the first metre, in contrast to numerous and very well preserved phytoliths in all samples. The record showed an association between the tree-shrub phytolith fluctuations and the "warm" peaks of the oxygen isotope curve of Martinson et al. (1987) between Marine Oxygen Isotope Stages (MIS) 1 and 5, suggesting that changes in the ratio of arboreal to non-arboreal phytoliths directly result from changes in climate. 


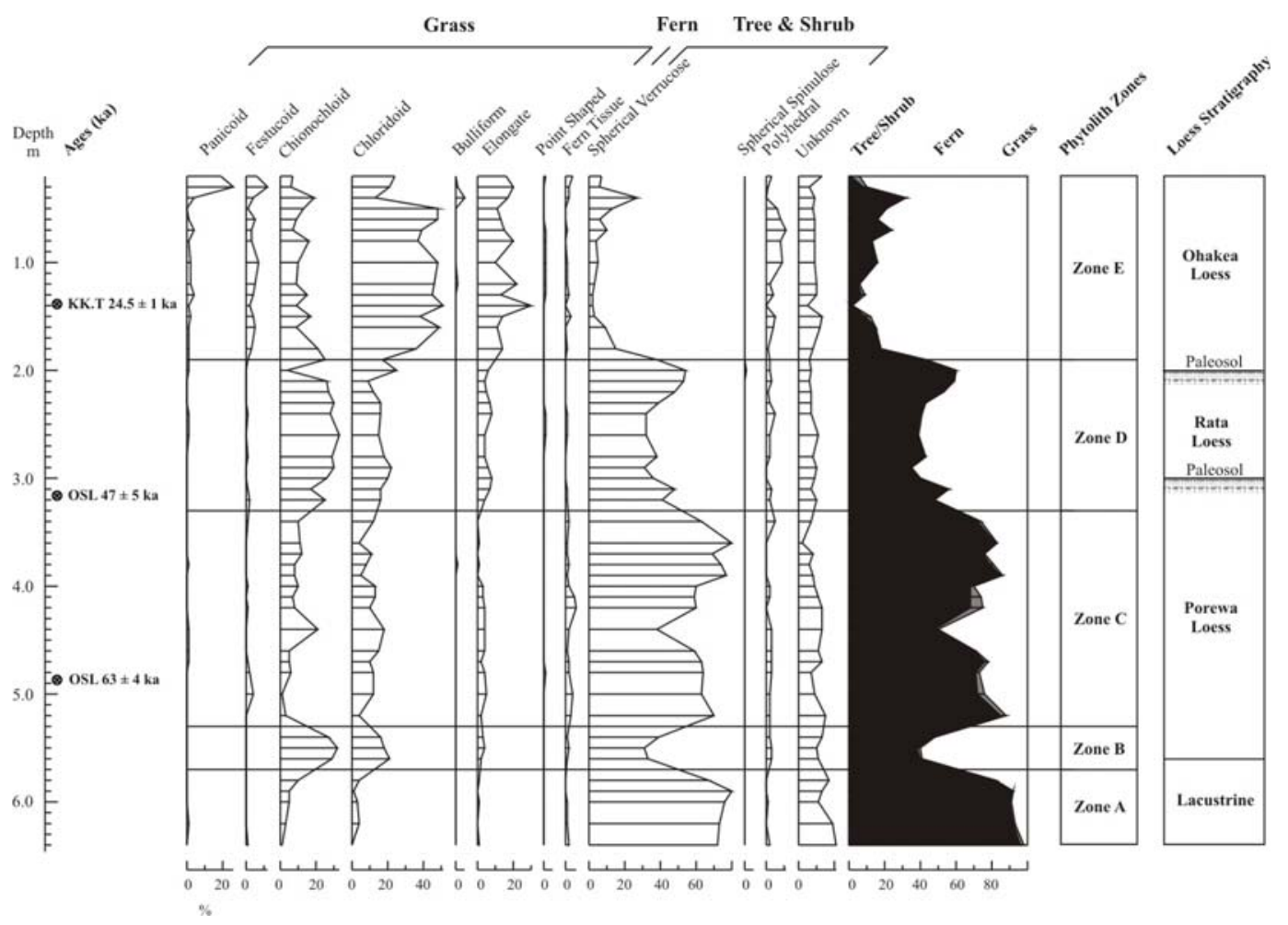

Fig. 1.7: Diagram showing the changes in phytolith assemblages through a $6.4 \mathrm{~m}$ loess core from Bidwill Hill, Wairarapa, New Zealand (Carter and Lian 2000).

In North America, Fredlund and Tieszen (1994) showed that morphological analysis of phytoliths could distinguish between the tall and short grassland formations growing on the Great Plains. Moreover, by isotopically analysing the phytolith-occluded carbon derived from these grasses they were able to quantify the proportions of C3 and C4 grasses through time. Subsequently, Blinnikov et al. (2001, 2002) analysed grass phytoliths extracted from a 100,000-year old loess deposit, in the state of Washington, USA, to provide an estimate of the range of temperature differences through time, confirming that the later stages of the last glacial were colder and drier there than today.

Phytoliths can also record changes in precipitation, as Alexendre et al. (1997) found from sediments in Lake Guiers in Senegal Northwest Africa. There the phytolith record shows that the surrounding vegetation changed from tall grass savannah woodland into a short grass savannah, indicating that the region became drier between 4000 and $1200 \mathrm{yr}$ BP. 
There have also been many phytolith-derived paleoenvironmental reconstructions from Asia. One example is the work of Sase and Hosono (2001), who analysed phytoliths from a last interglacial series of soils from northern Japan. The volcanic soils of the area were extremely acidic and hence were poor in organic fossils such as pollen, wood and snails, but rich in phytoliths. Sase and Hosono (2001) were able to show that the vegetation and climate as indicated by the phytolith records, changed in correspondence with the Glacial- Interglacial cycle and the marine oxygen stages of Martinson et al. (1987).

The last decade has seen much progress in exploiting the rich variety of information contained within these well preserved microfossils. These include the development of statistical methods, as well as chemical, and isotopic microanalytical methods. For example, in order to establish a more quantifiable relationship between vegetation and phytolith assemblages, various statistical quantitative methods have been applied, such as constrained classification techniques; cluster analysis and correspondence analysis (see reviews of phytolith statistical methods in Pearsall and Piperno 1993, Pearsall 2000 and Piperno 2006). To find the most suitable statistical methods for phytolith analysis Powers-Jones and Padmore (1993) compared a number of methodologies. Fredlund and Tieszen (1997) used modern phytolith data to develop a climate transfer function, which quantified temperature and precipitation values from late Pleistocene phytoliths of the North American Plains. Bobrov et al. (2001) were able to demonstrate that cluster and canonical correspondence techniques distinguished between phytoliths from 69 cyperaceae and gramineae species in Russia. A transfer function technique was also used to quantify the relationship between modern phytolith assemblages and environmental parameters in a late Quaternary paleoenvironmental record from Taieri Plain, Otago, New Zealand. Prebble et al. (2002) showed that there was close correlation between elongate phytoliths and $\mathrm{pH}$, bilobate and average annual precipitation, trapeziform and log conductivity, and globular and average autumn temperature. The technique was applied to the phytolith assemblages from the core and showed that precipitation increased in the Holocene between 11,000 to 6,000 years ago, which was followed by a decline in precipitation from 6,000 years ago until the present (Prebble et al. $2002)$. 


\subsection{Chronology}

An important aspect of late Quaternary research is to provide reliable ages for the stratigraphic record. Most phytolith studies take place in an established stratigraphic framework, whether from a sequence of soil deposits, loess sections, alluvial strata, lake sediments or marine cores. Ages for those from the last glacial cycle - the last 120,000 years or so - typically depend on ${ }^{14} \mathrm{C}$ ages for the portion younger than $\sim 40,000$ years. Ages for older strata can be estimated assuming sediment accumulation rates for older strata were the same as for younger strata. However, it is plainly desirable that these be "pinned" by independently dated material from the section - eg U-series ages from shell, luminescence ages from quartz, or radiometric ages from volcanic ash.

Occluded carbon is ubiquitous in phytoliths and is sealed against postdepositional contamination. Thus, it is ideal for ${ }^{14} \mathrm{C}$ dating, though the amount is small (typically $14 \mathrm{mg}$ ). Wilding (1967) was the first to determine a radiocarbon age from phytolith-occluded carbon. However, because of the large amount of sample needed (45 kg of sediment) it was impractical for most applications. The development of Accelerator Mass Spectroscopy (AMS) has made possible the dating of carbon samples as small as 100 microgram $(\mu \mathrm{g})$ (Christine Prior, GNS pers com.). As with most new techniques, a number of issues have been raised with regard to preparation, accuracy and reliability. These are that the phytolith ${ }^{14} \mathrm{C}$ appear to be too young, and are inconsistent with the stratigraphy. Therefore, the technique is in the process of being further developed and tested (Prior et al. 2005).

Luminescence dating has recently become possible with the recognition that phytoliths contain microcrystal structures within a matrix of amorphous silica. Theoretically, these microcrystalline structures should be able to trap electrons and as such be amenable to thermoluminescence (TL) dating. Rowlett and Pearsall (1993) examined the feasibility of TL dating of phytoliths. They dated a number from sediments associated with ceramics of known cultural affiliation and radiocarbon-dated organic material. While their TL dates were in general agreement with the previously accepted ages, indicating its potential, the phytolith matrix was shown to be unstable at high temperatures. 
More recently Rieser et al. (2005) have measured strong luminescent light emission from phytoliths following both infrared and green light stimulation using the optically stimulated luminescence (OSL) method. This team is continuing with experiments to refine the technique, and is using both $\mathrm{AMS}{ }^{14} \mathrm{C}$ and OSL techniques to date the same phytolith material to establish the reliability of OSL dating of phytoliths. OSL techniques allow strata to be dated routinely back to around 200,000 years, a significant advantage over the ${ }^{14} \mathrm{C}$ method.

\subsection{Advances in Chemical Analysis}

In recent years it has become possible to analyse the chemistry of phytoliths and their occlusions from microgram samples with an accuracy of parts per billion following the development of new instruments such as the inductively coupled plasma source mass spectrometer (ICP/MS). Hart (2001) used this technique to examine and document trace elements present within phytoliths from the leaves of Actinotis helanthi and Triodia mitchelli, and was able to confirm the presence of more than double the previously documented number of trace elements in phytoliths and their occlusions. Smith and Anderson (2001) used another pair of techniques, Tetramethylammonium (TMAH) thermochemolysis and gas chromatography-mass spectrometry (GC-MS), to characterise the organic compounds in $\mathrm{C} 3$ and $\mathrm{C} 4$ phytoliths (more details in next section).

To improve on phytolith taxonomic resolution, Carnelli et al. (2002) proposed a new method of distinguishing between similar morphological forms from different taxa. Using X-ray analysis paired with phytolith morphology they have been able to demonstrate that the proportion of aluminium in phytoliths from Ericaceae and conifers was significantly higher than in Cyperaceae and Gramineae. The technique will require further investigation of different taxa to confirm that the co-deposition of $\mathrm{Al}$ and $\mathrm{Si}$ in phytoliths is more frequent in woody plants than herbaceous plants. However, if proven, this has a number of possible applications, including reducing uncertainty arising from production of the same phytolith morphotypes in different taxa. This method could also be used in the investigation of past shifts in herbaceous and woody vegetation produced as a result of climatic variation and/or human activity. 


\subsection{Phytoliths in Archaeological Research}

The Quaternary is the time period that saw the latter part of the evolution of hominids, and as a consequence there is considerable overlap between the disciplines of anthropology, archaeology and Quaternary geology. The evolution of Homo sapiens from earlier hominids was followed by migration out of Africa into Asia, Europe, and the Americas (Stringer and McKie 1996). As the climate warmed following the last glacial period, humans began experiments in cultivating wild grasses leading to the development of agriculture and the consequence was the rise of a number of independent civilisations (Fernandez-Armesto 2000).

Phytoliths have been found to be particularly useful in documenting the early domestication of wheat (Triticum spp.), barley (Hordeum spp.), millet (Panicum spp.), rice (Oryza satvia) and maize (Zea mays). Phytolith morphometric methods are used to distinguish between these domestic crops and their wild ancestors, allowing for a more accurate timing of the onset of agriculture. Presence of these and other phytoliths in ancient sedimentary deposits has been used for charting the human development of agriculture and landscape change over the last 10,000 years in a number of independent centres, including North and South America. Accordingly, phytolith analysis is used extensively in archaeology, with particular respect to the early exploitation and development of grain crops (Meunier and Colin 2001). Asian rice Oryza satvia L. (var. japonica) was domesticated in the middle Yangtze River Valley of southern China shortly after 10,000 years ago. Distinctive phytolith morphological differences between wild and domesticated Oryza species are particularly suitable in documenting change from early exploitation of a wild resource and its subsequent cultivation (Zhao and Piperno 2000). Rosen and Weiner (1994) were able to show that wheat (Triticum spp.) and barley (Hordeum spp.) grown with irrigation in semi-arid plots produced phytoliths with greater numbers of silicified cells per phytolith, than those grown under dry farming conditions. They have demonstrated that the presence of large multi-celled phytoliths in semi-arid archaeological site provides evidence of pre-historic irrigation. More recently Lu et al. (2005) used a combination of phytolith and pollen evidence to show that noodles were being made in north-western China about 4,000 years ago. They discovered a well preserved and sealed earthenware bowl discovered at a Late Neolithic 
archaeological site. Inside they found noodle remains and seed-husk phytoliths and starch grains indicative of ground millet (Panicum spp.).

Analysis of phytoliths from sediments has also proved useful in describing

the early cultivation of non-grain crops such as banana and taro. Hybridization of bananas has resulted in a near sterile plant, and as such produces little or no seed. However, it does produce distinctive phytoliths and starch, which have been extracted from pre-historic sediments and used to document the deliberate planting of taro (Colocasia esculenta) and banana (Musa spp.), this demonstrates that agriculture arose independently in New Guinea between 6950 to 6440 years before present (Denham et al. 2003). One of the more interesting questions regarding the domestication of Musa is how and when it got to Africa. No wild Musa has ever been reported in the natural state in Africa. Therefore, it is believed to have been deliberately introduced by humans. Musa phytoliths from an archaeological site in South Cameroon, dating from the first millennium BC, document the first recorded presence of domesticated Musa bananas to Central Africa (Mbida et al. 2000).

\subsection{Stable Isotope Analysis}

Phytoliths record oxygen and carbon isotopic values of the environment from the time the plant was growing. It has been demonstrated that the stable isotope analysis of phytoliths can contribute considerable paleoenvironmental and paleoclimate evidence (Fredlund 1993; Kelly et al. 1991, 1998; Shahack-Gross et al. 1996; Smith and Anderson 2001; Smith and White 2004; Webb and Longstaffe 2000, 2002, 2003 and 2006). Phytoliths are believed to form in temperature-dependant equilibrium with plant water. Therefore, the oxygen isotopic composition of phytoliths has potential as a proxy for temperature and the $\delta^{18} \mathrm{O}$ values of precipitation during plant growth (Webb and Longstaffe 2000, 2002, 2003 and 2006.

It is also reasoned that plant carbon trapped within a phytolith was formed in part from atmospheric $\mathrm{CO}_{2}$ creating an atmospheric carbon isotopic signal from the time the plant was growing. Moreover, it has been confirmed by Kelly et al. (1991) that any carbon occluded within phytoliths is protected by the nonporous glass-like microstructure of the silica body and is therefore unlikely to decay. 


\subsubsection{Oxygen}

Deriving environmental and climate information from phytolith oxygen isotopes, is more complicated than from phytolith-occluded carbon. A number of different fractionation effects can occur through changes in temperature, evapotranspiration, and relative humidity. However, Webb and Longstaffe (2003) provide a recent modern introduction to the climatic factors affecting the isotopic composition of oxygen of $\mathrm{H}_{2} \mathrm{O}$ within growing plants, and how this relates to the oxygen isotopic ratios of phytolith silica. Because there is no known oxygen isotopic fractionation during the plant's uptake of soil water by roots, or during transport throughout a plant, they were able to determine that the air temperature is reflected by the $\delta^{18} \mathrm{O}$ of phytoliths formed within the non-transpiring (stems) tissue of grasses. However, in a sedimentary record the signal from non-transpiring tissue can be masked by phytoliths from transpiring (leaf) tissue, which in contrast is variably enriched in ${ }^{18} \mathrm{O}$ depending on relative humidity. Therefore, to reconstruct past temperatures accurately, $\delta^{18} \mathrm{O}$ of the soil water and relative humidity from ancient phytolith assemblages, phytoliths from non-transpiring tissue need to be separated from those from those from transpiring tissue. This has proved very difficult, but Webb and Longstaffe (2006) have devised a method which combines evidence from plant cellulose and phytoliths. By comparing the $\delta^{18} \mathrm{O}$ of the two plant products, they have been able calculate the proportion of leaf-versus stem-water $\delta^{18} \mathrm{O}$ values preserved in leaf phytolith silica under varying relative humidity conditions. Moreover, they use the $\delta^{18} \mathrm{O}$ values of leaf cellulose as a proxy of leaf water to calculate growing temperatures and the stem phytolith $\delta^{18} \mathrm{O}$ values to calculate soil water $\delta^{18} \mathrm{O}$ values.

\subsubsection{Carbon}

It has been shown that when phytoliths are forming within a plant cell, some of the carbon from the cell becomes enclosed by the gelling silica (Jones and Milne 1963, Fredlund 1993, Kelly et al. 1991, Wilding 1967). Kelly et al. (1991) has shown that phytoliths trap trace amounts of organic carbon (0.09-1.3 wt.\%), and Fredlund (1993) demonstrated that organic compounds can be attached to the 
silicates by hydrogen-bonding, or alternatively parts of the cytoplasm may become occluded within the phytolith as they silicify. In a review of this and subsequent work Piperno (2006) concluded that "some of the carbon from the cell becomes trapped by the penetrating, remaining the immune from post-depositional adulteration for as long as the phytoliths are stable in the sedimentary environment"

Wilding's (1967) isolation and radiocarbon analysis of phytolith carbon showed how more paleo-information could be obtained. Fredlund (1993) demonstrated that careful analysis of phytolith-occluded carbon had the potential for reconstructing a record of the range, variability and changes of $\mathrm{C} 3$ (around -27\%o $\delta^{13} \mathrm{C}$ ) and $\mathrm{C} 4$ grasses (around $-12 \%{ }^{13} \mathrm{C}$ ) of past grassland ecosystems. However, Smith and Anderson (2001) showed that the method was limited by the compression of the phytolith $\delta^{13} \mathrm{C}$ scale (range of $6.6 \%$ ) relative to the whole plant scale (range of 11.2\%o). Their study demonstrated that it was possible to characterize the phytolith organic compounds in $\mathrm{C} 3$ and $\mathrm{C} 4$ grass phytoliths using TMAH and GC-MS analysis. These analyses recorded the presence of lipids, which are generally depleted in $\delta^{13} \mathrm{C}$, and suggested therefore that lipid presence explains the depletion in $\delta^{13} \mathrm{C}$ in phytolith carbon relative to whole plant $\delta^{13} \mathrm{C}$. Moreover, they suggested that the isotopic differences in $\mathrm{C} 3$ and $\mathrm{C} 4$ grass phytoliths were most likely caused by differential fractionation associated with the formation of lipids in $\mathrm{C} 3$ and $\mathrm{C} 4$ plants. Smith and White (2004) have gone on to resolve some modern calibration issues raised in previous work, and by analysing a greater range of plants have been able to estimate accurately the values of the end-member of $\mathrm{C} 3$ and $\mathrm{C} 4$ phytolith carbon isotopic ratios. This allows for accurate measurement of the proportion of $\mathrm{C} 3$ and $\mathrm{C} 4$ grasses in ancient grasslands. 


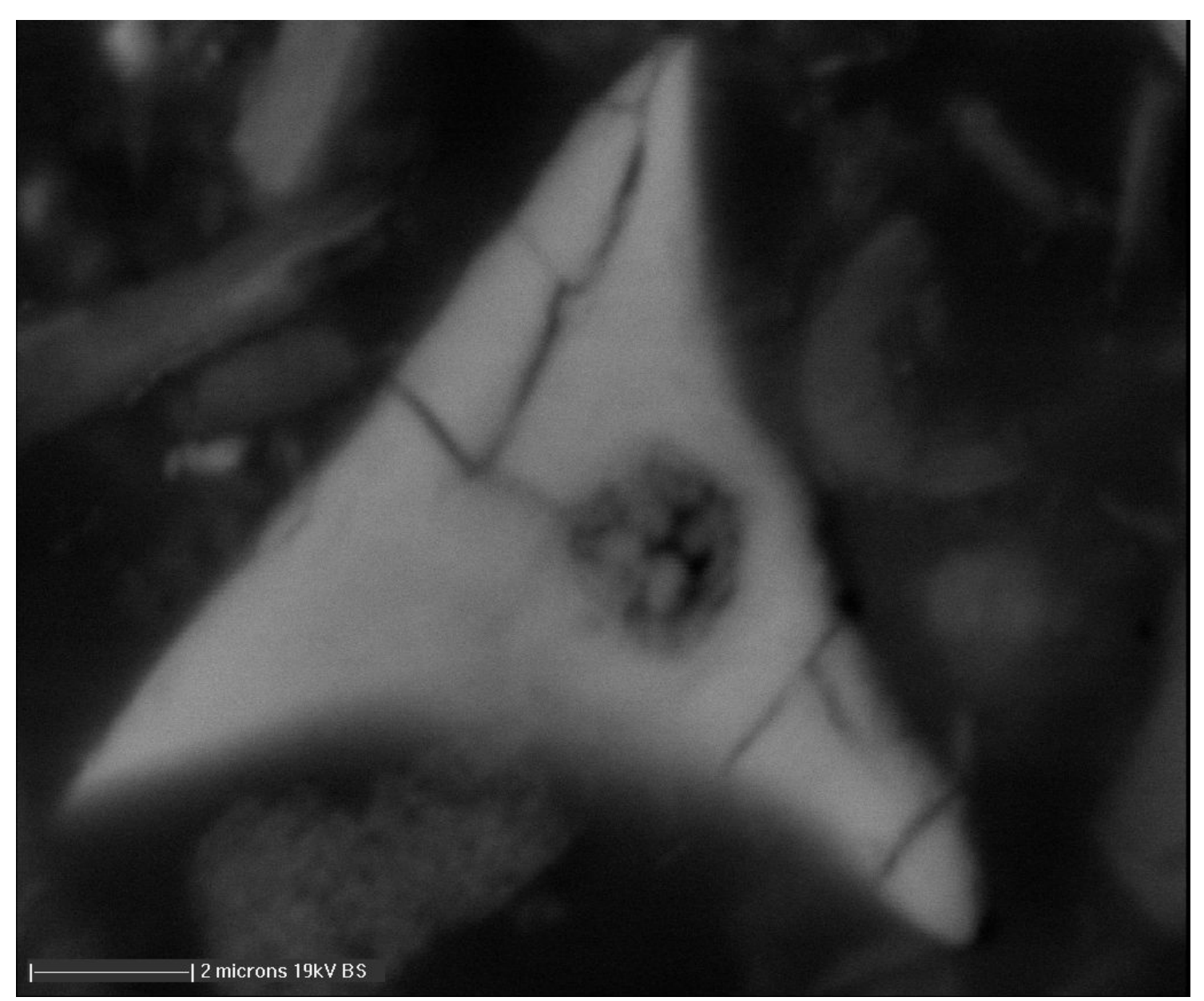

Fig. 1.8: A microprobe image showing occluded carbon within a phytolith from Festuca novae-zelandiae.

The research outlined above utilises the presence of carbon within phytoliths (Fig 1.8) as a proxy for ${ }^{13} \mathrm{CO}_{2}$ and this study builds further on that research. Because phytolith-occluded carbon within is derived from plant material formed by photosynthesis from atmospheric $\mathrm{CO}_{2}$, it should be possible to relate the ${ }^{13} \mathrm{C}$ of phytolith-occluded carbon with the concentration of ${ }^{13} \mathrm{C}$ in atmospheric $\mathrm{CO}_{2}$.

\subsubsection{DNA}

The presence of phytolith-occluded carbon creates an opportunity to identify the individual plant species in which the phytolith formed using DNA analysis. To develop this further, phytolith-occluded carbon was extracted from two modern New 
Zealand plants and submitted to Alan Cooper University of Adelaide for DNA analysis. At present no DNA has survived the extraction process, indicating a need for an improved extraction method.

\subsubsection{Stability of Phytolith-Occluded Carbon}

A basic assumption in the use of phytolith-occluded carbon is that the enclosed carbon remains immune from any post-depositional degradation. Wilding et al. (1967) demonstrated the resistance of carbon encapsulated within phytoliths to degradation by subjecting phytoliths containing carbon to a series strong oxidation agents. Extraneous and potentially contaminating carbon were removed from the surface of the phytoliths, while leaving the internal occluded carbon intact. To determine the degree of inaccessibility of occluded carbon to wet oxidation as a function of time, $\sim 0.5 \mathrm{gm}$ samples were digested in hot $\left(\mathrm{ca} .90^{\circ} \mathrm{C}\right) 5 \mathrm{~N} \mathrm{H}_{3} \mathrm{CrO}_{3}$ (chromic acid) for periods of 1, 2, 6, and 11 hours. They also used another method where a similar set of samples were digested in $20 \mathrm{ml}$. of $16.5 \% \mathrm{H}_{2} \mathrm{O}_{2}$ (hydrogen peroxide) on a steam bath for three hours. The percentage of total occluded carbon inaccessible to oxidation by hot $\mathrm{H}_{3} \mathrm{CrO}_{3}$ after various reaction periods is as follows: 1 hour, 55\%; 2 hours, 54\%; 6 hours, 51\%; and 11 hours, $18 \%$. Data from the $\mathrm{H}_{2} \mathrm{O}_{2}$ treatment supported that of $\mathrm{H}_{3} \mathrm{CrO}_{3}$, where about $50 \%$ of the total carbon was present following treatment (Wilding et al.1967).

Following the Wilding et al. (1967) experiments other workers have used a number of alternative phytolith digestion methods before measuring their $\delta^{13} \mathrm{C}$ values. Kelly et al. (1991) tested the hydrogen peroxide method of Wilding et al. (1967) by subjecting phytoliths to a series of oxidations. They found the mean carbon content prior to oxidation of samples to be $0.8 \pm 0.2 \mathrm{wt} \%$. Boiling the phytoliths in $18 \% \mathrm{H}_{2} \mathrm{O}_{2}$ for 6 hours reduced the organic carbon content to $0.2 \pm 0.2$ $\mathrm{wt} \%$, but that further boiling had no effect. Their experiments indicate that only surficial organic carbon is oxidised, leaving behind occluded carbon that is protected from oxidation by the nonporous glass-like microstructure. Smith and Anderson (2001) processed grass phytoliths using a wet oxidation method. This method is a slightly modified version of the previously published methods of Geis (1978) and 
Kelly et al. (1989). Plant material was heated in concentrated sulphuric acid at $70^{\circ} \mathrm{C}$ for 12 hours until all visible plant material was destroyed. After cooling, $30 \% \mathrm{H}_{2} \mathrm{O}_{2}$ was added slowly until the solution was clear. This method was used in this thesis to extract phytoliths from a range of modern plants. Subsequently, Parr and Sullivan (2005) used a new microwave digestion method (Parr et al. 2001) to extract phytoliths and measure carbon values from a series of sub-tropical soils from West New Britain. The microwave digestion method the samples are immersed in a mixture of $3 \mathrm{ml} \mathrm{HNO}_{3}$ (nitric acid) $2 \mathrm{ml} \mathrm{H}_{2} \mathrm{O}_{2}$ (hydrogen peroxide) and $0.5 \mathrm{ml} \mathrm{HCl}$ (hydrochloric acid), and digested for 30 minutes. I did not use this method because I was concerned about the possibility of microwave process inducing spot high temperatures that might damage the phytolith and compromise the occluded carbon.

A literature search show that all research projects where phytolith-occluded carbon has been measured, have used one of the above digestion methods, and accept, either explicitly or inferred, the Wilding et al. (1967) hypothesis that phytolith-occluded carbon remains immune from any post depositional degradation (Bartoli and Wilding 1980, Fredlund 1993, Mullholland and Prior 1993, Kelly et al. 1991, Kelly et al. 1998, McClaran and Umlauf 2000, Parr et al. 2001, Parr 2002, Smith and Anderson 2001, Krull et al. 2003, Smith and White 2004, Parr and Sullivan 2005).

However, it is possible that some of the carbon removed during phytolith digestion is from the original carbon occlusion, which could alter the isotopic value of the phytolith-occluded carbon. It is also possible that the lower carbon isotopic $\delta^{13} \mathrm{C}$ values found in the phytolith-occluded carbon compared to whole plant material (Smith and Anderson 2001, Smith and White 2004, this study), and of ancient phytolith-occluded carbon, is the result of a leakage of isotopically heavier compounds during digenesis. For both of these scenario's to be the case, the compounds present would have to be arranged isotopically, with the heavier compounds towards the outside of the phytolith, and more exposed to oxidation. However, it is more likely that the isotopically heavy compounds would fractionate earlier during formation, and therefore be more insulated from oxidation. Therefore, until our knowledge of how carbon is encapsulated and what compounds are present within those occlusions, this hypothesis must remain speculative. 


\subsection{Phytolith History in New Zealand}

Phytolith research in New Zealand was initiated by Raeside (1964, 1970), who described phytoliths he found in some South Island soils. A small number of phytolith paleoenvironmental reconstructions were conducted during the early 1980's. However, during the late 1980's and early 90's a number of Japanese phytolith workers researched New Zealand's phytoliths, which culminated in the publication of "Opal phytoliths of New Zealand" by Kondo et al. (1994). This publication revived interest in the method, and since then the number of publications on phytoliths has markedly increased. These cover paleoenvironmental reconstruction, phytolith morphology and archaeological studies (Table 1.1).

\subsection{Conclusion:}

This review demonstrates that phytoliths can be faithful recorders of $\delta^{13} \mathrm{C}$ of atmospheric $\mathrm{CO}_{2}$ on timescales ranging from centuries to millions of years. Phytoliths encapsulate plant carbon, creating in effect a tiny glass capsule with the memory of the plant and the atmosphere when they were formed. Following isotopic analysis, the biological fractionation effects that result from changes in temperature and precipitation are subtracted from the raw ${ }^{13} \mathrm{C}$ signal, revealing an atmospheric $\delta^{13} \mathrm{CO}_{2}$ signal from the time the plant was growing. Moreover, use of information from phytolith morphological analysis gives good indication of past vegetation and environments. This work greatly extends the potential of phytoliths as a proxy for climate and environment by providing a new method of recording changes in atmospheric $\delta^{13} \mathrm{C}$. 
Table 1.1: List of publications where phytoliths have been used in research in New

Zealand.

\begin{tabular}{|c|c|c|}
\hline Author & Title & Date \\
\hline Raeside, J.D. & $\begin{array}{l}\text { Loess deposits of the South Island, New Zealand and the soils } \\
\text { formed on them. }\end{array}$ & 1964 \\
\hline Raeside, J.D. & Some New Zealand plant opals & 1970 \\
\hline Sase, $\mathrm{T}$. & Plant opal analysis of Andisols in North Island, New Zealand & 1986 \\
\hline Weatherhead, A.V. & The occurrence of plant opals in New Zealand soils & 1988 \\
\hline $\begin{array}{l}\text { Sase, T., Hosono, M., Utsugawa, } \\
\text { T., Aoki, K. }\end{array}$ & $\begin{array}{l}\text { Opal phytolith analysis of present and buried volcanic ash soils } \\
\text { at Te Ngae road tephra section, Rotorua Basin, North Island, } \\
\text { New Zealand - soil/vegetation relationships in the last } 20,000 \\
\text { years }\end{array}$ & 1988 \\
\hline $\begin{array}{l}\text { Hosono, M., Oba, Y., Sase, T., } \\
\text { Utsugawa, T., Aoki, K. }\end{array}$ & $\begin{array}{l}\text { Holocene volcanic ash soils at Waimangu Road tephra section, } \\
\text { North Island, New Zealand - soil formation/vegetation } \\
\text { relationships }\end{array}$ & 1991 \\
\hline Kondo, R., Childs, C., Atkinson, I. & Opal phytoliths of New Zealand & 1994 \\
\hline Carter, J.A. & $\begin{array}{l}\text { Site specific (Taihape) paleoenvironmental reconstruction of the } \\
\text { last } 25,000 \text { years using phytolith distribution as an indicator of } \\
\text { changes in past vegetational patterns }\end{array}$ & 1994 \\
\hline $\begin{array}{l}\text { Shulmeister, J., Soons, J.M., } \\
\text { Berger, G.W., Harper, M., Holt, S., } \\
\text { Carter, J.A. }\end{array}$ & $\begin{array}{l}\text { Environmental and sea-level changes on Banks Peninsula } \\
\text { (Canterbury, New Zealand) through three glaciation- } \\
\text { interglaciation cycles }\end{array}$ & 1999 \\
\hline Carter, J.A., Lian, O.B. & $\begin{array}{l}\text { Paleoenvironmental reconstruction from the last interglacial } \\
\text { using phytolith analysis, southeastern North Island, New Zealand }\end{array}$ & 2000 \\
\hline Carter, J.A. & Phytoliths from loess in Southland, New Zealand & 2000 \\
\hline $\begin{array}{l}\text { Horrocks, M., Jones, M.D., Carter, } \\
\text { J.A., Sutton, D.G. }\end{array}$ & $\begin{array}{l}\text { Pollen and phytoliths in stone mounds at Pouerua, Northland, } \\
\text { New Zealand: implications for the study of Polynesian farming }\end{array}$ & 2000 \\
\hline Gordon, H.W. & $\begin{array}{l}\text { An investigation of an archaeological Maori kumara cultivation } \\
\text { site, Okuora farm, Canterbury, New Zealand }\end{array}$ & 2000 \\
\hline $\begin{array}{l}\text { Shulmeister, J., Shane, P., Lian, } \\
\text { O.B., Okuda, M., Carter, J.A., } \\
\text { Harper, M., Dickinson, W., } \\
\text { Augustinas, P., Heijnis, H. }\end{array}$ & $\begin{array}{l}\text { A long late-Quaternary record from Lake Poukawa, Hawke's } \\
\text { Bay, New Zealand }\end{array}$ & 2001 \\
\hline $\begin{array}{l}\text { Horrocks, M., Deng, Y., Ogdon, J., } \\
\text { Sutton, D.G. }\end{array}$ & $\begin{array}{l}\text { A reconstruction of the history of a Holocene sand dune on Great } \\
\text { Barrier Island, northern New Zealand, using pollen and phytolith } \\
\text { evidence }\end{array}$ & 2000 \\
\hline Carter, J.A. & $\begin{array}{l}\text { Phytolith analysis and paleoenvironmental reconstruction from } \\
\text { Lake Poukawa, Hawke's Bay, New Zealand }\end{array}$ & 2002 \\
\hline $\begin{array}{l}\text { Soons, J.M., Moar, N.T., } \\
\text { Shulmeister, J., Wilson, H.T., } \\
\text { Carter, J.A. }\end{array}$ & $\begin{array}{l}\text { Vegetation and climate change on Banks Peninsula, South } \\
\text { Island, New Zealand }\end{array}$ & 2002 \\
\hline $\begin{array}{l}\text { Prebble, M., Schallenburg, M., } \\
\text { Carter, J.A.., Shulmeister, J. }\end{array}$ & $\begin{array}{l}\text { An analysis of phytolith assemblages for quantitative } \\
\text { reconstruction of late Quaternary environments of the Lower } \\
\text { Taieri Plain, Otago, South Island, New Zealand: } 1 \text { Modern } \\
\text { assemblages and transfer functions }\end{array}$ & 2002 \\
\hline Prebble, M., Shulmeister, J. & $\begin{array}{l}\text { An analysis of phytolith assemblages for quantitative } \\
\text { reconstruction of late Quaternary environments of the Lower } \\
\text { Taieri Plain, Otago, South Island, New Zealand: } 11 \\
\text { Paleoenvironmental reconstruction }\end{array}$ & 2002 \\
\hline Horrocks, M., Irwin, G.J. & $\begin{array}{l}\text { Pollen, phytoliths and diatoms in prehistoric coprolites from } \\
\text { Kohika, Bay of Plenty, New Zealand }\end{array}$ & 2003 \\
\hline Carter, J.A. & $\begin{array}{l}\text { Phytolith analysis of kumara and gourd: A method of providing } \\
\text { direct evidence of pre-historic farming in ancient Polynesia }\end{array}$ & 2003 \\
\hline Carter, J.A. & $\begin{array}{l}\text { Vegetation changes following volcanic eruptive events from } \\
\text { phytolith analysis from Lake Poukawa core, Hawke's bay, New } \\
\text { Zealand }\end{array}$ & 2003 \\
\hline Marx, R., Lee, D. & $\begin{array}{l}\text { Phytolith morphology and biogenic silica concentrations and } \\
\text { abundance in leaves of Chionochloa (Danthonieae) and Festuca } \\
\text { (Poeae) in New Zealand }\end{array}$ & 2004 \\
\hline Thorn, V.C. & $\begin{array}{l}\text { Vegetation reconstruction from soil phytoliths, Tongariro } \\
\text { National park, New Zealand }\end{array}$ & 2006 \\
\hline
\end{tabular}




\section{Chapter Two:}

\section{Paleoenvironmental Reconstruction using Phytolith Morphologies from Otaraia, Wairarapa}

\subsection{Introduction}

The New Zealand archipelago lies in the southern mid latitudes of the Pacific Ocean stretching across $24^{\circ}$ of latitude. Mountain ranges reach elevations of nearly 4,000 m, and climate varies from sub-Antarctic to subtropical. New Zealand's remoteness, its relatively recent human disturbance, and its richness in terrestrial geological and environmental information, provide an ideal setting for the study of paleoecological change through the late Pleistocene-Holocene period, in this part of the Earth.

A number of palaeoenvironmental and palaeoclimatic reconstructions have been made of New Zealand covering the last glacial period. Most cover the period from the Last Glacial Maximum (LGM) through to the present, while a small number cover the whole of the last interglacial-glacial cycle, spanning approximately 125,000 years (e.g. Alloway et al., 2006; Carter 2002; McGlone and Topping, 1983; McGlone, 1985; Moar and Suggate, 1996; Wright et al., 1995; Heusser and van der Geer, 1994; Newnham, 1999; Shulmeister et al., 2004, Vandergoes et al., 2005; Williams et al., 2005).

Most of the terrestrial descriptions are based on pollen records from scattered locations and representing relatively short periods of time. In contrast, phytoliths can be found in sediments deposited over longer periods of time under a number of different environments, providing an alternative body of proxy environmental and climatic information from the Quaternary period. Although phytoliths are found in most sedimentary deposits, they are particularly well preserved in North Island, New Zealand loess. In contrast, in South Island loess phytoliths are only well preserved down to a certain level (Carter 2000). The preservation differences between phytoliths in sedimentary deposits in the North Island vs. the South Island possibly happen because of the greater volumes of tephra in North Island sediments. 
This chapter shows how phytoliths extracted from a loess deposit are used to describe vegetation change in the southern Wairarapa Valley, North Island through the last interglacial- glacial cycle. Samples provide local paleoenvironmental data from the analysis of phytolith assemblage morphologies, which can be compared to the global climate $\delta^{13} \mathrm{C}$ signal in phytolith-occluded carbon, from phytoliths extracted from the same sediment samples (Chapter 4). 


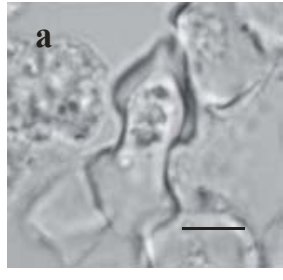

Bilobate short cell (grass origin)
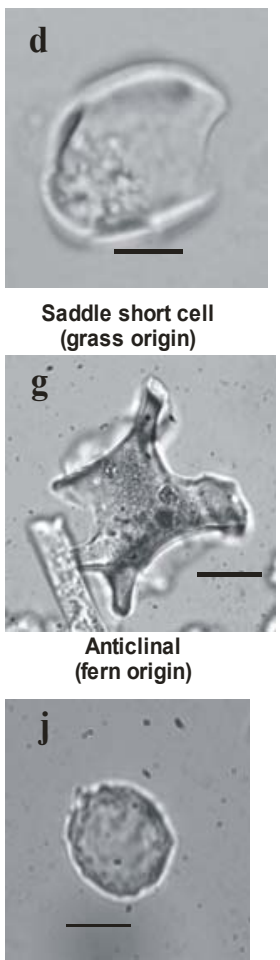

Globular granular (tree/shrub origin)

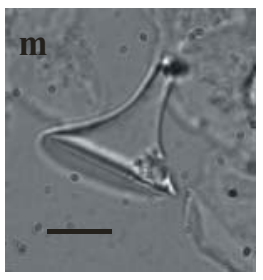

Conical hair base

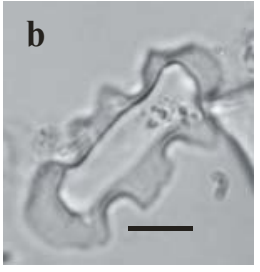

Trapeziform polylobate (grass origin)

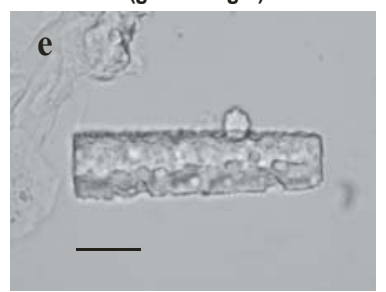

Elongate long cell (grass origin)

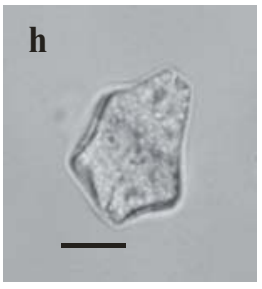

Polyhedral (tree/shrub origin)

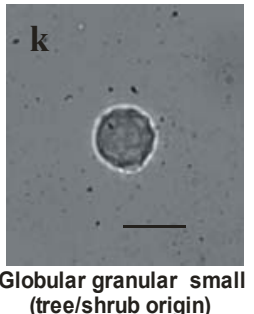
(tree/shrub origin)

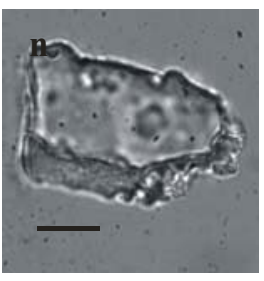

Tabular rectangle lacunose

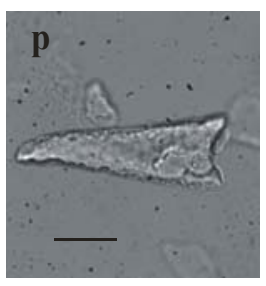

Aricular lanceolate

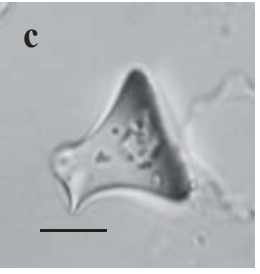

Conical short cell (grass origin)

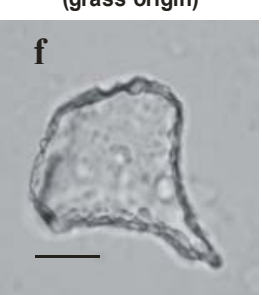

Cuniform bulliform (grass origin)

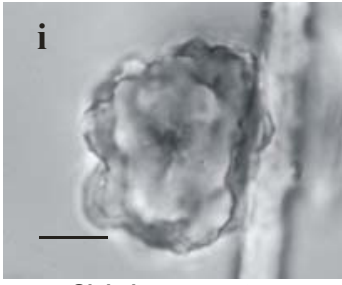

Globular verrucate (tree/shrub origin)

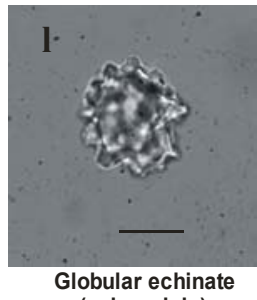
(palm origin)

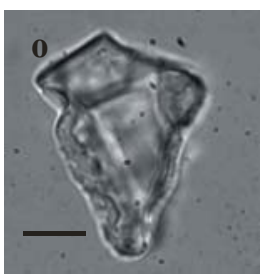

Tabular lanceolate lacunose

Fig. 2.1: Examples of repeatable phytoliths extracted from Otaraia loess core. (Scale bar $=10$ micron) 
Phytoliths separated from the 10m Otaria loess core (Fig. 1.1) were analysed using techniques that have been shown to provide a first-approximation of paleoenvironmental conditions. Dating control is from a tephra marker bed (Kawakawa/Oruanui Tephra $26.5 \mathrm{ka}$ ) and three optically stimulated luminescence (OSL) dates $45 \mathrm{ka}, 98 \mathrm{ka}$, and $116 \mathrm{ka}$ ).

\subsection{Previous Work}

Carter and Lian (2000) extracted phytoliths from a $6.4 \mathrm{~m}$ core from Bidwill Hill in the Wairarapa Valley and used phytolith analysis to reconstruct the last interglacial paleoenvironment of southeastern North Island, New Zealand. Correlation between tree-shrub phytolith fluctuations and the SPECMAP oxygen isotope curve, between MIS 1 and 5 suggested that changes in the ratio of arboreal to non-arboreal phytoliths directly result from changes in climate (Fig 1.7).

\subsection{Study Area}

The Otaraia core was one of a series of four cores collected in Wairarapa Valley in the early 1980's (Palmer, 1982). A number of distinct and indistinct breaks were noted in the $10 \mathrm{~m}$ core and may represent discontinuous loess deposition. The core sediments contain high numbers of well-preserved phytoliths in the first $7.4 \mathrm{~m}$. Below this level the phytoliths become unidentifiable and take on the form of randomly shaped biogenic silica platelets. These are similar to forms identified by Carter (2000). The cause of the change from identifiable to unidentifiable phytolith forms remains unknown.

The Otaraia core was drilled in a field approximately $20 \mathrm{~m}$ east of the Martinborough-Lake Ferry Road. The site is approximately $35 \mathrm{~m}$ above sea level on the lower North slope of the Aorangi range, on the seaward end of the Wairarapa Valley, approximately $15 \mathrm{~km}$ from Cook Strait (NZMS Grid reference S27 056886) (Fig. 1.2). The Wairarapa Valley is a structural depression plunging southward to Palliser Bay, bounded to the west by Rimutaka and Tararua ranges, to the southeast by the Aorangi range, with a range of low hills to the east. Late Tertiary marine strata within the valley are overlain by Pleistocene marine and terrestrial sediments 
recording eustatic rise and fall of sea-level in response to global climatic changes (Vella, 1963).

\subsubsection{Weather and Climate}

The weather of the Wairarapa Valley is controlled largely by the Rimutaka and Tararua ranges. When north-westerly winds blow across the region, the ranges can create adiabatic airflows which often cause high temperatures and dry conditions. During southerly and easterly conditions, rainfall generally increases and the air-masses are forced to ascend over the ranges. The prevailing winds in the southern Wairarapa are from the northwest, with slightly less from the southwest (Thompson 1982). Southerly winds are frequently of high velocity, and in contrast to the dry north-westerlies, are often heavily laden with moisture. Mean annual temperature is $12.8^{\circ} \mathrm{C}$ (1966-2005) with measured temperatures lying between $35.2^{\circ} \mathrm{C}$ and $-6.5^{\circ} \mathrm{C}$. Mean annual precipitation is $1106.6 \mathrm{~mm} / \mathrm{yr}(1932-2005)$. Annual mean sunshine is 2100 sunshine per year (NIWA, CliFlo). The climate of the Wairarapa is characterised by warm and dry summers, and cool and wet winters.

\subsubsection{Primeval, Recent Historic and Modern Vegetation}

During the Holocene, before human settlement of the Wairarapa, the vegetation was probably of continuous forest cover with extensive swamps around Lake Wairarapa. However, without pollen evidence, assumptions are made regarding the composition of these forests. These forests were probably similar in composition to those presently covering the slopes of the Rimutaka and Aorangi Ranges. The compositions of the forests on these ranges are of mixed podocarp/broadleaf with some Nothofagus at higher altitude. Following Maori migration into the area about 530 years BP (McFadgen 1980) and prior to the European migration into the area in the 1840 s, the vegetation of the Wairarapa was considerably varied. It consisted of approximately 81,000 ha of grassland, 32,000 ha of forest 10,000 ha of scrub and fern with 8,000 ha comprising swamp. The preEuropean vegetation is thought to have consisted of grasslands with scattered pockets of bush (Frontispiece, Fig 2.6 and Hill 1963). Since European settlement nearly all the original indigenous forest has been cleared for farming and present-day 
vegetation consists mainly of pasture grasses and some small pockets of native bush on the upper slopes of the Aorangi Range (Wardle 1967).

\subsection{Description and Age of the Loess Section at Otaraia}

The loess sediments of the Otaraia core are of mainly greywacke origin, derived from dust blown from aggrading alluvial fans and flood plains of the lower Wairarapa Valley, and the exposed continental shelf beyond. In general the core is fairly uniform but Palmer (1982) noted a number of features indicating breaks in deposition. He subdivided the core into three parts, correlating them from youngest to oldest with the Porewa, Rata and Ohakea loess, widespread in the Manawatu and Rangitiki regions. The Ohakea and Rata loess are relatively coarse and were blown directly from aggradation surfaces. The Porewa loess is fine ( $>40 \%$ clay) compared with the Rata and Ohakea loess ( $<30 \%$ clay). A brief description of each follows, based on Palmer (1982).

Ohakea loess ( 0 to $1.26 \mathrm{~m})$ is a mottled bright brown $(7.5 \mathrm{YR} 5 / 6)$ to a greyish yellowish brown (10YR 5/6) fine silt loam with some well-developed blocky structure. It is normally separated from the underlying Rata loess by the Bidwill Hill paleosol, though this is very weakly developed in the Otaraia core. The estimated age of the Ohakea loess age in the Manawatu and Rangitiki was between $25 \mathrm{ka}$ and $9.45 \mathrm{ka}$ (Milne and Smalley 1979). The age was partially based on the depth of the Kawakawa Tephra, which was originally dated as $\sim 20 \mathrm{ka}$, but has recently been given a radiocarbon age of 22, 590 years (Pillans et al. 1993).

Rata loess (1.26 to $3.54 \mathrm{~m})$ is a strongly mottled, dull yellow orange (10YR 6/4) massive firm sandy clay loam. Elsewhere the Rata loess is distinguished from the Ohakea loess by its stronger orange colour, silty clay loam texture and blocky structure. Weathering has modified the entire Rata loess in the Wairarapa, and that the colours and structure are usually associated with soil horizons. Palmer (1982) suggested that the Rata loess was deposited slowly, perhaps in a climate more humid than during the Ohakean time, between 50,000 and 30,000 years, an age range estimated using a combination of stratigraphy, lithology and correlation with high sea-level markers. An Optically Stimulated Luminescence (OSL) age of $44.7 \pm 2.7$ 
ka (Table 2.1) obtained for this study came from close to the bottom $(3.0 \mathrm{~m})$ of the Rata loess.

Porewa loess (3.54 to 7.31m) The Porewa loess is a very firm clay loam distinguished by its high clay content, with zones of abundant oxide concretions. The colour varies between light grey (10Y 7/1) and bright yellowish brown (10YR 6/6). Lacustrine sediments, which are the remains of the ancestral Lake Wairarapa, underlie it and its upper surface is recognised by a thick paleosol (Lake Ferry paleosol). Palmer (1982) estimated the age of the Wairarapa Porewa loess as between 80,000 and 60,000 yr BP using a combination of stratigraphy and correlation with a major regression in sea-level indicating a cold period, as suggested by Ghani (1974). This was then matched to the $\delta^{18} \mathrm{O}$ curve of Hays et al. (1976). Two OSL ages of $98.2 \pm 7.2 \mathrm{ka}$ at $4.9 \mathrm{~m}$, and $116.3 \pm 10.4 \mathrm{ka}$ at $7.0 \mathrm{~m}$ (Table 2.1) were estimated for this study from within the Porewa loess. Palmer (1982) suggested that this loess was probably derived from lacustrine sediment deposited in the ancestral lake that occupied the lower Wairarapa Valley at times during the last interglacial.

\subsection{Age model}

An age model is developed using the loess core log descriptions and derived ages of Palmer (1982), the Kawakawa Tephra, and Optically Stimulated Luminescence (OSL) ages of this study (Fig. 2.3, Table 2.1, Appendix 1). The conflict between the older and newer lines of evidence is addressed in the discussion section (2.8.1).

Table 2.1: Measured a-values and equivalent dose-rates and luminescence ages

\begin{tabular}{|c|c|c|c|c|c|}
\hline Sample no. & a-value & $\mathrm{D}_{\mathrm{e}}(\mathrm{Gy})$ & $\mathrm{dD} / \mathrm{dt}(\mathrm{Gy} / \mathrm{ka}$ & OSL-age (ka) & Field code \\
\hline WLL458 & $0.043 \pm 0.002$ & $122.5 \pm 4.3$ & $2.74 \pm 0.14$ & $44.7 \pm 2.7$ & JAC030 \\
\hline WLL459 & $0.044 \pm 0.007$ & $322.5 \pm 11.8$ & $3.29 \pm 0.21$ & $\mathbf{9 8 . 2} \pm 7.2$ & JAC049 \\
\hline *WLL460 & $0.063 \pm 0.016$ & $438.2 \pm 15.8$ & $3.77 \pm 0.33$ & $\mathbf{1 1 6 . 3} \pm \mathbf{1 0 . 4}$ & JAC070 \\
& & & $(3.89 \pm 0.33)$ & $\mathbf{( 1 1 2 . 6} \pm \mathbf{1 0 . 4 )}$ & \\
\hline
\end{tabular}

\footnotetext{
* This sample showed a radioactive disequilibrium and the given age was corrected accordingly. As the level of disequilibrium over time is unknown, this age is only a better estimate and cannot be seen as the "true" age. In brackets the uncorrected dose-rates and ages are given, calculated under the invalid assumption that the samples were in radioactive equilibrium (226Ra contents used for calculation).
} 


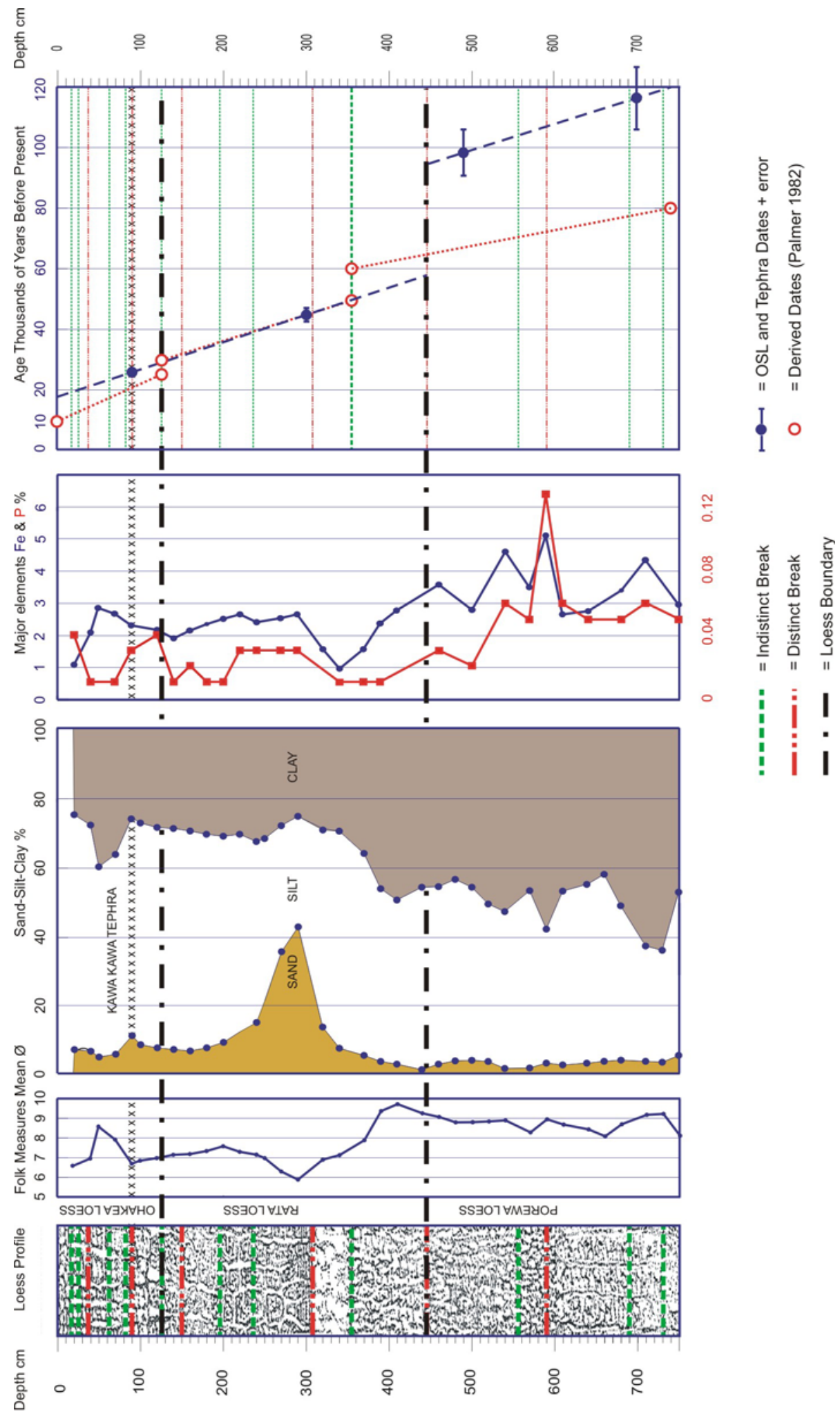

Fig. 2.2: Diagram of the Otaraia loess profile, mean grain size, sand, silt and clay percentages, major elements, iron and phosphorus and an age model showing the derived ages of Palmer (1982), the Kawakawa Tephra and OSL ages of this study. 


\subsection{Methods}

Phytoliths were extracted from samples collected at $10 \mathrm{~cm}$ intervals using a method described by Piperno (1988) and Hart (1988) (Fig. 2.1), and are classified using the International Code for Phytolith Nomenclature of Madella, Alexandre and Ball (2005). Preservation of phytoliths was very good and varied very little throughout the core. Judgement was made as to the origin of phytolith form types by comparing these with phytoliths from a personal reference collection, and with those described by Kondo et al. (1994). In order to determine the vegetation patterns at each level, the phytolith assemblages were compared against a modern analogue reference collection. Counts of 300 specimens per sample were converted into percentages of each form, and these were plotted as a stratigraphic frequency diagram (Fig. 2.3 and Appendix 2).

\subsection{Results}

Percentages of the 16 most common repeatable phytolith morphological forms are shown in Fig. 2.1, these define an eightfold stratigraphic zonation based on major changes in the ratios of arboreal and nonarboreal phytoliths (Fig. 2.3). The zone boundaries are based on the change from arboreal to grass dominated assemblages and vice versa. In order to elucidate the changes occurring down core, phytoliths from the major groupings "grasses" "fern" and "trees" are combined for each depth assemblage, and shown on the right of the stratigraphic frequency diagram. Included on the left of the diagram are the sedimentation rates, chronology and a loess stratigraphy column of Palmer (1982). In this study the term "graminoid" includes all grasses, rushes and reeds (Gramineae, Juncaceae, Cyperaceae, Typhaceae and Restionaceae) and is interchangeable with the term "grasses". The term "arboreal" is interchangeable with the terms "tree and shrub" and "trees". The term nonarboreal is interchangeable with the terms "graminoid" and "grasses". 


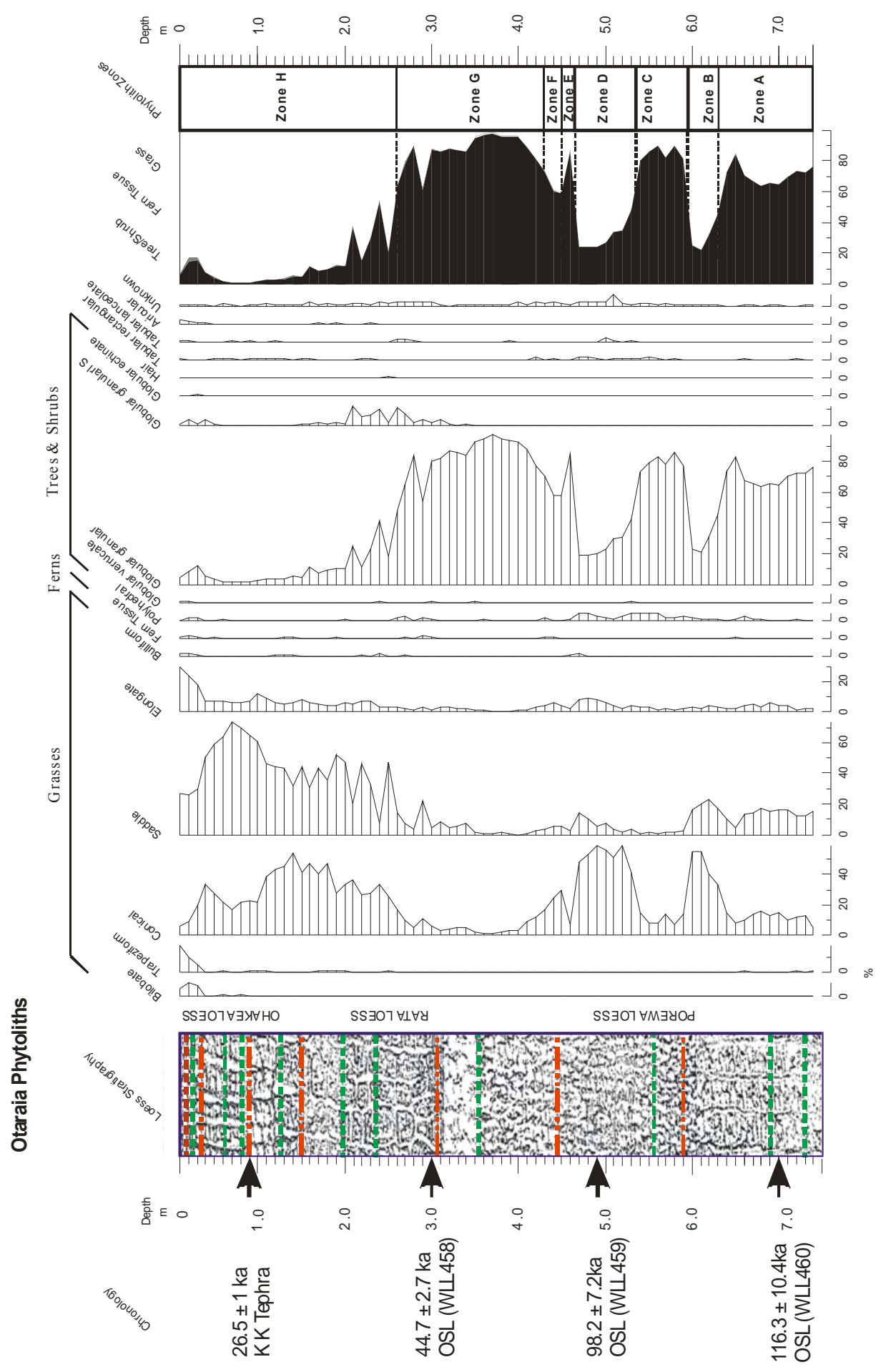

Fig. 2.3: Phytolith stratigraphic frequency diagram. Chronology, sedimentation rates and loess stratigraphy to far left. Grass forms to left, fern forms to centre and treeshrub forms and unknown to the right of centre panel. In addition, phytolith percentages are summarised into grasses, ferns and tree-shrubs. Zone stratigraphy is shown on the far right. 


\subsubsection{Zone A (7.4-6.3 m)}

Tree and shrub phytolith forms mainly, globular granular (Fig. 2.1 [j]) with a very small number of polyhedral forms (Fig. 2.1h), dominate this zone. The remainder is made up of graminoid forms; bilobate, trapeziform polylobate, conical, saddle, elongate and bulliform (Fig. 2.1 [a-f]). Arboreal phytoliths reduce slightly from $77 \%$ at $7.4 \mathrm{~m}$ to $64 \%$ at $6.8 \mathrm{~m}$ before rising to a maximum of $84 \%$ at $6.5 \mathrm{~m}$. From an arboreal maximum at $6.5 \mathrm{~m}$, tree and shrub phytolith percentages decline quickly being replaced in the main by graminoid conical and smaller numbers of saddle forms.

\subsubsection{Zone B $(6.3-5.95 \mathrm{~m})$}

Graminoid phytoliths, conical and saddle (Fig. 2.1 [c\&d]) dominate this zone with a peak of over $78 \%$ at $6.1 \mathrm{~m}$. Tree and shrub phytolith forms, mainly globular granular with very small numbers of globular verrucate and polyhedral, make up the remainder (Fig. 2.1 [h-j]. From $6.0 \mathrm{~m}$ to the zone C boundary, tree and shrub forms rapidly increase in number.

\subsubsection{Zone C (5.95-5.2 m)}

This zone is dominated tree and shrub (globular granular) and lesser amounts of polyhedral phytoliths, with two peaks of $90 \%$ at 5.8 and $5.6 \mathrm{~m}$. Between the two peaks there is a 5\% reduction in arboreal phytoliths and a corresponding increase in graminoid phytoliths. Above $5.6 \mathrm{~m}$ tree and shrub phytoliths are reduced in number and are replaced with graminoid conical, saddle and elongate forms (Fig. 2.3).

\subsubsection{Zone D (5.2-4.55 m)}

Graminoid phytolith forms, (mainly conical with lesser numbers of saddle and elongate forms) dominate this zone, and peak at 76\% between 4.9 and $4.7 \mathrm{~m}$. The majority consist of conical and lesser amounts of saddle, elongate and bulliform (Fig. 2.1 [d, e, \& f]) forms. Above $4.7 \mathrm{~m}$ tree and shrub phytolith forms (globular granular and polyhedral) replace the graminoid forms. 


\subsubsection{Zone E (4.55-4.4 m)}

This narrow zone is defined by a single sample at $4.5 \mathrm{~m}$ and is dominated by arboreal phytoliths, with globular granular forms.

\subsubsection{Zone F (4.4-4.2 m)}

Between $4.4 \mathrm{~m}$ and $4.3 \mathrm{~m}$ arboreal phytoliths are replaced by $42 \%$ of graminoid phytoliths, $30 \%$ conical, $6 \%$ saddle and $6 \%$ elongate phytoliths. Small numbers of fern anticlinal phytoliths are noted in this zone with $1 \%$ between 4.3 and $4.2 \mathrm{~m}$. From $4.2 \mathrm{~m}$ arboreal phytoliths gradually replace the graminoid phytoliths, reaching $73 \%$ at the top of the zone.

\subsubsection{Zone $G(4.2-2.5 \mathrm{~m})$}

From the beginning of this zone arboreal phytoliths (globular granular, with lesser amounts of globular verrucate, polyhedral and small globular granular forms) dominate, reaching a maximum of $98 \%$ at $3.6 \mathrm{~m}$. Above this depth arboreal phytolith numbers reduce slightly, before graminoid phytoliths increase sharply to $37 \%$ at $2.8 \mathrm{~m}$. Arboreal forms recover and increase to $90 \%$ at $2.7 \mathrm{~m}$. Above $2.7 \mathrm{~m}$ graminoid forms again increase to the zone boundary at $2.5 \mathrm{~m}$.

\subsubsection{Zone $H$ (2.5 $m$ to the surface)}

Graminoid forms (chionochloid, chloridoid and elongate and to a lesser extent bulliform) dominate Zone F. There is an increase in arboreal phytoliths to $54 \%$ at $2.3 \mathrm{~m}$ and $38 \%$ at $2.0 \mathrm{~m}$ and. Grass phytoliths rise to a maximum of $99 \%$ at $0.9 \mathrm{~m}$. From $0.3 \mathrm{~m}$, trapeziform phytoliths (Fig. 2.1 [b]) increase to a maximum of $7 \%$ at the top of the core. Bilobate phytoliths (Fig. 2.1[a]) are recorded in this zone only. At 0.8 and $0.6 \mathrm{~m}$ they record $1 \%$ and from $0.3 \mathrm{~m}$ to the surface they increase to a maximum of $9 \%$ at $0.2 \mathrm{~m}$. Trapeziform phytoliths increase from $0.3 \mathrm{~m}$ to the top of the core reaching a maximum of $17 \%$ at the top. Elongate phytoliths reach a maximum of $30 \%$ at the top of the core. This zone also contains the only palm phytoliths, (globular echinate) in the core, with $1 \%$ at $0.30 \mathrm{~m}$. 


\subsection{Discussion}

The phytoliths extracted from the loess core from Otaraia, Wairarapa, New Zealand provide a local environmental and climate record for the last 120,000 years. As noted earlier, no phytoliths were preserved below $7.4 \mathrm{~m}$. Changes in the phytolith assemblages are assumed to reflect changes in the vegetation patterns that occurred locally. These show landscape vegetation shifting between forests and grassland, with intermediate stages. In interpreting the Otaraia phytolith morphology assemblage changes, a simple hypothesis is proposed, that a forested landscape results from a warmer and/or wetter climate and grassland results from a colder and/or drier climate. However, it should be noted that there are two problems in relating phytolith forms found in assemblages extracted from sediments to plants of origin. The first, multiplicity of phytolith forms, where a number of different forms occur in the same plant and two, reproducibility, where phytoliths with a similar morphology are found in a number of different species (Piperno 1988). However, most phytoliths can be easily categorised into three major morphological groups. Grasses tend to produce a greater number of easily identified forms than other taxa (Fig.2.1 [a, b, c, d, e, \& f]). These grass forms also appear to have greater resistance to decomposition than ferns (pteridophytaea) phytoliths and some tree and shrub phytoliths. Ferns produce a large number of phytoliths; however, because of their wafer-like structure they are less resistant to decomposition and are generally poorly represented in phytoliths extracted from ancient sediments (Fig. 2.1 [g]). Polyhedral phytoliths produced in many trees and shrubs have a similar wafer structure and are similarly less resistant to decomposition and as such are also poorly represented in ancient assemblages (Fig. 2.1 [h]). In contrast many trees and shrubs also produce spherical phytoliths, which are very resistant to decomposition, and are found in many assemblages extracted from ancient sediments (Fig. $2.1[\mathrm{i}, \mathrm{j}, \mathrm{k}, \& \mathrm{l}]$ ). At this stage of phytolith analysis it is difficult to distinguish between spherical phytoliths from trees and shrubs, let alone phytoliths from individual species within either of these plant forms. There is however, exception to this in New Zealand. Palms produce a distinctive spherical (globular echinate) phytolith (Fig. 2.1 [1]). Because New Zealand has only one indigenous palm (Rhopalystylis sapida, nikau), phytoliths of this type are considered reliable indicators of contemporaneous nikau palms, when found in ancient sediments. Furthermore, because this palm species only grows in a 
relatively frost-free environment, its phytoliths are useful indicators of a warm climate (Cave and Paddison 1999).

When attempting to use tree/shrub phytoliths as a proxy for a climate, there is little difference between phytoliths derived from a lowland temperate podocarp forest (indicative of a warm and moist Interglacial climate) and a stunted Nothofagus forest (indicative of a colder and/or drier tree-line forest). However, assemblages of more than $80 \%$ arboreal forms give a good indication of a fully closed canopy typical of a temperate forest.

In this study most of the grass phytoliths in all assemblages are made up of conical and saddle forms. Conical forms were previously described by Kondo (1994) as "chionochloid", which they established as a new class of phytolith. They originate in the epidermal (short cells) of some Arundinoideae, and have been observed in the leaves of New Zealand genera Chionochloa and Cortaderia. In this study these phytoliths have been extracted from the leaves of modern Chionochloa rubra and Festuca novae-zelandiae. Saddle phytoliths originate from the short cells of Eragrostoideae, Bambusoideae, and some Arundinoideae (Kondo et al. 1994). In New Zealand this class of phytolith has been observed and extracted from the leaves of modern Chionochloa rubra and Festuca novae-zelandiae for this study. Phytoliths of this type have also been extracted from a number of other New Zealand tussock grassland species in this study and that of Kondo et al (1994). Chionochloa rubra is one of four physiognomically dominant species of tall tussock grasslands (grasses up to two metres tall). Festuca novae-zelandiae is the physiognomic dominant of short (less than $80 \mathrm{~cm}$ tall) tussock grasslands Connor and Macrae (1969). Therefore, when these phytolith forms make up more than $80 \%$ of an assemblage, it is assumed in this study they were derived from tussock grassland.

As with all paleoenvironmental interpretations, it is difficult in some cases to find modern analogs. While no exact modern equivalents of the low altitude grasslands exist for the colder periods of the LGM, it is assumed that these grasslands were of a similar composition as those found presently in higher and colder environments. 


\subsubsection{Chronology}

An age model is developed using the presence of one datable tephra, the Kawakawa/Oruanui Tephra (26.5 ka) (Pillans et al. 1993) at $90 \mathrm{~cm}$ and three Optically Stimulated Luminescence (OSL) ages $(44.7 \pm 2.7 \mathrm{ka}$ at $3.0 \mathrm{~m}, 98.2 \pm 7.2 \mathrm{ka}$ at $4.9 \mathrm{~m}$, and $116.3 \pm 10.4 \mathrm{ka}$ at $7.0 \mathrm{~m})$ (Fig 2.3, Table 2.1, Appendix 1). Included in the figure are the earlier ages of Palmer (1982). Here, ages are given for Ohakea loess of $9.45 \mathrm{ka}$ to $25 \mathrm{ka}$, for the Rata loess of $30 \mathrm{ka}$ to $50 \mathrm{ka}$ and the Porewa loess of $60 \mathrm{ka}$ to $80 \mathrm{ka}$.

There are number of obvious disagreements with the initial ages of Palmer (1982) and the OSL ages of this study. Reasoning that the Ohakea loess of the Wairarapa was correctly correlated with the Ohakea loess of Rangitiki and Manawatu, Palmer (1982) used the age range given to it by Milne (1973), and Milne and Smalley (1979). However, he suggested that because precise correlation cannot be made, the position of the Kawa Kawa tephra (then given an age of $20 \mathrm{ka}$ ) at two thirds of the depth was critical in giving an age to this loess. He went on to suggest that because of harsher climatic conditions in southern Wairarapa, loess deposition may have begun earlier than in the Rangitiki Valley. Moreover, because the Ohakea aggradation surfaces continued to aggrade to rising sea-level at the end of MIS 2, loess conditions may have also lasted longer. The Kawa Kawa tephra is now dated as $26.5 \mathrm{ka}$ (Pillans et al. 1993), which suggests that the bottom of this loess is older than this age.

Palmer (1982) calculated the Rata loess age as between $50 \mathrm{ka}$ and $30 \mathrm{ka}$. The OSL age of $44.7 \mathrm{ka}$ of this study close to the bottom of the Rata loess is in agreement with the bottom age of Palmer (1982).

The older Porewa loess age was determined by Palmer (1982), using a combination of stratigraphy, and a major regression in sea level suggested by Ghani (1974) as indicating a cold period, which was then matched to the $\delta^{18} \mathrm{O}$ curve of Hays et al. (1976). However, two OSL ages of $98.2 \pm 7.2 \mathrm{ka}$ at $4.9 \mathrm{~m}$, and $116.3 \pm$ 
$10.4 \mathrm{ka}$ at $7.0 \mathrm{~m}$, from this study are stratigraphically above the base of the Porewa loess, and are taken to be more reliable.

\subsubsection{Sedimentology}

When comparing the stratigraphic position of phytolith zones of this study and the paleosol formation and loess deposition described by Palmer (1982), there is little agreement. For soils (paleosols) to develop many changes have to occur over long periods of time before a given vegetation and its accompanying mature soil come into existence (Eyre 1967). For example, the requirements for a forest soil to develop at Otaraia are a long period (centuries or longer) of stable climate that was warmer, wetter and less windy than the colder periods of the last glacial cycle. Conversely, soils had difficulty in developing when grasslands dominated the landscape, the climate was colder and/or drier and windier, and loess was being deposited. However, it should be noted that one of the conditions for loess formation is that there is enough vegetation (grasses) to trap the particle and grains falling on the surface (Teruggi 1975). This view is that because of continual deposition of loess, there is not enough time for a recognisable soil to develop.

In addition to the three distinct periods of loess deposition and paleosol formation described by Palmer (1982), a combination of phytolith evidence (this study), grainsize, major element analysis, and evidence of further breaks in sedimentation, suggests three phases of loess deposition and three phases of reduced or nil sedimentation, within the Porewa loess period described by Palmer (1982). There are two long periods and one short period where grass phytolith assemblages are $80 \%$ or more, (phytolith zones B, D and F). During these periods, silt percentages rise and clay percentages fall, indicating a possible increase in loess deposition. In contrast, there are three major periods where tree/shrub phytolith assemblages are above $80 \%$, (phytolith zones A, C and E). During these periods, clay percentages rise and silt percentages decline, probably due to pedogenic weathering. During the same periods and increase in oxide nodules were noted visually in the core samples as well as by an increase in iron $(\mathrm{Fe})$ and phosphorus $(\mathrm{P})$ (Fig. 2.3). 
The combined evidence from silt and clay changes, iron and phosphorus changes, breaks noted in the core, and phytolith assemblage changes suggest that four models for the deposition of sediments at Otaraia are possible:

1) That sedimentation progressed steadily between breaks and the breaks represent periods of little or no erosion, and that sedimentation generally followed the path of the age model (Fig. 2.2).

2) That sedimentation above the break at $4.45 \mathrm{~m}$ generally followed the path of the model, but below the break followed the changes at the different zones, as described above.

3) That the distinct break at $4.45 \mathrm{~m}$ represents a period of erosion and/or nondeposition, and that apart from this break, sedimentation followed the path of the age model.

4) That the distinct break at $4.45 \mathrm{~m}$ represents a period of erosion and the sediment deposition below the break followed the changes at the different zones, as set out above, and that above this break, apart from the sediment deposition rates closely followed the age model path.

Here it is argued that model 4 is the most probable sedimentation model because of the following evidence. The phytolith zone directly below the break consists of assemblages of high tree and shrub phytolith percentages, raised level of clay and low level of silt, and high levels of Fe and $\mathrm{P}$, all of which suggest a warm interglacial period. The break occurs during a period when the phytolith assemblage is dominated by grass phytoliths indicating a cold climate. This model therefore, suggests that an undefined amount of sediment is missing at the break, which represents all of MIS 4, implying that phytolith zones D and C represent MIS 5b, 5c, and zones B and A represent MIS 5d and 5e.

\section{9: Paleoenvironmental Interpretation}

This data is aligned and correlated with the SPAMAP ${ }^{18} \mathrm{O}$ curve and MIS of Martinson et al. (1987) and the Vostok temperature curve of Petit et al. (2000) (Fig. 2.4). Marine isotope stage (MIS) boundaries have been designated on the basis of environmental changes shown in the phytolith assemblages and within the age 
model. In general there is reasonable agreement, but there are a number of prominent departures from the trends shown by Martinson et al. (1987) and Petit et al. (2001) and these are discussed in the next paragraph. The data from this study is also aligned and correlated to a New Zealand regional pollen record for the period $130 \mathrm{ka} \mathrm{BP}$ to the present (Vandergoes et al. 2005) (Fig. 2.5). 


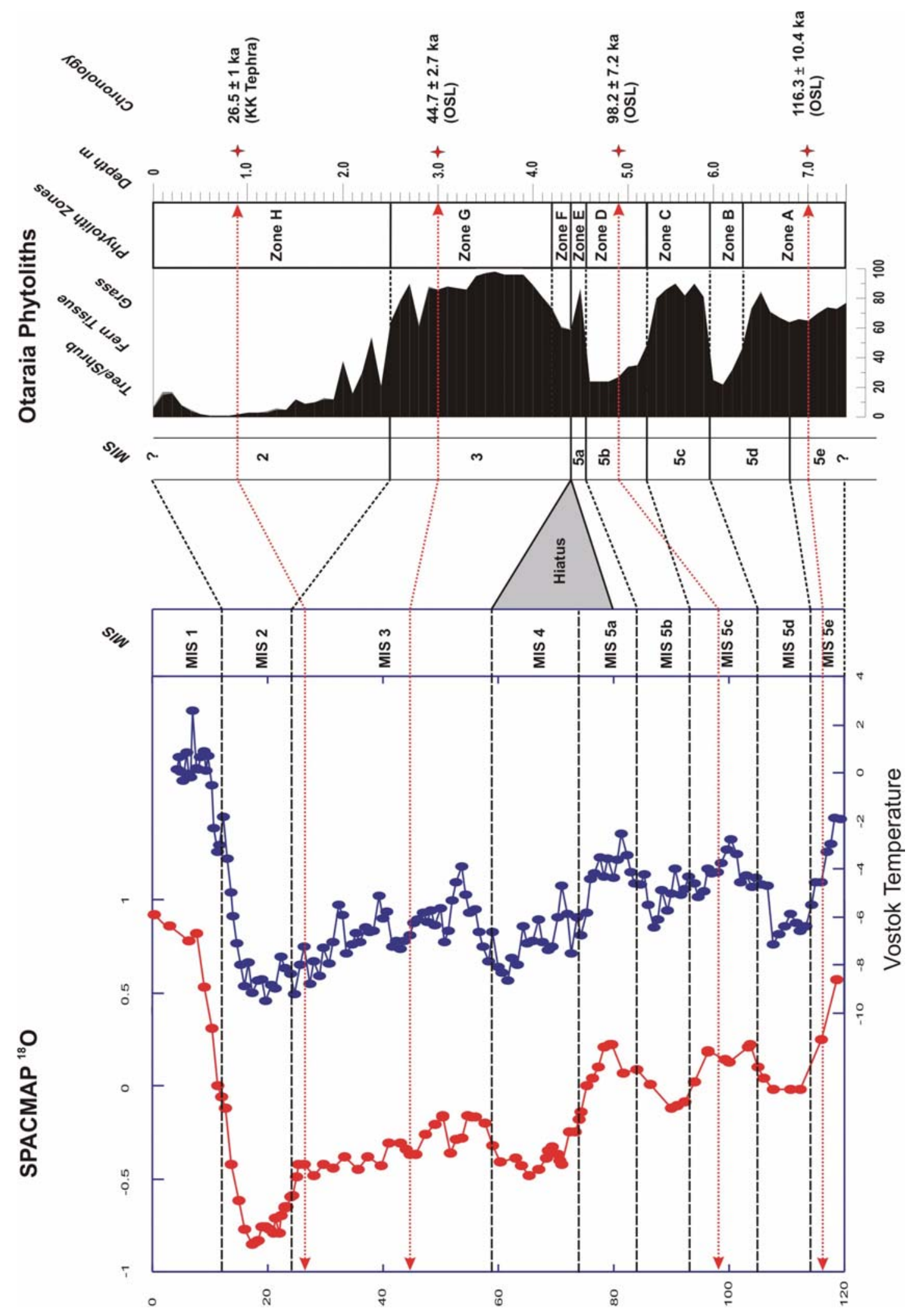

Fig. 2.4: Correlation diagram of ${ }^{18} \mathrm{O}$ SPAMAP data, and MIS of Martinson et al. (1987), Vostok temperature $\left({ }^{\circ} \mathrm{C}\right)$ data of Petit et al. (2001), and Otaraia phytolith data (this study). 


\section{Okarito Pollen}

\section{Otaraia Phytoliths}

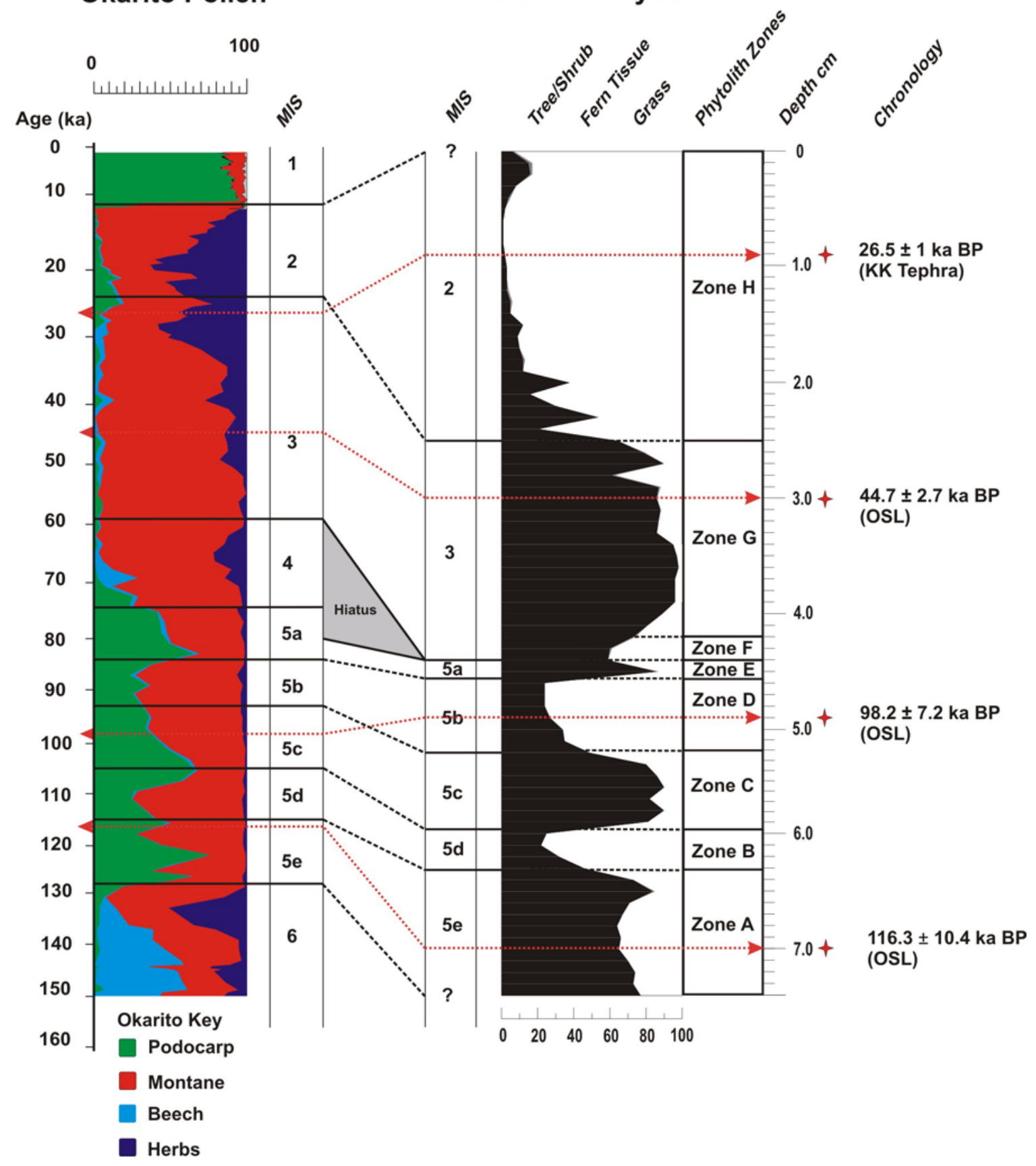

Fig. 2.5: Pollen data from Okarito (Vandergoes et al. 2005) correlated to phytolith data from Otaraia (this study)

The phytolith assemblage from this study is also compared to a number of pollen studies covering the same period from other regions throughout New Zealand. Okuda et al. (2002) and Shulmeister et al. (2001) used pollen analysis from the Lake Poukawa core to interpret changes in the regional paleoenvironment during the last glacial-interglacial cycle. A pollen study by McGlone and Topping (1983) described a number of major vegetation changes from Otamangakau in central North Island from about 80,000 years to the present. Although there is poor age control, some of 
the changes shown agree with those shown in this study. The Vandergoes et al. (2005) pollen study from South Westland gives one of the most complete descriptions of paleoenvironmental change in New Zealand for the last glacialinterglacial cycle. The lower half of their record has no direct age control, but the pattern of vegetation is consistent with the five subdivisions of MIS 5.

\section{Zone A (MIS 5e)}

Phytolith assemblages within zone A suggest a period when forests occupied the lower Wairarapa Valley (Fig 2.3, 2.4, and 2.5). As mentioned earlier, when analysing phytolith assemblages dominated by tree/shrub forms, it is difficult to distinguish between a lowland temperate podocarp forest (indicative of a warm and moist Interglacial climate) and a stunted Nothofagus forest (indicative of a colder and/or drier tree-line forest). However, pollen evidence from the same period from Hawkes Bay (100 km north of southern Wairarapa) (Okuda et al. 2002) and South Westland (450 km south of southern Wairarapa) indicate that during this period New Zealand had a warm moist temperate climate capable of supporting lowland podocarp/hardwood forests. Okuda et al. (2002) used pollen analysis to show that the vegetation consisted of lowland podocarp/hardwood forests in southern Hawkes Bay during MIS 5e. Their pollen assemblages had high levels of tall podocarps (Podocarpus/Prumnopitys and D. cupressinum), hardwoods (Plagianthus and Metrosiderous) and tree ferns (Cyathea and Dicksonia). They go on to suggest that the high levels of $D$. dacrydioides and a combination of Nikau palm evidence indicate that during the MIS 5e this region was significantly wetter than the Holocene. This evidence is also consistent with pollen data from South Westland showing an expansion of podocarp/hardwood forest during MIS 5e (Vandergoes et al. 2005) (Fig 2.5). Using pollen from cores taken from Okarito Pakihi, they suggest that these forests consisted of species such as Dacrydium cupressinum (rimu), Dacrycarpus dacrydiodes (kahikatea) and Weinmannia racemosa (kamahi), with grasses growing in forest clearings. Therefore, given the dominance of tree and shrub phytoliths in this zone, it is reasonable to assume that similar conditions and vegetation occurred in the southern Wairarapa during the same period. 
The Otaraia core data show an indistinct contact at $6.9 \mathrm{~m}$, which is underlain by layer where clay percentages reach a maximum of $43 \%$ and Iron $(\mathrm{Fe})$ and Phosphorus (P) are at high levels of 0.06 and $4.35 \%$ respectively (Fig. 2.3). High clay percentages suggest a soil that has been subjected to severe chemical weathering. Moreover, iron oxides concretions are formed in soil B-horizons which are subject to seasonal wetting and drying, and phosphorus values are highest in soil C-horizons, indicating the formation of soils during a period of little or no loess deposition under a warm and moist climate. Therefore, the above evidence combined with $84 \%$ arboreal phytoliths and $1 \%$ fern phytoliths, and an OSL date of 116,300 years before present (yr BP) at $7.0 \mathrm{~m}$ indicate that the Zone A equates to late Marine Isotope Stage (MIS) 5e.

\section{Zone B (MIS 5d)}

In Zone B grass phytoliths make up to $80 \%$ of the assemblage, suggesting a landscape dominated by grasslands with occasional shrubs and stunted trees (Fig. 2.4). During the same period, Okuda et al. (2002) interpreted a very low pollen count as indicating sparse vegetation in Hawkes Bay due to harsh climatic conditions. Vandergoes et al. (2005) showed that during this period in South Westland there was a decline in lowland temperate podocarp/broadleaf forest and a corresponding increase in montane subalpine shrubs.

The loess sediment record shows a distinct contact at $5.9 \mathrm{~m}$ immediately above a zone of low clay (42\%) and high silt (55\%) at $6.6 \mathrm{~m}$, indicating loess deposition and reduced soil formation. Moreover, Fe and $\mathrm{P}$ percentages reduce to $2.7 \%$ at $6.1 \mathrm{~m}$ and $0.05 \%$ at $6.4 \mathrm{~m}$ respectively, and grass phytoliths increase to $80 \%$ of the assemblage at $6.1 \mathrm{~m}$. Chronologically and environmentally the data from Zone B support a cold period, perhaps MIS 5d as shown in Martinson et al. (1987) and Petit et al. (2001) (Fig. 2.4). Dates from the age model of this study (Fig. 2.3) also compare with dates for MIS $5 \mathrm{~d}$ in Vandergoes et al. (2005). The combined evidence suggests Zone B sediments represent a period of relative rapid loess deposition during a cold, dry and windy climate, probably late MIS 5d. (Fig 2.3). 


\section{Zone C (MIS 5c)}

The high percentages of tree and shrub phytoliths in Zone $\mathrm{C}$ suggest a temperate lowland podocarp forest similar to that of Zone A dominating the southern Wairarapa landscape (Fig 2.4). However, the pollen data of Okuda et al. (2002) from Hawkes Bay were unable to distinguish between MIS 5c and MIS 5a and refer to the combined substages as the MIS $5 \mathrm{a} / 5 \mathrm{c}$ phase. Their pollen data show a mixed shrub forest, with significant amounts of Nothofagus menziesii and a background of forest podocarps and shrubs, suggesting a cool climate with temperatures $3.5-7^{\circ} \mathrm{C}$ lower than today. Vandergoes et al. (2005) interpret pollen data from South Westland to indicate that during the same period, podocarp/hardwood forests expanded corresponding to MIS 5c (Fig. 2.5). Grain size data indicate that zone $\mathrm{C}$ is directly underlain by a distinct break at $5.9 \mathrm{~m}$ which is overlain by two layers where clay percentages reach highs of $53 \%$ at $5.4 \mathrm{~m}$ and $58 \%$ at $5.9 \mathrm{~m}$. Moreover, Fe and $\mathrm{P}$ percentages increase to highs of $4.6 \%$ and $0.06 \%$ respectively at $5.4 \mathrm{~m}$, and a profile maximum of $5.1 \%$ and $0.13 \%$ respectively at $5.9 \mathrm{~m}$. There is also an indistinct break at $5.56 \mathrm{~m}$. The breaks which effectively form a boundary around the peaks of tree and shrub phytoliths might represent a reduction in loess deposition during the period when forests dominated the region, or they could represent erosion events. The combined evidence from tree and shrub phytolith numbers, grain size and $\mathrm{Fe}$ and $\mathrm{P}$ percentages, suggests zone $\mathrm{C}$ sediments were formed in a period of little or no loess deposition under a warm and moist climate during MIS 5c (Figs. 2.3, 2.4, and 2.5).

\section{Zone D (MIS 5b)}

In Zone D, a cold and dry climate is indicated by a major reduction of tree and shrub phytoliths, and a corresponding increase in grass phytoliths (up to $76 \%$, like zone B). A corresponding vegetation change is indicated by pollen evidence from South Westland for the same period, with a decline in lowland temperate podocarp/broadleaf forest trees and an increase in cooler montane subalpine shrubs (Vandergoes et al. 2005) (Fig. 2.5). There are no obvious breaks within zone D sediments, but as with zone B, low clay and high silt percentages of $43 \%$ and $53 \%$ respectively, at $4.8 \mathrm{~m}$ suggest an environment where loess deposition increased and soil formation has slowed or stopped. Fe and P percentages drop to 2.8 and $0.02 \%$ 
respectively, at $5.0 \mathrm{~m}$ and grass phytolith percentages increase to a maximum of $80 \%$ at $4.9 \mathrm{~m}$. Notwithstanding the lack of any discernable breaks within this zone, the combined evidence and an OSL age of $98.2 \mathrm{ka} \mathrm{BP}$ suggests zone D sediments represent another period of rapid loess deposition during a cold, dry and windy climate equating to MIS 5b (Fig. 2.4 and Fig 2.5).

\section{Zone E (MIS 5a)}

Arboreal phytoliths increase from a low of $\sim 50 \%$ to a maximum of $87 \%$ at $4.5 \mathrm{~m}$. This rapid increase suggests a change from a cool landscape of grasslands with shrubs and stunted trees to a warmer and moister forested landscape interspersed with grassy clearings (Fig 2.3). Shulmeister et al. (2001) described pollen from a similar mixed-podocarp forest on the south Wairarapa coast during MIS 5a. Pollen evidence from South Westland from the same period also indicates a similar rapid increase in lowland temperate podocarp/broadleaf forest (Vandergoes et al. 2005, Fig 2.5). Grain size data show a distinct break at $4.45 \mathrm{~m}$, and clay percentages rise slightly to $45 \%$ with a corresponding reduction in silt to $52 \%$ at 4.6 $\mathrm{m}$. Fe and $\mathrm{P}$ percentages increase to 3.6 and $0.03 \%$ respectively. The combined evidence suggests the sediments of phytolith zone E formed in a period of low loess deposition under a warm, moist climate (Figs. 2.3 and 2.4). The warm event at the start of this zone is believed to represent the beginning of MIS 5a (Petit et al. 2001) (Fig. 2.5). However, at this site there is only one data point, though MIS 5a lasted $\sim 10,000$ years (Martinson et al. (1987). Either sedimentation was extremely slow rates during this period, which is possible during a warm and wet phase, or an unconformity. The distinct break at $4.45 \mathrm{~m}$ (Fig 2.3) suggests the latter. In another pollen study McGlone and Topping (1983) documented a period in the Tongariro region where a subalpine forest-shrubland dominated by Libocedrus bidwillii replaced grassland at approximately $80 \mathrm{ka}$ BP, placing it stratigraphically in MIS 5a. The similarity in the phytolith evidence of this Zone with the pollen evidence of others for the same time period suggests that the chronostratigraphic position in the profile does represent MIS 5a at the Otaria site. 


\section{Zone F (MIS 4)}

In this narrow zone, graminoid phytoliths replace arboreal phytoliths suggesting a rapid change to a colder and or drier climate, possibly a cooler period within MIS 3. The break in sedimentation at $4.45 \mathrm{~m}$ (Fig 2.3) is probably a major unconformity. The hypothesis presented here is that this break represents missing sediment and phytolith data for most of MIS 4, and some of MIS 5a. However, because this change is based on two data points, any interpretation must remain speculative.

\section{Zone G (MIS 3)}

Tree and shrub phytoliths dominate this zone and increase to a maximum of $99 \%$ at $3.7 \mathrm{~m}$. The simplest interpretation for such an assemblage is that these phytoliths are derived from a warm temperate forest (Fig. 2.4). After $\sim 44.7 \mathrm{ka} \mathrm{BP}$ grass phytoliths increase and tree and shrub phytoliths decrease, suggesting a cooler and more open forest. Pollen data from Hawkes Bay for this period show conditions early in the MIS 3 were like the present interglacial, and that after $\sim 50 \mathrm{ka} \mathrm{BP}$ these changed to cool, wet and possibly windy conditions (Shulmeister et al. (2001). Okuda et al. (2002) also indicate that interglacial conditions existed in Hawkes Bay during the same period, with a podocarp-broadleaf forest, including moisture-loving Metrosideros spp. and tree ferns. McGlone (1985) presents pollen evidence supporting the presence of coastal lowland podocarp-broadleaf forests near Gisborne at this time. Grain size data show an indistinct break at $3.5 \mathrm{~m}$, and clay percentages reach a maximum of $49.19 \%$ and silt a minimum of $48.03 \%$ at $4.1 \mathrm{~m}$. Fe and $\mathrm{P}$ percentages reduce up the zone, reaching a minimum of $0.96 \%$ and $0.01 \%$, respectively. The combined evidence suggests the sediments of phytolith zone $G$ were deposited in a period of very slow loess deposition under a warm, moist climate (Fig. 2.4). Therefore, from the phytolith data and an OSL age of $44.7 \mathrm{ka}$ at $2.9 \mathrm{~m}$ it is considered that the period of Zone G corresponds to MIS 3. The phytolith assemblages continue to be dominated by tree and shrub phytoliths apart from a short period at $2.8 \mathrm{~m}$, where increasing grass phytoliths replace tree and shrub phytoliths. This change suggests a landscape of expanding grass and shrubland responding to a 
short period of a cooler and drier climate. At $2.5 \mathrm{~m}$ grass phytoliths replace tree and shrub phytoliths suggesting a major cooling.

\section{Zone H (MIS 2)}

The very high percentages of grass phytoliths and the presence of the Kawa Kawa Tephra support the view that this zone corresponds to the cold LGM period. The increase in grass phytoliths that began in Zone E continues, but, this trend is interrupted during two periods where the overall cooler and drier trend is punctuated by two periods of warmer and wetter weather. Grass phytoliths percentages reach a maximum of $99 \%$ at $0.9 \mathrm{~m}$, the same level as the Kawakawa Tephra. It is possible that the tephra cover, reported as being between 6 and $10 \mathrm{~cm}$ thick in the Wairarapa (Palmer 1982), exacerbated an already cooler and drier climate and created conditions more favourable for grasses to occupy the landscape. Moreover, Wright et al. (1995) reported sea-surface temperatures dropped $-2^{\circ} \mathrm{C}$ relative to the Holocene during the same period. These colder conditions are said to have resulted from an upwelling of cool subsurface waters caused by a stronger and persistent westerly airflow across New Zealand.

Above $0.9 \mathrm{~m}$ arboreal phytoliths increase, reaching a maximum of $16 \%$ between 0.2 and $0.1 \mathrm{~m}$, before reducing to $10 \%$ and being replaced by bilobate and trapeziform grass phytoliths at the surface. Bilobate and trapeziform phytoliths reach their highest numbers in this section of the zone, respectively $9 \%$ and $17 \%$. Bilobate phytoliths are attributed to warm climate grasses and trapeziform phytoliths have been reported in exotic pasture and native grasses in New Zealand (Kondo et al. 1994). The presence of these phytoliths and an overall increase in grass forms in the top $0.2 \mathrm{~m}$ of the core, suggests they originate from modern pasture grasses.

The small numbers of arboreal phytoliths in the top section of the core is perplexing. Under normal circumstances, with no breaks in the sedimentary record, one would expect arboreal phytolith numbers to recover following full glacial conditions, climaxing in a fully forested state, as they do in the South-Westland record of Vandergoes et al. (2005). Human and/or natural burning of the existing 
forest may have combined with very strong winds to erode large volumes of surface sediments from this landscape as the following points suggest.

1) Palmer (1982) described two distinct and one indistinct breaks in the top section of the core at $0.37,0.25$ and $0.17 \mathrm{~m}$, respectively. These breaks singularly or collectively may represent unconformities.

2) Paul Vella (pers com) observed that the surface of paddocks in the region was often up to $0.3 \mathrm{~m}$ below the bottom of older fence posts at the edge of the same paddocks. This suggests that up to $0.3 \mathrm{~m}$ had been removed by erosion following agricultural activity. Today, when paddocks are being prepared for seeding, high winds may erode large amounts of surface material.

3) Carle (1946) quoting Maori oral history states that, "In 1600 the Wairarapa was a vast forest of great totara trees, and as the kumara crops had failed after a drought, extra supplies of eels and trout $[s i c]$ were being taken out of the pools in the rivers and creeks. On the Opaki (just north of Masterton) plains eels were being dried over smoky fires when a heavy north-west wind sprang up and fanned the fires into a blaze which set alight the dry totara bark. The gale lasted several days and swept the fire to many parts of the valley. In the swamps and damp places, totara, matai and white pine survived along with other species, but large areas of bush were destroyed and later replaced by manuka, fern and native grass".

4) In New Zealand during El Niño events, stronger and more frequent winds from the west are experienced in summer, typically leading to drought in east coast areas and more rain in the west (NIWA, CliFlo 2006). Quinn and Neal (1992) describe a very strong El Niño event that occurred in 1578. They estimate that there were anomalous sea surface temperatures (SST) between $6^{\circ}$ and $12^{\circ} \mathrm{C}$ along the coasts of Peru and Ecuador, comparable to the 1982-83 El Niño event. Furthermore, during the $15^{\text {th }}$ century there were another 7 strong El Niño events, with SST anomalies of between $3^{\circ}$ and $5^{\circ} \mathrm{C}$ along the coasts of Peru and Ecuador, comparable to the 1972-73 El Niño event. 
5) Around Palliser Bay many Maori pa and gardening sites have been documented with aligned stones marking the boundaries of former gardens (e.g. Davidson 1984, Leach 1981, and McFadgen 1980). Leach (1981) said the original inhabitants of the area, the Rangitane, abandoned the area between 1550 and 1625 . He postulated that worsening climate caused the depopulation. New Zealand Historical Atlas (1997) describes wind and river erosion in the area, stripping garden soils and destroyed fishing grounds to force abandonment of this settlement over 400 years ago. After 1625 Ngati Kahungunu are said to have moved into the area.

It seems likely therefore, that a combination of a cooler and drier climate, possibly with a large El Niño event such as the ones documented above, created conditions where large amounts of surface sediment could be blown off the landscape. The same conditions would have made living difficult for Rangitane forcing them to abandon the Wairarapa. When Ngati Kahungunu re-colonised the area the open grasslands would have been more suitable for travel and hunting and I suggest that they maintained the landscape in the condition as sketched by Brees in Wakefield (1845) (Frontispiece and Fig. 2.6), by seasonal burning. The highest numbers of fern phytoliths $(2 \%)$ are found immediately above the highest number arboreal forms at $0.1 \mathrm{~m}$, indicative of landscape colonisation by bracken following the destruction of forest by fire. A similar series of events were noted in Hawkes Bay, when bracken fern-scrubland replaced lowland podocarp forest following permanent Maori settlement, Wilmshurst (1997).

\subsection{Conclusion}

The phytolith morphologies in the assemblages extracted and documented from the Otaraia loess core give a clear indication of the vegetation changes in the lower Wairarapa Valley in response to climate changes during the last glacial cycle. A series of vegetation changes are indicated by the waxing and waning of assemblages dominated by tree and shrub phytoliths to those dominated by grass phytoliths. These changes in the phytolith composition from the different zones are, in the main, consistent with the Marine Isotope Stages of Martinson et al. (1987) and temperature changes of Petit et al. (1999). Furthermore, there is close agreement between the paleoenvironmental reconstruction of this study and a number of other 
New Zealand regional reconstructions using pollen analysis (McGlone and Topping 1983, Shulmeister et al. 2001, Okuda et al. 2002 and Vandergoes et al. 2005). However, without adequate age control for the proposed unconformities, correlation with the marine isotope stages remains speculative. In order to improve the chronology, another suite of OSL samples has been taken, above and below a number of breaks in the section, and ages are expected in the near future. Notwithstanding these problems, this chapter presents one of the most complete vegetation-climate records yet determined for the last glacial-interglacial cycle in the North Island of New Zealand. It also provides evidence of the utility of phytolith analysis as a basis for investigating environmental and climate change.

Some will ask why use phytoliths when pollen can give such a better picture as to what plants were growing in a region at a given time? The answer is that pollen is less resistant to decomposition than phytoliths and requires anaerobic environments such as bogs and swamps. As a consequence these environments are local and patchy, and hence can provide only a limited and fragmentary record of past environments. In contrast, phytoliths are more resistant to decomposition, because of their silica composition, and are better preserved in most sedimentary deposits, and able to provide long unbroken records of environmental conditions through time. While phytoliths do not allow identification of individual species, they can give a very good indication as to the proportions of grasses, trees and shrubs, and ferns for a given place and time. 


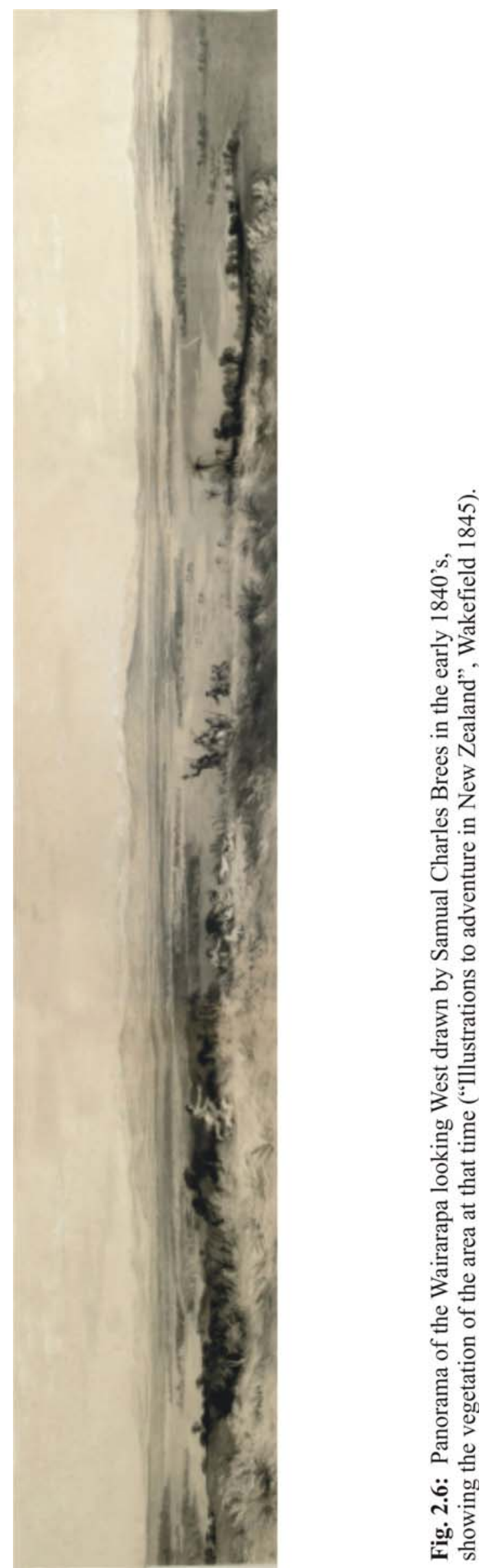




\section{Chapter Three:}

\section{Carbon Isotope Signatures in Modern Plant Phytoliths and Whole Leaf Material}

\subsection{Introduction}

Plant organic matter that has remained unaltered through time provides one of the best archives of environmental and climatic information for climate reconstruction (Schleser 1995). One way in which plant organic matter is preserved is through the precipitation of silica to form phytoliths. Phytoliths have been shown to contain between 0.09 to $1.3 \%$ organic carbon by weight (Wilding, 1967; Kelly, et al., 1991; Mulholland and Prior, 1993; Smith and Anderson, 2001). These studies have also shown that organic carbon trapped inside phytoliths is suitable for carbon isotope measurements since it remains protected from post-depositional contamination.

This chapter presents the results of isotope analysis of carbon occluded in phytoliths extracted from a number of modern New Zealand native plant samples. Although the main purpose of this research project is to determine a long-term atmospheric $\delta^{13} \mathrm{C}$ signal from phytolith-occluded carbon from a $7.4 \mathrm{~m}$ loess core, it was first necessary to obtain reference values for carbon isotope signatures from within phytoliths from modern plants. In order to understand the magnitude and characteristics of the natural variability of phytolith-occluded carbon a number of measurements were made. These included measurement of carbon isotopic fractionation between the atmosphere and whole plant material, measurement of carbon isotopic fractionation between whole plant matter and phytolith-occluded carbon, and a determination of carbon compounds present in phytolith-occluded carbon.

\subsection{Fractionation of Atmospheric Carbon Dioxide in Whole Plant Material}

The major processes by which atmospheric carbon is assimilated by plants are now considered to be reasonably well understood (Farquhar et al., 1982, Polley et 
al. 1993, Ehleringer and Cerling 1995, Evens et al. 1996). Atmospheric carbon dioxide is drawn into the leaves and incorporated into the leaves of plants during photosynthesis and is transferred throughout the plant by the vascular system (Fig. $3.1)$.

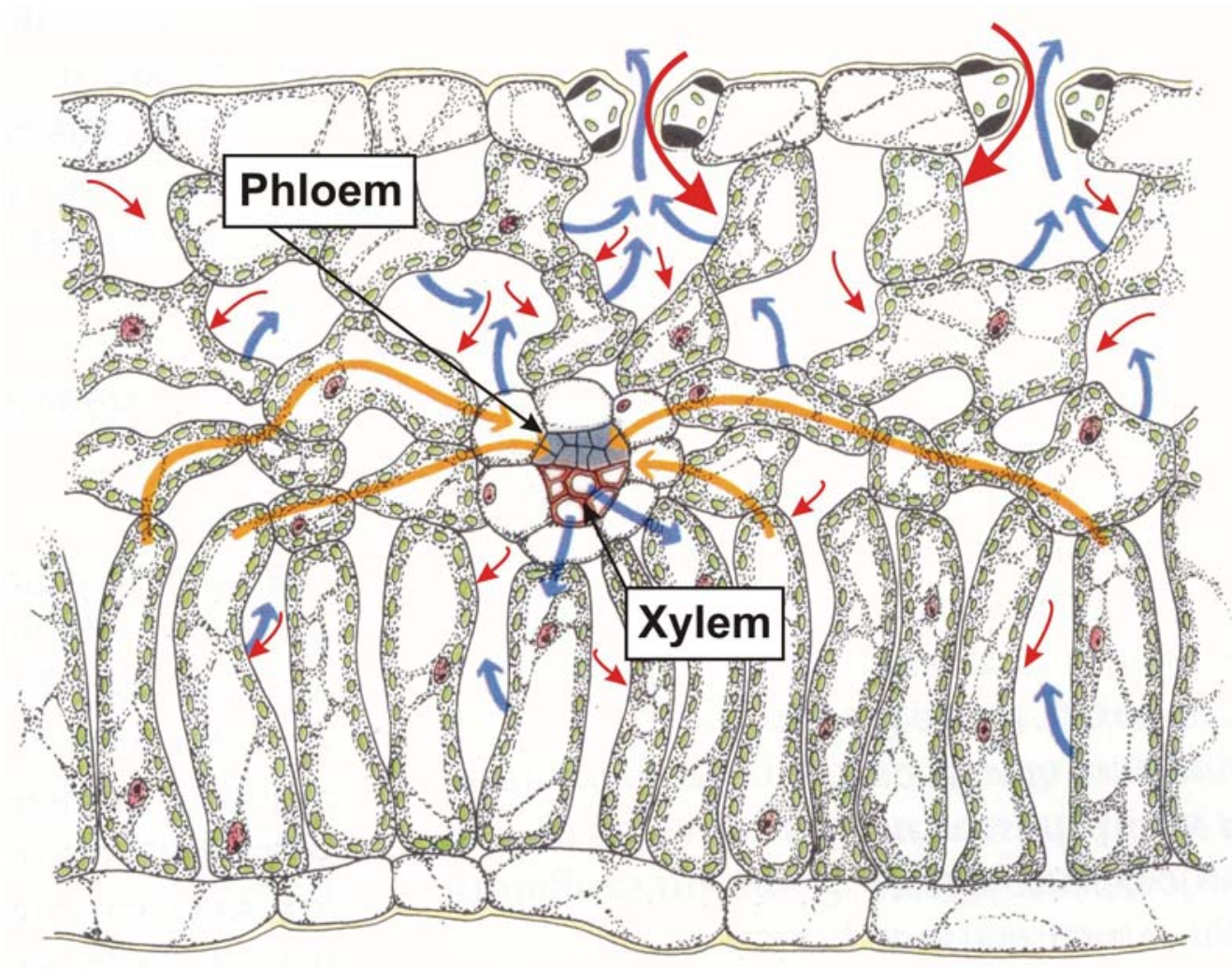

Fig. 3.1: Diagram showing the transport of carbon dioxide (red arrows) into the leaf through the stomata and throughout the leaf (modified from Raven (1999). The flow of water molecules is shown with blue arrows, from the xylem of a minor vein to the mesophyll cell walls, evaporating from the surface of cell walls, and out of the leaf through the stomata. At the same time, photosynthesised sugars and starches (orange arrows) are transported into the phloem and throughout the plant.

The $\delta^{13} \mathrm{C}$ value preserved in the plant material depends mostly on the atmospheric $\mathrm{CO}_{2}$ concentration and its $\delta^{13} \mathrm{C}$ value. However, other factors such as relative humidity, rainfall distribution and amount, cloudiness and temperature, may all have some additional influence on the $\delta^{13} \mathrm{C}$ value preserved in the plant. This range of possible climatic influences on plant $\delta^{13} \mathrm{C}$ has resulted in a number of 
models. The most widely used is that of Farquhar (1982). In his model the fractionation against ${ }^{13} \mathrm{C}$ relative to ${ }^{12} \mathrm{C}$ is related to the $\mathrm{p}_{\mathrm{i}} / \mathrm{p}_{\mathrm{a}}$ ratio of a leaf, where $\mathrm{p}_{\mathrm{i}}$ and $\mathrm{p}_{\mathrm{a}}$ are the internal and atmospheric $\mathrm{CO}_{2}$ concentrations respectively:

$$
\text { Eq.1 } \delta^{13} \mathrm{C}_{\mathrm{p}}=\delta^{13} \mathrm{C}_{\mathrm{a}}-a-(b-a) \times \mathrm{p}_{\mathrm{i}} / \mathrm{p}_{\mathrm{a}}
$$

Equation 1 relates the isotopic composition of plants $\left(\delta^{13} \mathrm{C}_{\mathrm{p}}\right)$, to the isotopic composition of the atmosphere $\left(\delta^{13} \mathrm{C}_{\mathrm{a}}\right)$, the fractionation through air during diffusion into the stomata $(a=4.4 \%$ ) and the fractionation caused by carboxylation ( $b$ generally given as $27 \%$ ). Therefore any change in atmospheric $\mathrm{CO}_{2}$ concentration will affect $\delta^{13} \mathrm{C}_{\mathrm{p}}$ through its effect on $\mathrm{p}_{\mathrm{i}} / \mathrm{p}_{\mathrm{a}}$.

Leaf internal $\mathrm{CO}_{2}$ is controlled by the demand for $\mathrm{CO}_{2}$ at the site of carboxylation in the chloroplasts and the supply of $\mathrm{CO}_{2}$ into the stomata (Croxdale 2001). If the rates of $\mathrm{CO}_{2}$ demand and supply are identical, internal concentration of $\mathrm{CO}_{2}$ in the leaf is fixed and $\delta^{13} \mathrm{C}_{\mathrm{p}}$ stays constant. However, if either the rate of demand or supply is faster or slower, the $\mathrm{CO}_{2}$ assimilation rate has to change, which will change $\mathrm{p}_{\mathrm{i}} / \mathrm{p}_{\mathrm{a}}$ ratios and therefore, result in a shift of $\delta^{13} \mathrm{C}_{\mathrm{p}}$. Consequently, changes in environmental conditions that affect assimilation rate or stomatal resistance can affect the isotope composition. However, because changes in one environmental factor normally cause changes in other environmental factors, it is often difficult to determine which factor is responsible for the changes and thus for possible shifts in $\delta^{13} \mathrm{C}_{\mathrm{p}}$ (Schleser 1995).

There are also a number of external factors that influence plant ${ }^{13} \mathrm{C}\left({ }^{13} \mathrm{C}_{\mathrm{p}}\right)$ composition and these are:

a) Light is essential for photosynthesis, and as such, changes in intensity affect plant physiological reactions. A number of studies have determined a relationship between ${ }^{13} \mathrm{C}_{\mathrm{p}}$ and irradiance levels (Ehleringer et al. 1986, Francey et al. 1985, Schleser 1990, Yakair and Israeli 1995, Le Roux-Swarthout et al. 2001). They show that change in light intensity, e.g., decreasing light level light with canopy depth, induce greater stomatal opening. This increases the $\mathrm{p}_{\mathrm{i}} / \mathrm{p}_{\mathrm{a}}$ 
ratio and in turn, increases the discrimination against ${ }^{13} \mathrm{C}$, resulting in lower leaf $\delta^{13} \mathrm{C}_{\mathrm{p}}$ than leaves from above the canopy. However, it should be noted that it is difficult in field measurements to separate light effects from other influences.

b) Temperature control of changes in ${ }^{13} \mathrm{C}_{\mathrm{p}}$ is poorly constrained, and in a natural situation it is difficult to separate its influence from other parameters (O'Leary 1988).

c) Water availability ${ }^{13} \mathrm{C}_{\mathrm{p}}$ becomes less negative as aridity increases (O'Leary 1981, 1988: Garten and Taylor 1982; Schleser 1995; Stewart et al. 1995; Heaton 1999). However, great variability exists between coefficients established by different researchers because of the extreme influence of other parameters, e.g., soil texture and type, vegetation type, and precipitation range and distribution. Water availability results in a complex balance among precipitation, annual distribution, evaporation, water runoff and drainage. Generally it is difficult to separate all the factors. However in the case of the loess samples of this thesis, it is assumed that there was little variation in water availability and therefore little influence on the ${ }^{13} \mathrm{C}_{\mathrm{p}}$ composition.

d) Atmospheric $\mathrm{CO}_{2}$ concentration (partial pressure of $\mathrm{CO}_{2}$ ) has been shown to have direct and quantitative effects on ${ }^{13} \mathrm{C}_{\mathrm{p}}$ (Farquhar et al. 1989). Several researchers have shown a well-defined negative relationship between $\mathrm{CO}_{2}$ and ${ }^{13} \mathrm{C}_{\mathrm{p}}$ (Krishnamurthy and Epstein 1990; Woodward 1993, Van de Water et al. 1994; Feng and Epstein 1995; Pasquier-Cardin et al. 1999). Feng and Epstein (1995) established a coefficient showing a decrease of $2.0 \pm 0.1 \%$ in ${ }^{13} \mathrm{C}_{\mathrm{p}}$ for an increase of $100 \mathrm{ppm}$ in atmospheric concentration.

e) Carbon Isotopic composition of atmospheric $\mathrm{CO}_{2}$ has been shown to be "the single most important parameter in explaining variation in the carbon isotopic composition of C3 plant tissue fixed during photosynthesis" (Arens et al. 2000). Arens et al. (2000) used a data set (519 measurements from 176 (C3) plant species to show that the $\delta^{13} \mathrm{C}$ value of atmospheric $\mathrm{CO}_{2}$ can be reconstructed from the isotopic composition of plant tissue. They performed a multiple linear regression upon $\delta^{13} \mathrm{C}_{\mathrm{p}}$ values using as variables $\delta^{13} \mathrm{C}_{\mathrm{a}}$ and the $\mathrm{C}_{\mathrm{p}} / \mathrm{C}_{\mathrm{a}}$ ratio of $\mathrm{CO}_{2}$. One model including both $\delta^{13} \mathrm{C}_{\mathrm{a}}$ value and $\mathrm{C}_{\mathrm{p}} / \mathrm{C}_{\mathrm{a}}$ was significant and accounted for $98.2 \%$ of total variation. Hence they concluded that the $\delta^{13} \mathrm{C}$ value of carbon 
dioxide fixed during photosynthesis was the most important parameter in explaining variation in the carbon isotopic composition of $\mathrm{C} 3$ plant tissue.

In summary, the main influence on ${ }^{13} \mathrm{C}$ of phytolith-occluded-carbon is the $\delta^{13} \mathrm{CO}_{2}$ value of the atmosphere at the time the occluded carbon was trapped by the plants, though other factors also have measurable influence.

\subsection{A History of Research into the use of C Isotopes in Phytoliths for Dating and Recognising Past Grass Types}

Phytoliths typically contain between 0.1 and $1 \%$ of carbon which is material from living cells trapped during phytolith formation. Phytoliths are formed within three areas of plant tissue: 1) cell wall deposits, often called membrane silicification, 2) infilling of the lumen, and 3) in the intercellular spaces of the cortex. Phytoliths are formed within cells by the incomplete silicification of the cell lumen or interior in grasses and trees and shrubs. The morphology of phytoliths produced this way does not conform to the original configuration of the cell (Piperno 1988). Therefore, in order to produce phytoliths of relatively consistent morphology, internal conditions must be relatively constant during phytolith formation. However, in spite of an incomplete knowledge of phytolith formation and carbon encapsulation within a plant cell, it is evident that when phytoliths form within the vacuoles of cells, they entrap cellular organelles and other carbon macromolecules. Moreover, complete cell organelles, such as mitochondria and plastids are often deposited in vacuoles, thereby creating a source of carbon for phytolith encapsulation (Raven 1999) (Figs. 3.2 and 3.3). 


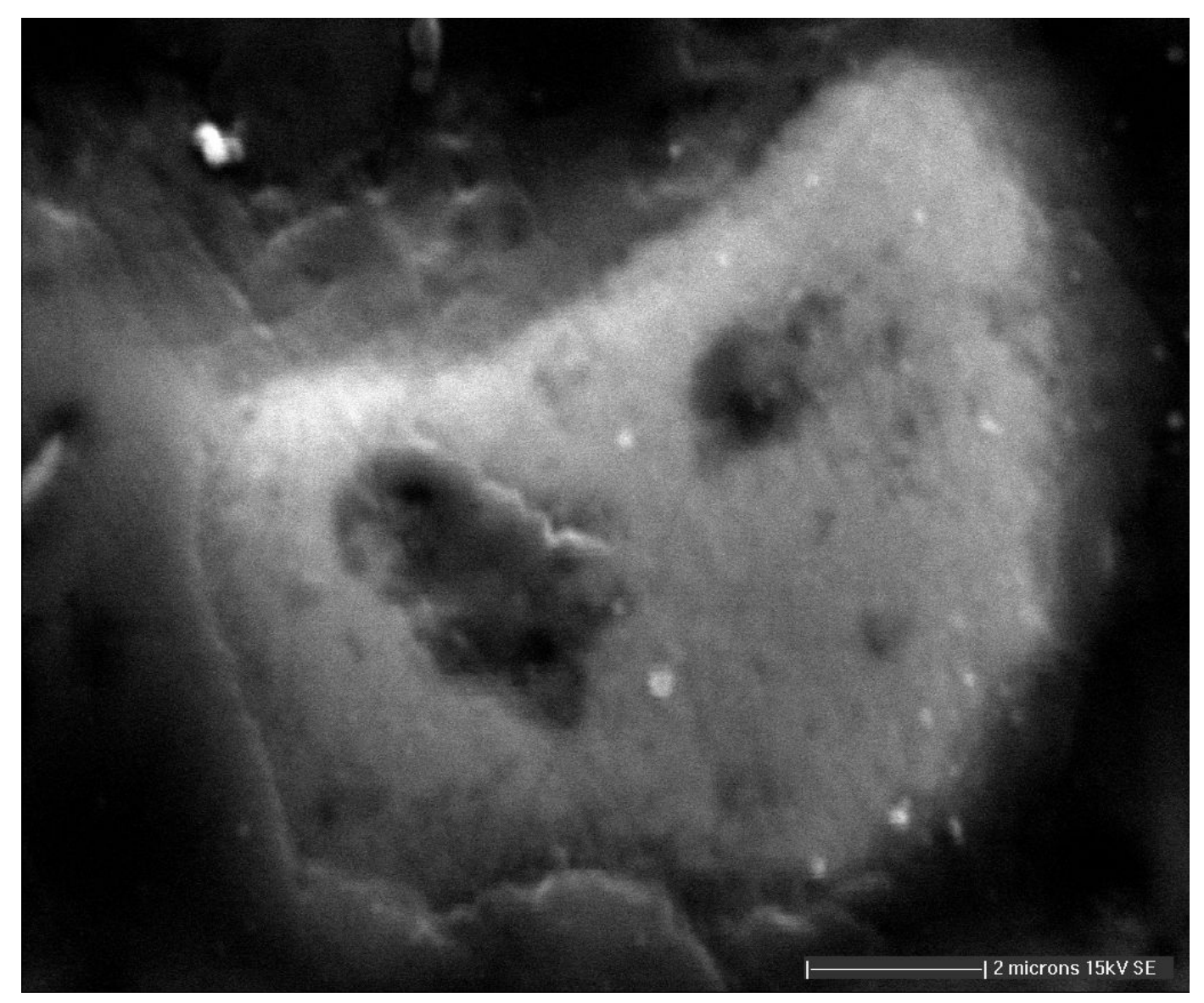

Fig. 3.2: Micro-probe image of a cross sectioned phytolith extracted from a native New Zealand grass species Festuca novae zelandiae). The dark areas within the phytolith are occluded carbon. 

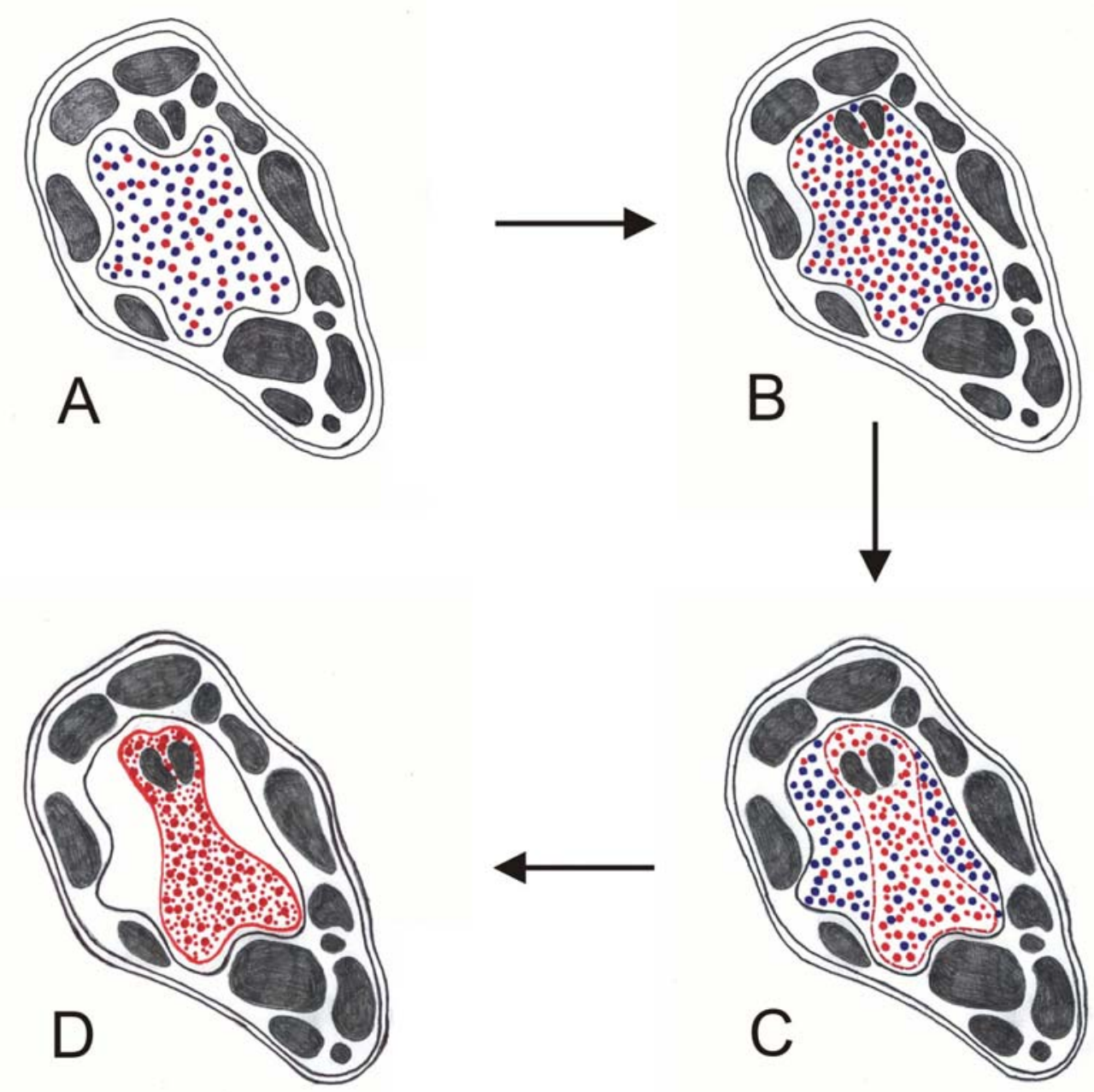

- Plant cell organelles, nucleus, chloroplasts, mitochondria, etc.

Plant cell sap

Silica, silicic acid, silica gel and solid silica

Fig. 3.3: A hypothetical model of how carbon becomes occluded during phytolith formation. A) Normal growing cell with the vacuole filed with cell sap (blue dots) containing silicic acid (red dots). During the interchange of liquids between the cell and rest of the plant, silicic acid is retained and concentration begins. B)

Concentration of silicic acid continues to increase, and two organelles moved into the vacuole. C) Concentration of silicic acid increases to a level where polymerisation takes place forming silica gel enclosing the two organelles. Constant internal cell sap pressure and/or other conditions cause the gel to take on a distinctive shape. D) 
During the senescence process liquid is removed from the cell, causing the gel to solidify, leaving a distinctive phytolith with carbon inclusions.

The first reports of phytolith-occluded carbon were those of Jones and Milne (1963), and Jones and Beavers (1963). Jones and Milne (1963) comprehensively examined the chemical and physical properties of the silica phytoliths found in oat plants Avena sterrilis. They found that the extracted phytoliths contained between 5 and 6\% carbon. Jones and Beavers (1963) followed this work with an examination of phytoliths extracted from a silt loam soil, determining some of their chemical and mineralological properties. They found that the amount of carbon present within the phytoliths approach $1 \%$ and concluded that the carbon was of cytoplasmic origin.

Wilding et al. (1967) followed up on a suggestion by Jones and Beavers (1963) that phytolith-occluded carbon would be satisfactory for radiocarbon dating by conducting a series of experiments on phytoliths extracted from a silt loam. They determined the chemical nature of phytolith-occluded carbon, the resistance of phytolith carbon to decomposition, and the impact of occluded carbon on certain physical and chemical properties of phytolith. Infrared absorption spectra confirmed the organic nature of the occluded carbon. They determined that over three times as much carbon is occluded in the light phytolith fraction $(1.5$ to $2.0 \mathrm{s.g}$. [specific gravity $\left.\mathrm{g} / \mathrm{cm}^{3}\right]$ ) as is present in the heavy fraction (2.0 to $2.3 \mathrm{s.g}$.). However, since the light fraction makes up only about a third of the total fraction $(<2.3$ s.g.), they stated there was little advantage in isolating only the lighter fraction. They also determined an inverse relationship between colour and specific gravity, basically, the darker the colour of the phytoliths the lower the specific gravity. To determine that all carbon within the phytoliths was stable and not contaminated, they subjected the phytoliths to rigorous oxidation conditions. This removed all extraneous carbon contaminants and the more easily accessible occluded carbon, leaving the more resistant fraction as a suitable source for radiocarbon dating.

Kelly et al. (1991) were the first to explore the possibility of using the stable isotopic composition of phytolith-occluded carbon to reconstruct paleoenvironments. They extracted and measured the carbon isotope composition of phytoliths from different depths from soil profiles from a number of sites across the northern Great Plains, United States. By radiocarbon dating the phytolith-occluded carbon they 
confirmed that the oldest phytoliths were found at depth, becoming younger toward the surface. They demonstrated that the phytoliths represented the plants growing on the surface, which were slowly buried under a continuous deposition of dust, resulting in a slow burial of the soil surface. Using the changes in carbon isotopic ratios of the phytolith-occluded carbon down profile they demonstrated that the percentages of $\mathrm{C} 3$ to $\mathrm{C} 4$ grasses had changed over the last 13,500 years. By exploiting the fact that $\mathrm{C} 3$ and $\mathrm{C} 4$ plants use different photosynthetic pathways, they were able to demonstrate that during the early Holocene the grasslands were dominated by $\mathrm{C} 3$ grasses, which were replaced over time by ones dominated by $\mathrm{C} 4$ grasses.

Fredlund (1993) demonstrated that careful analysis of phytolith-occluded carbon had the potential for reconstructing a record of the range, variability and changes of $\mathrm{C} 3$ (around $-27 \%$ o $\delta^{13} \mathrm{C}$ ) and $\mathrm{C} 4$ grasses (around $-12 \%$ o $\delta^{13} \mathrm{C}$ ) of past grassland ecosystems. McClaren and Umlauf (2000) combined the carbon isotope analysis of phytolith-occluded carbon and the soil organic matter from desert soils from south-western North America to show that $\mathrm{C} 4$ grasses have dominated the grassland for most of the last 8,000 years. However, Smith and Anderson (2001) have shown that the method is limited by the compression of the phytolith $\delta^{13} \mathrm{C}$ scale $(6.6 \%)$ relative to the whole plant scale $(11.2 \%)$. Their study demonstrated that it was possible to characterize some of the phytolith organic compounds in C3 and C4 grass phytoliths using TMAH and GC-MS analysis. These analyses record the presence of lipids, which are generally depleted in $\delta^{13} \mathrm{C}$, and suggest that the presence of lipids explains the depletion in $\delta^{13} \mathrm{C}$ in phytolith carbon relative to whole plant $\delta^{13} \mathrm{C}$. Moreover, they suggested that the isotopic differences in $\mathrm{C} 3$ and $\mathrm{C} 4$ grass phytoliths were most likely caused by differential fractionation associated with the formation of lipids in C3 and C4 plants. Smith and White (2004) have gone on to resolve some modern calibration issues raised in previous work and show that the carbon isotope ratios of fossil phytoliths present a unique tool for reconstructing the proportion of $\mathrm{C} 3$ and $\mathrm{C} 4$ grasses in ancient grassland. However, while their method only determined the presence of lignins and the absence of lipids, it does not allow for the detection of carbohydrates. Because carbohydrates such as cellulose and hemicellulose comprise $57-77 \%$ by weight of dry plant material, and they can either 
be enriched by $1-2 \%$ or depleted by $1-4 \%$ in ${ }^{13} \mathrm{C}$ (Benner et al., 1987; Deines, 1980), much remains unknown as to the compound composition of phytolith-occluded carbon.

In view of the previous research, this study provides the first description of the carbon isotopic composition of whole leaf and phytolith-occluded carbon from a number of modern New Zealand endemic plants, and their fossil relatives over the last 120,000 years.

\subsection{Methods}

A number of grass, tree and fern samples were collected from the Otari Plant Museum, Wellington. The choice of the plant species was based on the most common phytoliths extracted from the Otaraia core (refer Chapter 2), and the most climatically significant. The species selected represent those dominant species in the range of environments that may have existed during a glacial cycle in the southern Wairarapa. Also, the numbers of plant samples were limited to fourteen to ensure they could be analysed within the time-frame of the study.

Pollen and phytolith research has shown that in New Zealand during the extremely cold periods of the last glacial period, tussock grasslands dominated the landscape (McGlone 1988, Carter and Lian 2000). New Zealand's grasslands can be divided into two broad groups, short and long tussock grasslands. Therefore, the physiognomic dominant in the short tussock grasslands, Festuca novae zelandiae and in tall-tussock grassland, Chionochloa rubra (Connor and Macrae 1969) were used. For a grass found in forests, forest margins and scrub Anementhele lessoniana was used (Edgar and Connor 1999). All endemic Nothofagus species were included in this study because of the emphasis placed on this genus by McGlone and others. Pollen evidence shows that Nothofagus spp. was the dominant forest tree throughout the last glacial cycle in New Zealand (McGlone 1988). Moreover, as well as the dominance of tussock-grasslands during the coldest periods, there is evidence for substantial patches of Nothofagus forests throughout the North Island during the Last Glacial Maximum (LGM) (McGlone 1985, McGlone et al. 1996). As the climate warmed after the LGM, forests of conifer (Podocarp) and broadleaf trees spread 
throughout New Zealand from refugia to become the dominant vegetation. These forests either dominated or were a major component of the plant cover during the last interglacial (McGlone 1988), and during warmer interstadials during the last glacial cycle. The structure of conifer/broad leaf forests are of an upper tier of podocarps, which may be continuous, scattered or absent and a lower tier of broad-leaved trees of various density (Wardle 1991). Therefore, the two most common podocarp species Dacrydium cupressinum (rimu) and Dacrycarpus dacrydiodes (kahikatea) are included in this study. Also included are the broad-leaved species Beilschmiedia tawa, Knightia excelsa and Weimmannia racemosa. Two tree fern species Cyathea medularis and Cyathea dealbata are also included. However, it should be noted that fern phytoliths make up less than $3 \%$ of phytolith assemblages from ancient sediments (Carter and Lian 2000, Carter 2002, and those presented in Chapter 2 of this study).

A pilot-study was conducted to look at the feasibility of the proposed method of extracting an atmospheric carbon isotope record from phytolith-occluded carbon. Carbon isotopes were measured for whole plant material and the phytolith-occluded carbon extracted from the same material, and the differences were calculated, representing the fractionation effect between the plant and the phytolith. The grass species used in this pilot-study were Chionochloa rubra and Festuca novaezelandiae. Two other samples of one other grass species Bromus madritensis are included. The Bromus sp., were grown under differing $\mathrm{CO}_{2}$ concentrations in the United States as part of a different experiment (Smith et al. 2000) and their phytoliths extracted and analysed in Wellington as part of this study. Tree species were Nothofagus fusca, Nothofagus solandri var solandri, Dacrycarpus dacrydiodes and Knightia excelsa. The tree-fern species were Cyathea medularis and Cyathea dealbata (Table 3.1 and Fig. 3.4). The New Zealand plants used in this pilot study were collected from Otari Plant Museum, Wellington, in 2002.

Following pilot study analysis it was decided to resample some of the plants used in the pilot study and collect other specimen, increasing the number of plants sampled to fourteen. To investigate possible seasonal differences in isotopic fractionation, two suites of twelve samples were collected in summer, (24 February 2003 ) and again in winter (20 August 2003). Each plant suite contained the 
following species, collected from Otari Plant Museum; grasses: Chionochloa rubra, Festuca novae zelandiae, Anementhele lessoniana, and trees: Nothofagus fusca, Nothofagusa solandri var solandri, Nothofagusa solandri var cliffortioides, Nothofagusa menziesii, Nothofagus truncate, Dacrydium cupressinum, Dacrycarpus dacrydiodes, Beilschmiedia tawa and Weimmannia racemosa. To maintain consistency, the same plants were sampled for each suite (Table 3.2 and Fig. 3.5). Because of the small percentages of tree fern phytoliths found in the ancient phytolith assemblages extracted from sediments, none were sampled (Carter and Lian 2000, Carter 2002 and Chapter 2).

\subsubsection{Sample Preparation and Phytolith Extraction from Modern Plant Material for ${ }^{13} \mathrm{C}$ Analysis}

Sample leaves were rinsed once in distilled $\mathrm{H}_{2} \mathrm{O}$ and then ultrasonicated to remove any adhering material. The leaves were then rinsed in $1 \mathrm{~N} \mathrm{HCl}$ (hydrochloric acid) and rinsed three times in distilled $\mathrm{H}_{2} \mathrm{O}$ to ensure removal of all adhering material. The samples were then dried in oven at $70^{\circ} \mathrm{C}$ and weighed. The sample was then split into two sub-samples, one for whole leaf $\delta^{13} \mathrm{C}$ analysis and the other for phytolith extraction for occluded-carbon analysis of $\delta^{13} \mathrm{C}$. The phytoliths were extracted from the plant matter using a wet oxidation method from Geiss (1973). A 2 to 8 gm dry weight of sample was weighed and digested in a flask with concentrated $\mathrm{H}_{2} \mathrm{SO}_{4}$ (sulphuric acid) in a water bath for a least 4 hours at $80^{\circ} \mathrm{C}$. The digestion flask was cooled to room temperature, and then returned to the hot plate, and $30 \% \mathrm{H}_{2} \mathrm{O}_{2}$ (hydrogen peroxide) was added gradually until the liquid was clear and colourless. The phytoliths were concentrated and washed by centrifuging at $5000 \mathrm{rpm}$ for 5 minutes, the supernatant poured off, and the process repeated four times. The recovered phytoliths were then dried at $40^{\circ} \mathrm{C}$. The centrifuge tube was uncapped and covered in a way that allows evaporated air to be expelled, while stopping dust contamination. When dried the sample is sealed and weighed. 


\subsubsection{Carbon Isotope Analysis}

The carbon isotopes of the phytolith samples were measured on the Institute of Geological and Nuclear Sciences Europa Geo 20/20 isotope mass spectrometer. The instrument is interfaced to an ANCA-SL element analyser in continuous flow mode. Around $17 \mathrm{mg}$ of phytolith and $5 \mathrm{mg}$ of plant material were weighed in duplicate into tin capsules for automated combustion. The carbon dioxide generated from the combustion of the organic material was analysed for isotopic abundance as well as total organic carbon. Standards and blanks were included during the run for internal calibration. All results are reported as per mil (\%o) relative to the carbon isotopic composition of Europa scientific flour reference that has been normalised to Vienna PeeDee Belmenite (VPDB) using National Bureau of Standards (NBS)-22. Reproducibility of results was within $0.1 \%$ for carbon.

The first analysis showed that the tin capsules could not hold enough phytoliths to generate sufficient $\mathrm{CO}_{2}$ for analysis. A larger container was devised for the whole of the phytolith sample in the form of a quartz glass tube. Carbon dioxide gas was generated within the tube, which was then broken to release the gas and transferred by gas line to the analyser.

\subsection{Results}

\subsubsection{Pilot Study}

The initial pilot study comprised 11 modern plant samples. For the purpose of this study whole plant material is understood to be leaf and stem of the grass samples, and leaf and less than 5\% stalk of the tree/samples. The grass leaves and stems produced between 0.9 and $3.6 \%$ phytoliths by weight, with a weight percent carbon between 0.5 and $0.2 \%$. The phytolith yield from tree species (less than $5 \%$ stalks and small twigs), was between 0.4 and $2.2 \%$, with a weight percent carbon between 0.5 and $0.3 \%$. The phytolith yield from tree fern species Cyathea medullaris and Cyathea dealbata was respectively $2.8 \%$ and $8.3 \%$ by weight and a weight percent carbon of $0.1 \%$ for both species (Table 3.1 and Fig. 3.4). 


\section{$\delta{ }^{13} \mathbf{C} \%$}

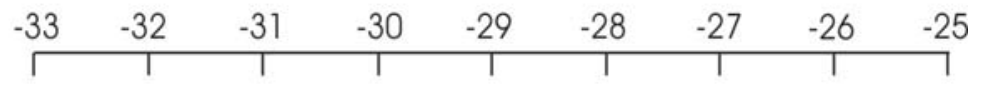

Festuca novae-zelandiae (CIT4)

Chionochloa rubra (CIT3)

Chionochloa rubra (CIT5)

Agropyron smithii

Bromus madritenis (Bm550)

Bromus madritenis (Bm374)

Nothofagus fusca (CIT6)

Nothofagus solandri var solandri (CIT7)

Dacrycarpus dacrydioides (CIT8)

Knightia excelsa (CIT9)

Cyathea medullaris (CIT10)

Cyathea dealbata (CIT11)

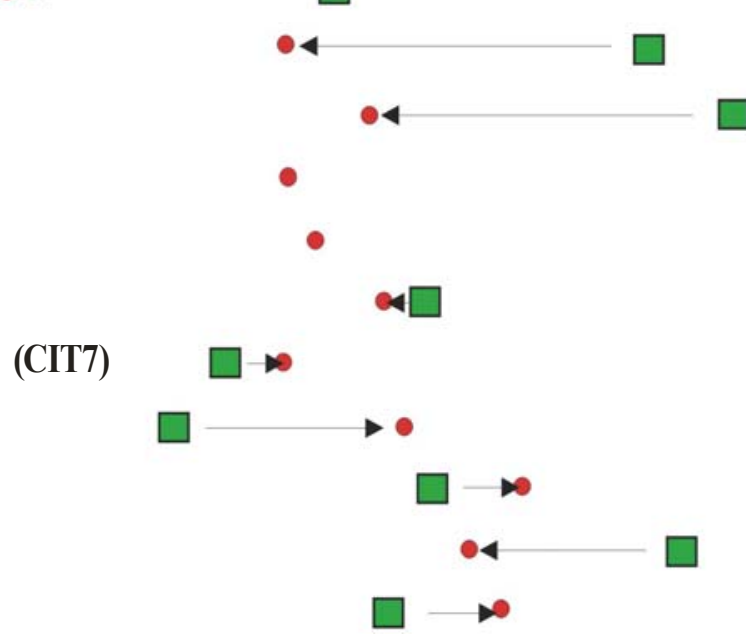

Figure 3.4: Pilot study of $\delta^{13} \mathrm{C} \%$ fractionation between plant material and phytoliths occluded carbon extracted from the same plant material. Green squares indicate $\delta^{13} \mathrm{C} \%$ of modern whole plant material, red dots indicate $\delta^{13} \mathrm{C} \%$ of phytolithoccluded carbon from the same material. Arrows indicate the direction of fractionation, either more negative or less negative. Agropyron smithii results in red from (Kelly et al. 1991) are included for comparison. 
Table 3.1: Pilot study results from analyses of percentage carbon $\delta^{13} \mathrm{C}$ for phytoliths and whole plant material from living grasses, tree-ferns and trees.

\begin{tabular}{|c|c|c|c|c|c|c|c|c|}
\hline & Sample & $\begin{array}{c}\text { Dry } \\
\text { Plant (g) }\end{array}$ & $\begin{array}{c}\text { Phytolith } \\
\text { (g) }\end{array}$ & $\begin{array}{l}\text { Phytolith } \\
(\%)\end{array}$ & $\begin{array}{l}\text { Carbon } \\
(\%)\end{array}$ & $\begin{array}{l}\text { Carbon } \\
(\mu \mathrm{g})\end{array}$ & $\begin{array}{c}\text { Plant } \\
\left(\delta^{13} \mathrm{C} \% \mathrm{o}\right)\end{array}$ & $\begin{array}{c}\text { Phytolith } \\
\left(\delta^{13} \mathrm{C} \% \text { o }\right)\end{array}$ \\
\hline \multirow{5}{*}{ שุ้ } & $\begin{array}{l}\text { F. novae- } \\
\text { zealandiae } \\
\text { (CIT 4) }\end{array}$ & 5.548 & 0.0364 & 1.5 & 0.145 & 121 & $\begin{array}{l}-26.85 \\
\text { (Fn 1) }\end{array}$ & $\begin{array}{c}-30.55 \\
\text { (CIT 4) }\end{array}$ \\
\hline & $\begin{array}{c}\text { Chonochloa } \\
\text { rubra } \\
\text { (CIT3) } \\
\end{array}$ & 4.171 & 0.0364 & 0.87 & 0.53 & 193 & $\begin{array}{c}-29.6 \\
(C R 2)\end{array}$ & $\begin{array}{c}-32.45 \\
\text { (CIT 3) }\end{array}$ \\
\hline & $\begin{array}{c}\text { Chionochloa } \\
\text { rubra } \\
\text { (CIT5) } \\
\end{array}$ & 3.18 & 0.1133 & 3.56 & 0.145 & 164 & $\begin{array}{c}-26.8 \\
(C R 3)\end{array}$ & $\begin{array}{c}-29.95 \\
\text { (CIT 5) }\end{array}$ \\
\hline & $\begin{array}{c}\text { Bromus m. } \\
(550 \%)\end{array}$ & 3.19 & 0.1537 & 4.82 & 0.135 & 207 & N/A & -30.0 \\
\hline & $\begin{array}{c}\text { Bromus m. } \\
(374 \% \text { ) }\end{array}$ & 1.265 & 0.087 & 6.88 & 0.185 & 161 & N/A & -29.75 \\
\hline \multirow{4}{*}{ 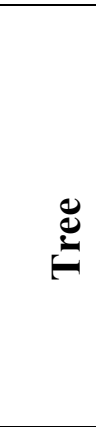 } & $\begin{array}{c}\text { Nothofagus } \\
\text { fusca } \\
\text { (CIT 6) }\end{array}$ & 5.08 & 0.1118 & 2.2 & 0.215 & 240 & $\begin{array}{c}-28.8 \\
(\mathrm{NF} 1)\end{array}$ & $\begin{array}{c}-29.15 \\
\text { (CIT 6) }\end{array}$ \\
\hline & $\begin{array}{c}\text { Nothofagus } \\
\text { solandri var } \\
\text { solandri } \\
\text { (CIT7) }\end{array}$ & 5.017 & 0.1075 & 2.14 & 0.47 & 505 & $\begin{array}{l}-30.55 \\
\text { (NF 2) }\end{array}$ & $\begin{array}{c}-30.05 \\
\text { (CIT 7) }\end{array}$ \\
\hline & $\begin{array}{c}\text { Dacrycarpus } \\
\text { dacrydiodes } \\
\text { (CIT 8) }\end{array}$ & 8.3098 & 0.0338 & 0.41 & 2.32 & 784 & $\begin{array}{c}-31.0 \\
\text { (DD 1) }\end{array}$ & $\begin{array}{c}-29.0 \\
\text { (CIT 8) }\end{array}$ \\
\hline & $\begin{array}{c}\text { Knightia } \\
\text { excelsa } \\
\text { (CIT 9) }\end{array}$ & 8.6552 & 0.0849 & 0.98 & 0.28 & 238 & $\begin{array}{l}-28.75 \\
(K E 1)\end{array}$ & $\begin{array}{c}-27.95 \\
\text { (CIT 9) }\end{array}$ \\
\hline \multirow{2}{*}{$\underbrace{1}=$} & $\begin{array}{l}\text { Cyathea } \\
\text { medularis } \\
\text { (CIT10) }\end{array}$ & 6.17 & 0.1742 & 2.82 & 0.115 & 200 & $\begin{array}{c}-26.6 \\
\text { (CM 1) }\end{array}$ & $\begin{array}{c}-28.4 \\
\text { (CIT 10) }\end{array}$ \\
\hline & $\begin{array}{l}\text { Cyathea } \\
\text { dealbata } \\
\text { (CIT11) }\end{array}$ & 5.9907 & 0.4962 & 8.28 & 0.115 & 571 & $\begin{array}{l}-29.15 \\
\text { (CD 1) }\end{array}$ & $\begin{array}{c}-28.15 \\
\text { (CIT11) }\end{array}$ \\
\hline
\end{tabular}

Carbon isotope measurements $\left(\delta^{13} \mathrm{C} \%\right.$ ) for whole plant material and phytoliths extracted from sub samples of the same plant material showed varying degrees of $\delta^{13} \mathrm{C} \%$ fractionation (Table 3.1, Fig. 3.4 and Appendix 5). Generally the fractionation was larger and more negative in the grass species than in tree and tree fern species. The Festuca novae-zelandiae (CIT4) whole plant carbon averaged $26.85 \%$ and phytolith carbon $-30.55 \%$, a negative fractionation of $-3.7 \%$. Results were different from the two Chionochloa rubra specimens, although the effect was similar in magnitude and direction. Chionochloa rubra (CIT3) whole plant carbon averaged $-29.6 \%$ and phytolith carbon averaged $-32.45 \%$, a negative fractionation of -2.85\%. The Chionochloa rubra (CIT5) whole plant carbon averaged -26.8\%o and phytolith carbon $-29.95 \%$, resulting in a negative fractionation of $-3.15 \%$.

Fractionation in the tree species was in some cases being positive (toward less negative values) and in others negative (toward more negative values). Nothofagus fusca (CIT6) showed a negative fractionation of $-0.35 \%$, whereas, 
Nothofagus solandri var solandri (CIT7), Dacrycarpus dacrydiodes (CIT8), and Knightia excelsa (CIT9) all showed a positive fractionation of $-0.5 \%,-2.0 \%$, and $0.8 \%$ respectively. Fractionation of $\delta^{13} \mathrm{C} \%$ in tree fern species had values between grass and tree species, both positive and negative. Cyathea medullaris (CIT10) whole plant carbon averaged $-26.6 \%$ and phytolith carbon $-28.4 \%$, a negative fractionation of $-1.8 \%$. In contrast, Cyathea dealbata (CIT11) whole plant carbon averaged -29.15 and phytolith carbon $-28.15 \%$, with a positive fractionation of $1.0 \%$.

\subsubsection{Main Study Results}

The results from the main study are very similar to those of the pilot study. Carbon isotope measurements $\left(\delta^{13} \mathrm{C} \%\right.$ ) for whole plant material and phytoliths extracted from sub samples of the same plant material showed varying degrees of $\delta^{13} \mathrm{C} \%$ fractionation (Table 3.2, Fig. 3.5 and Appendix 6). Similarly, the fractionation was larger and more negative in the grass samples than those of the of the tree samples. All samples used in the main study, were sampled twice, once in the Austral summer and labelled [Species name \#1] which were collected on 24/2/2003, and again in the Austral winter and labelled [Species name \#2] which were collected on $20 / 8 / 2003$.

All three grass samples Festuca novae-zelandiae, Chionochloa rubra and Anementhele lessoniana showed greater fractionation between the whole plant carbon and the phytolith carbon, with a mean fractionation of 3.0\% Moreover, the grass samples collected in the Austral summer showed a greater separation between the whole plant material and the phytolith carbon than those collected in the Austral winter.

The results from the nine tree samples are subdivided into 5 Nothofagus species (N. fusca, N. solandri var solandri, N. solandri var cliffortiodes, N. menziesii, N. truncata), Podocarpaceae tree species (Dacrydium cupressinum and Dacrycarpus dacrydiodes) and two broad leaf species. (Beilschmedia tawa and Weimannia racemosa). Fractionation in the tree species was smaller and sometimes positive and at other times negative, with one very large positive fractionation. All tree groups 
had some analysis results showing positive fractionation and some showing negative fractionation. Overall most of the analyses recorded a slight positive fractionation, with a mean fractionation of $1.2 \%$.

Table 3.2: Record of plant species from the main study, sample weight, phytolith weight, phytolith percentage carbon percentage, carbon weight, plant $\delta^{13} \mathrm{C}$, phytolith $\delta^{13} \mathrm{C}$.

\begin{tabular}{|c|c|c|c|c|c|c|c|c|}
\hline \multirow{7}{*}{ 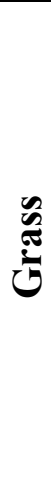 } & Sample Name & $\begin{array}{l}\text { Dry Plant } \\
\text { (g) }\end{array}$ & $\begin{array}{l}\text { Phytolith } \\
\text { (g) }\end{array}$ & $\begin{array}{c}\text { Phytolith } \\
(\%)\end{array}$ & $\begin{array}{c}\text { Carbon } \\
(\mu \mathrm{g})\end{array}$ & $\begin{array}{c}\text { Carbon } \\
(\%)\end{array}$ & $\begin{array}{l}\text { Plant } \\
\left(\delta^{13} \mathrm{C}\right)\end{array}$ & $\begin{array}{c}\text { Phytolith } \\
\left(\delta^{13} \mathrm{C}\right)\end{array}$ \\
\hline & $\begin{array}{c}\text { F. novae-zelandiae } \\
\text { (F.nz-P) }\end{array}$ & 9.3236 & 0.3705 & 3.97 & $26 \mu \mathrm{g}$ & 0.07 & -28.43 & -31.6 \\
\hline & $\begin{array}{c}\text { F. novae-zelandiae } \\
\text { (F.nz2 [P]) }\end{array}$ & 9.5108 & 0.3607 & 3.8 & $217 \mu \mathrm{g}$ & 0.07 & -27.89 & -30.8 \\
\hline & $\begin{array}{l}\text { C. rubra } \\
\text { (C.r-P) }\end{array}$ & 17.9224 & 0.2457 & 0.54 & $958 \mu \mathrm{g}$ & 0.39 & -29.72 & -33.1 \\
\hline & $\begin{array}{l}\text { C. rubra } \\
\text { (C.r2 }[\mathrm{P}])\end{array}$ & 10.9528 & 0.0961 & 0.88 & $96 \mu \mathrm{g}$ & 0.10 & -29.2 & -30.22 \\
\hline & $\begin{array}{c}\text { Anementhele } \\
\text { lessoniana } \\
\text { (A.l.-P) }\end{array}$ & 11.0838 & 0.0852 & 0.77 & $818 \mu \mathrm{g}$ & 0.96 & -28.39 & -34.0 \\
\hline & $\begin{array}{c}\text { Anementhele } \\
\text { lessoniana (A.1.2 [P]) }\end{array}$ & 10.4829 & 0.2825 & 2.7 & $283 \mu \mathrm{g}$ & 0.10 & -30.04 & -31.81 \\
\hline \multirow{18}{*}{$\underset{0}{\mathscr{U}}$} & $\begin{array}{l}\text { Nothofagus fusca } \\
\text { (N.f.-P) }\end{array}$ & 9.8259 & 0.0961 & 0.98 & $269 \mu \mathrm{g}$ & 0.28 & 29.92 & -29.3 \\
\hline & $\begin{array}{c}\text { Nothofagus fusca } \\
\text { (N.f.2 [P]) }\end{array}$ & 10.67 & 0.1517 & 1.42 & $197 \mu \mathrm{g}$ & 0.13 & -29.73 & -29.25 \\
\hline & $\begin{array}{c}\text { Nothofagus solandri } \\
\text { var solandri } \\
\text { (N.s.s.-P) } \\
\end{array}$ & 10.1996 & 0.1089 & 1.07 & $163 \mu \mathrm{g}$ & 0.15 & -30.05 & -27.2 \\
\hline & $\begin{array}{c}\text { Nothofagus solandri } \\
\text { var solandri } \\
\text { (N.s.s.2 [P]) } \\
\end{array}$ & 10.6192 & 0.2067 & 1.95 & $455 \mu \mathrm{g}$ & 0.22 & -29.32 & -29.96 \\
\hline & $\begin{array}{c}\text { Nothofagus solandri } \\
\text { var cliffortiodes } \\
\text { (N.s.c.-P) }\end{array}$ & 11.2618 & 0.0922 & 0.82 & $156 \mu \mathrm{g}$ & 0.17 & -30.71 & -28.0 \\
\hline & $\begin{array}{c}\text { Nothofagus solandri } \\
\text { var cliffortiodes } \\
\text { (N.s.c.2 [P]) }\end{array}$ & 11.7163 & 0.1683 & 1.44 & $236 \mu \mathrm{g}$ & 0.14 & -29.71 & -27.43 \\
\hline & $\begin{array}{c}\text { Nothofagus menziesii } \\
\text { (N.m.-P) }\end{array}$ & 10.9348 & 0.0120 & 0.11 & $7 \mu \mathrm{g}$ & 0.06 & -30.86 & -29.24 \\
\hline & $\begin{array}{c}\text { Nothofagus menziesii } \\
\text { (N.m.2 [P]) }\end{array}$ & 11.0623 & 0.1107 & 1.00 & $255 \mu \mathrm{g}$ & 0.23 & -27.18 & -29.12 \\
\hline & $\begin{array}{c}\text { Nothofagus truncata } \\
\text { (N.t.-P) }\end{array}$ & 10.6210 & 0.1106 & 1.04 & $144 \mu \mathrm{g}$ & 0.13 & -29.00 & -29.1 \\
\hline & $\begin{array}{c}\text { Nothofagus trunca } \\
\text { (N.f.2 }[\mathrm{P}])\end{array}$ & 10.7985 & 0.0136 & 0.13 & $830 \mu \mathrm{g}$ & 0.61 & -29.38 & -23.53 \\
\hline & $\begin{array}{c}\text { Dacrydium } \\
\text { cupressinum (D.c. P) }\end{array}$ & 11.2481 & 0.2508 & 2.23 & $2107 \mu \mathrm{g}$ & 0.84 & -30.28 & -31.85 \\
\hline & $\begin{array}{c}\text { Dacrydium } \\
\text { cupressinum (D.c.2 [P]) }\end{array}$ & 10.4809 & 0.0431 & 0.41 & 892 & 2.07 & -30.68 & -27.63 \\
\hline & $\begin{array}{c}\text { Dacrycarpus } \\
\text { dacrydiodes (D.d.-P) }\end{array}$ & 11.6268 & 0.0092 & 0.08 & $64 \mu \mathrm{g}$ & 0.70 & -30.06 & -26.7 \\
\hline & $\begin{array}{l}\text { Dacrycarpus } \\
\text { dacrydiodes } \\
\text { (D.d.2 [P]) } \\
\end{array}$ & 10.5213 & 0.0268 & 0.25 & 1099 & 4.1 & -29.77 & -27.34 \\
\hline & $\begin{array}{c}\text { Beilschmiedia tawa } \\
\text { (B.t.-P) }\end{array}$ & 18.6972 & 0.1135 & 0.61 & $704 \mu \mathrm{g}$ & 0.62 & -29.26 & -30.5 \\
\hline & $\begin{array}{c}\text { Beilschmiedia tawa } \\
\text { (B.t.2 [P]) }\end{array}$ & 8.4676 & 0.1876 & 2.22 & $150 \mu \mathrm{g}$ & 0.08 & -30.94 & -28.43 \\
\hline & $\begin{array}{c}\text { Weimmannia racemosa } \\
\text { (W.r.-P) }\end{array}$ & 10.4380 & 0.0458 & 0.44 & $2290 \mu \mathrm{g}$ & 5.0 & -28.10 & -27.98 \\
\hline & $\begin{array}{c}\text { Weimmannia racemosa } \\
\text { (W.r.2 }[\mathrm{P}])\end{array}$ & 10.8584 & 0.0111 & 0.10 & $9 \mu \mathrm{g}$ & 0.08 & -29.16 & -27.61 \\
\hline
\end{tabular}



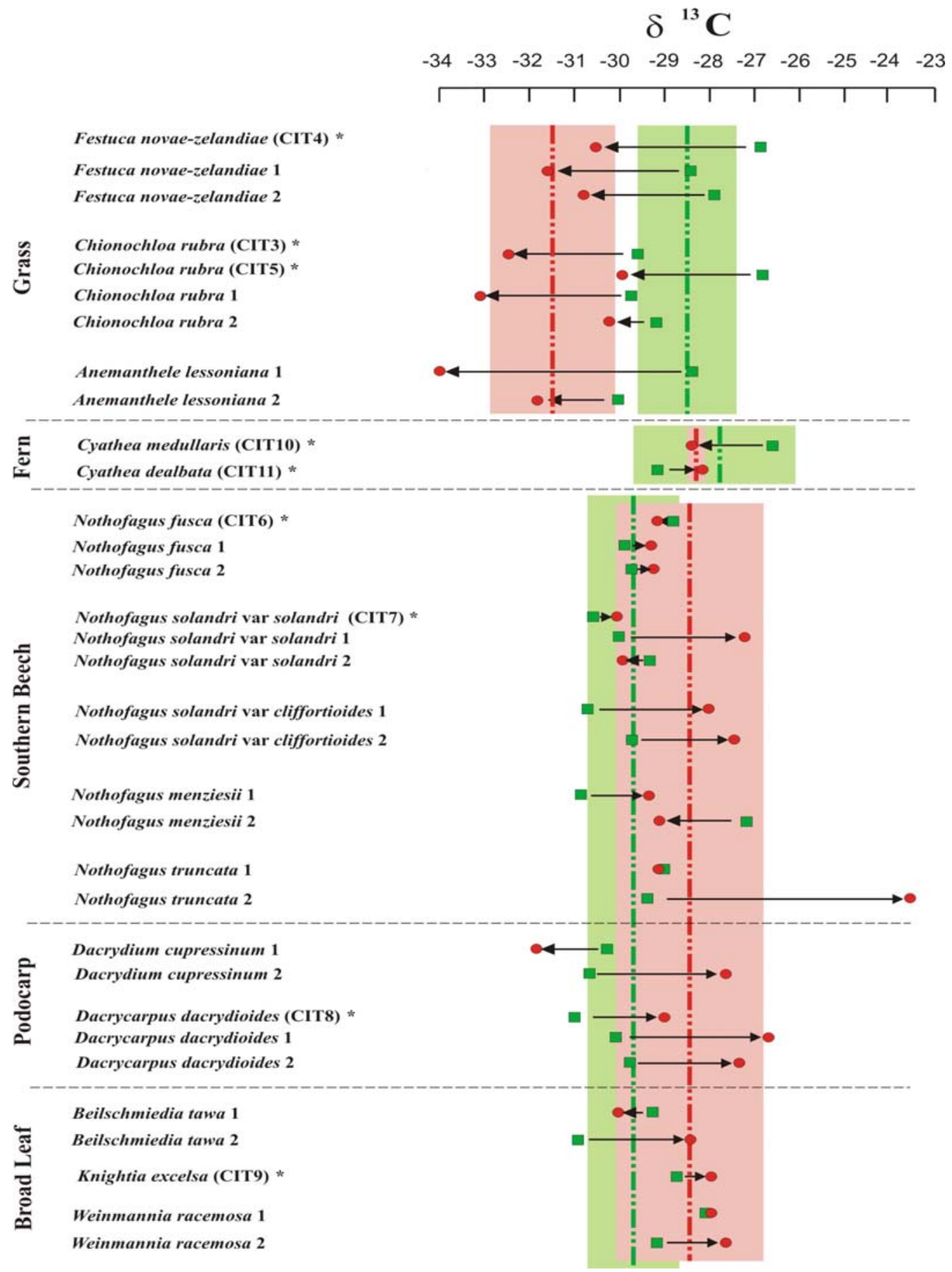

Fig. 3.5: Combined carbon isotope analysis records from all New Zealand plant species, (pilot and main study). Small green squares indicate $\delta^{13} \mathrm{C} \%$ of modern whole plant material and small red dots indicate $\delta^{13} \mathrm{C} \%$ of phytolith-occluded carbon from the same material. Arrows indicate the direction of fractionation, either more negative or less negative. Samples labelled 1 were collected in summer, and samples labelled 2 were collected in winter. One standard deviation is shown by the red band (phytolith) and green band (whole plant tissue). Mean $\delta^{13} \mathrm{C}$ values of phytoliths are shown by a red broken line and whole plant tissue by a green broken line. The species from the pilot study are denoted with an *. 
When both the pilot and the main data sets were combined the averaged grass whole plant material gave a carbon isotopic value of $-28.5 \%$, and a standard deviation of $1.2 \%$. Grass phytolith-occluded carbon average value was $-31.5 \%$, and a standard deviation of $1.4 \%$ (n 9). The average difference (average fractionation effect) between grass whole plant material and phytolith-occluded carbon) was 3.0\%o. Average whole plant material values of trees were $-29.7 \%$ and a standard deviation $0.97 \%$. Tree phytolith-occluded carbon average value was -28.5 with a standard deviation of $1.7 \%$ o $(n 22)$. The average fractionation effect between tree whole plant material and phytolith-occluded carbon) was 1.2\%o. An average whole plant material value of tree ferns was $-27.9 \%$ and a standard deviation $1.8 \%$. Tree fern phytolith-occluded carbon average value was -28.3 with a standard deviation of $0.2 \%$ ( $n$ 2). The average fractionation effect between tree whole plant material and phytolith-occluded carbon was $0.4 \%$ (Table 3.2 and Fig. 3.5 )

\subsubsection{Carbon Compounds Present Within Phytolith-Occluded Carbon}

These results and previous studies (Wilding et al. 1967, Kelly et al. 1991, Fredlund, 1993, Smith and Anderson, 2001, Smith and White, 2004) suggest that some of the fractionation differences between whole plant material and phytolithoccluded carbon are related to differences in the proportions and concentrations of the various carbon compounds. The results from this study show similar fractionations in $\delta^{13} \mathrm{C}$ recorded between whole plant material and phytolith-occluded carbon Also there are differences in $\delta^{13} \mathrm{C}$ fractionation recorded in phytolithoccluded carbon from grasses and trees (Figs. 3.2 and 3.3). The chemical composition of compounds present within phytoliths is not well known and there have been a number of attempts to document the full range and concentrations of these compounds. Aromatic compounds such as lignin were indicated by diffused reflectance Fourier transform infrared spectroscopy (Kelly et al. 1991). However, when Smith and Anderson, (2001) used a TMAH thermochemolysis and GC-MS analysis technique, (a technique particularly suited to characterising lignin), no lignin was recorded. Instead, the analysis recorded the presence of lipids (fatty acid methyl esters), fatty alcohols $\left(\mathrm{C}_{\mathrm{n}} \mathrm{OH}\right)$ and straight chain hydrocarbons $\left(\mathrm{C}_{\mathrm{n}} \mathrm{HC}\right)$. However, this technique is limited because of its inability to detect carbohydrates such as cellulose or hemicellulose. Carbohydrates which comprise $57-77 \%$ of the weight of 
dry plant tissue can either be enriched by $1-2 \%$ or depleted by $1-4 \%$ (Smith and Anderson 2001).

The identification of lipids in phytolith-occluded carbon helps in explaining the fractionation between phytoliths and whole plant material. However, until the occluded carbohydrates are able to be documented, a full explanation remains elusive. One technique potentially able to fully document carbon compounds in plant material is Nuclear Magnetic Resonance (NMR). However, Kelly et al. (1991) reported that NMR experiments have proved inconclusive due to the low carbon concentration in phytoliths. Because analytical techniques are being constantly improved two phytolith samples were sent to Warwick University for NMR analysis. The samples included one from Festuca novae-zelandiae (grass) (FNTMT 165900) and from Nothofagus solandri (tree) (NSMT 165745).

The spectrum from FNTMT 165900 (grass) provides evidence of a mix of saturated (often $15 \mathrm{ppm}$ upwards to around $60 \mathrm{ppm}$ ) and unsaturated centres, carbonyl compounds (e.g. ketones, carboxylic acids and esters, typically around 170$220 \mathrm{ppm}$ ). The bulk of the peak is around 100-160 ppm, which is the region of alkenes and aromatics. The spectrum in NSMT 165175 (tree) represents mostly saturated carbon. The peaks with chemical shifts around 25-45 ppm are typical of aliphatic carbons with little electronegative attached e.g. $\mathrm{C}$ attached to at least two other $\mathrm{C}$ with the rest $\mathrm{H},(\mathrm{R} 2 \underline{\mathrm{CH}}, \mathrm{R} 3 \underline{\mathrm{CH}})$ or a carbon attached to a carbonyl group (as

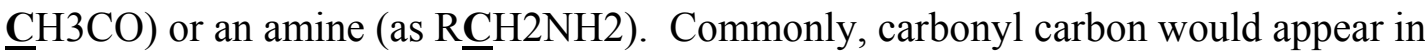
the $13 \mathrm{C}$ NMR at around $200 \mathrm{ppm}$. The carbon was in the form of amines or as primary tertiary alkanes $(\mathrm{R} 3 \underline{\mathrm{CH}})$. (K. MacKenzie Victoria University of Wellington pers com) (Fig. 3.6). 


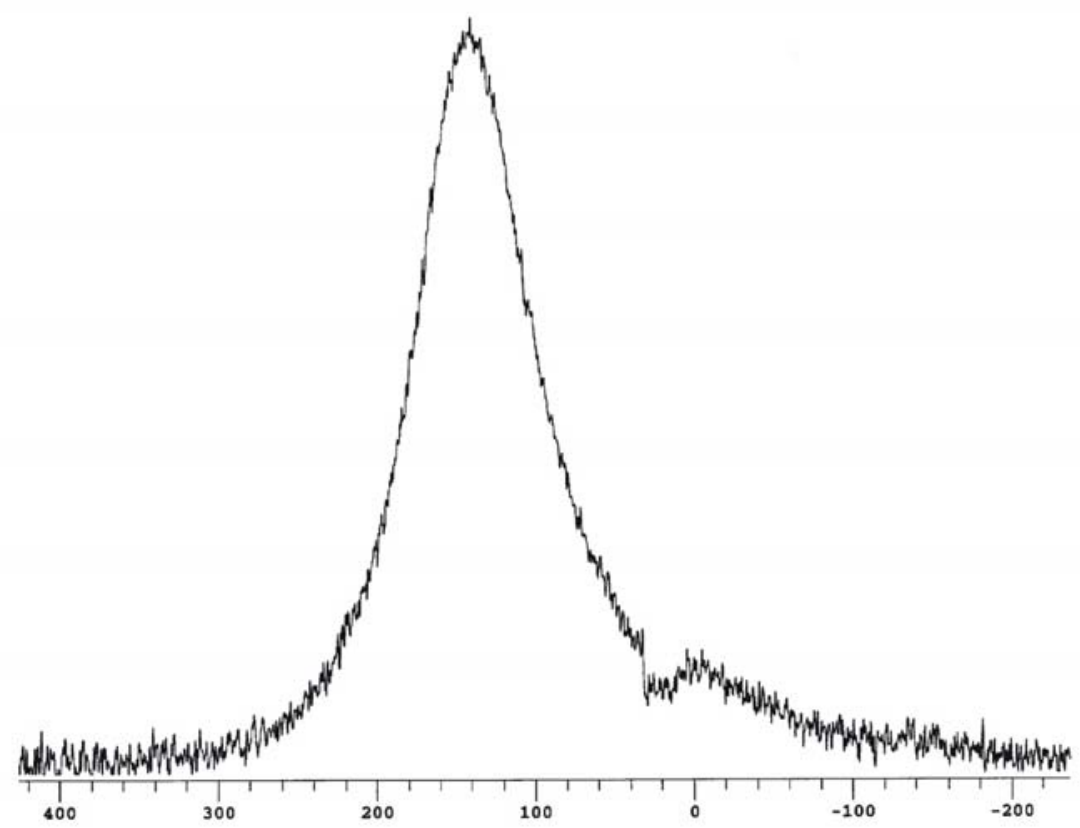

FNTMT 165900 (Festuca novae-zelandiae)

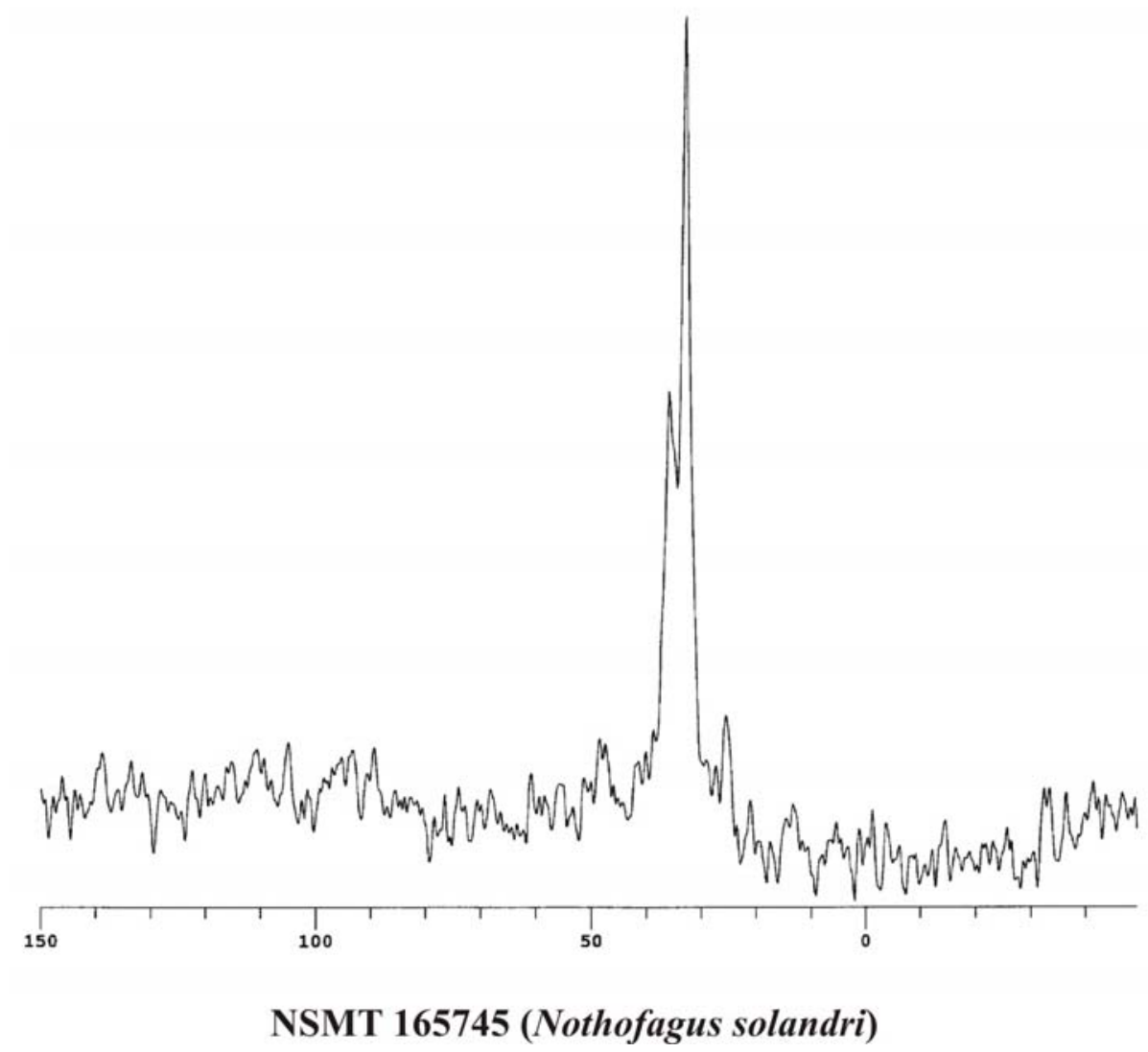

Fig. 3.6: NMR spectra of Festuca novae-zelandiae (grass) (FNTMT 165900) and one extracted from Nothofagus solandri (tree) (NSMT 165745). All values are in per mil. 
The NMR spectra demonstrate a distinct difference in the types of carbon composition of phytolith-occluded carbon from the two plants. However, the identity of the compounds cannot be determined. The NMR approach appears promising, but needs further research to better understand the range and concentrations of compounds present within phytolith-occluded carbon. Such research is beyond the scope of the present project.

\subsection{Discussion}

The pilot study of nine native plants raised a number of questions. 1) Were the differences between the grass results showing all negative fractionation and the tree results showing both positive and negative fractionation, caused by analytical or processing error? Or were they repeatable? 2) Were the differences in the two Chionochloa rubra results caused by a seasonal difference or caused by an analytical or processing error? Or were they repeatable? To answer these questions the main study was conducted, including five of the species of the pilot study and seven other specimens, increasing the number of plant samples to twelve. In general there is good agreement when comparing the results from the two experiments of this study with those of other workers (Kelly et al. 1991, Smith and Anderson 2001, Smith and White 2004). However, it should be noted that plants analysed in these studies recorded carbon isotopes from only grass species and the phytoliths contained within, and did not consider those from tree or fern species.

\subsubsection{Comparison with Previous Work and Samples Grown Under Different $\mathrm{CO}_{2}$ Concentrations}

For comparison the $\delta^{13} \mathrm{C}$ values of a $\mathrm{C}_{3}$ grass from a study by Kelly et al. (1991) are included with those of the pilot study (Table 3.1 and Fig. 3.4). They found that Agropyron smithii whole plant carbon averaged -26.1 ppm and phytolith carbon $-29.3 \mathrm{ppm}$, a negative fractionation of $-3.2 \%$. These values are within the range of this study.

Plants fix atmospheric $\mathrm{CO}_{2}$ using three possible photosynthetic metabolic pathways; these are $\mathrm{C}_{3}, \mathrm{C}_{4}$ or Crassulacean Acid Metabolism CAM. The majority of 
the plant kingdom fixes atmospheric $\mathrm{CO}_{2}$ using the pathway described by Calvin $\left(\mathrm{C}_{3}\right)$, which give them average isotopic values of $-28 \%$. About $5 \%$ of plants, mainly grasses, fix atmospheric $\mathrm{CO}_{2}$ using the Hatch-Slack $\left(\mathrm{C}_{4}\right)$ pathway giving an average isotopic value of $-14 \%$. The third and less common carbon-fixing pathway is the CAM, which is used by a small number arid climate plants, mainly succulents. CAM plants have an isotopic range of $-20 \%$ to $-10 \%$, between those using the $\mathrm{C}_{3}$ and $\mathrm{C}_{4}$ pathways (Hoefs 1987). However, in this study only $\mathrm{C}_{3}$ plants are considered. The vast majority of New Zealand plants are $\mathrm{C}_{3}$ with only two native plants known to have the $\mathrm{C}_{4}$ pathway, two coastal species Atriplex buchananii and Theleophyton billiardierei. There are also two CAM native aquatic plants, Isoetes kirkii and Lilaeopsis novae zelandiae (Wardle 1991). However, because of the very small number of New Zealand native plant species that are not $\mathrm{C}_{3}$ and the almost negliable chance of their phytoliths being included in the phytolith assemblages used in this study, all phytoliths used in this work are assumed to derive from $\mathrm{C}_{3}$ plants.

Grass grown under elevated $\mathrm{CO}_{2}$ concentrations used in an experiment conducted by Smith et al. (2000) was also analysed. Phytoliths were extracted and $\delta^{13} \mathrm{C}$ measurements made of the phytolith-occluded carbon from two Bromus madritensis $\left(\mathrm{C}_{3}\right.$ grass) samples grown under different $\mathrm{CO}_{2}$ concentrations. The results are included in the experimental results Table 3.1 and Fig. 3.4. In one, the plants were grown under elevated $\mathrm{CO}_{2}$ conditions of $550 \mathrm{ppm}$ (BM550). In the other, the plants were grown under ambient $\mathrm{CO}_{2}$ conditions of $374 \mathrm{ppm}$ (BM375). However, because of the small amount of material, it was only possible to analyse the phytolith-occluded carbon and not analyse the whole plant values. No discernable difference is noted between the phytolith-occluded carbon isolated from these two samples. These findings suggest that changes in the concentration of atmospheric $\mathrm{CO}_{2}$ have very little effect on the carbon isotopic fractionation effect between whole plant material and the phytoliths contained within. This is in agreement with Arens et al. (2000) who found no statistically significant relationship between the concentration of atmospheric $\mathrm{CO}_{2}$ and whole plant $\delta^{13} \mathrm{C}$ in an extensive review of research into links between atmospheric $\mathrm{CO}_{2}$ and $\mathrm{C} 3$ plant carbon isotopic composition. This suggests that variation in atmospheric $\mathrm{CO}_{2}$ does not significantly influence the $\delta^{13} \mathrm{C}$ of plant tissue. However, it should be noted that the Arens et al. 
(2000) work looked at whole plant material and this study is concerned with plant phytolith carbon isotopic composition.

\subsubsection{Possible Seasonal Fractionation Effects}

The carbon isotope results from the two Chionochloa rubra samples of the first experiment differed; one Chionochloa rubra (CIT3) was collected on 18/2/2002 while another Chionochloa rubra (CIT5) was collected on 28/6/2002. It was postulated that plants fractionate at different rates between summer and winter. To test this hypothesis a collection of two further suites of samples were collected one in summer 2003 and one in winter 2003 (Tables 3.2, 3.3 and Fig. 3.5).

Table 3.3 Seasonal differences in $\delta^{13} \mathrm{C}$ of whole plant tissue and phytolith-occluded carbon from a number of modern New Zealand endemic grass and tree species.

\begin{tabular}{|c|c|c|c|c|c|c|}
\hline \multirow{7}{*}{ ש̃ } & Summer & $\delta^{13} \mathrm{C}$ Plant & $\delta^{13} \mathrm{C}$ Phytolith & Winter & $\delta^{13} \mathrm{C}$ Plant & $\delta^{13} \mathrm{C}$ Phytolith \\
\hline & F.n.1 (Feb.) & -28.43 & -31.6 & F.n.1 (Aug.) & -27.89 & -30.8 \\
\hline & C.r.1 (Feb.) & -29.72 & -33.1 & C.r.1 (Aug.) & -29.2 & -30.22 \\
\hline & A.1.1 (Feb.) & -28.39 & -34.0 & A.1.1 (Aug.) & -30.04 & -31.81 \\
\hline & Mean & -28.85 & -32.9 & & -29.04 & -30.94 \\
\hline & Std. Dev. & 0.76 & 1.21 & & 1.08 & 0.80 \\
\hline & Seasonal Change & 0.2 & 1.96 & & & \\
\hline \multirow{12}{*}{ 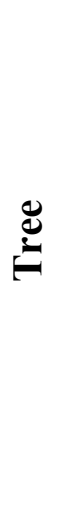 } & N.f.1 (Feb.) & -29.92 & -29.3 & N.f.1 (Aug.) & -29.73 & -29.25 \\
\hline & N.s.s.1 (Feb.) & -30.05 & -27.2 & N.s.s.1 (Aug.) & -29.32 & -29.96 \\
\hline & N.s.c.1 (Feb.) & -30.71 & -28.0 & N.s.c.1 (Aug.) & -29.71 & -27.43 \\
\hline & N.m.1 (Feb.) & -30.86 & -29.24 & N.m.1 (Aug.) & -27.18 & -29.12 \\
\hline & N.t.1 (Feb.) & -29.0 & -29.1 & N.t.1 (Aug.) & -29.38 & -23.53 \\
\hline & D.c.1 (Feb.) & -30.28 & -31.85 & D.c.1 (Aug.) & -30.68 & -27.63 \\
\hline & D.d.1 (Feb.) & -30.06 & -26.7 & D.d.1 (Aug.) & -29.76 & -27.34 \\
\hline & B.t.1 (Feb.) & -29.26 & -30.5 & B.t.1 (Feb.) & -30.94 & -28.43 \\
\hline & W.r.1 (Feb.) & -28.1 & -27.98 & W.r.1 (Aug.) & -29.16 & -27.61 \\
\hline & Mean & -29.8 & -28.1 & & -29.54 & -27.81 \\
\hline & Std. Dev. & 0.87 & 1.62 & & 1.07 & 1.86 \\
\hline & Seasonal Change & 0.26 & 0.29 & & & \\
\hline
\end{tabular}

A small number of seasonal carbon isotope data are available in the literature. However, this body of research reported on seasonal changes in $\delta^{13} \mathrm{C}$ in whole plant material and did not look at seasonal effects in phytolith-occluded carbon (Mooney 1974, Lowden and Dyke 1974, Troughton et al. 1977, Guy, Reid and Krouse 1980, Smith and Osmond 1987, Comstock et al. 1988, Ehleringer and Cooper 1988, Smedley et al. 1991, Ehleringer, Phillips and Comstock 1992). These studies report a general trend of decreasing carbon isotope discrimination as the growing season 
progressed, showing that plant leaves contained less $\delta^{13} \mathrm{C}$ (were more negative) in winter, than summer. Grass whole plant tissue values from this study were in agreement with their findings, in that the winter mean $\delta^{13} \mathrm{C}$ value was $0.2 \%$ more negative that the summer values. In contrast, the grass phytolith-occluded carbon values extracted from the same material are more negative in the summer-harvested material, with a seasonal difference of $\delta^{13} \mathrm{C} 2.0 \%$. The tree whole plant values contrasted with that of the grasses, in that they were more negative in summer than winter, with a seasonal difference of $\delta^{13} \mathrm{C} 0.3 \%$. The tree phytolith-occluded carbon showed a similar trend of more negative values for the summer than the harvested material, with a seasonal difference of $\delta^{13} \mathrm{C} 1.6 \%$.

There are a number of possible reasons for the differences between the findings of the present study and those of others. Firstly, the difference in the seasonal range of atmospheric $\delta^{13} \mathrm{C}$ between the hemispheres (all the above cited studies analysed plant material grown in the Northern Hemisphere). Secondly, the bulk of the carbon measured in this research is remobilised from carbon stored by the plant at the end of the last season and represents a carbon isotope lag between the seasons. Thirdly, all the plants analysed in the cited studies were from deserts or dry climate environments, whereas the plants analysed for this study were from a temperate humid environment. Lastly, it is possible that the range of plant species used in this study is too small and/or does not represent fully the real carbon isotope range of New Zealand native vegetation at $42^{\circ}$ south.

The peak-to-peak amplitude in concentration of the $\mathrm{CO}_{2}$ seasonal cycle in mid-to-high latitudes of the Northern Hemisphere is 10-15 ppm, due to the spring uptake and autumn release of $\mathrm{CO}_{2}$ from the northern land mass (C3) vegetation. For $\mathrm{C} 3$ photosynthesis, the ${ }^{13} \mathrm{C}$ fractionation is about 0.05 per mil per ppm of $\mathrm{CO}_{2}$, i.e. the $\delta^{13} \mathrm{C}$ seasonal variation is about $0.5-0.75$ per mil, in line with $\delta^{13} \mathrm{C}$ observation. In the Southern Hemisphere mid-to-high latitudes, the peak-to-peak seasonal range in $\mathrm{CO}_{2}$ concentration is lower than that of the Northern Hemisphere, because the terrestrial biosphere in the Southern Hemisphere is very small compared to that in the Northern Hemisphere. The measured peak to peak amplitude in $\delta^{13} \mathrm{C}$ at Baring Head is typically 0.05 per mil (Dave Lowe pers com.). It is possible that because of the 
approximately ten-fold difference in seasonal change between the hemispheres, the seasonal effect on plant and phytolith-occluded carbon is less in the Southern than the Northern Hemisphere.

When looking at possible seasonal changes recorded in phytolith-occluded carbon, regard must be given to the timing of fresh leaf growth and the time leaves stay on the tree. It has been noted that there is a difference in the longevity of leaves between Nothofagus species. The leaves of $N$. fusca and N. truncata are strictly annual and are renewed in the spring flush associated with leaf fall. $N$. solandri leaves may live for two years in var. cliffortiodes. In contrast, $N$. menziesii leaves commonly live for three years and have been recorded as having survived for up to five years (Ogden et al. 1996). The phytolith-occluded carbon results for $N$. fusca show a $0.05 \%$ o change between summer and winter, whereas, the phytolith-occluded carbon results for N. trucata show a 5.57\%o change (Table 3.3 and Fig. 3.5). The difference between these two species seems anomalous. If the $N$. trucata results are disregarded there is a possible season signal in the $N$. fusca results, however, because the size of the signal is within the tree phytolith-occluded carbon average means of $0.5 \%$, this remains ambiguous. The $N$. solandri var solandri and $N$. solandri var cliffortiodes all show changes that could possibly be interpreted as seasonal. However, because it is unknown at this stage whether during the longer life of these leaves any isotopic changes take place, it would be imprudent without further research to draw any firm conclusions. The $\delta^{13} \mathrm{C}$ values in grass whole plant tissue of this study do appear show a seasonal effect, but this material differed by $0.34 \%$, whereas the atmosphere differed by $0.05-0.07 \%$. These changes may have been caused by other physiological factors, with a possible as yet undefined amplifying seasonal component. Fractionation in the grass phytolith-occluded carbon is in the opposite direction and probably due to differences in changes in concentrations of different compounds. The fractionation direction is more negative in summer than winter in both tree whole-plant material and phytolith-occluded-carbon. These results run counter to those obtained from Northern Hemisphere material, suggesting that other unknown physiological factors account for the recorded changes.

In conclusion, while at a first approximation there does appear to be some seasonal differences in the $\delta^{13} \mathrm{C}$ values of whole plant and phytolith-occluded carbon, 
all the differences are within the recorded ranges (Table 3.3 and Fig. 3.5). Therefore, any "seasonal changes" present in the ancient record of this study will lie within the normal expected range. At present any linkage between seasonal changes in carbon compounds present within phytolith-occluded carbon remains unknown. Therefore, it would be useful at some future date to research and document the range of carbon compounds present within phytolith-occluded carbon.

\subsubsection{Atmospheric $\delta^{13} \mathrm{CO}_{2}$ from Modern Plant Phytolith-Occluded Carbon}

Arens et al. (2000) reasoned that an atmospheric $\delta^{13} \mathrm{CO}_{2}$ signal could be derived from plant material using the equation of Farquhar et al. (1989). Arens et al. (2000) used a model of carbon isotopic fractionation during C3 photosynthesis, in combination with a large data set (519 measurements from 176 species), to show that the $\delta^{13} \mathrm{C}$ value of atmospheric $\mathrm{CO}_{2}$ can be reconstructed from the isotopic composition of plant tissue. They found that most ( $\mathrm{ca}$. 90\%) of all the variations in $\mathrm{C} 3$ plant $\delta^{13} \mathrm{C}$ values were explained by change in the carbon isotope composition of atmospheric $\mathrm{CO}_{2}$ with a smaller influence from atmospheric $\mathrm{CO}_{2}$ concentration.

They used a subset ( $n$ 119) of their data spanning a geologically reasonable range of atmospheric $\delta^{13} \mathrm{C}$ values (-6.4\% to $-9.6 \%$ ), including data from plants grown under a $\mathrm{CO}_{2}$ range of $225 \mathrm{ppm}$ to $1300 \mathrm{ppm}$, to reconstruct the $\delta^{13} \mathrm{C}$ value of atmospheric $\mathrm{CO}_{2}$ based on plant values. Their equation to determine atmospheric $\delta^{13} \mathrm{CO}_{2}$ from plant $\delta^{13} \mathrm{C}$, is as follows:

Eq. 2: $\delta^{13} \mathrm{CO}_{2}=\left(\delta^{13} \mathrm{C}\right.$ plant $\left.+18.67 \%\right) / 1.10 \%$.

Gröcke (2001) further derived the equation to predict the carbon isotope ratio of atmospheric $\mathrm{CO}_{2}$ :

Eq. 3: $\delta^{13} \mathrm{CO}_{2}$ atmosphere $\%=\delta^{13} \mathrm{C}_{\text {plant }}+a+(b-a) \times\left(p_{i} / p_{a}\right)$.

By substituting the values for $a\left(4.4 \times 10^{-3}\right)$ and $b\left(27 \times 10^{-3}\right)$ into the equation and assuming a modern C3 plant $p_{i} / p_{a}$ ratio of 0.7 (Evans et al. 1986: Polley et al. 1993), he expressed it more simply as 
Eq. 4: $\delta^{13} \mathrm{C}$ air $\%=\delta^{13} \mathrm{C}_{\text {plant }}+20.22 \%$

The results below follow the application of equation (4) on the average modern whole plant leaf tissue carbon analysis results from this study (Table 3.2)

Grass whole leaf tissue mean $-28.50 \%$ (n 9$)+20.22 \%=\quad \delta^{13} \mathrm{C}$ air $\%$ o $=-8.28 \%$ Tree whole leaf tissue mean $-29.70 \%$ (n 22) $+20.22 \%=\quad \delta^{13} \mathrm{C}$ air \%o $=-9.48 \%$ Fern whole leaf tissue mean $=-27.875 \%$ (n 2) $+20.22 \%$ o $=\delta^{13} \mathrm{C}$ air $\%_{0}=-7.68 \%$ Mean $\delta^{13} \mathrm{C}$ air $\%=-8.48 \%$ o

The $\delta^{13} \mathrm{CO}_{2}$ of the atmosphere determined from modern grass tissue is $-8.28 \%$ o and this is in close agreement with the $2002 \delta^{13} \mathrm{C}$ air \%o mean of - 8.02 recorded at Baring Head, New Zealand Dave Lowe (pers com.). However, the lower value for the tree record (-9.48) is anomalous and possibly related to a canopy effect. A canopy effect is the way that a number of factors create conditions which lower $\delta^{13} \mathrm{CO}_{2}$ in the air circulating beneath a forest canopy, which in turn, partially controls the stable carbon isotopic ratio of any plant material photosynthesised beneath that canopy.

Canopy factors include; respired $\mathrm{CO}_{2}$ reducing atmospheric $\delta^{13} \mathrm{C}$ under a closed canopy, changes in light intensity and water-use-efficiency (Vogel 1978, Farquhar et al 1989, Leavitt and Long 1991, Schultz and Adams 1995, West et al. 2001 and Turney et al. 2002). As light intensity drops the ratio of partial pressures of internal $\mathrm{CO}_{2}$ and atmospheric $\mathrm{CO}_{2}$ increases leading to a discrimination against ${ }^{13} \mathrm{C}$. This results in plant leaves that are isotopically light (more negative), and isotopically lighter phytolith-occluded carbon. Therefore, it is reasonable to expect that leaves growing in sunlit areas of the canopy will be isotopically heavier than leaves growing in shaded areas, due to the combined effects of carbon source, light intensity and water use efficiency.

In non-forested environments, it is assumed that turbulent mixing of the air results in air with the same isotopic ratio as the atmosphere. Therefore, in this study it is assumed that grass and fern modern plant samples and the grass and fern 
components of ancient phytolith assemblages, have photosynthesised in air with the same carbon isotopic ratios as the atmosphere at the time these plants were growing.

A literature review revealed a number of studies where $\delta^{13} \mathrm{CO}_{2}$ changes within the canopy have been measured (Vogel 1978, Buchmann et al. 1997, West et al. 2001, Turney et al. 2002). Vogel (1978) analysed Fagus sp. leaves and recorded $\delta^{13} \mathrm{C}$ of $-28.8 \%$ from leaves from $2 \mathrm{~m}$ above the ground and $-31.2 \%$ from leaves 10 $\mathrm{m}$ above the ground, a range of 2.4\% . The Buchman et al. 1997 study showed that the intra-canopy depletion of leaf $\delta^{13} \mathrm{C}$ was lowest in an open stand of trees (1\%o) and greatest in denser stands (4.5\%). West et al. (2001) observed significant depression in leaf $\delta^{13} \mathrm{C}$ values under a closed canopy compared with those from an open or a well-lit canopy, which had less negative $\delta^{13} \mathrm{C}$ values. Turney et al. (2002) measured the $\delta^{13} \mathrm{C}$ of both bulk tissue and lignin of live and senesced leaves of Nothofagus solandri var cliffortiodes from five levels through the canopy. They found that the sunlit leaves were significantly isotopically heavier (3\%) than leaves from deeper within the canopy.

To extract an atmospheric $\delta^{13} \mathrm{CO}_{2}$ signal from both the whole leaf and phytolith-occluded carbon from modern plant records of this study, a canopy constant $(\mathrm{c} / \mathrm{c})$ of $1 \%$ is used, because the tree samples of this study were collected from those growing in semi open situations in Otari Garden, similar to the open stand of the Buchmann et al. (1997) study. The modified equation with added canopy constant (c/c) of $1 \%$ should read:

Eq. 5: $\delta^{13} \mathrm{C}$ air $\%$ o $=\delta^{13} \mathrm{C}_{\text {plant }}+20.22+(\mathrm{c} / \mathrm{c}$ only for tree whole leaf tissue $)$.

This should be applied to modern tree whole leaf tissue and phytolith-occluded carbon measurements to give the following:

Grass whole leaf tissue mean $\quad-28.50(\mathrm{n} 9)+20.22 \%=\quad \delta^{13} \mathrm{C}$ air $\%$ o $=-8.28$

Tree whole leaf tissue mean $=-29.70(\mathrm{n} \mathrm{22})+21.22 \%=\quad \delta^{13} \mathrm{C}$ air \%o $=-8.48$

Fern whole leaf tissue mean $=-27.875(\mathrm{n} 2)+20.22 \%=\quad \delta^{13} \mathrm{C}$ air $\%_{0}=-7.68$

$$
\text { Mean } \quad \delta^{13} \mathrm{C} \text { air \%o }=-8.15
$$


When the canopy constant (1\%o) is subtracted from the modern tree tissue record, the recalculated record of $\delta^{13} \mathrm{C}$ air $\%$ is -8.48 , closer to the grass and fern whole leaf tissue. The new mean value from all modern plant whole leaf tissue data $\left(-8.15 \%\right.$ ) is now closer to the $2002 \delta^{13} \mathrm{C}$ air \%o mean of $-8.02 \%$ recorded at Baring Head, New Zealand.

To calculate a carbon isotopic atmospheric signal from phytolith-occluded carbon, account needs to be taken of the further fractionation that occurs between plant whole leaf material and phytolith-occluded carbon extracted from the same plant material, e.g. $\delta^{13} \mathrm{C}$ plant $=\delta^{13} \mathrm{C}$ phytolith + phytolith fractionation. This phytolith fractionation is different for grass, fern and tree/shrub and is referred to in the following equations as either a grass phytolith constant (gpc), a tree phytolith constant (tpc) or a fern phytolith constant (fpc) (Section 3.5.2).

Eq.6a: $\delta^{13} \mathrm{C}$ air $\%$ o $\left.=\delta^{13} \mathrm{C}_{\text {grass phytolith }}+20.22\right)+3.0 \%$ (gpc).

Eq. 6b: $\delta^{13} \mathrm{C}$ air $\left.\%=\delta^{13} \mathrm{C}_{\text {tree phytolith }}+21.22\right)-1.22 \%$ (tpc).

Eq. 6c: $\delta^{13} \mathrm{C}$ air $\%=\delta^{13} \mathrm{C}_{\text {fern phytolith }}+20.22+0.4 \%$ (fpc).

NOTE: In equation $6 \mathrm{~b}(\mathrm{tpc})$ is subtracted, rather than added because the fractionation effect between whole tree plant material and tree phytolith occluded carbon is positive (refer Figs. 3.3 and 3.4).

Grass phytolith carbon mean $=-31.50(n 9)+23.22 \%=\delta^{13} \mathrm{C}$ air $\%$ o $=-8.28$

Tree phytolith carbon mean $=-28.47(n 22)+20.00 \%=\delta^{13} \mathrm{C}$ air $\%=-8.47$

Fern phytolith carbon mean $=-28.26(n 2)+20.62 \%=\delta^{13} \mathrm{C}$ air $\%=-7.66$

$$
\text { Mean } \delta^{13} \mathrm{C} \text { air \%o }=-8.14
$$

This value is in close agreement with the $2002 \delta^{13} \mathrm{C}$ air \%o mean of -8.02 recorded at Baring Head, New Zealand (Keeling et al. 2005). These results give confidence in this method, as a way of calculating an atmospheric $\delta^{13} \mathrm{CO}_{2}$ signal from phytolith-occluded carbon. Moreover, the method should be equally applicable in reconstructing long ancient atmospheric $\delta^{13} \mathrm{CO}_{2}$ records. 


\subsection{Conclusion}

This chapter gives a first documentation and description of $\delta^{13} \mathrm{C}$ values of phytoliths extracted from a number of New Zealand native plants, three species of grass, two species of tree fern, and ten species of tree. The first carbon isotope values from the analysis of the leaves from the same species are presented. It also provides the first evidence of the presence of measurable carbon sealed within phytoliths extracted from the leaves from New Zealand plants. Results are also presented from the carbon isotope analysis of these phytolith occlusions. This study raises two unsolved questions; first, what causes the differences in carbon isotopic values between grasses and trees? and second, what causes the possible seasonal differences in carbon isotopic values? The answer to both these questions is probably related to differences in carbon compounds present within phytolithoccluded carbon and differences in concentrations between the same compounds. The pilot NMR study appears promising in resolving both these questions. Finally, in positively answering the original hypothesis, values and arguments are presented which demonstrate that it is possible to derive a measure of the atmospheric $\delta^{13} \mathrm{CO}_{2}$ used by the plant from the time the plant was absorbing atmospheric carbon dioxide during photosynthesis, from phytolith occluded carbon. 


\section{Chapter 4:}

\section{Atmospheric $\delta^{13} \mathrm{CO}_{2}$ Signal from Ancient Phytolith-occluded Carbon}

\subsection{Introduction}

One of the major questions facing paleoclimate modellers deals with how carbon cycled between the three major carbon reservoirs, the ocean, atmosphere and biosphere during the last glacial period. We know from analysis of air trapped within Antarctic ice, that atmospheric $\mathrm{CO}_{2}$ concentrations changed by increasing and decreasing during that period, with concentrations varying between 180 to $280 \mathrm{ppm}$ (Petit and al., 1999; Sigman and Boyle, 2000). Not yet known are the rates and processes by which carbon is exchanged between the ocean, atmosphere and biosphere.

In attempting to resolve this problem, a number of methods such as marine and terrestrial carbon isotopes, computer based reconstructions, and paleoenvironmental reconstructions and a combination of all or some of these methods have been considered. Shackleton (1977) was the first to suggest that changes in the marine $\delta^{13} \mathrm{C}$ record $\left(\Delta \delta^{13} \mathrm{C}\right)$ could be used to infer changes in the storage of terrestrial carbon. His first estimate of $\sim 0.7 \%\left(\Delta \delta^{13} \mathrm{C}\right)$, a shift from glacial to interglacial marine changes in average marine carbon, has since been updated by the more recent and extensive studies of Curry et al., (1988) and Duplessy et al., (1988). A re-evaluation of their data by Crowley (1995) has given the best marine-based estimate thus far of transfer of carbon from the land to the ocean. This is $0.40 \% \Delta \Delta \delta^{13} \mathrm{C}$, which equates to an increase in 610 Gigatonnes of carbon (Gt C) during the last glacial period. Combinations of palynological, pedological and sedimentological data have been used to reconstruct biome distributions as a measure of on-land carbon sequestration (Adams et al., 1990; Adams et al., 1999.; Crowley, 1991; Crowley, 1995; Peng et al., 1998; Van Campo et al., 1993). These estimates range between $\sim 430$ to $\sim 1900 \mathrm{Gt} \mathrm{C}$, giving an average of $\sim 1000 \mathrm{Gt} \mathrm{C}$. Others have used computer models in an attempt to measure changes to the carbon cycle during the last glacial cycle. These have given results of between -30 to $+1106 \mathrm{Gt} \mathrm{C}$, with an average of $\sim 570 \mathrm{Gt} C$ (Prentice and Fung 1990; 
Friedlingstein et al. 1995; Beerling 1999; Francois et al. 1997; Otto et al. 2002; Kaplan et al. 2002). However, there still exists a considerable range in estimates from these different methods (Table 4.1).

Table 4.1: Estimates and averages of changes in carbon stored in terrestrial biosphere since the LGM using marine carbon isotope budgeting, paleoecological data and computer modelling (modified from Maslin and Thomas 2003)

\begin{tabular}{|c|c|c|}
\hline Author & Basis & $\begin{array}{l}\text { Holocene to LGM change } \\
\text { in GtC }\end{array}$ \\
\hline \multicolumn{3}{|c|}{ From carbon in marine sediments } \\
\hline Crowley 1995 & Marine $\delta^{13} C$ & 610 \\
\hline Crowley 1991 & Marine $\delta^{13} \mathrm{C}$ & 450 \\
\hline Maslin et al. 1995 & Marine $\delta^{13} C$ & $400-1100(700)$ \\
\hline AVERAGE & & 600 \\
\hline Adams et al. 1990 & Paleoecological data & 1350 \\
\hline Adams et al 1998 & Paleoecological data & $900-1900(1500)$ \\
\hline Crowley 1995 & Terrestrial Vegetation data & $750-1050(900)$ \\
\hline Peng et al. 1998 & Paleoecological data & $470-1014(750)$ \\
\hline Van Campo et al. 1993 & Paleoecological data & $430-930(715)$ \\
\hline AVERAGE & & 1000 \\
\hline \multicolumn{3}{|c|}{ From computer models } \\
\hline Prentice and Fung 1990 & Climate model & $-30-+50(10)$ \\
\hline $\begin{array}{l}\text { Friedlingstein et al. } \\
1995\end{array}$ & Climate (biosphere) model & $507-717(612)$ \\
\hline Beerling 1999 & Biosphere model $\left(\delta^{13} \mathrm{C}\right)$ & $550-680(615)$ \\
\hline Francois et al. 1997 & Biosphere model & $134-606(370)$ \\
\hline Otto et al. 2002 & $\begin{array}{l}\text { Dynamic Global } \\
\text { Circulation model }\end{array}$ & $828-1106(970)$ \\
\hline Kaplan et al. 2002 & $\begin{array}{l}\text { Dynamic Global } \\
\text { Circulation model }\end{array}$ & 821 \\
\hline AVERAGE & & 570 \\
\hline
\end{tabular}

Another possible approach is to directly measure $\delta^{13} \mathrm{C}$ in air bubbles in ice and relate changes in concentration to the movement of carbon between the three major reservoirs. Unfortunately, despite good records of volumes of $\mathrm{CO}_{2}, \mathrm{CH}_{4}$, $\mathrm{N}_{2} \mathrm{O}$, and ${ }^{18} \mathrm{O}$ from long ice cores (e.g. Bender et al. 1994, Blunter et al. 1998, Petit et al. 1999, Etheridge et al. 1998, Munning et al. 2004), there are only scattered $\delta^{13} \mathrm{C}$ records of atmospheric $\mathrm{CO}_{2}$ (Leuenberger et al. 1992, Smith et al. 1999, Eyre 2003). The problem in obtaining good $\delta^{13} \mathrm{C}$ records from Northern Hemisphere ice cores is related to the presence of carbonate dust particles. The break down of these particles 
can release $\mathrm{CO}_{2}$, thereby contaminating the results. As there are little or no carbonate particles in the Southern Hemisphere ice cores, these should be a better prospect. Unfortunately, additional problems have been recognised associated with the solubility of $\mathrm{CO}_{2}$ in water during analysis. When the ice is crushed to release the trapped gas, thin films of water form on the ice. These films affect the small amount of $\mathrm{CO}_{2}$ that comes from the bubbles and as a result there is a large statistical error (Eric Steig University of Washington, Seattle pers com).

Schleser (1995) suggested that unaltered plant matter could provide an ideal archive of environmental and climatic information for climate reconstruction. A number of studies have measured the $\delta^{13} \mathrm{C}$ of plant material and used these records as proxy for atmospheric $\delta^{13} \mathrm{CO}_{2}$. In principle, measurements of atmospheric $\delta^{13} \mathrm{CO}_{2}$ can be used to distinguish the relative importance of oceanic and terrestrial biospheric exchange as mechanisms for removal of $\mathrm{CO}_{2}$ from the atmosphere (Marino and McElroy 1991). Therefore, it follows that because plants photosynthesise carbon material from atmospheric $\mathrm{CO}_{2}$, the carbon isotopic ratios in plant material should be a reflection of atmospheric $\delta^{13} \mathrm{CO}_{2}$ from the time the plant was growing. A number of studies have attempted to obtain records of variations in atmospheric $\mathrm{CO}_{2}$ by measuring the carbon isotopes in tree rings (Leavitt and Long 1983, 1989; Stuvier et al. 1984; Krishnamurthy and Epstein 1990; Epstein and Krishnamurthy 1990). Unfortunately, because of physiological factors, the results have proved ambiguous, with large variations (up to $4 \%$ ) in $\delta^{13} \mathrm{C}$.

Marino and McElroy (1991) developed a method of obtaining an atmospheric $\delta^{13} \mathrm{CO}_{2}$ signal from $\mathrm{C} 4$ plant material. They demonstrated a constant relationship between the $\delta^{13} \mathrm{C}$ of Zea mays and atmospheric $\delta^{13} \mathrm{C}$, which had excellent agreement with data from ice cores and modern air. Using the same principles Marino et al. (1992) were able to extract an atmospheric $\delta^{13} \mathrm{CO}_{2}$ signal from $\mathrm{C} 4$ shrub Atriplex confertifolia samples recovered from packrat middens for the last $30 \mathrm{ka}$. However, there appears to be a conflict in results from $\delta^{13} \mathrm{C}$ analysis of plant material recovered from packrat middens. The Marino et al. (1992) study estimated that 30,000 years ago atmospheric $\delta^{13} \mathrm{C}$ values were $\sim-7.0 \%$, and dropped to a low of $-7.6 \%$ in the LGM (20,000 yr BP) before rising to a Holocene maximum of $-6.1 \%$ in. In contrast, 
Van de Water et al. (1994) analysed C3 Pinus flexilus needles from 41 packrat middens dating back to $28,020 \mathrm{yr} \mathrm{BP}$. Their results showed that $\delta^{13} \mathrm{C}$ values were higher between 20,000 and 15,000 ka BP than the Holocene. As well as these problems, the technique is limited to being used on one species at a time. Moreover, it has proved difficult to find long time series of single species preserved and protected from alteration in sedimentary deposits.

A new method of deriving an ancient atmospheric $\delta^{13} \mathrm{CO}_{2}$ record using phytolith-occluded carbon as a proxy is described below. When phytoliths form within a plant, some of the host organic matter is trapped inside the phytolith, a process described more fully in Chapter 3. Moreover, because they survive well in most soils and sediments, the trapped carbon remains intact and preserved from contamination and alteration. Furthermore, phytolith-occluded carbon fulfils the criteria set out by Arens et al. (2000) for a suitable medium from which to extract an atmospheric $\delta^{13} \mathrm{CO}_{2}$ signal. 1) That they are identifiable and are able to be isolated from their substrate; 2) that they are uniquely derived from terrestrial vegetation; 3 ) that they contain measurable organic carbon; 4) and that carbon is protected from contamination and alteration.

$\delta^{13} \mathrm{C}$ was measured on carbon from phytoliths extracted from loess samples, and a 125,000 year global atmospheric $\delta^{13} \mathrm{C}$ record was determined from a loess core drilled at Otaraia, on the lower north slope of the Aorangi Range in the lower Wairarapa Valley (Fig. 2.2). The phytoliths were extracted using the same method as described in Chapter 2, with some modifications. Because of the low concentration of occluded carbon it was found that about $80 \mathrm{gm}$ of sediment was needed to produce enough phytoliths for $\delta{ }^{13} \mathrm{C}$ analysis. Also to remove carbon material that may adhere to the exterior of the phytoliths following extraction, phytoliths were washed in a 5\% solution of $\mathrm{KOH}$ (potassium hydroxide) for 15 minutes. These were then centrifuged at $5000 \mathrm{rpm}$ for 5 minutes, the supernatant poured off and the process repeated three times. The recovered phytoliths were then dried at $40^{\circ} \mathrm{C}$. The centrifuge tube was uncapped and covered in a way to permit evaporation without dust contamination. When dry, the sample was sealed and weighed. Then the carbon isotopes of the phytolith-occluded were measured on the 
Institute of Geological and Nuclear Sciences Europa Geo 20/20 isotope mass spectrometer using the same method as described in Chapter 3.

\subsection{Results and Initial Assessment}

The $\delta{ }^{13} \mathrm{C}$ analysis results for the carbon in phytoliths from core samples from the Otaraia core are shown in Fig. 4.1 (values listed in table 4.2 and Appendix 3). A first view of the record shows recognisable trends through the core beginning with a low value $(-32 \%$ ) at the base at $7.4 \mathrm{~m}$, rising to $-30.5 \%$ at $6.3 \mathrm{~m}$, and then after a brief drop to $-32.5 \%$ rising steadily to $-26.0 \%$ at $5.0 \mathrm{~m}$. The curve then oscillates between $-26.0 \%$ and $-29.0 \%$ up to $4.2 \mathrm{~m}$, after which it drops to between -33.0 and $34.0 \%$ (its lowest value), until around $3.3 \mathrm{~m}$, when it rises rapidly to $-28.0 \%$ at 2.6 $\mathrm{m}$. At $2.4 \mathrm{~m}$ it drops to $-32.0 \%$, but quickly returns to $-30.0 \%$, until at $1.6 \mathrm{~m}$ it almost drops to $-33 \%$ and then to almost $34 \%$ before rising to between $-30 \%$ and $28 \%$ from $1.6 \mathrm{~m}$ to the top of the core.

The curve ranges between $-26 \%$ and $-34 \%$, and consists of a mixture of trends interrupted by sharp peaks (both less and more negative), with a notable broad negative peak extending from 3.4 to $4 \mathrm{~m}$. While a couple of the peaks are defined by single points, the main features of the curve are defined by several points showing incremental change, a feature that indicates the values reflect a signal from the time of plant growth when the carbon was fixed. This supports the claim, made in Chapter 1, that phytoliths do capture and seal carbon effectively from diagenetic processes. 


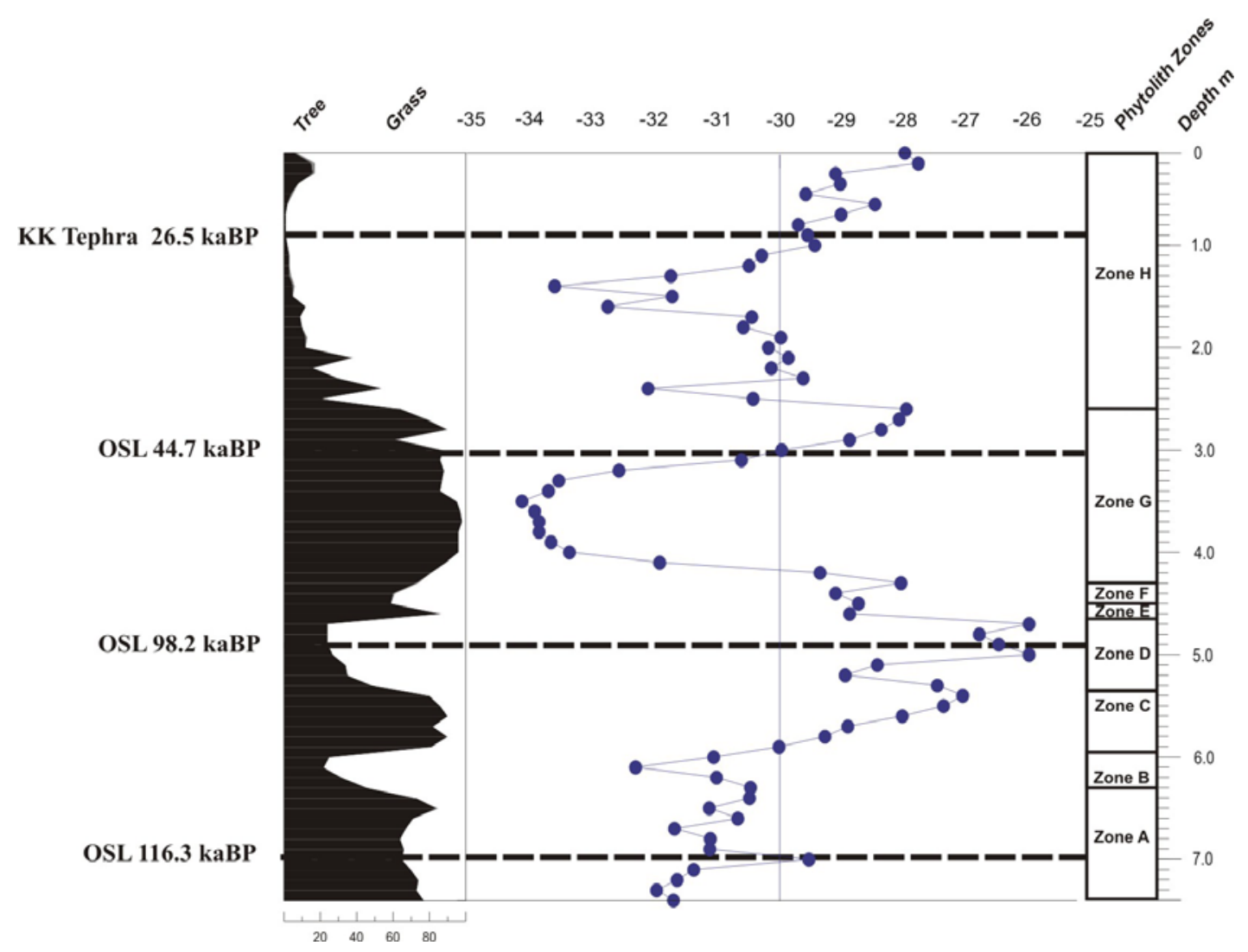

Fig. 4.1: Diagram of Otaraia core $\delta{ }^{13} \mathrm{C}$ values of phytolith-occluded carbon plotted against depth. Left-hand column tree (black) \& grass (white) phytolith percentages; and right-hand column shows phytolith zones. 
Table 4.2: Otaraia phytolith $\delta^{13} \mathrm{C}$ values and depths.

\begin{tabular}{|c|c|c|c|c|c|}
\hline Depth (m) & Phytolith $\delta 13 \mathrm{C} \%$ & $\underline{\text { Depth (m) }}$ & Phytolith $\delta 13 C \%$ o & Depth (m) & Phytolith $\delta 13 \mathrm{C} \%$ \\
\hline 0.1 & -27.98 & 2.6 & -27.95 & 5.1 & -28.42 \\
\hline 0.2 & -26.76 & 2.7 & -28.07 & 5.2 & -28.94 \\
\hline 0.3 & -29.10 & 2.8 & -28.36 & 5.3 & -27.45 \\
\hline 0.4 & -29.02 & 2.9 & -28.87 & 5.4 & -27.04 \\
\hline 0.5 & -29.58 & 3.0 & -29.97 & 5.5 & -27.35 \\
\hline 0.6 & -28.96 & 3.1 & -30.62 & 5.6 & -28.02 \\
\hline 0.7 & -29.01 & 3.2 & -32.60 & 5.7 & -28.90 \\
\hline 0.8 & -29.70 & 3.3 & -33.57 & 5.8 & -29.27 \\
\hline 0.9 & -29.55 & 3.4 & -33.74 & 5.9 & -30.01 \\
\hline 1.0 & -29.43 & 3.5 & -34.17 & 6.0 & -31.07 \\
\hline 1.1 & -30.29 & 3.6 & -33.96 & 6.1 & -32.33 \\
\hline 1.2 & -30.50 & 3.7 & -33.89 & 6.2 & -31.02 \\
\hline 1.3 & -31.76 & 3.8 & -33.89 & 6.3 & -30.47 \\
\hline 1.4 & -33.64 & 3.9 & -33.70 & 6.4 & -30.49 \\
\hline 1.5 & -31.74 & 4.0 & -33.40 & 6.5 & -31.14 \\
\hline 1.6 & -32.78 & 4.1 & -31.94 & 6.6 & -30.68 \\
\hline 1.7 & -30.45 & 4.2 & -29.35 & 6.7 & -31.70 \\
\hline 1.8 & -30.59 & 4.3 & -28.04 & 6.8 & -31.12 \\
\hline 1.9 & -29.98 & 4.4 & -29.10 & 6.9 & -31.13 \\
\hline 2.0 & -30.18 & 4.5 & -28.73 & 7.0 & -29.53 \\
\hline 2.1 & -29.86 & 4.6 & -28.87 & 7.1 & -31.39 \\
\hline 2.2 & -30.14 & 4.7 & -25.97 & 7.2 & -31.66 \\
\hline 2.3 & -29.62 & 4.8 & -26.77 & 7.3 & -31.99 \\
\hline 2.4 & -32.13 & 4.9 & -26.46 & 7.4 & -31.72 \\
\hline 2.5 & -30.43 & 5.0 & -25.97 & & \\
\hline
\end{tabular}

\subsection{Influence of Vegetation Type}

In Chapter 3, comparison of $\delta^{13} \mathrm{C}$ values between plants and phytoliths and between those from grass and trees revealed significant differences in both comparisons. These were incorporated in a formula for translating $\delta^{13} \mathrm{C}$ values from phytolith-occluded carbon into an estimate of the $\delta^{13} \mathrm{C}$ value for the carbon in the atmosphere. In this section, two models were used to assess the extent to which variation in the data from the Otaraia core might be affected by the proportions of tree phytoliths, noting that modern tree phytoliths have a significantly different value from grass phytoliths (-28.3 $\pm 0.1 \%$ and $-31.9 \pm 0.1 \%$ respectively) (Fig 4.2). 


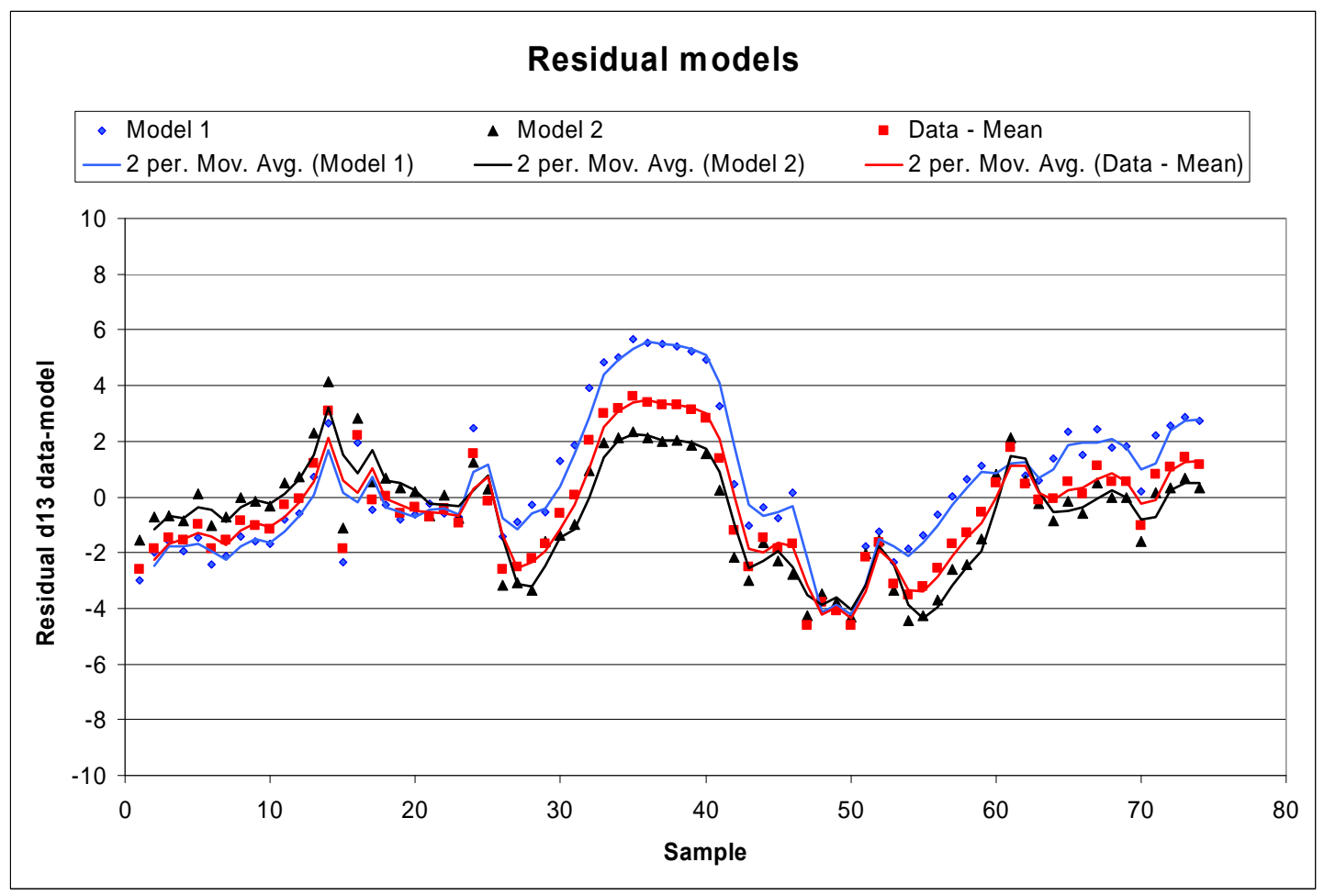

Fig. 4.2: Results from modelling show the possible influence of flora type on $\delta^{13} \mathrm{C}$ values. Red square $=$ Data mean, blue square $=$ model 1 , and black triangle $=$ model 2. (Data in Appendix 1)

If the variation in the $\delta^{13} \mathrm{C}$ data arises in part from variations in flora type (grass, fern, and trees), then models for $\delta^{13} \mathrm{C}$ as a function of the proportions of flora at different times should reduce the variability of the $\delta^{13} \mathrm{C}$ values (reduction of variance). Model 1 attributed all $\delta^{13} \mathrm{C}$ observations to the proportion of each type multiplied by estimate of the mean $\delta^{13} \mathrm{C}$ value for that type, the means being $31.2( \pm$ $0.5), 28.3( \pm 0.2)$, and $28.4( \pm 0.4) \%$ o for grasses, ferns and trees respectively. Thus, if the observed proportions of grass:ferns:trees in a sample were $83: 2: 15$, the predicted $\delta^{13} \mathrm{C}$ value would be:

Eq 7: $\quad(31.2 \times 83)+(28.3 \times 2)+(28.4 \times 15) / 100=30.7 \%$

Model 2 made a more general assumption about the contribution of different flora types to $\delta^{13} \mathrm{C}$, namely that it was of the form:

$\delta^{13} \mathrm{C}=a \mathrm{x}($ proportion grass $)+b \times($ proportion ferns $)+c \times$ (proportion trees) $(\# 2)$ 
where $a, b$ and $c$ were to be determined by least squares. In fact, the small proportions of ferns, and the similarity of the mean fern and tree values meant that $b$ is not practically determinable, and so $b$ was set to zero.

Residuals from the two models were calculated as $\delta^{13} \mathrm{C}$ (observed) $-\delta^{13} \mathrm{C}$ (model). The results are shown in Fig 4.2. Mean squared residuals were compared with the deviations of $\delta^{13} \mathrm{C}$ about its mean, to determine the variance reduction that each model produced. The two models mimic the behaviour of $\left(\delta^{13} \mathrm{C}-\right.$ mean $)$ with time. However, the residuals for models 1 and 2 were 21.6 and 17.3\%o respectively, compared to $17.7 \%$ for the raw data (minus the mean) (Fig. 4.2). It follows that the departures of that curve from zero, which are generally sustained for some time (e.g. samples $\mathrm{O} 35$ to $\mathrm{O} 45)$, is due to an influence other than flora type.

\subsection{Ancient Atmospheric $\delta^{13} \mathrm{CO}_{2}$ Signal}

The analysis above showed that the contribution of vegetation type to the signal was relatively small. Nevertheless, it was judged worthwhile to take this effect into account in applying equations 6 a-c for estimating $\delta^{13} \mathrm{C}$ values for ancient atmospheric carbon (Appendix 4). This was a term added to incorporate the differing fraction effect of each plant group as they absorb atmospheric $\mathrm{CO}_{2}$ into plant material. This yielded equation 8 below:

(Eq. 8): $\delta^{13} \mathrm{CO}_{2 \text { atmos. } \% 0}=\delta^{13} \mathrm{C}_{\text {ancient plant }}+\delta^{13} \mathrm{C}_{\text {fractionation effect }}+\delta^{13} \mathrm{C}_{\text {Gröcke's constant }}+\delta^{13} \mathrm{C}_{\text {canopy constant }}$

In equation 8

$\delta^{13} \mathrm{CO}_{2}$ atmos. is the calculated $\delta^{13} \mathrm{CO}_{2}$ value of the atmosphere

$\delta^{13} \mathbf{C}_{\text {ancient plant }}$ is the measured value of the $\delta^{13} \mathrm{C}$ of the phytoliths extracted from the loess sample.

$\delta^{13} \mathbf{C}$ fractionation effect is the fractionation effect between the whole plant $\delta^{13} \mathrm{C}$ and the phytolith-occluded carbon from each of the three components (grass, fern and tree/shrub) in proportion to their abundance in the sample. (See Fig. 
4.3 for details). Note that the fractionation for grasses and ferns is negative but for tree and shrubs is positive (Fig 3.5).

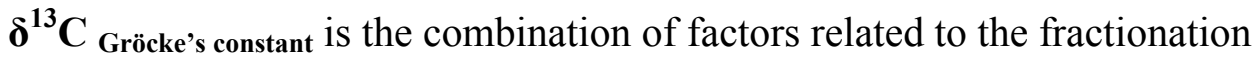
that occurs when plants incorporate atmospheric $\mathrm{CO}_{2}$ (explanation in Chapter $3)$.

$\delta^{13} \mathbf{C}$ canopy constant is the effect that forest canopy affects the $\delta^{13} \mathrm{C}$ recorded in tree material (explanation in Chapter 3).

As with the equations used to extract an atmospheric $\delta^{13} \mathrm{CO}_{2}$ signal from modern phytolith-occluded carbon (Eq. 6 a-c), a canopy constant (c/c) is added to the equation. However, the canopy constant applied to the phytolith-occluded carbon values from ancient sediments is different to that applied to phytolith carbon from modern plant material (Chapter 3). Because the tree density of ancient forests is unknown, this study uses a canopy constant of 0.021 . This is based on the Turney et al. (2002) study which determined that the difference in $\delta^{13} \mathrm{C}$ between sunlit and shaded leaves of Nothofagus solandri var cliffortiodes leaves was 3\%. Using the leaf mass per unit area of leaves landing on the forest floor, they calculated that about $30 \%$ of the leaves were from the sunlit part of the canopy, the remainder from within the canopy. Therefore, if we assume that the tree phytoliths are derived from leaves of similar distribution, i.e. that $30 \%$ of a given tree phytolith assemblage is derived from sunlit canopy leaves and 70\% is derived from within the canopy leaves, we should subtract a canopy constant of $2.1 \%$ ( $70 / 100 \times 3.0 \%$ ) from the tree component of phytolith carbon isotope record. This is calculated on the basis of percentage of tree/shrub in each sample.

As an example, sample O53 carbon had an isotopic value of $-27.5 \%$. The phytolith assemblage is composed of $51 \%$ grass and $49 \%$ tree. Therefore, the phytolith fractionation effects would be $1.5 \%$ from grass $-0.6 \%$ from tree + the Gröcke's constant of $20.2 \%$ o $1.03 \%$ for the tree canopy effect $=22.13 \%$, which is subtracted from $-27.5 \%$ leaving an atmospheric $\delta^{13} \mathrm{C}$ values of $-5.4 \%$. 

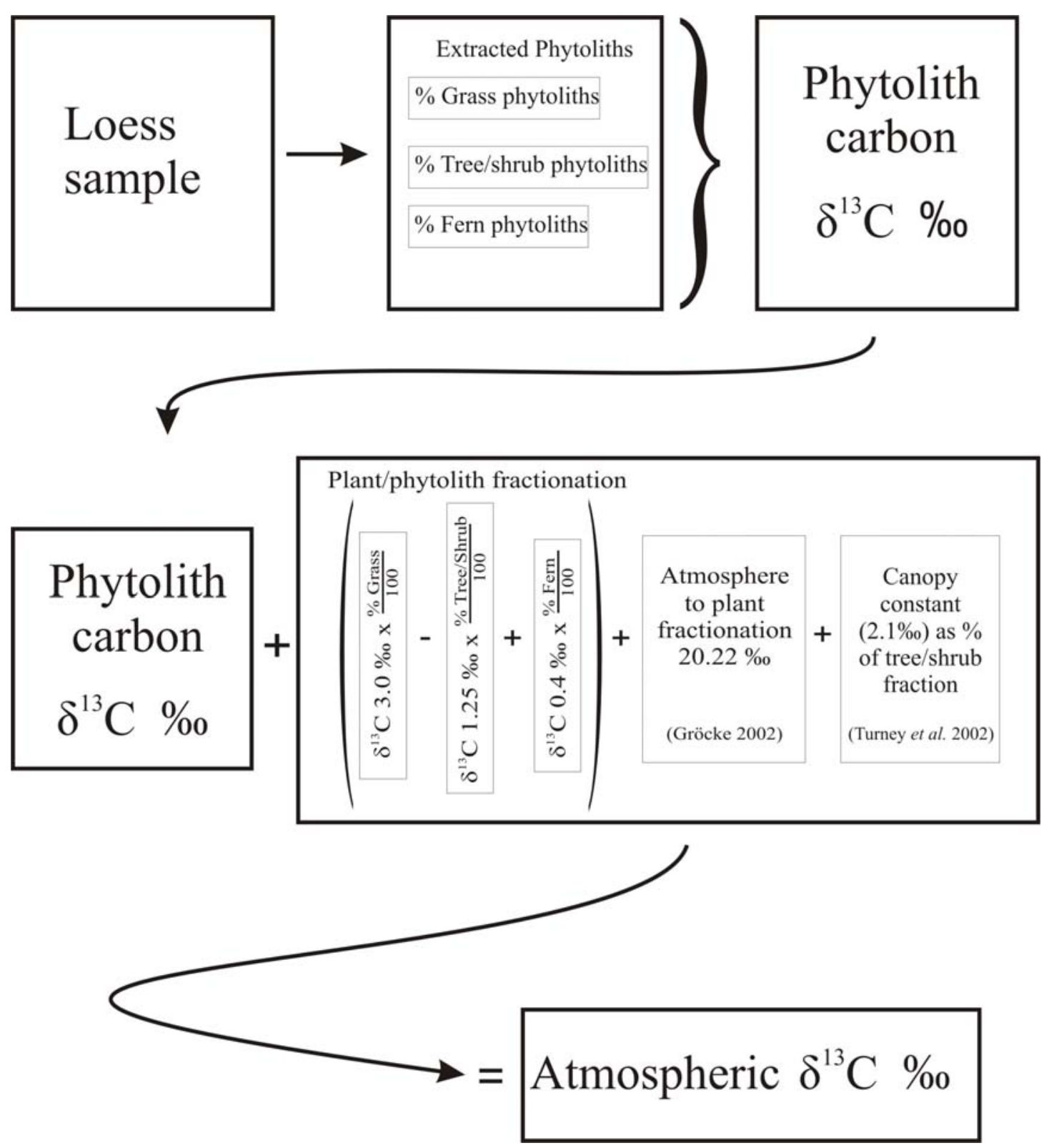

Fig. 4.3: Schematic showing the various stages involved in deriving a $\delta^{13} \mathrm{C}$ signal from ancient phytolith-occluded carbon. 


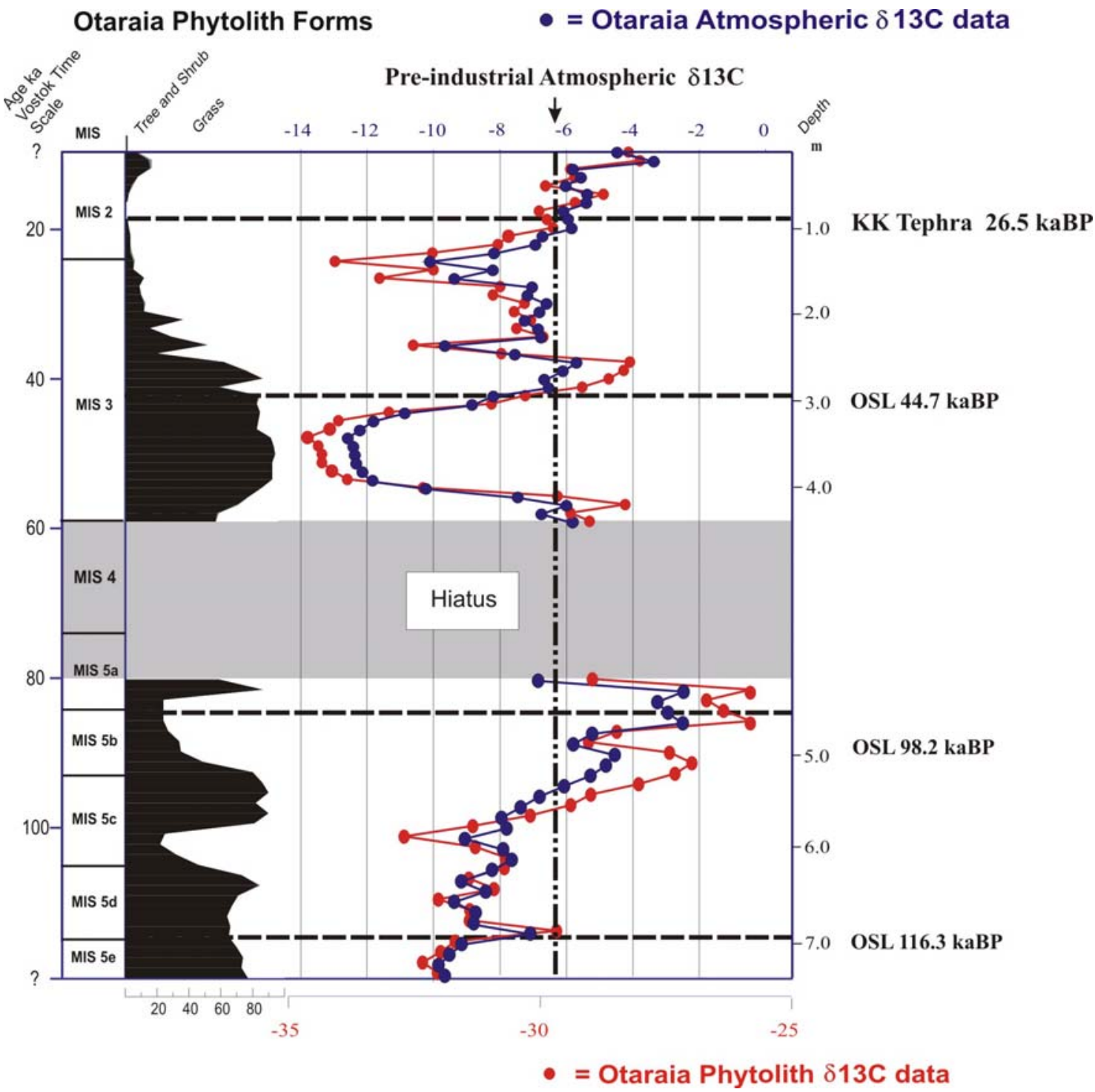

Fig. 4.4: Estimate for atmospheric $\delta^{13} \mathrm{C}$ values over the last 120,000 years in blue (\%). Original Otaraia phytolith-occluded carbon $\delta^{13} \mathrm{C}$ data is shown in red (\%o). Marine Isotope Stages (MIS) (Vostok ages) shown at the left of the diagram. Tephra and OSL ages are shown by dashed lines. Tree phytolith percentages down core are shown in black. Hiatus shown as grey band as developed in Chapter 2. The preindustrial atmospheric $\delta^{13} \mathrm{C}$ value is shown by vertical dashed line.

The derived atmospheric $\delta^{13} \mathrm{C}$ signal closely follows the trends of the Otaraia signal, although the offsets vary in a regular way throughout the whole curve (Fig. 4.4). The derived atmospheric $\delta^{13} \mathrm{C}$ record has a range between $-3.8 \%$ and $-13.0 \%$. The average is $-8.1 \%$, which is close to the modern atmospheric $\delta^{13} \mathrm{C}$ signal of $8.0 \%$ and less than the pre-industrial atmospheric $\delta^{13} \mathrm{C}$, was $-6.4 \%$ (Trudinger et al. 1999). The Otaraia $\delta^{13} \mathrm{C}$ record shows that for most of the last glacial cycle ( $\sim 120,000$ years) the atmosphere had less ${ }^{13} \mathrm{C}$ than either the pre-industrial or the modern atmosphere, suggesting that during these intervals there were major changes 
in the carbon cycle.

Because of the large range in $\delta^{13} \mathrm{CO}_{2}$ values, it was decided to try and narrow the record's range. One of the factors used in Eq. 8 was a pi/pa ratio which is the ratio of internal to atmospheric $\mathrm{CO}_{2}$ of 0.7 . This factor was fixed and the equation was applied to all the samples. This assumes that all the plants were growing under average/ideal growing conditions throughout the whole period. Individual pi/pa ratios were then calculated for each sample, based on changing conditions. The pi/pa ratio will change depending on the environmental conditions in which the plant is living. Some plants growing under arid conditions will shift the pi/pa ratio down to 0.5 , and alternatively, growing under very moist conditions will shift the pi/pa ratio up to 0.8. By assuming that the different percentages of grass, tree/shrub and fern phytoliths in each sample are a reflection of the environmental conditions at the time, an aridity index (I) was developed. The aridity index is based on the type of vegetation in each sample. For example, 0 would equal $0 \%$ tree, suggesting a hyperarid environment, whereas 100 would equal 100\% tree suggesting a hyper-moist environment. The aridity factor was then used to derive a new pi/pa ratio for each sample based on the different percentages of grass, tree/shrub and fern.

Four samples were chosen, based on their different mixtures of grass, tree/shrub and fern phytoliths and $\delta^{13} \mathrm{CO}_{2}$ values recalculated using the recalculated pi/pa ratios.

$\begin{array}{lll}\text { Sample } & \text { Previous } & \text { New } \\ \text { O53 } & -5.28 \% \text { o } & 6.41 \% \text {. } \\ \text { O35 } & -12.99 \% \text { o } & 10.96 \% \text {. } \\ \text { O24 } & -10.07 \% \text { o } & -10.98 \% \text {. } \\ \text { O14 } & -10.52 \% \text { o } & -14.58 \% \text {. }\end{array}$

Unfortunately, the method decreases some values, but amplifies others. It appears that the actual relationship between vegetation and aridity is non-linear, and the aridity index above is too simplistic. However, while the method may be improved to give a regular and consistent reduction in the $\delta^{13} \mathrm{CO}_{2}$ range, it is beyond the scope of this thesis. 


\subsection{Comparison between Otaraia and Byrd Ice-Core $\delta^{13} \mathrm{CO}_{2}$ Data}

There are only a few $\delta^{13} \mathrm{CO}_{2}$ records from the last glacial period (Leuenberger et al. (1992), Smith et al. 1999, Eyer 2003). These records show that between the LGM and the Holocene $\delta^{13} \mathrm{CO}_{2}$ values increased by about $1.2 \pm 0.1 \%$. The ice-core data of Smith et al. (1999) show a 0.5\% drop in ${ }^{13} \mathrm{CO}_{2}$ between 18.0 and $16.5 \mathrm{ka}$, followed by a subsequent increase of $0.7 \%$ from $-7.0 \%$ to $-6.3 \%$ o between 16.5 and $9.1 \mathrm{ka}$. Data from $\delta^{13} \mathrm{CO}_{2}$ analysis of the Byrd ice-core (Leuenberger et al. 1992) shows a variation of $1.6 \%$, but a shift of only about $0.5 \%$ between 40-20 ka and the last 10 (Fig 4. 5). Eyer (2003) analysed samples from the EPICA Dome $\mathrm{C}$ ice core for $\delta^{13} \mathrm{CO}_{2}$. From the top of the core down to about $18 \mathrm{ka}$ the $\delta^{13} \mathrm{CO}_{2}$ values vary between $-7.1 \%$ and $6.1 \%$. Data are missing between $18 \mathrm{ka}$ and $25 \mathrm{ka}$. Between $25 \mathrm{ka}$ and $40 \mathrm{ka}$ the data are more widely spread and $\delta^{13} \mathrm{CO}_{2}$ values vary between $-7.4 \%$ and $-5.8 \%$, indicating no shifts in $\delta^{13} \mathrm{CO}_{2}$.

Because of the problems associated the reliability of the analytical methods and with time control of the above studies, the ice-core results must remain speculative (Kohler et al. 2006, Leuenberger et al.2003 and Eric Steig, University of Washington Oregon pers com). A new improved method for extracting $\delta^{13} \mathrm{CO}_{2}$ data from very small air samples was devised by Ferretti et al. (2000) and used by Leuenberger et al. (2003). Using this method they were able to determine $\delta^{13} \mathrm{C}$ on air samples as small as $0.5 \mathrm{~cm}^{3}$ which corresponds to less than $10 \mathrm{~g}$ of ice. However, since that time no new paleo $\delta^{13} \mathrm{CO}_{2}$ records have been published, leaving this author with no better $\delta^{13} \mathrm{CO}_{2}$ records with which to compare the Otaraia record. 


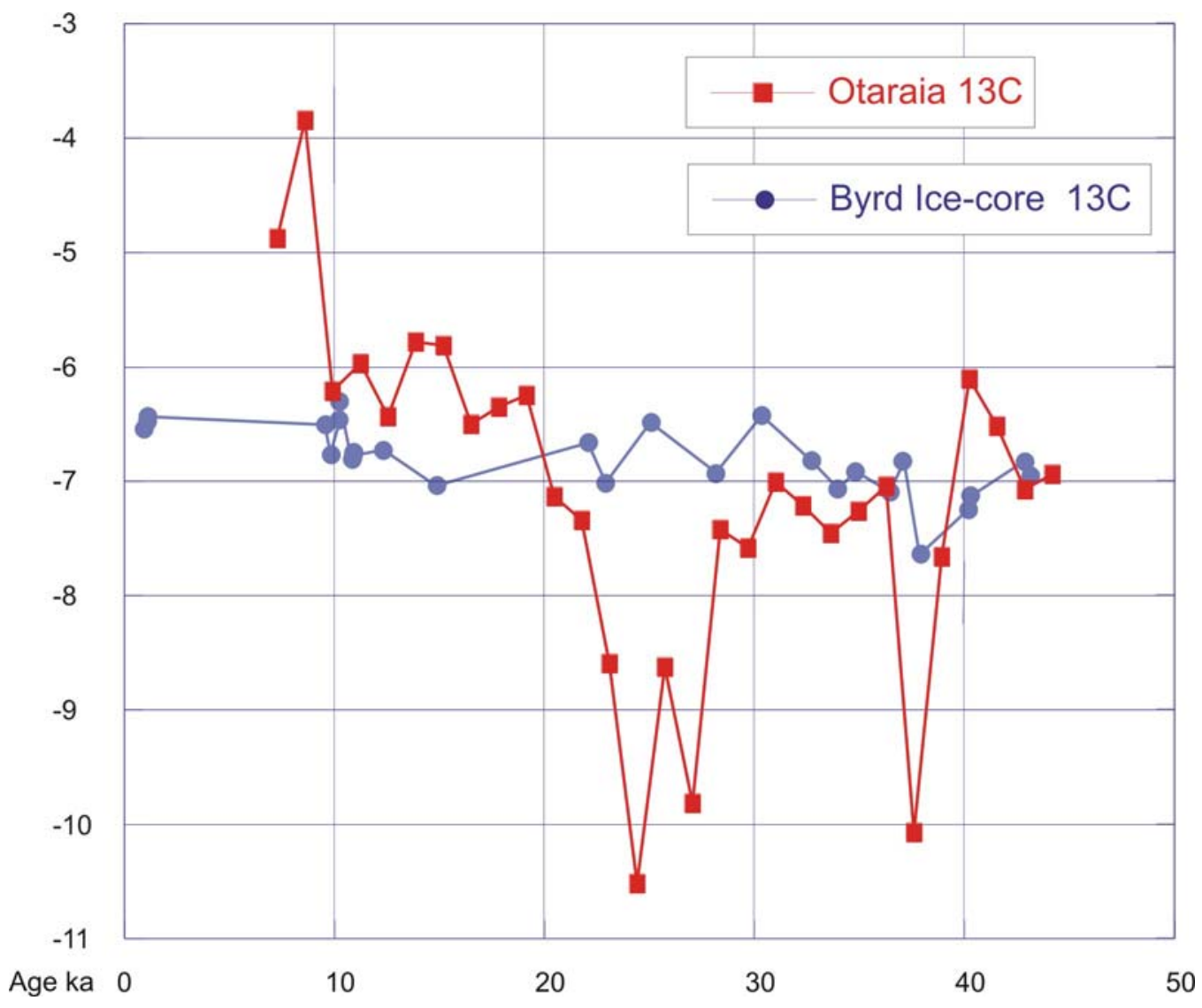

Fig. 4.5: Correlation diagram of Byrd ice-core $\delta^{13} \mathrm{CO}_{2}$ values of Leuenberger et al. (1992) in blue and Otaraia $\delta^{13} \mathrm{CO}_{2}$ values (this study) in red.

The Byrd ice core data of Leuenberger et al. (1992) are plotted against data from this study, for approximately the same period, to show the differences in scale between the two records (Fig 4.5). There are some similarities and differences between the two records. There is agreement in the overall trends between about 10 and $20 \mathrm{ka}$, and 30 and $42 \mathrm{ka}$. There is however, little agreement in the trends between 20 and $30 \mathrm{ka}$, with $\delta^{13} \mathrm{CO}_{2}$ values being more variable in the Otaraia record than in the ice core record.

These differences remain unexplained at present. The rest of this chapter will present and interpret the results of the Otaraia analysis following the logic developed in previous chapters, that indicate that they are estimates of past atmospheric $\delta^{13} \mathrm{CO}_{2}$ values. However, I consider possible error in making these estimates. 


\subsection{1: Errors}

The error in each term in Eq. 8 for the derived atmospheric $\delta^{13} \mathrm{CO}_{2}$ values will contribute to the overall error. The analytical error associated with measuring of phytolith-occluded carbon is $0.1 \%$ (Section 3.4.2). However, greater uncertainties are likely to lie in the fractionation effect, the canopy constant and the Grocke constant. As Table 4.3 shows the former two factors in equation 8 have an effect of around $1 \%$, and hence any error in their determination is unlikely to contribute in a significant way to the derived atmospheric $\delta^{13} \mathrm{CO}_{2}$ value. On the other hand the Grocke constant has a much larger effect, and this is reviewed below.

The "Grocke constant" have been developed directly from the Farquhar (1989) classic model for carbon isotopic fractionation in C3 plants. Farquhar states that the diffusion of air (4.4\%o) and carboxylation (27.0\%) are well established. The diffusion value of $4.4 \%$ may change very slightly with humidity and stomatal behaviour, but carboxylation is considered fixed. The pi/pa ratio is assumed in the Grocke formula to be 0.7 and was chosen because it is a reasonable value for "a plant under average/ideal growing conditions" (Darren Grocke written comment 2006). This gives a value of $20.22 \%$ for the Grocke constant. However, if plants are growing under extreme water stress, the pi/pa ratio could shift down to 0.5 , which would change the Grocke constant to $-15.7 \%$. Alternatively, if plants are growing under high precipitation conditions the pi/pa ratio could shift up to 0.8 which would change the Grocke constant to $-22.48 \%$. In principle it should be possible to determine a pi/pa ratio for the conditions of the period, and hence calculate the appropriate Grocke constant. This is not easy to determine independently, but the floral record in the Wairarapa gives no indication of climatic extremes. While the uncertainty stemming from the effect of the pi/pa ratio is acknowledged, the Grocke constant of $-20.22 \%$ is used without modification for this study. 
Table 4.3: Average mean and standard deviation values from the Otaraia core for the terms in equation 4 relating the derived atmospheric $\delta^{13} \mathrm{CO}_{2}$ to that of ancient plant carbon, fractionation effects for grass, fern and tree, a canopy effect and Grocke's constant.

\begin{tabular}{|l|c|c|c|c|c|c}
\hline & $\begin{array}{c}\text { Derived } \\
\text { Atmospheric } \\
\text { Value }\end{array}$ & $\begin{array}{c}\text { Ancient } \\
\text { Carbon } \\
\text { Value }\end{array}$ & $\begin{array}{c}\text { Fractionation } \\
\text { Effect }\end{array}$ & $\begin{array}{c}\text { Canopy } \\
\text { Effect }\end{array}$ & $\begin{array}{c}\text { Grocke's } \\
\text { Constant }\end{array}$ & Units \\
\hline Average* & -8 & -30.2 & 0.9 & 1.0 & 20.22 & $\delta^{13} \mathrm{CO}_{2}$ \\
\hline Stdev* $^{*}$ & 2.4 & 2.1 & 1.5 & 0.7 & & \\
\hline
\end{tabular}

*for Otaraia data

\subsection{Processes Affecting Carbon Sources and Sinks}

The magnitude of these isotopic fluctuations presents a conundrum, because they are greater than expected by the movement of carbon between land, atmosphere and ocean during the last glacial cycle. There are a number of processes that affect the ${ }^{12} \mathrm{C} /{ }^{13} \mathrm{C}$ ratio of the atmosphere. For example, when there is more vegetation growing on the surface of the Earth the atmosphere becomes more enriched in ${ }^{13} \mathrm{C}$. This is because photosynthesising plants preferentially absorb more of the isotopically lighter and abundant ${ }^{12} \mathrm{C}$, relative to the heavier isotope ${ }^{13} \mathrm{C}$. Marine, terrestrial and computer modelling show that during the last glacial maximum $\sim 750$ Gt $\mathrm{C}$ was transferred from the land to the ocean during the LGM (section 4.1). However, because the average $\delta^{13} \mathrm{C}$ value of terrestrial vegetation is $\sim-26 \%$, a transfer of this amount of carbon from the land to the ocean would not be enough to depress the atmospheric $\delta^{13} \mathrm{C}$ signal to the levels recorded in this study.

An alternative process, which can alter the carbon isotopic ratio of the atmosphere, is a change in the composition of terrestrial plants. The majority of plants use two different photosynthetic pathways when absorbing $\mathrm{CO}_{2}$ from the atmosphere. Today, about $85 \%$ of plants use a $\mathrm{C} 3$ pathway, giving $\delta^{13} \mathrm{C}$ values of between $-22 \%$ and $-30 \%$, and about $15 \%$ of plants use a $\mathrm{C} 4$ pathway, giving $\delta^{13} \mathrm{C}$ values of between $-10 \%$ and $-14 \%$. This results in a global vegetation average $\delta^{13} \mathrm{C}$ value of about $-23.9 \%$ and a consequential atmospheric $\delta^{13} \mathrm{C}$ value of about $-8 \%$. Therefore, if the ratio of $\mathrm{C} 3$ to $\mathrm{C} 4$ plants were to change, the atmospheric $\delta^{13} \mathrm{C}$ value 
would also change. For example, if the composition of terrestrial plants consisted $50 \% \mathrm{C} 4$ to $50 \% \mathrm{C} 3$ plants, this would affect the atmospheric $\delta^{13} \mathrm{C}$ values, making them less negative, and less $\mathrm{C} 4$ plants would lead to more negative atmospheric $\delta^{13} \mathrm{C}$ values. However, the change in the $\mathrm{C} 3 / \mathrm{C} 4$ balance is expected to be small and hence the change in atmospheric $\delta^{13} \mathrm{C}$ would also be small (Huang et al. 2001, Still et al. 2003).

In contrast, the release of stored methane $\left(\mathrm{CH}_{4}\right)$ to the atmosphere would have a large effect on the atmospheric $\delta^{13} \mathrm{C}$ record (Kennett et al. 2003). The major sources of methane are the northern peat lands, tropical wetlands and marine clathrates (methane hydrates). In general, most clathrates have $\delta^{13} \mathrm{CH}_{4}$ of $-60 \%$ or lower (Whiticar 1993). Measurements from the composition of the air in bubbles trapped in polar ice give the best record of atmospheric methane concentration through a number of glacial cycles, e.g. the Greenland Ice Sheet Project, the Greenland Ice Core Project, and the European Project for Ice Coring in Antarctica (Petit et al. 1999, Brook et al. 2000). Atmospheric methane is destroyed in the troposphere by reaction with the hydroxyl radical $(\mathrm{OH})$ and converted to $\mathrm{CO}_{2}$ and water in about 8 years. It follows that the $\mathrm{CO}_{2}$ added to atmosphere following methane oxidation will lower atmospheric $\delta^{13} \mathrm{CO}_{2}$ by dilution. During the period covered in this study, the concentration of carbon dioxide in the atmosphere fluctuated between $\sim 180$ and $\sim 280$ ppm (parts per million), whereas, that of methane has fluctuated between $\sim 350$ and $\sim 650 \mathrm{ppbv}$ (parts per billion by volume) (Petit et al. 1999) (Fig. 4.6).

Apart from the obvious increases in atmospheric $\mathrm{CH}_{4}$ during the present and previous interglacial periods, the Vostok record shows a number of intervals where atmospheric $\mathrm{CH}_{4}$ concentrations were above 500 ppbv. The cause of these increases is in dispute. One school of thought, "the clathrate gun hypothesis" suggests that these spikes are caused by a massive release of methane hydrates (clathrates) (Nisbet 1990, 2002; Kennett et al. 2000, 2003; Milo et al. 2005, Weitemeyer \& Buffett 2006). Clathrates are solid crystalline compounds of $\mathrm{H}_{2} \mathrm{O}$ and $\mathrm{CH}_{4}$ that occur when water molecules form a cage-like structure around a smaller methane molecule. Clathrates form and remain stable in the ocean and permafrost regions on land, and 
under conditions of low temperatures and high pressures at sea. In continental polar regions, they form below $150 \mathrm{~m}$ on land, where surface temperatures are below $0^{\circ} \mathrm{C}$. In oceanic sediment clathrates occur where bottom waters are $\sim 0^{\circ} \mathrm{C}$ and in water depths between 300 and $2000 \mathrm{~m}$ (Kvenvolden and Lorenson 2001). The size of the global clathrate reservoir is in dispute, with original estimates of around 11,000 (GtC), but recent work has reduced this to between 500-2500 GtC (Milkov 2004). The hypothesis is that an increase in ocean temperature and/or a reduction in pressure could trigger a massive release of methane to the ocean and atmosphere. Nisbet (1990) proposed that the change from glacial to interglacial conditions could be driven by the catastrophic release of clathrates stored beneath permafrost and beneath the seafloor around continental margins. Kennett et al. (2000) demonstrated that negative $\delta^{13} \mathrm{C}$ excursions recorded in the shells of foraminifera were related to the release of clathrates from beneath the sea floor, creating a flux of methane into the water column. Late Quaternary strata drilled in the Santa Barbara Basin off the coast of California recorded four episodes of brief but massive release of $\mathrm{CH}_{4}$ during marine isotope stage 3 . This suggests that the conditions that caused the destabilisation of clathrates and release of methane were the combination of warmer intermediate waters and a sea-level $\sim 80$ m lower than present at the beginning of interstadials (Kennett et al. 2000).

The "clathrate gun hypothesis" is also supported by the research of Milo et al. (2005). They recorded a number of negative $\delta^{13} \mathrm{C}$ anomalies in planktic and benthic foraminifera extracted from a sequence of marine cores from the south-western Greenland Sea. These are interpreted as a result of a number of incursions by the overflow of warmer intermediate water into the Greenland Sea, which destabilised clathrates and released methane. The timing of the negative $\delta^{13} \mathrm{C}$ events correspond with $\mathrm{CH}_{4}$ maxima recorded in ice core data.

An alternative "wet-land methane hypothesis" suggests that peaks in $\mathrm{CH}_{4}$ concentration recorded in ice core data were caused by emissions from tropical wetlands and boreal peat bogs (e.g. Maslin \& Thomas 2003, van Huissteden 2004, MacDonald 2006). It was originally thought that wetland expansion was slow to respond during warming periods and would not contribute much of the methane seen 
in the ice core records (Kennett et al. 2003). However, a model of the deglacial global carbon budget showed that clathrate releases contributed less than $30 \%$ of the increase in atmospheric $\mathrm{CH}_{4}$ (Maslin \& Thomas 2003). They suggested that glacialinterglacial variations in atmospheric $\mathrm{CH}_{4}$ were the result of changes in the extent of tropical and temperate wetlands. It has been demonstrated by van Huissteden (2004) that extensive wetlands existed in a large part of Europe during MIS3. His modelling of wetland ecology during this period showed wetland methane fluxes responding immediately to climate change due to temperature effects and bacterial metabolic rates. Furthermore, a large number of radiocarbon dates demonstrate that circumarctic peat-lands began to develop by $16.5 \mathrm{ka}$, and it has been shown by MacDonald et al. (2006) that these peat-lands expanded rapidly in concert with increasing temperatures and high summer insolation between 12 and $8 \mathrm{ka}$.

\subsection{Comparison between Otaraia $\delta^{13} \mathrm{CO}_{2}$ and $\operatorname{Vostok} \mathrm{CO}_{2}$ and $\mathrm{CH}_{4}$ data}

Figure 4.6 compares the entire atmospheric $\delta^{13} \mathrm{CO}_{2}$ for the last 120,000 years derived from the Otaraia loess core with the ice core record of $\mathrm{CO}_{2}$ and $\mathrm{CH}_{4}$ concentrations from Vostok with the revised chronology of Petit et al. (1999). The comparison is based on the age model for the Otaraia core developed in Chapter 2 , pinned by ${ }^{14} \mathrm{C}$ and OSL ages and recognising a major hiatus from $\sim 58-80 \mathrm{ka}$.

The overall trend in atmospheric $\mathrm{CO}_{2}$ and $\mathrm{CH}_{4}$ levels in the Vostok core is one of decline in abundance from 120 to $20 \mathrm{ka}$ followed by a rapid return to the high levels of $120 \mathrm{ka}$. The Otaraia record, however, shows at least six significant periods when $\delta^{13} \mathrm{CO}_{2}$ reduces rapidly, each lasting a few thousand years and each time returning to the baseline. The six $\delta^{13} \mathrm{CO}_{2}$ episodes in Otaraia core are labelled 1-6 in Fig. 4.6, and summarised in Table 4.3.

The overall trend in the $\delta^{13} \mathrm{CO}_{2}$ curve is one of progressive rise from 120 to $80 \mathrm{ka}$ with falls corresponding to three Vostok methane peaks at $\sim 105,100$ and $85 \mathrm{ka}$ (episodes 1-3). Above the hiatus the $\delta^{13} \mathrm{CO}_{2}$ falls to a low of -13\% (episode 4), corresponding roughly with a $4^{\text {th }}$ broad methane peak from $50-55 \mathrm{ka}$, then rising to levels typical of the last $10-40 \mathrm{ka}$ in the Byrd ice core $(-7 \pm 1 \%)$. Two other negative 
$\delta^{13} \mathrm{CO}_{2}$ peaks (episodes 1 and 2) could roughly correspond to Vostok methane peaks at 40 and $32 \mathrm{ka}$.

Table 4.4: Correlation between low $\delta^{13} \mathrm{CO}_{2}$ episodes at Otaraia and $\mathrm{CH}_{4}$ spikes in Vostok Ice Core.

\begin{tabular}{|c|c|c|c|c|}
\hline Episode & $\begin{array}{c}\text { Otaraia Core } \\
(\mathbf{m})\end{array}$ & Vostok Age (ka) & Otaraia $\mathbf{8}^{\mathbf{1 3}} \mathbf{C O}_{\mathbf{2}}$ & Vostok $\mathbf{C H}_{\mathbf{4}}$ \\
\hline $\mathbf{1}$ & 6.5 & $\sim 105$ & $-9.6 \%$ o & $591 \mathrm{ppbv}$ \\
\hline $\mathbf{2}$ & 5.9 & $\sim 100$ & $-8.5 \%$ o & $521 \mathrm{ppbv}$ \\
\hline $\mathbf{3}$ & 4.6 & $\sim 85$ & $-7.5 \%$ o & $594 \mathrm{ppbv}$ \\
\hline Hiatus & & & & \\
\hline $\mathbf{4}$ & 3.5 & $\sim 55$ & $-12.9 \% \mathrm{p}$ & $528 \mathrm{ppbv}$ \\
\hline $\mathbf{5}$ & 2.4 & $\sim 40$ & $-10.1 \% \mathrm{o}$ & $537 \mathrm{ppbv}$ \\
\hline $\mathbf{6}$ & 1.4 & $\sim 32$ & $-10.5 \% \mathrm{p}$ & $548 \mathrm{ppbv}$ \\
\hline
\end{tabular}




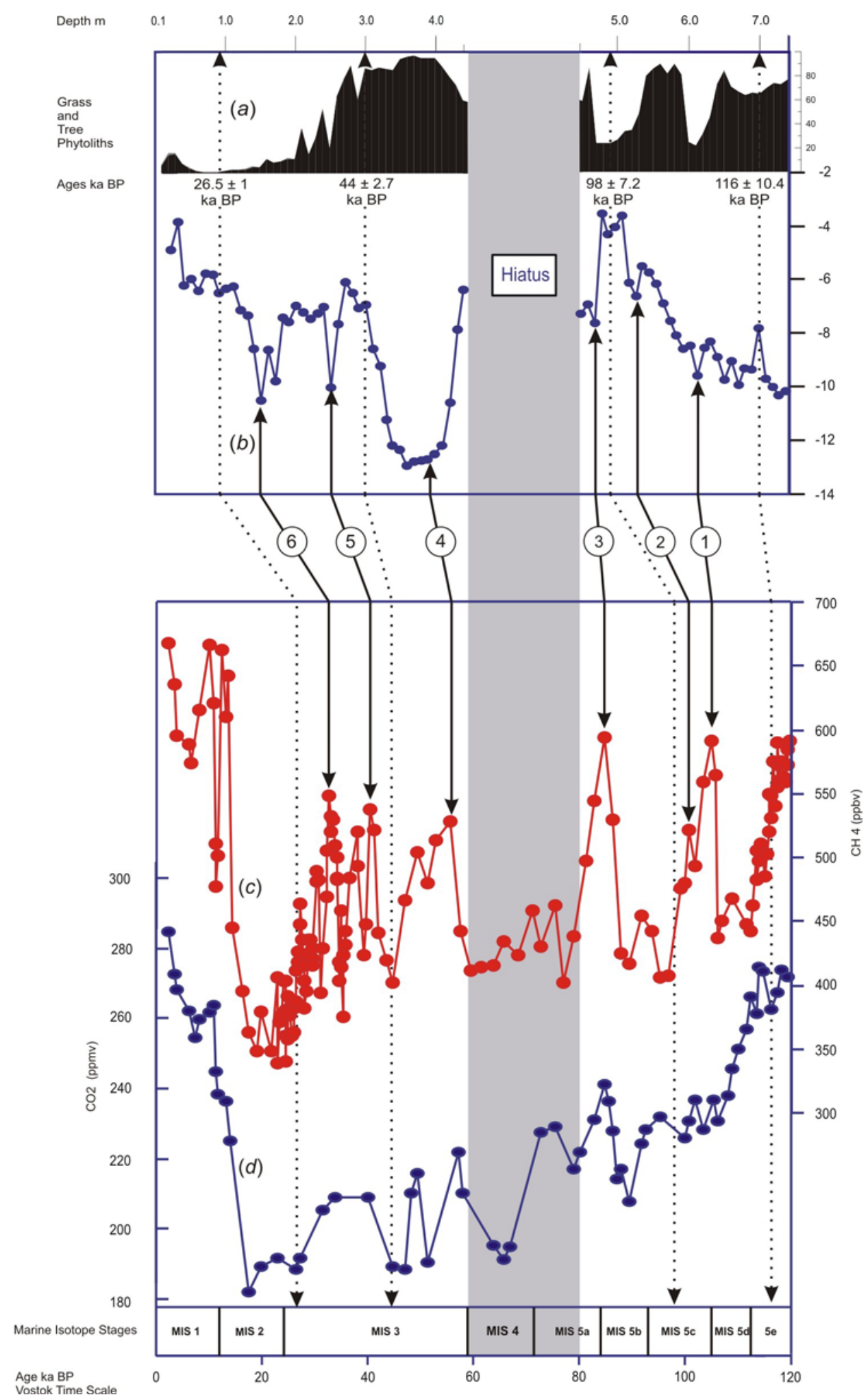

Fig. 4.6: (a) Otaraia phytolith morphological percentages, $(b)$ Otaraia atmospheric $\delta^{13} \mathrm{CO}_{2}$, (c) Vostok atmospheric $\mathrm{CH}_{4}$ concentration (Petit 1999), (d) Vostok atmospheric $\mathrm{CO}_{2}$ concentration (Petit 1999). The gap in the Otaraia record is represented by grey shading. Dotted lines link the ages between the records. Black numbered tie lines linking prominent Otaraia $\delta^{13} \mathrm{CO}_{2}$ deviations with similar deviations in the Vostok $\mathrm{CH}_{4}$ of Petit et al. (1999). 
The six episodes show that there have been a number of occasions when the Otaraia atmospheric $\delta^{13} \mathrm{CO}_{2}$ record shows abnormally low values. These low $\delta^{13} \mathrm{CO}_{2}$ episodes may reflect major rearrangements in the movement of carbon between the atmosphere, biosphere and ocean, and perhaps when large amounts of methane with very low $\delta^{13} \mathrm{CH}_{4}$ values were released into the atmosphere. The oxidation of this anomalously low $\delta^{13} \mathrm{CH}_{4}$ could then have reduced $\delta^{13} \mathrm{C}$ values in $\mathrm{CO}_{2}$, some of which was subsequently absorbed by plants growing at the time, and preserved in phytolithoccluded carbon.

The Holocene $\delta^{13} \mathrm{CO}_{2}$ values from the Otaraia core are difficult to explain, being low in an interglacial world. However the values come from the top $20 \mathrm{~cm}$ of the core, and could well have been influenced by agricultural practices e.g. ploughing and burning, thus making these values suspect.

Episode (1) occurred within a long period characterized by cooling, and large volumes of carbon were being transferred from the land to the ocean, and ice sheet growth caused sea-level to drop (Bradley 1999) The small increase in $\delta^{13} \mathrm{CO}_{2}$ and corresponding large increase in $\mathrm{CH}_{4}$ is interpreted as the result of a marine clathrate release (Kennett et al. 2003). This was probably caused by a pressure reduction, resulting from the lowering of sea-level. The methane would rapidly oxidise to $\mathrm{CO}_{2}$ and because of the low $\delta^{13} \mathrm{C}$ value ( -60\%) it would dilute atmospheric $\delta^{13} \mathrm{CO}_{2}$. However, because of the continual removal of $\mathrm{CO}_{2}$ from the atmosphere to the ocean, the overall effect would slightly reduce the amount of atmospheric $\delta^{13} \mathrm{CO}_{2}$ as shown in this record (Fig 4.6).

Episode (2) occurred within a longer interval, where the trend was of increasing $\delta^{13} \mathrm{CO}_{2}$. The slight decrease in atmospheric $\delta{ }^{13} \mathrm{CO}_{2}$ corresponds to increases in $\mathrm{CO}_{2}, \mathrm{CH}_{4}$ and temperature (Fig 4.6). The decrease in $\delta{ }^{13} \mathrm{CO}_{2}$, possibly happened because of a small release of clathrate methane. However, there is difficulty in chronologically separating the temperature, $\mathrm{CO}_{2}$, and $\mathrm{CH}_{4}$ records. Therefore, it is equally possible that the decrease in $\delta^{13} \mathrm{CO}_{2}$ resulted from an increase in vegetation driven by the warming indicated by the temperature, $\mathrm{CO}_{2}$, and $\mathrm{CH}_{4}$ records, (more vegetation equals higher atmospheric $\delta^{13} \mathrm{CO}_{2}$ values) (Farquhar 1997, Petit et al. 1999). 
Episode (3) occurred immediately following an interval showing a very high value of atmospheric $\delta{ }^{13} \mathrm{CO}_{2}$ (Fig. 4.6). The rapid decrease in atmospheric $\delta{ }^{13} \mathrm{CO}_{2}$ to $-7.5 \%$ corresponds to a rise in temperature, $\mathrm{CO}_{2}$ and $\mathrm{CH}_{4}$ (Petit et al. 1999).

Therefore, because of the size and rapidity of the increase in atmospheric methane, it is suggested that the drop in atmospheric $\delta^{13} \mathrm{CO}_{2}$ resulted from a massive release of ${ }^{13} \mathrm{C}$ depleted methane into the atmosphere. The methane probably originated from either a marine (Kennett et al. 2003) or a permafrost (Nisbet 1990) clathrate release. The destabilisation of marine clathrates could have been driven by a combination of warmer intermediate waters and sea-level lowering, similar to conditions suggested by Kennett et al. (2000). Alternatively, methane could have originated from clathrates from melting permafrost or from clathrates in permafrost released from beneath melting ice sheets (Maslin and Thomas 2003, Weitemeyer and Buffett 2006). However, because of the relatively slow rates of ice sheet melting, such a release would also be expected to happen more slowly than the spike shown in Petit et al. (1999) record.

Episode (4) is the largest and most extensive, and starts immediately above the break in the Otaraia atmospheric $\delta{ }^{13} \mathrm{CO}_{2}$ record at $4.45 \mathrm{~m}$. The rapid, broad and extensive lowering of $\delta^{13} \mathrm{CO}_{2}$ reaches a minimum value of $-12.9 \%$ at $3.5 \mathrm{~m}(\sim 55 \mathrm{ka}$ BP). This corresponds to a similar decline in the organic carbon record of Hatte et al. (2001) which has a $\delta^{13} \mathrm{C}$ value of $-24.7 \%$ o between $49-48 \mathrm{ka}$ BP. Both low $\delta^{13} \mathrm{C}$ values correlate with a rise in temperature, and atmospheric $\mathrm{CO}_{2}$ and $\mathrm{CH}_{4}$ (Petit et al. 1999) that occurred between about 55 and 49 ka BP (Fig. 4.6). The reduction in atmospheric $\delta^{13} \mathrm{CO}_{2}$ during this episode is far greater and more extensive than in any other episode recorded here. This suggests that a massive amount of ${ }^{13} \mathrm{C}$-depleted $\mathrm{CH}_{4}$ was released into the atmosphere over a long period of time. The Vostok $\mathrm{CH}_{4}$ record shows two peaks during this period suggesting that there were possibly two clathrates releases. The first at $\sim 55 \mathrm{ka} \mathrm{BP}$ is preceded by increases in temperature and atmospheric $\mathrm{CO}_{2}$ by about 2,000 years (Petit et al. 1999). The second at $\sim 49 \mathrm{ka}$ $\mathrm{BP}$ is closely correlated with a rise in temperature and atmospheric $\mathrm{CO}_{2}$. One hypothesis is that at the start of this episode, ocean temperatures rose in concert with air temperatures. This could possibly lead a destabilisation of marine clathrates, and release large volumes of deplete $\mathrm{CH}_{4}$ into the atmosphere, creating a positive feedback. The additional warming could add more depleted $\mathrm{CH}_{4}$ into the 
atmosphere, from the destabilisation of more marine and/or permafrost clathrate deposits. de Garidel-Thoron et al. (2004) show evidence of two massive releases from clathrate dissociation in the Papua Gulf. $\delta^{13} \mathrm{C}$ values from shallow, deep and benthic foraminifera imply that huge amounts of ${ }^{13} \mathrm{C}$ depleted methane were released into the atmosphere $\sim 55 \mathrm{ka} \mathrm{BP}$ and $39 \mathrm{ka} \mathrm{BP}$. It has also been shown that clathrate deposits can generate beneath an ice sheet under certain pressure and temperature conditions which are thermodynamically stable (Weitmeyer \& Buffett (2006). They suggest that during deglaciation these deposits would destabilise releasing methane into the atmosphere. Moreover, because these events occurred during the longest, and possibly the warmest and wettest interstadial interval (MIS 3) within the last glacial cycle, it is highly probable that global warming during that period would result in the growth of boreal and tropical wetlands, adding more ${ }^{13} \mathrm{C}$-depleted $\mathrm{CH}_{4}$ to the atmosphere (Brook et al. 2000). Paleoenvironmental data show that during MIS 3 there were extensive wet lands in northern Europe, possibly extending into the North Sea basin (van Huissteden 2004).

Episode (5) was an event when atmospheric $\delta{ }^{13} \mathrm{CO}_{2}$ rapidly declined and then quickly rose, which closely corresponds with a rapid rise and decline in atmospheric methane $\sim 40$ ka BP (Petit 1999) (Fig. 4.6). Again, this episode shows more evidence of a large release of ${ }^{13} \mathrm{C}$ depleted $\mathrm{CH}_{4}$. The swiftness shown in both records is suggestive of a clathrate release as described above. The timing of this event corresponds closely with the clathrate release from the Papua Gulf about $39 \mathrm{ka}$ BP, documented by de Garidel-Thoron et al. (2004). In spite of the difference in age, which may result from dating uncertainty, these two events are probably related. This and/or other calthrate release to the atmosphere caused the decline in $\delta^{13} \mathrm{CO}_{2}$ recorded at Otaraia.

Episode (6) was similar to episode 5 but longer in duration ( $34-32 \mathrm{ka} \mathrm{BP})$ with two low $\delta^{13} \mathrm{CO}_{2}$ values of $-9.8 \%$ and $-10.5 \%$ at 1.6 and $1.4 \mathrm{~m}$, respectively. This record closely correlates with a peak in the Vostok atmospheric $\mathrm{CH}_{4}$ concentration. Unlike the previous episodes, no clathrates releases are reported in the literature. However, because of the similarity in the magnitude and corresponding circumstances to the other events, it is also possible that a clathrate release to the atmosphere was responsible for this episode. 


\section{Chapter Five:}

\section{Summary and Conclusions}

This study has examined the use of phytoliths as a paleoenvironmental and paleoclimate proxy. It separates naturally into three sections, 1) a paleoenvironmental history of the lower Wairarapa valley over the last 120,000 years using variation in phytolith morphological assemblages extracted from a $7.4 \mathrm{~m}$ loess core, 2) the capture of the atmospheric $\delta^{13} \mathrm{CO}_{2}$ signal in the plant and phytolith carbon, and 3 ) the history of an ancient atmospheric $\delta^{13} \mathrm{CO}_{2}$ from phytolith-occluded carbon within the core. The paleoenvironmental reconstruction extends our understanding of how the vegetation mantling the Wairarapa landscape responded to the changes in past climate. A new method of extracting an atmospheric ${ }^{13} \mathrm{CO}_{2}$ signal from plant carbon sealed within silica phytoliths is used to derive an atmospheric $\delta^{13} \mathrm{CO}_{2}$ record for the last glacial cycle.

Phytoliths encapsulate carbon as they form in living plants. This material contains a record of the atmospheric carbon dioxide absorbed by a plant during photosynthesis. Following isotopic analysis of $\delta^{13} \mathrm{C}$, a number of internal and external factors that contribute to the raw isotopic phytolith signal are subtracted to reveal the atmospheric $\delta^{13} \mathrm{CO}_{2}$ signal from the time the plant was growing.

While phytoliths are more difficult to relate to plant species they do well in detecting vegetation change, and have other significant advantages over pollen. In particular, phytoliths are more resistant to decomposition than pollen, which can only be preserved in anaerobic environments such as bog and swamps. Because of their silica composition, phytoliths are better preserved than pollen in most New Zealand sedimentary deposits and able to provide long unbroken records of environmental conditions through time. However, it should be noted, that in spite of their limited resolution, in terms of being able to identify individual species, they can give a very good indication as to the respective percentages of grasses, trees and shrubs, and ferns occupying a given environment for a given period of time. Phytoliths are 
useful as a complement to other sources of paleoenvironmental information, and are especially useful in situations where there is little or no alternative data.

Prior to this study, our understanding of how the vegetation in the lower Wairarapa Valley responded to changes in climate was limited to a few scattered studies (Palmer et al. 1989, McLea 1990, Carter and Lian 2000). This work extends our knowledge, especially with regard to MIS 3. Phytolith morphological assemblages extracted from the Otaraia loess core were used to chart the changes in vegetation in response to climate changes during the last glacial cycle. The changes indicated by changes in the phytolith composition of the different zones are generally consistent with the Marine Isotope Stages of Martinson et al. (1987) and major temperature changes indicated in the Vostok ice-core of Petit et al. (1999). Furthermore, there is close agreement between the paleoenvironmental reconstruction of this study and a number of other New Zealand regional reconstructions using pollen analysis (McGlone and Topping 1983, Shulmeister et al. (2001), Okuda et al. (2002) and Vandergoes et al. 2005). However, there is a major break in sedimentation which represents the period from about $80 \mathrm{ka}$ to $58 \mathrm{ka}$. Ages from OSL samples bracketing this interval are expected in the near future. Notwithstanding these problems, this study provides one of the most complete vegetation-climate records yet determined for the last glacial-interglacial cycle in the North Island of New Zealand.

This thesis documents $\delta^{13} \mathrm{C}$ values from both leaves and within phytoliths from a number of modern New Zealand native plants (three species of grass, two species of tree fern, and ten species of tree). This study has found significant differences in carbon isotopic values between grasses and trees that are difficult to explain. They may relate to differences in carbon compounds present within phytolith-occluded carbon and differences in their concentration. The pilot NMR study in Chapter 3 indicates a likely path for resolving this issue. Nevertheless the study has been useful in establishing a consistent relationship between atmospheric $\delta^{13} \mathrm{CO}_{2}$ and that of occluded carbon in plant phytoliths.

This relationship was then applied to ancient phytoliths from the Otaraia loess core to obtain a record of ancient atmospheric ${ }^{13} \mathrm{CO}_{2}$ from plant carbon sealed within silica phytoliths. The record shows six periods (episodes) over the last 120,000 years when 
the earth's atmosphere had very low $\delta^{13} \mathrm{CO}_{2}$ values, which match methane peaks in the Vostok ice core. It is concluded that these episodes recorded as large negative ${ }^{13} \mathrm{CO}_{2}$ values are a consequence of the release of large volumes of methane into the atmosphere estimated for episode $3(\sim 85 \mathrm{ka})$ to have been about $9 \mathrm{GtC}$, diluting atmospheric ${ }^{13} \mathrm{CO}_{2}$ to such an extent that the effect is recorded in the carbon remains of plants.

It is acknowledged that the claims made in the preceding paragraph require further testing through replication in other loess sections, especially covering the last 40,000 years, where new $\mathrm{C}$ dating techniques offer potential for improving chronology. Further testing might involve the extraction of phytoliths from a different range of modern New Zealand plants and the occluded carbon analysed. In addition, identification of carbon compounds present within the occluded carbon from the same phytoliths should prove useful in better understanding the difference between phytolith carbon isotopic values between trees and grasses.

The presence of carbon encapsulated within phytoliths presents a source of material for radiocarbon dating material that is free of contamination. Although a number of phytolith-occluded radiocarbon ages have been published, there are still problems in their accuracy (Prior et al. 2005). If these were resolved then the method would greatly add to the utility of paleoenvironmental and paleoclimatic data from phytoliths. 


\section{Acknowledgements:}

I was particularly fortunate in receiving a grant from the Miss E.L. Hellaby Indigenous Grassland Research Trust, and would like to thank Professor Alan Mark and the Miss E.L. Hellaby Indigenous Grassland Research Trust for their financial support, without which, this study would have never been completed.

I give special thanks to Professor Peter J. Barrett for support, encouragement, critical analysis of the text, editing advice and encouragement.

I give special thanks to Dr Warren Dickinson for support, encouragement, advice and for making himself available to try out ideas and thoughts.

I thank Professor Euan Smith for statistical modelling advice.

I thank Professor Brad Pillans who introduced me to phytoliths.

I thank Dr James Shulmeister who encouraged me over the years in my pursuit of phytoliths.

I thank Dr Uwe Reiser and Ms Ningsheg Wang for their help in providing the OSL ages.

I thank Dr Alan Palmer for kindly allowing me access to the Otaraia core.

I thank Dr Christine Prior and the staff at the Rafter Laboratory of the Geological and Nuclear Sciences for their help in carbon isotope analysis.

I thank Dr John Patterson for help in microprobe photography.

I thank Associate Professor Ken MacKenzie for his help in organising NMR analysis and advice.

I thank the staff at Otari Plant Museum, Wellington for help in with identification and sampling of native plant samples.

I thank Dr Stephen Zitzer for providing Bromus samples.

Finally but not least I give special thanks my wife Jane von Dadelszen for encouragement, support and for indulging me in this pursuit and my son Rowan for his encouragement, patience and support. 


\section{References:}

Adams, J.M., Faure, H. 1998. A new estimate of changing carbon storage on land since the Last Glacial Maximum, based on land ecosystem reconstruction. Global and Planetary Change 16-17, 3-24.

Adams, J.M., Maslin, M., Thomas, E. 1999. Sudden climate transitions during the Quaternary. Progress in Physical Geography 23 (1), 1-36.

Alloway, B.V., Almond, P.C., Augustinas, P.C., Barrell, D.J.A., Bertler, NA.N., Carter, L., Litchfield, N.J., Lowe, D.J., McGlone, M.S., Newnham, R.M., Shulmeister, J., Vandergoes, M.J., Williams, P.W. 2006. Towards a climate event stratigraphy for New Zealand over the past 30,000 years (NZ-INTIMATE project). Journal of Quaternary Research 22 (1), 9-35.

Alexandre, A., Meunier, J.-D., Lézine, A.-M., Vincens, A., Schwartz, D. 1997. Phytoliths: indicators of grassland dynamics during the late Holocene in intertropical Africa.

Palaeogeography, Palaeoclimatology, Palaeoecology, 136, 213-229.

Arens, N.C., Jahren, A.H., Amundson, R. 2000. Can C3 plants faithfully record the carbon isotopic composition of atmospheric carbon dioxide? Paleobiology 26(1), 137-164.

Bartoli, F., Wilding, L.P. 1980. Dissolution of biogenic opal as a function of its physical and chemical properties. Soil Science Society of America Proceedings 44, 873-878.

Baxter, J.K. 1979. The ngaio tree. Collected Poems. Oxford University Press, New Zealand.

Beering, D.J. 1999. New estimates of carbon transfer to terrestrial ecosystems between the last glacial maximum and the Holocene. Terra Nova 11, 162-167.

Bender, M., Sowers, T., Labeyrie, L. 1994. The Dole effect and its variations during the Last 130,000 Years as measured in the Vostok Ice Core. Biogeochemical Cycles 8, 363-376.

Benner, R., Fogle, M.L., Sprague, E.K., Hodson, R.E. 1987. Depletion of ${ }^{13} \mathrm{C}$ in lignin and its implications for stable isotope studies. Nature 329, 708-710.

Blinnikov, M., Busacca, A., Whitlock, C. 2001. A new 100,000-year phytolith record from the Columbia River Basin, Washington, USA. In: Phytolith: Applications in Earth Sciences and Human History (Eds., Meunier J.D. and Colin F.), 27-55. Balkema.

Blinnikov, M., Busacca, A., Whitlock, C. 2002. Reconstruction of the late Peistocene grassland of the Columbia Basin, Washington, USA. Palaeogeography, Palaeoclimatology, Palaeoecology, 177, 77-101.

Blunier, T., Chappellaz, J., Schwander, J., Dällenbach, A., Stauffer, B., Stocker, T.F., Raynaud, D., Jouzel, J., H.B. Clausen, H.B., Hammer, C.U., S.J. Johnsen, S.J. 1998. Asynchrony of Antarctic and Greenland climate change during the last glacial period. Nature 394, 739-743.

Bobrov, A.A.; Bobrova, E.K.; Alexeev, Ju.E. 2001. Biogenic silica in biosystematicspotential uses. In: Phytolith: Applications in Earth Sciences and Human History (Eds., Meunier J.D. and Colin F.), 279-288. Balkema. 
Bowdery, D., Hart, D.M., Lentfer, C., Wallis, L.A. 2001. A universal phytolith key. In: Phytolith: Applications in Earth Sciences and Human History (Eds., Meunier J.D. and Colin F.), 267-278. Balkema.

Bozarth, S.R. 1992. Classification of opal phytoliths formed in selected dicotyledons native to the Great Plains. In: Phytolith Systematics; Emerging Issues (Eds. Rapp J. and Mulholland S.C.) p. 193. Plenum Press.

Bradley, R.S. 1999. Paleoclimatology: reconstructing climates of the Quaternary. Academic Press, San Diego.

Brook, E.J., Harder, S., Severinghaus, J., Steig, E.J., Sucher, C.M. 2000. On the origin and timing of rapid changes in atmospheric methane during the last glacial period. Global Biogeochemical Cycles 14 (2), 559-572.

Buchmann, N., Kao,, W.Y., Ehleringer, J.R. 1997. Influence of stand structure on carbon-13 of vegetation, soils and canopy air within deciduous and evergreen forests in Utah (USA). Oecologia 110, 109-120.

Carle, C.J. 1946. Wairarapa, the first one hundred years of a great district

Carnelli, A.L.; Madella, M.; Theurillat, J-P.; Ammann, B. 2002. Aluminium in the opal silica reticule of phytoliths: a new tool in palaeoecological studies. American Journal of Botany 89, 346-351.

Carter, J.A. 1994: Phytolith analysis in paleoenvironmental reconstruction. Research Monograph No.5. ISBN 0113-1753. Department of Geography, VUW.

Carter, J.A. 2000. Phytoliths from loess in Southland, New Zealand. New Zealand Journal of Botany, 38, 325-332.

Carter, J.A. 2002. Phytolith analysis and paleoenvironmental reconstruction from Lake Poukawa core, Hawkes Bay, New Zealand. Global and Planetary Change, 33(3-4), 243-267.

Carter, J.A. 2003. Phytolith analysis of Ipomoea batatas (kumara) and Lagenaria siceraria (gourd) in New Zealand: a method of providing direct evidence of pre-historic farming in ancient Polynesia. In: Phytolith and starch research in the Australian-Pacific-Asian regions: the state of the art, ed. by Diane M. Hart and Lynley A. Wallis. terra australis 19, 127-136.

Carter, J.A. 2003. Vegetation changes following volcanic eruptive events from phytolith analysis from Lake Poukawa Core, Hawkes Bay, New Zealand. Acta Palaeontologica Sinica 42(1), 68-75.

Carter, J.A.2007. Phytoliths In: Encyclopedia of Quaternary Science, pub. Elsevier B.V. 2007. 
Carter, J.A. and Lian, O.B. 2000. Paleoenvironmental reconstruction from the last Interglacial using phytolith analysis, south eastern North Island, New Zealand. Journal of Quaternary Science. 15 (7), 733-743.

Cave, Y., Paddison, V. 1999. The Gardener's Encyclopaedia of New Zealand Native Plants Godwit, Auckland.

Chappellaz, J., Barnola, J.M., Raynaud, D., Korotkevich, Y.S., Lorius, C. 1990. Ice-core record of atmospheric methane over the past 160,000 Years. Nature 345, 127-131.

Comstock, J.P., Cooper, T.A., Ehleringer, J.R., 1988. Seasonal patterns of canopy development and carbon gain in nineteen warm desert shrub species. Oecologia 75, 327335 .

Connor, H.E., Macrae, A.H 1969. Montane and subalpine tussock grasslands in Canterbury. In: The Natural History of Canterbury, ed. G.A. Knox. Reed, Auckland

Cooper, A. pers com. 2005

Crowley, T.J. 1995. Ice Age terrestrial carbon changes revisited. Global Biogeochemical Cycles 9(3), 377-389.

Crowley, T.J. 1991. Ice Age carbon. Nature 352, 575-576.

Croxdale, J. 2001. Stomata. In: Encyclopedia of Life Sciences. Nature Publishing Group/ $\underline{\text { www.els.net }}$

Curry, W.B., Duplessy, J.C., Labeyrie, L.D., Shackleton, N.J. 1988. Changes in the distribution of $\delta^{13} \mathrm{C}$ of Deep Water $\Sigma \mathrm{CO}_{2}$ between the last glaciation and the Holocene. Paleoceanography 3 (3), 317-341.

Davidson, J.M. 1984. The Prehistory of New Zealand (270 p.) Longman Paul. Auckland.

Deines, P. 1980. Handbook of Isotopic Geochemistry. Elsevier, Amsterdam.

Denham, T.P.; Haberle, S.G.; Lentfer, C.; Fullagar, R.; Field, J.; Therin,; Porch, N.; Winsborough. 2003. Origins of agriculture at Kuk Swamp in the Highlands of New Guinea. Science 301, 189-193.

Duplessy, J.C., Shackleton, N., Fairbanks, R.G., Labeyrie, L., Oppo, D.W., Kallel, N. 1988. Deepwater source variations during the last glacial cycle and their impact on deepwater circulation. Palaeocenaography 3 (3) 343-360.

Edgar, E., Connor, H.E. 1999. Flora of New Zealand Volume V, Grasses. Manaaki Whenua Press, Lincoln. 
Eherleringer, J.R., Field, C.B., Lin, Z.F., Kuo, C.Y. 1986. Leaf carbon isotope ratio and mineral composition in subtropical plants along an irradiance cline. Oecologia 70, 520-526.

Eherleringer, J.R., Cooper, T.A. 1988. Correlations between carbon isotopes and microhabitat in desert plants. Oecologia 76, 562-566.

Ehleringer, J.R., Cerling, T.E. 1995. Atmospheric $\mathrm{CO}_{2}$ and the ratio of intercellular to ambient $\mathrm{CO}_{2}$ concentrations in plants. Tree Physiology, 15, 105-111.

Ehleringer, J.R., Phillips, S.L., Comstock, J.P. 1992. Seasonal variation in the carbon isotopic composition of desert plants. Functional Ecology 6, 396-404.

Ehrenburg C.G. 1854. Mikrogeologie. Leopold Voss.

EPICA Community Members 2004. Eight glacial cycles from an Antarctic ice core. Nature 429, 623-628.

Epstein, S., Krishnamurthy, R.V. 1990. Environmental information in the isotopic record in trees. Philosphical Transactions of the Royal Society London A. 330, 427-439.

Evans, J.R., von Caemmerer, S. 1996. Carbon dioxide diffusion inside leaves. Plant Physiology 110, 339-346.

Eyer, M., Leuenberger, M., Nyfeler, P., Stocker, T. 2003. Highly resolved $\delta 13 \mathrm{C}$ measurements on air of Antarctic ice cores. EGS - AGU - EUG Joint Assembly, Abstracts from the meeting held in Nice, France.

Eyre, S.R. 1967. Vegetation and Soils. (328 p.) Arnold, London.

Farquhar, G.D. 1997. Carbon dioxide and vegetation. Science 278, 1411.

Farquhar, G.D., O’Leary, M.H., Berry, J.H. 1982 . On the relationship between carbon isotope discrimination and the intercellular carbon dioxide concentration in leaves. Australian Journal of Plant Physiology 9, 121-137.

Farquhar, G.D.,Ehleringer, J.R., and Hubick, K.T. (1989). Carbon isotope discrimination and photosynthesis. Annual Review of Plant Physiology and Plant Molecular Biology 40, 503537.

Feng, X., and Epstein, S. (1995). Carbon isotopes of trees and from arid environments and implications for reconstructing atmospheric $\mathrm{CO}^{2}$ concentration. . Geochimica et Cosmochimica Acta 59, 2599-2608.

Fernandez-Armesto, F. 2000. Civilizations Macmillan, London.

Ferretti, D.F., Lowe, D.C., Martin, R.J., Brailsford, G.W. 2000. A new gas chromatographisotope ratio mass spectrometry technique for high-precision analysis of $\delta^{13} \mathrm{C}$ and $\delta^{18} \mathrm{O}$ in atmospheric $\mathrm{CO}_{2}$ from small air samples. Journal of Geophysical Research, Atmospheres 105, 6709-6718. 
Fisher, H., Wahlen, M., Smith, J., Mastroianni, D., Deck, B. 1999. Ice Core records of atmospheric $\mathrm{CO}_{2}$ around the last three glacial terminations. Science 283, 1712-1714.

Francey, R.J., Gifford, R.M., Sharkey, T.D., Weir, B. 1985. Physiological influences on carbon isotope discrimination in Huon Pine (Lagarostrobus franklinii). Oecologia 66, 211218.

Francois, L.N., Altabet, M.A., Yu, E-F., Sigman, D.M., Bacon, M.P., Frank, M., Bohrman, G., Bareille, G.L. 1997. Contribution of Southern Ocean surface-water stratification to low atmospheric $\mathrm{CO}_{2}$ concentrations during the last glacial period. Nature 389, 929-935.

Fredlund, G.G. 1993: Paleoenvironmental interpretations of stable carbon, hydrogen, and oxygen isotopes from opal phytoliths, Eustis Ash Pit, Nebraska. In: Current Research in Phytolith Analysis: Applications in Archaeology and Paleoecology, ed. by Deborah M. Pearsall and Dolores R. Piperno. MASCA Research Papers in Science and Archaeology, 10, 46-75.

Fredlund, G.G., Tieszen, L.L. 1994. Modern phytolith assemblages from the North American Great Plains Journal of Biogeography 21, 321-335

Fredlund, G.G., Tieszen, L.L. 1997. Phytolith and carbon isotope evidence for late Quaternary vegetation and climate change in the Southern Black Hills, South Dakota. Quaternary Research 47, 206-217.

Friedli, H., Lotscher, H. 1986. Ice core record of the ${ }^{13} \mathrm{C} /{ }^{12} \mathrm{C}$ ratio of atmospheric $\mathrm{CO}_{2}$ in the past two centuries. Nature 324, 237-238.

Friedlingstein, P., Fung, I., Holland, E., John, J., Brasseur, G., Erickson, D., Schimel, D. 1995. On the contribution of $\mathrm{CO}_{2}$ fertilization to the missing biospheric sink. Global Biogeochemical Cycles 9 (4), 541-556.

de Garidel-Thoron, T., Beaufort, L., Bassinot, F., Henry, P. 2004. Evidence for large methane releases to the atmosphere from deep-sea gas hydrate dissociation during the last glacial episode. Proceedings of the National Academy of Sciences USA. 101 (25), 91879192.

Garten, C.T.J., and Taylor, G.E.J. (1982). Foliar ${ }^{13} \mathrm{C}$ within a temperate deciduous forest: Spatial, temporal, and species sources variation. Oecologia 90, 1-7.

Geographx 2006.

URL: http://www.geographx.co.nz

Geiss, J.W. 1973. Biogenic silica in selected species of deciduous angiosperms. Soil Science 116(2), 113-119.

Ghani, M.A. 1974. Late Cenozoic vertical crustal movement in the central part of New Zealand. Unpublished PhD Victoria University of Wellington, Wellington, New Zealand.

Google Earth 2006.

URL: http://earth.google.com 
Gordon, H.W. 2000. An Investigation of an archaeological Maori Kumara cultivation Site, Okuora Farm, Canterbury, New Zealand. Unpublished BSc (Hons) Thesis, Geology

Department, University of Canterbury, Christchurch, New Zealand.

Grocke, D.R. 2002. The carbon isotope composition of ancient $\mathrm{CO}_{2}$ based on higher-plant organic matter. Philosophical Transactions of the Royal Society, London A 360, 633-658.

Guy, R.D., Reid, D.M., Krouse, H.R. 1980. Shifts in carbon isotope ratios of two $\mathrm{C}_{3}$ halotypes under natural and artificial conditions. Oecologia 44, 241-247.

Hart, D.M. 1988, Safe method for the extraction of plant opal from sediments. Search, 19, 293.

Hart, D.M. 2001. Elements occluded within phytoliths. In: Phytolith: Applications in Earth Sciences and Human History (Eds., Meunier J.D. and Colin F.), 313-316. Balkema.

Hart D.M. and Wallis L.A. 2003. Phytolith and Starch Research in the Australian-PacificAsian Regions: the State of the Art, Pandanus Books.

Hatte, C., Antoine, P., Fontugne, M., Rousseau, D-D., Zoller, L. 2001. $\delta^{13} \mathrm{C}$ of loess organic matter as a potential proxy for paleoprecipitation. Quaternary Research 55, 33-38.

Hays, J.D., Imbrie, J., Shackleton, N.J. 1976. Variations in the Earths Orbit: Pacemaker of the Ice Ages. Science 194, 1121-1131.

Heaton, T.H.E. (1999). Spatial, species and temporal variations in ${ }^{13} \mathrm{C} /{ }^{12} \mathrm{C}$ ratios of $\mathrm{C} 3$ plants: Implications for palaeodiet studies. Journal of Archaeological Science 26, 637-649.

Heusser, L.E. and van der Geer, G. 1994. Direct correlation of terrestrial and marine paleoclimatic records from four glacial-interglacial cycles - DSDP Site 594 Southwest Pacific. Quaternary Science Reviews, 13, 273-282.

Hill, R.D. 1963. The vegetation of the Wairarapa in mid-nineteenth Century. Tuatara 2(1), 83-89.

Hoefs, J. 1987. Stable Isotope Geochemistry ( $3^{\text {rd }}$. edition). Springer-Verlag, Berlin.

Honsono, M., Oba, Y., Sase, T., Utsugawa, T., Aoki, K. 1991. Holocene volcanic ash soils at Waimangu Road tephra section, North Island, New Zealand: Soil formation/vegetation relationships. The Quaternary Research (in Japanese) 30, 91-101.

Horrocks, M., Deng, Y., Ogdon, J., Sutton, D.G. 2000. A reconstruction of the history of a Holocene sand dune on Great barrier Island, northern New Zealand using pollen and phytolith analysis. Journal of Biogeography 27, 1269-1277.

Horrocks, M., and Irwin, G.J. 2003. Pollen, phytoliths and diatoms in prehistoric coprolites from Kohika, Bay of Plenty, New Zealand. Journal of Archaeological Science 30, 13-20. 
Horrocks, M., Jones, M.D., Carter, J.A., Sutton, D.G. 2000. Pollen and phytoliths in stone mounds at Pouerua, Northland, New Zealand. Antiquity 74, 863-872.

Huang, Y., Street-Perrott, F.A., Metcalfe, S.E., Brenner, M., Moreland, M., Freeman, K.H. 2001. Climate change as the dominant control on glacial-interglacial variations in C3 and C4 plant abundance. Science 293, 1647-1651.

Indermühle, A., Stocker, T.F., Joos, F., Fischer, H., Smith, H.J., Wahlen, M., Deck, B., Mastroianni, D., Tcchumi, J., Blumier, T., Meyer, R., and Stauffer, B. 1999. Holocene carbon-cycle dynamics based on $\mathrm{CO}_{2}$ trapped in ice at Taylor Dome, Antarctica. Nature 398, 121-126.

Intergovernmental Panel on Climate Change. $4^{\text {th }}$ Assessment 2007.

URL: http://ipcc-wg1.ucar.edu

Jones, R.L., Beavers, A.H. 1963. Some mineralogical and chemical properties of plant opal. Soil Science 96, 375-379

Jones, L.H.P., Milne, A.A. 1963. Studies of silica in the oat plant I. chemical and physical properties of the silica. Plant and Soil 18, 207-220.

Kaplan, J.O., 2002 Wetlands at the last glacial maximum: distribution and methane emissions. Geophysical research Letters 29, 1029-1032.

Keeling, C.D, A.F. Bollenbacher, and T.P. Whorf. 2005. Monthly atmospheric ${ }^{13} \mathrm{C} /{ }^{12} \mathrm{C}$ isotopic ratios for 10 SIO stations. In Trends: A Compendium of Data on Global Change. Carbon Dioxide Information Analysis Center, Oak Ridge National Laboratory, U.S. Department of Energy, Oak Ridge, Tenn., U.S.A.

Kelly, E.F., Amundson, R.G., Marino, B.D., and Deniro, M.J. (1991). Stable isotope ratios of carbon in phytoliths as a quantitative method of monitoring vegetation and climate change. Quaternary Research 35, 222-233.

Kelly, E.F., Blecker, S.W., Yonker, C.M., Olson, C.G., Wohl, E.E., and Todd, L.C. (1998). Stable isotope composition of soil organic matter and phytoliths as paleoenvironmental indicators. Geoderma 82, 59-81.

Kennett, J.P., Cannariato, K.G., Hendy, I.L., Behl, R.J. 2003. Methane Hydrates in Quaternary Climate Change: The Clathrate Gun Hypothesis. American Geophysical Union Washington DC.

Kennett, J.P., Cannariato, K.G., Hendy, I.L., Behl, R.J. 2000. Carbon isotopic evidence for methane hydrate instability during Quaternary Interstadials. Science 288, 128-133.

Köhler, P., Schmitt, J., Fischer, H. 2006. On the application and interpretation of Keeling plots in paleo climate research-deciphering $\delta^{13} \mathrm{C}$ of atmospheric $\mathrm{CO}_{2}$ measured in ice cores. Biogeosciences Discussions 3, 513-573. 
Kondo, R., Childs, C.W. and Atkinson, I.A.E. 1994. Opal Phytoliths of New Zealand. Manaaki Whenua Press, Lincoln.

Krishnamurthy, R.V., Epstein, S. 1990. Glacial-interglacial excursion in concentration of atmospheric $\mathrm{CO}_{2}$ : Effect in the ${ }^{13} \mathrm{C} /{ }^{12} \mathrm{C}$ ratio in wood cellulose. Tellus $42 \mathrm{~B}, 423-434$.

Krull, E.S., Skjemstad, J.O., Graetz, D., Grice, K., Dunning, W., Cook, G., Parr, J.F. 2003.

${ }^{13} \mathrm{C}$-depleted charcoal from $\mathrm{C} 4$ grasses and the role of occluded carbon in phytoliths.

Organic Geochemistry 34, 1337-1352.

Kvenvolden, K.A., Lorenson, T.D. 2001. The global occurrence of natural gas hydrate. In Natural Gas Hydrates: Occurrence, Distribution and Detection, ed. by C.K. Paull and W.P. Dillon. American Geophysical Union, Geophysical Monograph Series 124, 3-18.

Le Roux-Swarthout, D.J., Terwilliger, V.J., Martin C.E. 2001. Deviation between $\delta^{13}$ C and leaf intercellular $\mathrm{CO}_{2}$ in Salix interior cuttings developing under low light. International Journal of Plant Science 162(5), 1017-1024.

Leach, B.F. 1981. The prehistory of the Southern Wairarapa. Journal of the Royal Society of New Zealand 11(1), 11-33.

Leavitt, S.W., Long, A. 1983. An atmospheric ${ }^{13} \mathrm{C} /{ }^{12} \mathrm{C}$ reconstruction generated through removal of climate effects from tree-ring ${ }^{13} \mathrm{C}^{12} \mathrm{C}$ measurements. Tellus $B \mathbf{3 5}, 92$

Leavitt, S.W., Long, A. 1989. Drought indicated in carbon-13/carbon-12 of southwestern tree rings. Water Resources Bulletin WARBAQ 25 (2), 341-347.

Leavitt, S.W., Long, A. 1991. Seasonal stable isotope variability in tree rings: possible paleoenvironmental signals. Chemical Geology 87(1), 59-70.

Leuenberger, M., Siegenthaler, U., Langway, C.C. 1992. Carbon isotope composition of atmospheric $\mathrm{CO}_{2}$ during the last ice age from an Antarctic ice core. Nature 357, 488-490.

Leuenberger, M., Eyer, M., Nyfeler, P., Stauffer, B., Stocker, T.F. 2003. High resolution $\delta^{13} \mathrm{C}$ measurements on ancient air extracted from less than $10 \mathrm{~cm}^{3}$ of ice. Tellus $\mathbf{5 5 ( B ) , ~ 1 3 8 - ~}$ 144.

Linsley, B.K. 1996. Oxygen-isotope record of sea-level and climate variations in the Sulu sea over the past 150,000 years. Nature 380, 234-237.

Lowden J, W Dyck 1974. Seasonal variation in the isotope ratios and carbon in maple leaves and other plants. Canadian Journal of Earth Sciences 11,79-88.

Lu, H., Yang, X., Liu, K.B., Xia, Z., Ren, X., Cai, L. 2005. Millet noodles in late Neolithic China. Nature 437, 967-968.

MacDonald, G.M., Beiman, D.W., Kremenetski, K.V., Sheng, Y., Smith, L.C., Velichko, A.A. 2006. Rapid early development of circumarctic peatlands and atmospheric $\mathrm{CH}_{4}$ and $\mathrm{CO}_{2}$ variations. Science 314, 285-288. 
Madella, M., Alexandre, A., and Ball, T. 2005. International code for phytolith nomenclature 1.0. Annals of Botany 96(2), 253-260.

Maptoaster 2006.

URL: http://www.maptoaster.com

Marino, B.D., McElroy, M.B. 1991. Isotopic composition of atmospheric $\mathrm{CO}_{2}$ inferred from carbon in C4 plant cellulose. Nature 349, 127-131.

Marino, B.D., McElroy, M.B., Salawitch, R.J., Spaulding, W.G. 1992. Glacial-tointerglacial variations in the carbon isotopic composition of atmospheric $\mathrm{CO}_{2}$. Nature 357, 461-466.

Martinson, D.G., Pisias, N.G., Hays, J.D., Imbrie, J., Moore, T.C., Shackleton, N.J. 1987. Age dating and orbital theory of the ice ages: development of a high resolution 0 to 300,000 year chronostratigraphy. Quaternary Research 27, 1-29.

Marx, R., Lee, D.E. 2004. Phytolith morphology and biogenic silica concentrations in leaves of Chionochloa (Danthonieae) and Festuca (Poeae) in New Zealand. New Zealand Journal of Botany 42, 677-691.

Maslin, M.A., Shackleton, N.J., Pflaumann, U. 1995. Surface water temperature, salinity, and density changes in the Atlantic during the last 45,000 years: Heinrich events, deep water formation, and climatic rebounds. Paleoceanography 10(3), 527-544.

Maslin, M.A., Thomas, E. 2003. Balancing the deglacial global carbon budget: the hydrate factor. Quaternary Science Reviews 22, 1729-1736.

Mbida, C.M.; Van Neer, W.; Doutrelepont, H.; Vrydaghs, L. 2000. Evidence for banana cultivation and animal husbandry during the first millennium BC in the forest of Southern Cameroon. Journal of Archaeological Science 27, 151-162.

McClaran, M.P., Umlauf, M. 2000. Desert grassland dynamics estimated from carbon isotopes in grass phytoliths and soil organic matter. Journal of Vegetation Science 11, 71-76.

McFadgen, B.G. 1980. A stone row system at Okoropunga on the Southeast Wairarapa Coast and inferences about coastal stone rows elsewhere in Central New Zealand. New Zealand Journal of Science, 23, 189-197.

McGlone, M.S. 1985. Biostratigraphy of the last interglacial-glacial cycle, southern North Island, New Zealand. In B.J. Pillans (ed.), Victoria University of Wellington Geology Department Misc. Publ. 31, 17-31.

McGlone, M.S. 1988. New Zealand. In Vegetation History, ed.by B. Huntley and T. Webb III. Kluwer Academic Publishers, London.

McGlone, M.S. and Topping, W.W. 1983. Late Quaternary vegetation, Tongariro region, central North Island, New Zealand. New Zealand Journal of Botany, 21, 53-76.

McGlone, M.S., Mildenhall, D.C., Pole, M.S. 1996. History and paleoecology of New Zealand Nothofagus forests. In The Ecology and Biogeography of Nothofagus, ed.by Veblen, TT; Hill, RS; Reid, R.B. Yale University Press, New Haven, Connecticut 
Meunier J.D. and Colin F. 2001. Phytolith: Applications in Earth Sciences and Human History, Balkema.

Milkov, A.V. 2004. Global estimates of hydrate-bound gas in marine sediments: how much is really out there? Earth Science Reviews 66, 183-197.

Milne, J.D.G. 1973. Maps and Sections of river terraces in the Rangitiki Basin, North Island, New Zealand. N.Z. Soil Survey Report 4.

Milne, J.D.G., Smalley, I.J. 1979. Loess deposits in the southern part of New Zealand: an outline of stratigraphy. Acta Geologia Academiae Scientiarum Hungaricae 22(1-4), 197-204.

Milo, C., Sarnthein, M., Erienkeuser, H., Frederichs, T. 2005. Methane-driven late Pleistocene $\delta^{13} \mathrm{C}$ minima and overflow reversals in the southwestern Greenland Sea. Geology 33 (11), 873-876.

Moar, N.T. and Suggate R.P. 1996. Vegetation history from the Kaihinu (last) interglacial to the present, West Coast, South Island, New Zealand. Quaternary Science Reviews, 15, 521547.

Monnin, E et al. 2004. Evidence for substantial accumulation rate variability in Antarctica during the Holocene, through synchronization of $\mathrm{CO}_{2}$ in the Taylor Dome, Dome $\mathrm{C}$ and DML ice cores. Earth and Planetary Science Letters 224 45-54.

Mooney, H.A., Chu, C. 1974. Seasonal carbon allocation in Heteromeles arbutifolia, a California evergreen shrub. Oecologia 14(4), 295-306.

Mulholland, S.C., C.A. Prior, C.A. 1993: AMS radiocarbon dating of phytoliths. In: Current Research in Phytolith Analysis: Applications in Archaeology and Paleoecology, ed. by Deborah M. Pearsall and Dolores R. Piperno. MASCA Research Papers in Science and Archaeology, 10, 21-23.

NIWA CliFlo: National Climate Database on the WEB

URL: http://cliflo.niwa.co.nz

Retrieved date 8-August-2006

Newnham, R.M. 1999. Environmental change in Northland, New Zealand during the last glacial and Holocene. Quaternary International, 57/58, 61-70.

New Zealand Historical Atlas 1997. Eds. M. Mckinnon, B. Bradley, R. Kirkpatrick. David Bateman, Auckland.

Nisbet, E.G. 1990. The End of the Ice Age. Canadian Journal of Earth Science 27, 148-157.

Nisbet, E.G. 2002. Have sudden large releases of methane from geological reservoirs occurred since the Last Glacial Maximum, and could such releases occur again?

Philosophical Transactions: Mathematical, Physical and Engineering Sciences 360(1793, 581-607. 
Ogden, J., Stewart, G.H., Allen, R.B. 1996. Ecology of New Zealand Nothofagus forests. In Vegetation History. In The Ecology and Biogeography of Nothofagus, ed.by Veblen, TT; Hill, RS; Reid, R.B. Yale University Press, New Haven, Connecticut

Okuda, M., Shulmeister J. and Flenley, J.R. 2002. Vegetation changes and their climatic implication for the late Pleistocene at Lake Poukawa, Hawkes Bay, New Zealand. Global and Planetary Change 33(3-4), 269-282.

O’Leary, MH. (1981). Carbon fractionation in plants. Phytochemistry 20, 553-567.

O’Leary, MH. (1988). Carbon isotopes in photosynthesis. Bioscience 38, 328-336.

Otto, D., Rasse, D., Kaplan, J., Warnant, P., Francois, L. 2002. Biospheric carbon stocks reconstructed at the last glacial maximum. Global and Planetary Change 33, 117-138.

Palmer, A. S. (1982). The stratigraphy and selected properties of loess in the Wairarapa, New Zealand. Unpublished PhD Victoria University of Wellington, Wellington, New Zealand.

Parr, J.F., Dolic, V., Lancaster, G., Boyd, W.E. 2001. A microwave digestion method for the extraction of phytoliths from herbarium specimens. Review of Palaeobotany and Palynology 116, 203-212.

Parr, J.F., 2002. A comparison of heavy liquid floatation and microwave digestion techniques for the extraction of fossil phytoliths from sediments. Review of Palaeobotany and Palynology 120, 315-336.

Pasquier-Cardin, A., Allard, P., Ferreira, T., Hatte, C., Coutinho, R., Fontugne, M., and Jaudon, M. (1999). Magma-derived $\mathrm{CO}^{2}$ emissions recorded in ${ }^{14} \mathrm{C}$ and ${ }^{13} \mathrm{C}$ content of plants growing in Furnas Caldera, Azores. Journal of Vulcanology and Geothermal Research 92, 195-207.

Pearsall, D.M. 2000. Paleoethnobotany, A Handbook of Procedures. $2^{\text {nd }}$ ed. Academic Press, San Diego.

Pearsall, D.M., Piperno, D.R. 1993. Current Research in Phytolith Analysis: Applications in Archaeology and Paleoecology, MASCA Research Papers in Science and Archaeology, 10.

Peng, C.H., Guiot, J. Van Campo, E. 1998. Estimating changes in terrestrial vegetation and carbon storage: using palaeoecological data and models. Quaternary Science Reviews 17, 719-735.

Petit, J.R., Jouzel, J., Raynaud, D., Barkov, N.I., Barnola, J-M., Basile, I., Bender, M., Chappellaz, J., Davis, M., Delaygue, G., Delmotte, M., Kotlyakov, V.M., Legrand, V. 1999. Climate and atmosphere history of the past 420,000 years from the Vostok ice core, Antarctica. Nature 399, 429-436.

Petit, J.R., et al., 2001, Vostok ice core data for 420,000 Years, IGBP PAGES/World Data Center for Paleoclimatology Data Contribution Series \#2001-076.

NOAA/NGDC Paleoclimatology Program, Boulder CO, USA. 
Pillans, B., McGlone, M., Palmer, A., Mildenhall, D., Alloway, B., Berger, G. 1993. The Last Glacial Maximum in central and southern North Island, New Zealand: a paleoenvironmental reconstruction using the Kawakawa Tephra Formation as a chronostratigraphic marker. Palaeogeography, Palaeoclimatology, Palaeoecology, 101, 283-304.

Piperno, D.R. 1988. Phytolith Analysis, An Archaeological and Geological Perspective. Academic Press, San Diego.

Piperno D.R. 2006. Phytoliths: A Comprehensive Guide for Archaeologists and Paleoecologists, Altamira Press.

Piperno, D.R., Holst, I., Wessel-Beaver, L., Andres, T.C. 2002. Evidence for the control of phytolith formation in Cucurbita fruits by the hard rind $(\mathrm{Hr})$ genetic locus: archaeological and ecological implications. Proceedings of the National Academy of Sciences USA 99, 10923-10928.

Polley, H.W., Johnson, H.B., Marino, B.D., Mayeux, H.S. 1993. Increase in C3 plant wateruse and biomass over glacial to present $\mathrm{CO}_{2}$ concentrations. Nature 361, 61-64.

Powers-Jones, A.H. and Padmore, J. 1993. The use of quantitative methods and statistical analyses in the study of opal phytoliths. In: Current Research in Phytolith Analysis:

Applications In Archaeology and Paleoecology. (eds. Pearsall D.M. and Piperno D.R.), p. 47. MASCA.

Prebble, M., Schallenberg, M., Carter, J.A., Shulmeister, J. 2002. An analysis of phytolith assemblages for the quantitative reconstruction of late Quaternary environments of the Lower Taieri Plain, Otago, South Island, New Zealand 1: modern assemblages and transfer functions. Journal of Paleolimnology 27, 393-413.

Prebble, M., Shulmeister, J. 2002. An analysis of phytolith assemblages for the quantitative reconstruction of late Quaternary environments of the Lower Taieri Plain, Otago, South Island, New Zealand 11: palaeoenvironmental reconstruction. Journal of Paleolimnology 27, 415-427.

Prentice, K.C., Fung, I.Y. 1990. The sensitivity of terrestrial carbon storage to climate change. Nature 346, 48-51.

Prior, C.A., Carter, J., and Rieser, W. 2005. Are phytolith radiocarbon dates reliable? $10^{\text {th }}$ International Conference on Accelerator Mass Spectrometry in San Francisco 2005.

Quinn, W.H., Neil, V.T. 1992. The historical record of El Nino events. In: Climate Since A.D. 1500, eds. R.S. Bradley and P.D. Jones. Routledge, London, 623-648.

Raeside, J.D. 1964. Loess deposits of the South Island, New Zealand, and soils formed on them. New Zealand Journal of Geology and Geophysics, 7-4, 811-838.

Raeside, J.D. 1970. Some New Zealand Plant Opals. New Zealand Journal Science. 13, $122-$ 132. 
Rapp, G. Jr. and Mulholland, S.C. 1992. Phytolith Systematics, Emerging Issues. Plenum Press, New York.

Raven, P.H., Evert, R.F., Eichhorn, S.E 1999. Biology of Plants. W.H. Freeman and Company, New York.

Read, S.A. and Hull, A.G. 1982. Lake Poukawa Drilling Project (LPDP-4). New Zealand Geological Initial Reports. IGNS Unpub. file 2pp + summary log.

Rieser, U., Carter J.A., Wang N., Prior C., Edsall D. 2005. Phytoliths, diatoms, and volcanic ashfalls - OSL dating of (more or less) amorphous substances. 11th International Conference on Luminescence and Electron Spin Resonance Dating Cologne 2005.

Rosen, A.M., Weiner, S. 1994. Identifying ancient irrigation: a new method using opaline phytoliths from emmer wheat. Journal of Archaeological Science 21, 125-132.

Rowlett, R.M. and Pearsall, D.M. 1993. Archaeological age determinations derived from opal phytoliths in thermoluminescence. In: Current Research in Phytolith Analysis: Applications In Archaeology and Paleoecology. (eds. Pearsall D.M. and Piperno D.R.), 25. MASCA.

Ruddimann, W.F., Vavrus, S.J. 2005. A test of the overdue-glaciation hypothesis. Quaternary Science Reviews 24, 1-10.

Sase, T. 1986. Plant opal analysis of Andisols in North Island, New Zealand. Pedologist 30, 2-12.

Sase, T., Hosono, M., Utsgawa, T. and Aoki K. 1988. Opal phytolith analysis of present and buried volcanic ash soils in Te Ngae Road tephra section, Rotorua Basin, North Island, New Zealand. The Quaternary Research, 27-3, (in Japanese with English summary, figures and tables).

Sase, T., Hosono, M. 2001. Phytolith record in soils interstratified with late Quaternary tephras overlying the eastern region of Towada Volcano, Japan. In: Phytoliths: Applications in Earth Science and Human History eds. Meunier, J.D., Colin, F., 57-71. A.A. Balkema Publishers, Lisse, Netherlands.

Schleser, G.H. 1990. Investigation of the $\delta^{13} \mathrm{C}$ patterns in leaves of Fagus sylvatica L. Journal of Experimental Botany 41/226, 565-575.

Schleser, G.H. 1995. Parameters determining carbon isotope ratios in plants. In: Problems of Stable Isotopes in Tree-rings, Lake Sediments and Peat Bogs as Climatic Evidence for the Holocene. eds. B. Frenzel, B. Stauffer and M.M. Weiß. Gustav Fischer Verlag, Stuttgart.

Schultz, K.E., and Adams, M.S. 1995. Effect of canopy gap light environment on evaporative load and stomatal conductance in temperate forest understory heb Aster macrophyllus (Asteraceae). Am. J. Bot. 82, 630-637.

Shackleton, N.J. 1977. The oxygen isotope stratigraphic record of the late Pleistocene. Philosophical Transactions of the Royal Society, London B 288, 169-182. 
Shahack-Gross, R., A. Shemesh, D. Yakir, S. Weiner 1996: Oxygen isotope composition of opaline phytoliths: Potential for terrestrial climatic reconstruction. Geochimica et Cosmochimica Acta 60(20), 3949-3953

Shulmeister, J., Soons, J. M., Berger, G. W., Harper, M., Holt, S., Moar, N., Carter, J. A. 1999. Environmental and sea-level changes on Banks Peninsular (Canterbury, New Zealand) through three glaciation-interglaciation cycles. Palaeogeography, Palaeoclimatology,

Palaeoecology, 152, 101-127.

Shulmeister, J., Shane, P.B., Lian, O.B., Okuda, M., Carter, J.A., Harper M.A., Dickinson, W., Augustinas, P. and Heijnis H. 2001. A long late-Quaternary record from Lake Poukawa, Hawkes Bay, New Zealand.. Palaeogeography, Palaeoclimatology, Palaeoecology 176, 81107.

Sigman, D.M., Boyle, E.A. 2000, Glacial/interglacial variations in atmospheric carbon dioxide. Nature 407, 859-869.

Smedley, M.P., Dawson, T.E., Comstock, J.P., Donovan, L.A., Sherrill, D.E., Cook, C.S., Ehleringer, J.R. 1991. Seasonal carbon isotope discrimination in grassland community. Oecologia 85, 314-320.

Smith, F.A., Anderson, K.B. 2001. Characterization of organic compounds in phytoliths: improving the resolving power of phytolith $\delta^{13} \mathrm{C}$ as a tool for paleoecological reconstruction of $\mathrm{C} 3$ and C4 grasses. In: Phytoliths: Applications in Earth Science and Human History eds. Meunier, J.D., Colin, F. 317-341. A.A. Balkema Publishers, Lisse, Netherlands.

Smith, F.A., White, J.W.C. 2004. Modern calibration of phytolith carbon signatures for $\mathrm{C}_{3} / \mathrm{C}_{4}$ paleograssland reconstruction. Palaeogeography, Palaeoclimatology, Palaeoecology 207, 277-304.

Smith, H.J., Fischer, H., Mastroianni, D., Deck, B. 1999. Duel mode of the carbon cycle since the Last Glacial Maximum. Nature 400, 248-250.

Smith, S.D., Osmond, C.B. 1987. Stem photosynthesis in desert ephemeral Eriogogum inflatum. Morphology, stomatal conductance and water use efficiency in field populations. Oecologia 72, 533-541.

Smith, S.D., Huxman, T.E., Zitzer, S.F., Charlet, T.N., Housman, D.C., Coleman, J.S., Fenstermaker, L.K., Seemann, J.R., Nowak, R.S. 2000. Elevated $\mathrm{CO}_{2}$ increases productivity and invasive species success in an arid ecosystem. Nature 408, 79-82.

Soons, J.M., Moar, N.T., Shulmeister, J., Wilson, H.T., Carter, J.A. 2002. Vegetation and climate changes on Banks Peninsula, South Island, New Zealand. Global and Planetary Change 33, 301-314. 
Stewart, G.R., Turnbull, M.H., Schmidt, S., and Eskine, P.D. (1995). ${ }^{13} \mathrm{C}$ natural abundance in plant communities along a rainfall gradient: A biological integrator of water availability. Australian Journal of Plant Physiology 22, 51-55.

Still, C.J., Berry, J.A., Collatz, G.J., Defries, R.S. 2003. Global distribution of C3 and C4 vegetation: carbon cycle implications. Global Biogeochemical Cycles 17 (1), 6-1.

Stringer, C., McKie, R. 1996. Africa Exodus: The Origins of Modern Humanity. Random House, London.

Stuiver, M., Burk, R.L., Quay, P.D. 1984. C-13/C-12 ratios in tree rings and the transfer of biospheric carbon to the atmosphere. Journal of Geophysical Research 89, 11731-11748.

Stuiver, M., Braziunas, T.F., Becker, B., Kromer, B. 1991. Climatic, solar, oceanic, and geomagnetic influences on late - glacial and atmospheric ${ }^{14} \mathrm{C} /{ }^{12} \mathrm{C}$ change. Quaternary Research 35, 1-24.

Teruggi, M.E. 1975: The nature and origin of Argentine loess. In: Loess Lithology and Genesis, ed. by Ian J. Smalley. Halstead Press, 195-208.

Thompson, C.S. 1992. The weather and climate of the Wairarapa Region. New Zealand Meteorological Service Miscellaneous Publication 115(11).

Thorn, V.C. 2006: Vegetation reconstruction from soil phytoliths, Tongariro National Park, New Zealand. New Zealand Journal of Botany 44, 397-413.

Troughton, J.H., Mooney, H.A., Berry, J.A., Verity, D. 1977. Variable carbon isotope ratios of Dudleya species growing in natural environments. Oecologia 30, 307-311.

Trudinger, C.M., Enting, I.G., Francey, R.J., Etheridge, D.M. 1999. Long-term variability in the global carbon cycle inferred from a high-precision $\mathrm{CO}_{2}$ and $\delta^{13} \mathrm{C}$ ice-core record. Tellus 51B, 233-248.

Turney, C.S.M., Hunt, J.E., Burrows, C. 2002. Deriving a consistent $\delta^{13}$ C signature from tree canopy leaf material for palaeoclimatic reconstruction. New Phytologist 155, 301-311.

Twiss, P.C. 2001. A curmudgeon's view of grass phytolithology. In: Phytolith: Applications in Earth Sciences and Human History (Eds., Meunier J.D. and Colin F.), 7. Balkema.

Vandergoes, M.J., Newnham, R.M., Preusser, F., Hendy, C.H., Lowell, T.V., Fitzsimons, S.J., Hogg, A.G., Kasper, H.U., Schlucter, C. 2005. Regional insolation forcing of late Quaternary climate change in the Southern Hemisphere. Nature 436, 242-245.

van Campo, E; Guiot, J; Peng, C. 1993. A data-based re-appraisal of the terrestrial carbon budget at the Last Glacial Maximum. Global and Planetary Change 8 (4), 189-201.

van de Water, PK., Leavitt, S.W., and Betancourt, J.L. (1994). Trends in stomatal density and ${ }^{13} \mathrm{C} /{ }^{12} \mathrm{C}$ ratios of Pinus flexilis needles during the last glacial-interglacial cycle. Science 264, 239-243.

van Hussteden, J. 2004. Methane emission from northern wetlands in Europe during Oxygen Isotope Stage 3. Quaternary Science Reviews 23, 1989-2005. 
Veblan, T.T., Hill, R.S., Read, J. 1996. The Ecology and Biogeography of Nothofagus

Forests. Yale University Press, New Haven.

Vella, P. 1963. Upper Pleistocene succession in the inland part of Wairarapa Valley, New Zealand. Transactions of the Royal Society of New Zealand 2(4), 63-78.

Vogel, J.C. 1978. Recycling of carbon in a forest environment. Ecologia Plantarum 13 (1), 89-94.

Wakefield, E.J. 1845. Illustrations to Adventure in New Zealand. Smith and Elder, London.

Wallis, L.A. 2003. An overview of leaf phytolith production patterns in selected northwest Australian flora. Review of Paleobotany and Palynology 125, 201-208.

Wardle, P. 1967. Vegetation of the Aorangi Range, Southern Wairarapa. New Zealand Journal of Botany 5, 22-48.

Wardle, P. 1991. Vegetation of New Zealand. University Press, Cambridge.

Weatherhead, A.V. 1988. The occurrence of plant opal in New Zealand soils. N.Z. Soil Bureau Record 108. Department of Scientific and Industrial Research, New Zealand.

Webb, E.A., Longstaffe, F.J. 1997. Oxygen isotope geochemistry of silica phytoliths. In: The State-of-the-Art of Phytoliths in Soils and Plants. ed. by A. Pinilla, J. Juan-Tresserras and M.J. Machado. Monografias del Centro de Ciencias Medioambientales, Con Superior de Investigaciones Ceientificas, Madrid, 233-244.

Webb, E.A. and Longstaffe F.J. 2002. Climatic influences on the isotopic composition of biogenic silica in prairie grass. Geochimica et Cosmochimica Acta 66(11), 1891-1904.

Webb, E.A. and Longstaffe F.J. 2003. The relationship between phytolith and plant water $\delta^{18} \mathrm{O}$ values in grasses. Geochimica et Cosmochimica Acta 67(8), 1437-1449.

Webb, E.A. and Longstaffe F.J. 2006. Identifying the $\delta^{18} \mathrm{O}$ signature of precipitation in grass cellulose and phytoliths: refining the paleoclimate model. Geochimica et Cosmochimica Acta 70, 2417-2416.

Weitemeyer, L.A., Buffett, B.A. 2006. Accumulation and release of methane from clathrates below the Laurentide and Cordilleran Ice Sheets. Global and Planetary Change 53, 176-187.

Whiticar, M.J., 1993. Stable isotopes and global budgets. In: M. A. K. Khalil (eds.) Atmospheric Methane: Sources, Sinks, and Role in Global Change, NATO ASI Series I, Global Environmental Change 13, Ch. 8, 138-67.

Wilding, L.P. 1967: Radiocarbon dating of biogenetic opal. Science 156, 66-67

Williams, P.W., King, D.N.T., Zhao, J.-X.., Collerson, K.D. 2005. Late Pleistocene to Holocene composite speleothem ${ }^{18} \mathrm{O}$ and ${ }^{13} \mathrm{C}$ chronologies from South Island, New Zealand did a global Younger Dryas really exist? Earth and Planetary Science Letters 230, 301-317. 
Wilmshurst, J.M. 1997. The impact of human settlement on vegetation and soil stability in Hawkes Bay, New Zealand. New Zealand Journal of Botany 35, 97-111.

Woillard, G. 1979. Abrupt end of the last interglacial s.s. in north-east France. Nature 281, $558-562$

Woodward, F.I. 1993. Plant responses to past concentrations of $\mathrm{CO}_{2}$. Vegetatio, 104/105, $145-155$.

Wright, I.C., McGlone, M.S., Nelson, C.S., Pillans, B.J. 1995. An integrated latest Quaternary (stage 3 to present) paleoclimatic and paleocenographic record from offshore Northern New Zealand. Quaternary Research 44 283-293.

Yakair, D., and Israeli, Y. (1995). Reduced solar irradiance effects on net primary productivity (NPP) and ${ }^{13} \mathrm{C}$ and ${ }^{18} \mathrm{O}$ Values in plantations of Musa Sp., Musaceae. Geochimica et Cosmochimica Acta 59, 2149-2151.

Zhao, Z., Piperno, D.R. 2000. Late Peistocene/Holocene environments in the middle Yangtze River Valley, China and Rice (Oryza sativa L.) domestication: the phytolith evidence. Geoarchaeology 15, 203-222. 


\section{Appendix 1:Luminescence Dating of 3 Samples (Technical Report 05/7)}

report by: Dr. Uwe Rieser

Luminescence Dating Laboratory / School of Earth Sciences

Victoria University of Wellington

e-mail: uwe.rieser@vuw.ac.nz

tel: 0064-4-463-6125

fax: 0064-4-463-5186

\section{Summary}

3 samples (laboratory code WLL458-460) were submitted for Luminescence Dating by John Carter (VUW). The deposition ages have been determined for all samples using the silt fraction. The palaeodose, i.e. the radiation dose accumulated in the sample after the last light exposure (assumed at deposition), was determined by measuring the blue luminescence output during infrared optical stimulation (which selectively stimulates the feldspar fraction). The doserate was estimated on the basis of a low level gammaspectrometry measurement.

All measurements were done in Victoria Universities Dating Laboratory.

\section{Procedure / Luminescence measurements}

Sample preparation was done under extremely subdued safe orange light in a darkroom. Outer surfaces, which may have seen light during sampling, were removed and discarded.

The actual water content and the saturation content were measured using 'fresh' inside material.

The samples were treated with $10 \% \mathrm{HCl}$ to remove carbonates until the reaction stopped, then carefully rinsed with distilled water. Thereafter, all organic matter was destroyed with $10 \% \mathrm{H}_{2} \mathrm{O}_{2}$ until the reaction stopped, then carefully rinsed with distilled water. By treatment with a solution of sodium citrate, sodium bicarbonate and sodium dithionate iron oxide coatings were removed from the mineral grains and then the sample was carefully rinsed again.

The grain size 4-11 $\mu \mathrm{m}$ was extracted from the samples in a water-filled (with added dispersing agent to deflocculate clay) measuring cylinder using Stokes' Law. The other fractions were discarded. The samples then are brought into suspension in pure acetone and deposited evenly in a thin layer on 70 aluminum discs ( $1 \mathrm{~cm}$ diameter). Luminescence measurements were done using a standard Riso TL-DA15 measurement system, equipped with Kopp 5-58 and Schott BG39 optical filters to select the luminescence blue band. Stimulation was done $\mathrm{cw}$ at about $30 \mathrm{~mW} / \mathrm{cm}^{2}$ with infrared diodes at $880 \Delta 80 \mathrm{~nm}$. $\beta$-irradiations were done on a Daybreak $801 \mathrm{E}$ ${ }^{90} \mathrm{Sr},{ }^{90} \mathrm{Y} \beta$-irradiator, calibrated against SFU, Vancouver, Canada to about 3\% accuracy. $\alpha$-irradiations were done on a ${ }^{241} \mathrm{Am}$ irradiator supplied and calibrated by ELSEC, Littlemore, UK.

The Paleodoses were estimated by use of the multiple aliquot additive-dose method (with late-light subtraction). After an initial test-measurement, 30 aliquots were $\beta$ irradiated in six groups up to six times of the dose result taken from the test. 9 aliquots were $\alpha$-irradiated in three groups up to three times of the dose result taken from the test. These 39 disks were stored in the dark for four weeks to relax the crystal lattice after irradiation. 
After storage, these 39 disks and 9 unirradiated disks were preheated for $5 \mathrm{~min}$ at $220 \mathrm{C}$ to remove unstable signal components, and then measured for $100 \mathrm{sec}$ each, resulting in 39 shinedown curves. These curves were then normalized for their luminescence response, using $0.1 \mathrm{~s}$ shortshine measurements taken before irradiation from all aliquots.

The luminescence growth curve ( $\beta$-induced luminescence intensity vs added dose) is then constructed by using the initial 10 seconds of the shine down curves and subtracting the average of the last $20 \mathrm{sec}$, the so called late light which is thought to be a mixture of background and hardly bleachable components. The shine plateau was checked to be flat after this manipulation. Extrapolation of this growth curve to the dose-axis gives the equivalent dose $\mathrm{D}_{\mathrm{e}}$, which is used as an estimate of the Paleodose.

A similar plot for the alpha-irradiated discs allows an estimate of the $\alpha$-efficiency, the a-value (Luminescence/dose generated by the $\alpha$-source divided by the luminescence/dose generated by the $\beta$-source).

\section{Fading test}

Samples containing feldspars in rare cases show an effect called anomalous fading. This effect inhibits accurate dating of the sample, as the electron traps in the crystal lattice of these feldspars are unable to store the age information over longer periods of time.

None of your samples gave an indication of this problem so far, but a routine test must be carried out after 6 months storage of an irradiated subsample to be sure. Thus, all ages reported below must be seen as preliminary until the fading test has been carried out. You will be notified by e-mail about the result.

\section{Procedure / Gamma spectrometry}

The dry, ground and homogenised soil samples were encapsuled in airtight perspex containers and stored for at least 4 weeks. This procedure minimizes the loss of the short-lived noble gas ${ }^{222} \mathrm{Rn}$ and allows ${ }^{226} \mathrm{Ra}$ to reach equilibrium with its daughters ${ }^{214} \mathrm{~Pb}$ and ${ }^{214} \mathrm{Bi}$.

The samples were counted using high resolution gamma spectrometry with a broad energy Ge detector for a minimum time of $24 \mathrm{~h}$. The spectra were analysed using GENIE2000 software.

The doserate calculation is based on the activity concentration of the nuclides ${ }^{40} \mathrm{~K}$, ${ }^{208} \mathrm{Tl},{ }^{212} \mathrm{~Pb},{ }^{228} \mathrm{Ac},{ }^{214} \mathrm{Bi},{ }^{214} \mathrm{~Pb},{ }^{226} \mathrm{Ra}$. 


\section{Results}

Table1: Doserate contribution of cosmic radiation

\begin{tabular}{|c|c|c|c|}
\hline $\begin{array}{c}\text { Sample } \\
\text { no. }\end{array}$ & $\begin{array}{c}\text { depth } \\
\text { below } \\
\text { surface }(\mathrm{m})\end{array}$ & $\begin{array}{c}\mathrm{dD}_{\mathrm{c}} / \mathrm{dt} \\
(\mathrm{Gy} / \mathrm{ka})^{1}\end{array}$ & Field code \\
\hline WLL458 & 3.0 & $0.1376 \pm 0.0069$ & JAC030 \\
\hline WLL459 & 4.9 & $0.1086 \pm 0.0054$ & JAC049 \\
\hline WLL460 & 7.0 & $0.0855 \pm 0.0043$ & JAC070 \\
\hline
\end{tabular}

${ }^{1}$ Contribution of cosmic radiation to the total doserate, calculated as proposed by Prescott \& Hutton (1994), Radiation Measurements, Vol. 23.

Table2: Radionuclide and water contents

\begin{tabular}{|c|c|c|c|c|c|c|c|}
\hline $\begin{array}{c}\text { Sample } \\
\text { no. }\end{array}$ & $\begin{array}{c}\text { Water } \\
\text { content } \\
\delta^{1}\end{array}$ & $\begin{array}{c}\mathrm{U}(\mu \mathrm{g} / \mathrm{g}) \\
\text { from }{ }^{234} \mathrm{Th}\end{array}$ & $\begin{array}{c}\mathrm{U}(\mu \mathrm{g} / \mathrm{g})^{2} \\
\text { from }{ }^{226} \mathrm{Ra},\end{array}$ & $\begin{array}{c}\mathrm{U}(\mu \mathrm{g} / \mathrm{g}) \\
\text { from }{ }^{210} \mathrm{~Pb}\end{array}$ & $\begin{array}{c}\mathrm{Th}(\mu \mathrm{g} / \mathrm{g})^{2} \\
\text { from }{ }^{208} \mathrm{Tl},\end{array}$ & $\mathrm{K}(\%)$ & $\begin{array}{c}\text { Field } \\
\text { code }\end{array}$ \\
\hline WLL458 & $\mathbf{1 . 1 4 3}$ & $\mathbf{2 . 4 9} \pm \mathbf{0 . 2 6}$ & $\mathbf{1 . 9 0} \pm \mathbf{0 . 1 7}$ & $\mathbf{1 . 8 3} \pm \mathbf{0 . 2 3}$ & $\mathbf{7 . 2 5} \pm \mathbf{0 . 1 1}$ & $\mathbf{1 . 4 9} \pm \mathbf{0 . 0 4}$ & JAC030 \\
\hline WLL459 & $\mathbf{1 . 1 9 2}$ & $\mathbf{3 . 1 1} \pm \mathbf{0 . 2 0}$ & $\mathbf{2 . 9 6} \pm \mathbf{0 . 1 3}$ & $\mathbf{2 . 6 2} \pm \mathbf{0 . 1 6}$ & $\mathbf{1 0 . 2 1} \pm \mathbf{0 . 1 1}$ & $\mathbf{1 . 6 4} \pm \mathbf{0 . 0 3}$ & JAC049 \\
\hline WLL460 & $\mathbf{1 . 2 4 8}$ & $\mathbf{3 . 0 9} \pm \mathbf{0 . 3 1}$ & $\mathbf{2 . 8 5} \pm \mathbf{0 . 2 0}$ & $\mathbf{2 . 0 5} \pm \mathbf{0 . 2 7}$ & $\mathbf{1 2 . 4 4} \pm \mathbf{0 . 1 6}$ & $\mathbf{2 . 1 8} \pm \mathbf{0 . 0 5}$ & JAC070 \\
\hline
\end{tabular}

${ }^{1}$ Ratio wet sample to dry sample weight. Errors assumed $50 \%$ of $(\delta-1)$.

${ }^{2} \mathrm{U}$ and $\mathrm{Th}$-content is calculated from the error weighted mean of the isotope equivalent contents

Numbers marked in red: Minor radioactive disequilibrium (significant on $2 \sigma-$ level) between $226 \mathrm{Ra}$ and $210 \mathrm{~Pb}$ (probably due to

Radon escape from the sediment).

Table3: Measured a-value and equivalent dose, doserate and luminescence age

\begin{tabular}{|c|c|c|c|c|c|}
\hline Sample no. & a-value & $\mathrm{D}_{\mathrm{e}}(\mathrm{Gy})$ & $\mathrm{dD} / \mathrm{dt}(\mathrm{Gy} / \mathrm{ka})$ & OSL-age (ka) & Field code \\
\hline WLL458 & $0.043 \pm 0.002$ & $122.5 \pm 4.3$ & $2.74 \pm 0.14$ & $\mathbf{4 4 . 7} \pm \mathbf{2 . 7}$ & JAC030 \\
\hline WLL459 & $0.044 \pm 0.007$ & $322.7 \pm 11.8$ & $3.29 \pm 0.21$ & $\mathbf{9 8 . 2} \pm \mathbf{7 . 2}$ & JAC049 \\
\hline *WLL460 & $0.063 \pm 0.016$ & $438.2 \pm 15.8$ & $\begin{array}{c}3.77 \pm 0.33 \\
(3.89 \pm 0.33)\end{array}$ & $\begin{array}{c}\mathbf{1 1 6 . 3} \pm \mathbf{1 0 . 4} \\
\mathbf{( 1 1 2 . 6} \pm \mathbf{1 0 . 4 )}\end{array}$ & JAC070 \\
\hline
\end{tabular}

* This sample showed a radioactive disequilibrium (see table 2), and the given age was corrected accordingly. As the level of disequilibrium over time is unknown, this age is only a better estimate and cannot be seen as the 'true' age. In brackets the uncorrected doserates and ages are given, calculated under the invalid assumption that the samples were in radioactive equilibrium (226Ra contents used for calculation). 


\section{Appendix 2:Phytolith Counts from Otaraia Loess Samples}

\section{Phytoliths Extracted from Otaraia Loess Core}

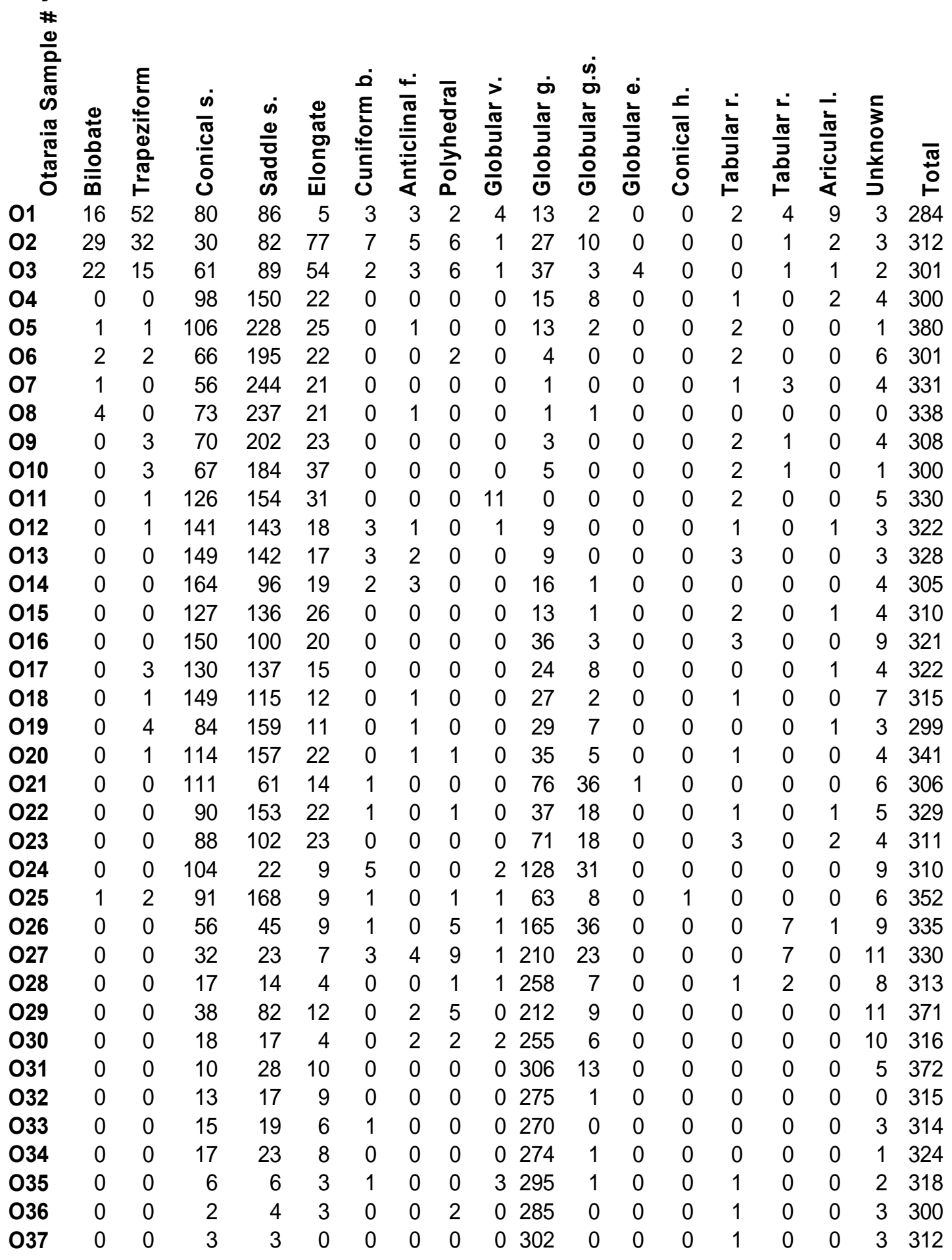




\section{Phytoliths Extracted from Otaraia Loess Core}

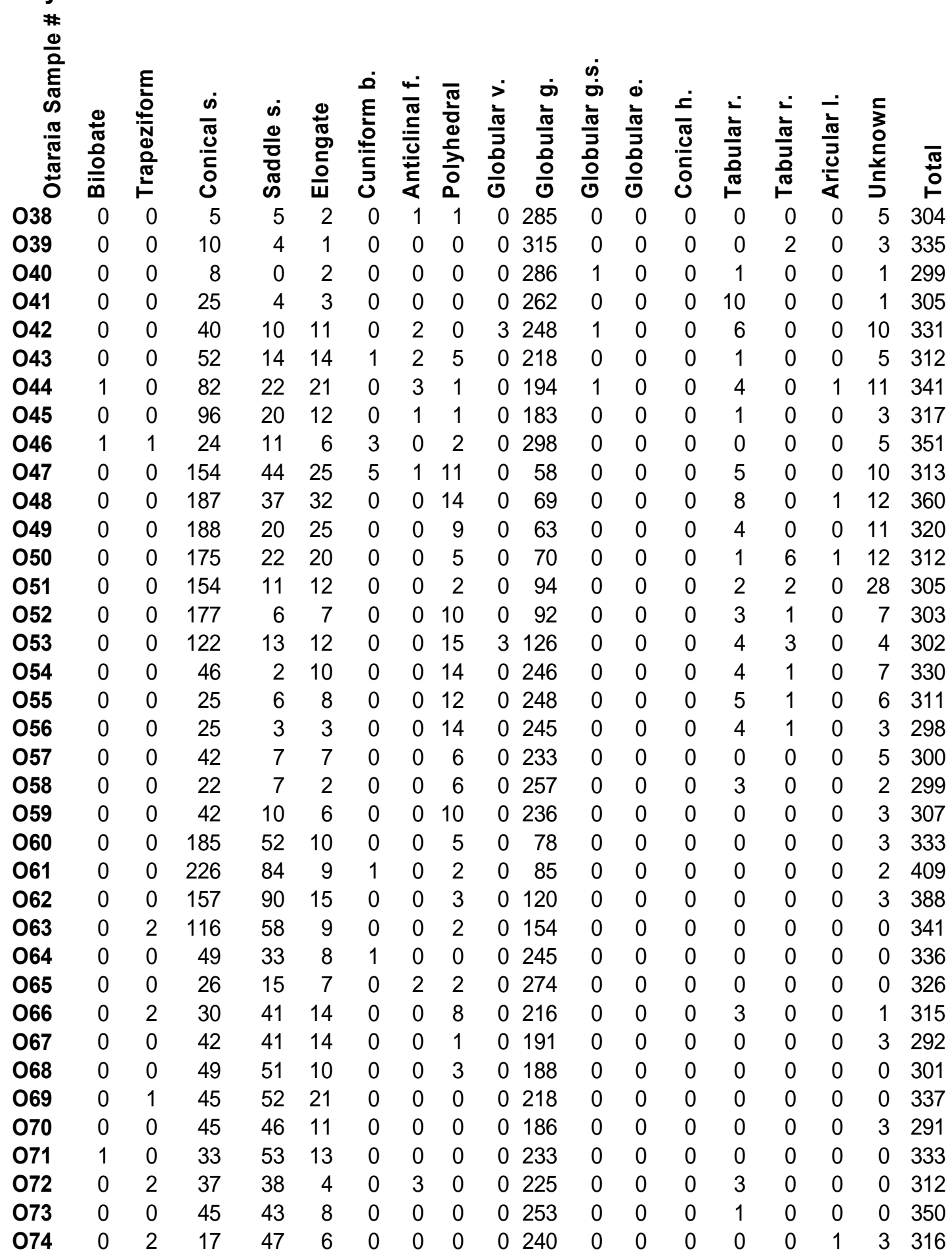




\section{Appendix 3: Analysis of 125,000 year Atmospheric $\delta^{13} \mathrm{CO}_{2}$ Record}

\section{Atmospheric $\mathbf{\delta 1 3 C}$ Calculation}

\begin{tabular}{|c|c|c|c|c|c|c|c|c|c|c|c|c|}
\hline 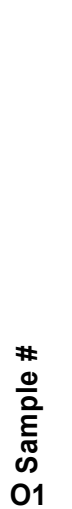 & 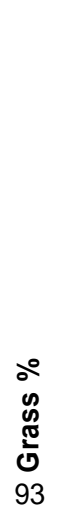 & 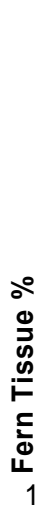 & 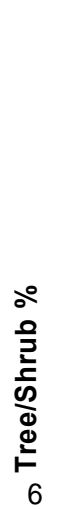 & 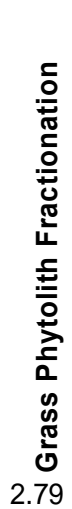 & 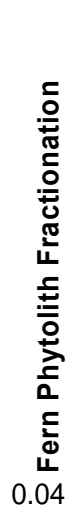 & 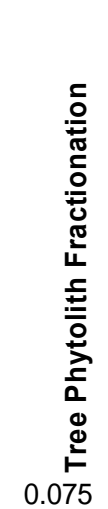 & 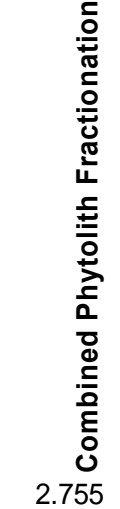 & 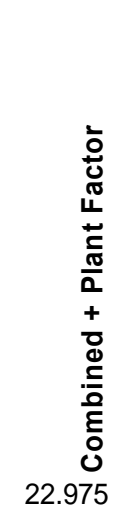 & 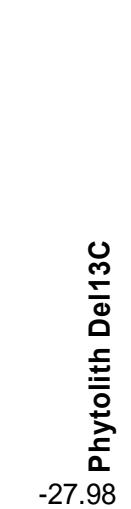 & 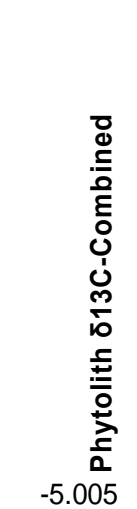 & 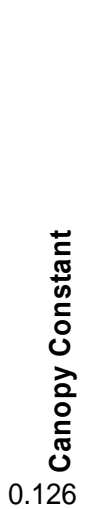 & 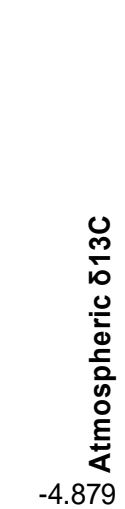 \\
\hline 02 & 83 & 2 & 15 & 2.49 & 0.08 & 0.1875 & 2.3825 & 22.6025 & -26.76 & -4.1575 & 0.315 & -3.8425 \\
\hline 03 & 83 & 1 & 16 & 2.49 & 0.04 & 0.2 & 2.33 & 22.55 & -29.1 & -6.55 & 0.336 & -6.214 \\
\hline 04 & 92 & 0 & 8 & 2.76 & 0 & 0.1 & 2.66 & 22.88 & -29.02 & -6.14 & 0.168 & -5.972 \\
\hline 05 & 95 & 1 & 4 & 2.85 & 0.04 & 0.05 & 2.84 & 23.06 & -29.58 & -6.52 & 0.084 & -6.436 \\
\hline 06 & 98 & 0 & 2 & 2.94 & 0 & 0.025 & 2.915 & 23.135 & -28.96 & -5.825 & 0.042 & -5.783 \\
\hline 07 & 99 & 0 & 1 & 2.97 & 0 & 0.0125 & 2.9575 & 23.1775 & -29.01 & -5.8325 & 0.021 & -5.8115 \\
\hline 08 & 99 & 0 & 1 & 2.97 & 0 & 0.0125 & 2.9575 & 23.1775 & -29.7 & -6.5225 & 0.021 & -6.5015 \\
\hline 09 & 99 & 0 & 1 & 2.97 & 0 & 0.0125 & 2.9575 & 23.1775 & -29.55 & -6.3725 & 0.021 & -6.3515 \\
\hline 010 & 98 & 0 & 2 & 2.94 & 0 & 0.025 & 2.915 & 23.135 & -29.43 & -6.295 & 0.042 & -6.253 \\
\hline 011 & 97 & 0 & 3 & 2.91 & 0 & 0.0375 & 2.8725 & 23.0925 & -30.29 & -7.1975 & 0.063 & -7.1345 \\
\hline 012 & 97 & 0 & 3 & 2.91 & 0 & 0.0375 & 2.8725 & 23.0925 & -30.5 & -7.4075 & 0.063 & -7.3445 \\
\hline 013 & 96 & 1 & 3 & 2.88 & 0.04 & 0.0375 & 2.8825 & 23.1025 & -31.76 & -8.6575 & 0.063 & -8.5945 \\
\hline 014 & 94 & 1 & 5 & 2.82 & 0.04 & 0.0625 & 2.7975 & 23.0175 & -33.64 & -10.6225 & 0.105 & -10.5175 \\
\hline 015 & 95 & 0 & 5 & 2.85 & 0 & 0.0625 & 2.7875 & 23.0075 & -31.74 & -8.7325 & 0.105 & -8.6275 \\
\hline 016 & 88 & 0 & 12 & 2.64 & 0 & 0.15 & 2.49 & 22.71 & -32.78 & -10.07 & 0.252 & -9.818 \\
\hline 017 & 91 & 0 & 9 & 2.73 & 0 & 0.1125 & 2.6175 & 22.8375 & -30.45 & -7.6125 & 0.189 & -7.4235 \\
\hline 018 & 90 & 0 & 10 & 2.7 & 0 & 0.125 & 2.575 & 22.795 & -30.59 & -7.795 & 0.21 & -7.585 \\
\hline 019 & 87 & 1 & 12 & 2.61 & 0.04 & 0.15 & 2.5 & 22.72 & -29.98 & -7.26 & 0.252 & -7.008 \\
\hline 020 & 88 & 0 & 12 & 2.64 & 0 & 0.15 & 2.49 & 22.71 & -30.18 & -7.47 & 0.252 & -7.218 \\
\hline 021 & 62 & 0 & 38 & 1.86 & 0 & 0.475 & 1.385 & 21.605 & -29.86 & -8.255 & 0.798 & -7.457 \\
\hline $\mathrm{O} 22$ & 84 & 0 & 16 & 2.52 & 0 & 0.2 & 2.32 & 22.54 & -30.14 & -7.6 & 0.336 & -7.264 \\
\hline 023 & 70 & 0 & 30 & 2.1 & 0 & 0.375 & 1.725 & 21.945 & -29.62 & -7.675 & 0.63 & -7.045 \\
\hline 024 & 46 & 0 & 54 & 1.38 & 0 & 0.675 & 0.705 & 20.925 & -32.13 & -11.205 & 1.134 & -10.071 \\
\hline 025 & 79 & 0 & 21 & 2.37 & 0 & 0.2625 & 2.1075 & 22.3275 & -30.43 & -8.1025 & 0.441 & -7.6615 \\
\hline 026 & 36 & 0 & 64 & 1.08 & 0 & 0.8 & 0.28 & 20.5 & -27.95 & -7.45 & 1.344 & -6.106 \\
\hline 027 & 21 & 1 & 78 & 0.63 & 0.04 & 0.975 & -0.305 & 19.915 & -28.07 & -8.155 & 1.638 & -6.517 \\
\hline 028 & 10 & 0 & 90 & 0.3 & 0 & 1.125 & -0.825 & 19.395 & -28.36 & -8.965 & 1.89 & -7.075 \\
\hline 029 & 37 & 2 & 61 & 1.11 & 0.08 & 0.7625 & 0.4275 & 20.6475 & -28.87 & -8.2225 & 1.281 & -6.9415 \\
\hline 030 & 12 & 1 & 87 & 0.36 & 0.04 & 1.0875 & -0.6875 & 19.5325 & -29.97 & -10.4375 & 1.827 & -8.6105 \\
\hline 031 & 14 & 0 & 86 & 0.42 & 0 & 1.075 & -0.655 & 19.565 & -30.62 & -11.055 & 1.806 & -9.249 \\
\hline 032 & 12 & 0 & 88 & 0.36 & 0 & 1.1 & -0.74 & 19.48 & -32.6 & -13.12 & 1.848 & -11.272 \\
\hline 033 & 13 & 0 & 87 & 0.39 & 0 & 1.0875 & -0.6975 & 19.5225 & -33.57 & -14.0475 & 1.827 & -12.2205 \\
\hline 034 & 14 & 0 & 86 & 0.42 & 0 & 1.075 & -0.655 & 19.565 & -33.7443 & -14.1793 & 1.806 & -12.3733 \\
\hline 035 & 5 & 0 & 95 & 0.15 & 0 & 1.1875 & -1.0375 & 19.1825 & -34.17 & -14.9875 & 1.995 & -12.9925 \\
\hline 036 & 3 & 0 & 97 & 0.09 & 0 & 1.2125 & -1.1225 & 19.0975 & -33.96 & -14.8625 & 2.037 & -12.8255 \\
\hline 037 & 2 & 0 & 98 & 0.06 & 0 & 1.225 & -1.165 & 19.055 & -33.89 & -14.835 & 2.058 & -12.777 \\
\hline
\end{tabular}




\begin{tabular}{|c|c|c|c|c|c|c|c|c|c|c|c|c|}
\hline 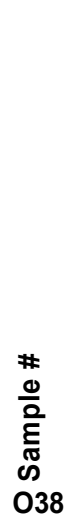 & $\begin{array}{l}\text { o̊ } \\
\text { d } \\
\text { ¿ँ } \\
0 \\
4\end{array}$ & 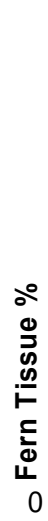 & 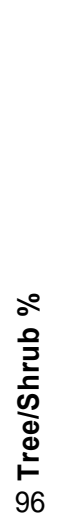 & 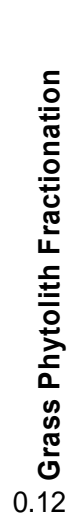 & 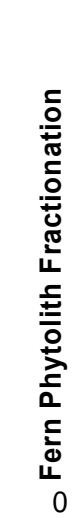 & 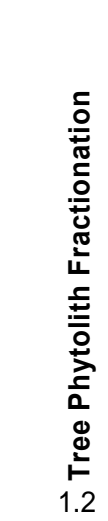 & 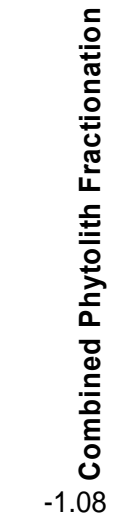 & 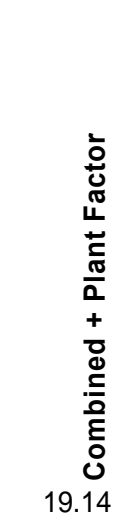 & 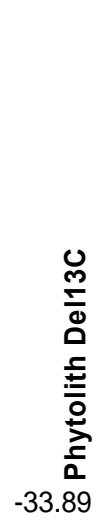 & 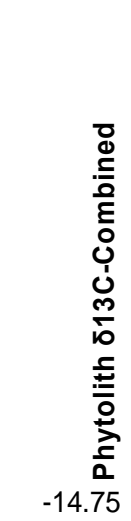 & 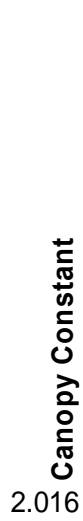 & 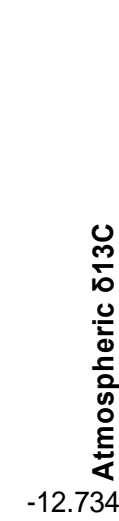 \\
\hline O39 & 4 & 0 & 96 & 0.12 & 0 & 1.2 & -1.08 & 19.14 & -33.7 & -14.56 & 2.016 & -12.544 \\
\hline 040 & 4 & 0 & 96 & 0.12 & 0 & 1.2 & -1.08 & 19.14 & -33.4 & -14.26 & 2.016 & -12.244 \\
\hline 041 & 11 & 0 & 89 & 0.33 & 0 & .1125 & -0.7825 & 19.4375 & -31.94 & -12.5025 & 1.869 & -10.6335 \\
\hline 042 & 19 & 0 & 81 & 0.57 & 0 & 1.0125 & -0.4425 & 19.7775 & -29.35 & -9.5725 & 1.701 & -7.8715 \\
\hline 043 & 26 & 1 & 73 & 0.78 & 0.04 & 0.9125 & -0.0925 & 20.1275 & -28.04 & -7.9125 & 1.533 & -6.3795 \\
\hline 044 & 39 & 1 & 60 & 1.17 & 0.04 & 0.75 & 0.46 & 20.68 & -29.1 & -8.42 & 1.26 & -7.16 \\
\hline 045 & 41 & 0 & 59 & 1.23 & 0 & 0.7375 & 0.4925 & 20.7125 & -28.73 & -8.0175 & 1.239 & -6.7785 \\
\hline 046 & 13 & 0 & 87 & 0.39 & 0 & 1.0875 & -0.6975 & 19.5225 & -28.87 & -9.3475 & 1.827 & -7.5205 \\
\hline 047 & 76 & 0 & 24 & 2.28 & 0 & 0.3 & 1.98 & 22.2 & -25.97 & -3.77 & 0.504 & -3.266 \\
\hline 048 & 76 & 0 & 24 & 2.28 & 0 & 0.3 & 1.98 & 22.2 & -26.77 & -4.57 & 0.504 & -4.066 \\
\hline 049 & 76 & 0 & 24 & 2.28 & 0 & 0.3 & 1.98 & 22.2 & -26.46 & -4.26 & 0.504 & -3.756 \\
\hline 050 & 73 & 0 & 2 & 2.19 & 0 & 3375 & 1.8525 & 22.0725 & -25.97 & -3.8975 & 0.567 & -3.3305 \\
\hline 051 & 66 & 0 & 34 & 1.98 & 0 & 0.425 & 1.555 & 21.775 & -28.42 & -6.645 & 0.714 & -5.931 \\
\hline 052 & 65 & 0 & 35 & 1.95 & 0 & 0.4375 & 1.5125 & 21.7325 & -28.94 & -7.2075 & 0.735 & -6.4725 \\
\hline 053 & 51 & 0 & 49 & 1.53 & 0 & 0.6125 & 0.9175 & 21.1375 & -27.45 & -6.3125 & 1.029 & -5.2835 \\
\hline 054 & 20 & 0 & 80 & 0.6 & 0 & 1 & -0.4 & 19.82 & -27.04 & -7.22 & 1.68 & -5.54 \\
\hline 055 & 14 & 0 & 86 & 0.42 & 0 & 1.075 & -0.655 & 19.565 & -27.35 & -7.785 & 1.806 & -5.979 \\
\hline 056 & 10 & 0 & 90 & 0.3 & 0 & 1.125 & -0.825 & 19.395 & -28.02 & -8.625 & 1.89 & -6.735 \\
\hline 057 & 18 & 0 & 82 & 0.54 & 0 & 1.025 & -0.485 & 19.735 & -28.9 & -9.165 & 1.722 & -7.443 \\
\hline 058 & 10 & 0 & 90 & 0.3 & 0 & 1.125 & -0.825 & 19.395 & -29.27 & -9.875 & 1.89 & -7.985 \\
\hline 059 & 19 & 0 & 81 & 0.57 & 0 & 1.0125 & -0.4425 & 19.7775 & -30.01 & -10.2325 & 1.701 & -8.5315 \\
\hline 060 & 75 & 0 & 25 & 2.25 & 0 & 0.3125 & 1.9375 & 22.1575 & -31.07 & -8.9125 & 0.525 & -8.3875 \\
\hline 061 & 78 & 0 & 2 & 2.34 & 0 & 0.275 & 2.065 & 22.285 & -32.33 & -10.045 & 0.462 & -9.583 \\
\hline 062 & 68 & 0 & 3 & 4 & 0 & 0.4 & 1.64 & 21.86 & -31.02 & -9.16 & 0.672 & -8.488 \\
\hline 063 & 54 & 0 & 46 & 1.62 & 0 & .575 & 1.045 & 21.265 & -30.47 & -9.205 & 0.966 & -8.239 \\
\hline 064 & 27 & 0 & 73 & 0.81 & 0 & 0.9125 & -0.1025 & 20.1175 & -30.49 & -10.3725 & 1.533 & -8.8395 \\
\hline 065 & 15 & 1 & 84 & 0.45 & .04 & 1.05 & -0.56 & 19.66 & -31.14 & -11.48 & 1.764 & -9.716 \\
\hline 066 & 29 & 0 & 71 & 0.87 & 0 & 0.8875 & -0.0175 & 20.2025 & -30.68 & -10.4775 & 1.491 & -8.9865 \\
\hline 067 & 33 & 0 & 67 & 0.99 & 0 & 0.8375 & 0.1525 & 20.3725 & -31.7 & -11.3275 & 1.407 & -9.9205 \\
\hline 068 & 36 & 0 & 64 & 1.08 & 0 & 0.8 & 0.28 & 20.5 & -31.12 & -10.62 & 1.344 & -9.276 \\
\hline 069 & 34 & 0 & 66 & 1.02 & 0 & .825 & 0.195 & 20.415 & -31.13 & -10.715 & 1.386 & -9.329 \\
\hline 070 & 35 & 0 & 65 & 1.05 & 0 & 0.8125 & 0.2375 & 20.4575 & -29.53 & -9.0725 & 1.365 & -7.7075 \\
\hline 071 & 30 & 0 & 70 & 0.9 & 0 & 0.875 & 0.025 & 20.245 & -31.39 & -11.145 & 1.47 & -9.675 \\
\hline 072 & 26 & 0 & 74 & 0.78 & 0 & 0.925 & -0.145 & 20.075 & -31.66 & -11.585 & 1.554 & -10.031 \\
\hline 07 & 27 & 0 & 73 & 0.81 & 0 & & -0.1025 & 20.1175 & -31.99 & -11.8725 & 1.533 & -10.3395 \\
\hline 074 & 23 & 0 & 77 & 0.69 & 0 & 0.9625 & -0.2725 & 19.9475 & -31.72 & -11.7725 & 1.617 & -10.1555 \\
\hline
\end{tabular}




\section{Appendix 4: Analysis of $\delta^{13} \mathrm{C}$ from Ancient Phytoliths}

Note: Owing to problems at the Rafter Laboratory many of the samples were spoilt and repeat samples were extracted from the original sediment samples and analysed. Therefore, many of the samples are designated by a " $R$ " or a "Rx". All samples marked in red were discarded and new samples extracted from the sediments and analysed.

John Carter Phytolith samples for $\delta^{13} \mathrm{C}$ only: R 28770/1-8

\begin{tabular}{|c|c|c|c|c|c|}
\hline Sample ID & $\begin{array}{c}\text { Rafter } \\
\text { R-number }\end{array}$ & $\begin{array}{c}\% \\
\text { carbon }\end{array}$ & $\begin{array}{c}\text { MS bottle } \\
\text { number }\end{array}$ & $\begin{array}{l}\text { mg carbon } \\
\text { in bottle }\end{array}$ & $\begin{array}{c}\delta^{13} \mathrm{C} \\
\% 0 \\
\end{array}$ \\
\hline \multirow{2}{*}{ O1Rx } & \multirow{2}{*}{$28770 / 1$} & \multirow{2}{*}{0.40} & RRL-48 & 0.22 & -28.01 \\
\hline & & & RRL-49 & 0.22 & -27.94 \\
\hline \multirow{2}{*}{ O3Rx } & \multirow{2}{*}{$28770 / 2$} & \multirow{2}{*}{0.57} & RRL-50 & 0.11 & -29.22 \\
\hline & & & RRL-51 & 0.11 & -28.97 \\
\hline \multirow{2}{*}{ O4Rx } & \multirow{2}{*}{$28770 / 3$} & \multirow{2}{*}{0.34} & RRL-52 & 0.07 & -28.73 \\
\hline & & & RRL-53 & 0.07 & -29.30 \\
\hline \multirow{2}{*}{ O5Rx } & \multirow{2}{*}{$28770 / 4$} & \multirow{2}{*}{0.38} & RRL-54 & 0.10 & -29.12 \\
\hline & & & RRL-55 & 0.10 & -30.04 \\
\hline \multirow{2}{*}{ O7Rx } & \multirow{2}{*}{$28770 / 5$} & \multirow{2}{*}{1.22} & RRL-56 & 0.06 & -28.93 \\
\hline & & & RRL-57 & 0.06 & -29.08 \\
\hline \multirow{2}{*}{ O8Rx } & \multirow{2}{*}{$28770 / 6$} & \multirow{2}{*}{1.11} & RRL-58 & 0.06 & -29.75 \\
\hline & & & RRL-59 & 0.06 & -29.65 \\
\hline \multirow{2}{*}{ O9Rx } & \multirow{2}{*}{$28770 / 7$} & \multirow{2}{*}{0.35} & RRL-63 & 0.11 & -29.20 \\
\hline & & & RRL-64 & 0.11 & -29.89 \\
\hline \multirow[b]{2}{*}{ O10Rx } & \multirow[b]{2}{*}{$28770 / 8$} & \multirow[b]{2}{*}{0.45} & RRL-66 & 0.11 & -29.40 \\
\hline & & & RRL-67 & 0.11 & $\begin{array}{c}-29.46+/-0.2 \\
\text { or }-27.7+/-0.2\end{array}$ \\
\hline
\end{tabular}

John Carter Phytolith samples for $\delta^{13}$ C only: R 28795/1-4

\begin{tabular}{|c|c|c|c|c|c|}
\hline $\begin{array}{c}\text { Sample } \\
\text { ID }\end{array}$ & $\begin{array}{c}\text { Rafter } \\
\text { R-number }\end{array}$ & $\begin{array}{c}\% \\
\text { carbon }\end{array}$ & $\begin{array}{c}\text { MS bottle } \\
\text { number }\end{array}$ & $\begin{array}{l}\text { mg carbon } \\
\text { in bottle }\end{array}$ & $\begin{array}{c}\delta^{13} \mathrm{C} \\
\% \mathrm{o}\end{array}$ \\
\hline \multirow{2}{*}{$\mathrm{O} 2 \mathrm{Rx}$} & \multirow{2}{*}{$28795 / 1$} & \multirow{2}{*}{0.80} & RRL-01 & 0.37 & -26.78 \\
\hline & & & RRL-02 & 0.37 & -26.73 \\
\hline \multirow{2}{*}{ O6Rx } & \multirow{2}{*}{$28795 / 2$} & \multirow{2}{*}{0.25} & RRL-03 & 0.08 & -28.90 \\
\hline & & & RRL-04 & 0.08 & -29.01 \\
\hline \multirow{2}{*}{ O15Rx } & \multirow{2}{*}{$28795 / 3$} & \multirow{2}{*}{0.24} & RRL-06 & 0.07 & -31.74 \\
\hline & & & RRL-07 & 0.07 & $-30.98 *$ \\
\hline \multirow{2}{*}{ O35Rx } & \multirow{2}{*}{$28795 / 4$} & \multirow{2}{*}{0.39} & RRL-08 & 0.22 & -34.17 \\
\hline & & & RRL-09 & 0.22 & $-33.99 *$ \\
\hline
\end{tabular}

* Not reliable results. 
John Carter Phytolith samples for $\delta^{13} \mathrm{C}$ only: R 28683/1-22

\begin{tabular}{|c|c|c|c|c|c|}
\hline $\begin{array}{c}\text { Sample } \\
\text { ID }\end{array}$ & $\begin{array}{c}\text { Rafter } \\
\text { R-number }\end{array}$ & $\begin{array}{c}\% \\
\text { carbon }\end{array}$ & $\begin{array}{c}\text { MS bottle } \\
\text { number }\end{array}$ & $\begin{array}{c}\text { mg carbon } \\
\text { in bottle }\end{array}$ & $\begin{array}{c}\delta^{13} \mathrm{C}, \\
\% 0\end{array}$ \\
\hline \multirow{2}{*}{ O1R } & \multirow{2}{*}{ 28683/1 } & \multirow{2}{*}{0.61} & RRL-24 & 0.24 & No result \\
\hline & & & RRL-25 & 0.24 & -3.91 \\
\hline \multirow[b]{2}{*}{ O3R } & \multirow[b]{2}{*}{$28683 / 2$} & \multirow[b]{2}{*}{2.2} & RRL-48 & 0.11 & -27.83 \\
\hline & & & RRL-49 & 0.11 & $\begin{array}{c}-23.4 \\
\text { (approx) } \\
\end{array}$ \\
\hline \multirow{2}{*}{$\mathrm{O} 4 \mathrm{R}$} & \multirow{2}{*}{$28683 / 3$} & \multirow{2}{*}{0.76} & RRL-44 & 0.07 & No result \\
\hline & & & RRL-46 & 0.07 & No result \\
\hline \multirow{2}{*}{$\mathrm{O} 5 \mathrm{R}$} & \multirow{2}{*}{$28683 / 4$} & \multirow{2}{*}{0.71} & RRL-66 & 0.09 & -28.08 \\
\hline & & & RRL-67 & 0.09 & No result \\
\hline \multirow{2}{*}{ O7R } & \multirow{2}{*}{$28683 / 5$} & \multirow{2}{*}{0.35} & RRL-57 & 0.09 & -14.7 \\
\hline & & & RRL-58 & 0.09 & $-14.74,-24.7$ \\
\hline \multirow{2}{*}{ O8R } & \multirow{2}{*}{$28683 / 6$} & \multirow{2}{*}{0.43} & RRL-55 & 0.07 & No result \\
\hline & & & RRL-56 & 0.07 & -26.5 \\
\hline \multirow{2}{*}{ O9R } & \multirow{2}{*}{$28683 / 7$} & \multirow{2}{*}{0.56} & RRL-12 & 0.07 & No result \\
\hline & & & RRL-64 & 0.07 & No result \\
\hline \multirow{2}{*}{ O10R } & \multirow{2}{*}{$28683 / 8$} & \multirow{2}{*}{0.35} & RRL-30 & 0.11 & No result \\
\hline & & & RRL-31 & 0.11 & $-27.2+/-0.2$ \\
\hline & & & RRL-23 & 0.18 & -30.26 \\
\hline OHR & $28683 / 9$ & 0.28 & RRL-24 & 0.18 & -30.32 \\
\hline Q12R & $28683 / 10$ & 020 & RRL-25 & 0.15 & -30.36 \\
\hline OI $2 \mathrm{~K}$ & $28083 / 10$ & 0.29 & RRL-26 & 0.15 & -30.64 \\
\hline O13R & $28683 / 11$ & 031 & RRL-27 & 0.20 & -31.81 \\
\hline תוJא & $28083 / 11$ & 0.31 & RRL-28 & 0.20 & -31.70 \\
\hline & & & RRL-29 & 0.09 & -33.68 \\
\hline O14R & $28683 / 12$ & 0.28 & RRL-30 & 0.09 & -33.60 \\
\hline & & & RRL-13 & 0.04 & -32.71 \\
\hline OI6R & $28683 / 13$ & 0.38 & RRL-14 & 0.04 & -32.85 \\
\hline & & & RRL-15 & 0.13 & -30.50 \\
\hline O18R & 28683/14 & 0.80 & RRL-16 & 0.13 & -30.67 \\
\hline $\mathrm{O} 19 \mathrm{R}$ & & 071 & RRL-17 & 0.13 & -29.89 \\
\hline O19R & $28683 / 15$ & 0.11 & RRL-18 & 0.13 & -30.06 \\
\hline $\mathrm{O} 20 \mathrm{R}$ & $28683 / 16$ & 070 & RRL-19 & 0.12 & -30.24 \\
\hline ULOK & $28683 / 16$ & 0.10 & RRL-20 & 0.12 & -30.12 \\
\hline & & & RRL-21 & 0.06 & -30.06 \\
\hline $\mathrm{O} 22 \mathrm{R}$ & $28683 / 17$ & 0.43 & RRL-22 & 0.06 & -30.22 \\
\hline O23R & $28683 / 18$ & & RRL-28 & 0.07 & -29.48 \\
\hline O23R & 28683/18 & 0.48 & RRL-29 & 0.07 & -29.75 \\
\hline $024 \mathrm{R}$ & $28683 / 19$ & 041 & RRL-53 & 0.04 & -32.13 \\
\hline $0 \angle 4 \mathrm{~K}$ & $28083 / 19$ & 0.41 & RRL-56 & 0.04 & -32.13 \\
\hline $\mathrm{O} 25 \mathrm{R}$ & & & RRL-23 & 0.06 & -30.10 \\
\hline ULJK & $28683 / 20$ & 0.56 & RRL-26 & 0.06 & -30.75 \\
\hline & & & RRL-17 & 0.08 & -29.64 \\
\hline $\mathrm{O} 21 \mathrm{R}$ & $28683 / 21$ & 0.52 & RRL-19 & 0.08 & -30.07 \\
\hline & & & RRL-13 & 0.17 & -30.47 \\
\hline $01 / \mathrm{K}$ & $28683 / 22$ & 0.94 & RRL-15 & 0.17 & -30.43 \\
\hline
\end{tabular}


Stable Isotope Laboratory Isotope Report

Client: Dr John Carter

$V U W$

Attn:

Client Reference: Phytoliths, email 26/11/03

SIL Order No: 2551, 2586, 2614,

Date: 14 August 2007

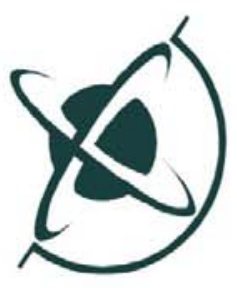

Institute of

GEOLOGICAL

\& NUCLEAR

SCIENCES

Limited

\begin{tabular}{llll}
\hline Sample Name & $\boldsymbol{R} \boldsymbol{R} \boldsymbol{L} \boldsymbol{L a b} \boldsymbol{N o}$ & $\% \boldsymbol{C}$ & $\delta^{13} \boldsymbol{C}(\boldsymbol{\%})$ \\
\hline & & & \\
O26 & $\mathrm{R} 28386 / 1$ & 0.36 & -28.0 \\
O27 & $\mathrm{R} 28386 / 2$ & 0.34 & -28.1 \\
O28 & $\mathrm{R} 28386 / 3$ & 0.21 & -28.4 \\
O29 & $\mathrm{R} 28386 / 4$ & 0.30 & -28.9 \\
O30 & $\mathrm{R} 28386 / 5$ & 0.30 & -30.0 \\
O31 & $\mathrm{R} 28386 / 6$ & 0.33 & -30.6 \\
O32 & $\mathrm{R} 28386 / 7$ & 0.30 & -32.6 \\
O33 & $\mathrm{R} 28386 / 8$ & 0.35 & -33.6 \\
O34 & $\mathrm{R} 28386 / 9$ & 0.35 & -34.0 \\
O36 & $\mathrm{R} 28386 / 10$ & 0.36 & -34.0 \\
O37 & $\mathrm{R} 28386 / 11$ & 0.37 & -33.9 \\
O38 & $\mathrm{R} 28386 / 12$ & 0.36 & -33.9 \\
O39 & $\mathrm{R} 28386 / 13$ & 0.39 & -33.7 \\
O40 & $\mathrm{R} 28386 / 14$ & 0.37 & -33.4
\end{tabular}

All these samples were prepared for analysis using the sealed tube method, by the Rafter Radiocarbon Lab. All $\delta^{13} \mathrm{C}$ measurements are with respect to VPDB, and have isotope analytical errors of $\pm 0.1 \%$.

The labels in brackets are from John Carter's emailed list, beside the nearest equivalent from the sample labels supplied to the RRL.

Samples will be kept for 3 months from the date of this report and then discarded unless otherwise notified. Results approved for release by Graeme Lyon. (rafterisotopes@gns.cri.nz). 
John Carter Phytolith samples for $\delta^{13} \mathrm{C}$ only: R 28761/1-35

\begin{tabular}{|c|c|c|c|c|c|}
\hline $\begin{array}{c}\text { Sample } \\
\text { ID }\end{array}$ & $\begin{array}{c}\text { Rafter } \\
\text { R-number }\end{array}$ & $\begin{array}{c}\% \\
\text { carbon }\end{array}$ & $\begin{array}{c}\text { MS bottle } \\
\text { number }\end{array}$ & $\begin{array}{c}\text { mg carbon } \\
\text { in bottle }\end{array}$ & $\begin{array}{c}\delta^{13} \mathrm{C}, \\
\% 0\end{array}$ \\
\hline \multirow{2}{*}{$\mathrm{O} 41$} & \multirow{2}{*}{$28761 / 1$} & \multirow{2}{*}{0.43} & RRL-28 & 0.16 & -31.83 \\
\hline & & & RRL-29 & 0.16 & -32.05 \\
\hline \multirow[t]{2}{*}{$\mathrm{O} 42$} & \multirow[t]{2}{*}{$28761 / 2$} & \multirow[t]{2}{*}{0.54} & RRL-30 & 0.07 & $\begin{array}{c}-28.70+/- \\
0.02\end{array}$ \\
\hline & & & RRL-31 & 0.07 & $-30.0+/-0.2$ \\
\hline \multirow{2}{*}{$\mathrm{O} 43$} & \multirow{2}{*}{$28761 / 3$} & \multirow{2}{*}{0.60} & RRL-32 & 0.04 & $-27.7+/-0.2$ \\
\hline & & & RRL-33 & 0.04 & -28.38 \\
\hline \multirow{2}{*}{$\mathrm{O} 44$} & \multirow{2}{*}{$28761 / 4$} & \multirow{2}{*}{0.56} & RRL-34 & 0.05 & -29.13 \\
\hline & & & RRL-35 & 0.05 & -29.06 \\
\hline \multirow{2}{*}{$\mathrm{O} 45$} & \multirow{2}{*}{$28761 / 5$} & \multirow{2}{*}{0.55} & RRL-36 & 0.05 & -28.71 \\
\hline & & & RRL-37 & 0.05 & -28.74 \\
\hline \multirow{2}{*}{$\mathrm{O} 45 \mathrm{X}$} & \multirow{2}{*}{$28761 / 6$} & \multirow{2}{*}{0.51} & RRL-18 & 0.05 & -28.26 \\
\hline & & & RRL-19 & 0.05 & No result \\
\hline \multirow{2}{*}{ O46 } & \multirow{2}{*}{$28761 / 7$} & \multirow{2}{*}{0.69} & RRL-20 & 0.04 & -28.87 \\
\hline & & & RRL-26 & 0.04 & No result \\
\hline \multirow{2}{*}{$\mathrm{O} 47$} & \multirow{2}{*}{$28761 / 8$} & \multirow{2}{*}{0.60} & RRL-27 & 0.05 & No result \\
\hline & & & RRL-29 & 0.05 & -25.97 \\
\hline & & & RRL-30 & 0.05 & -26.79 \\
\hline 048 & $28 / 61 / 9$ & 0.19 & RRL-31 & 0.05 & -26.74 \\
\hline 040 & $28761 / 10$ & 076 & RRL-32 & 0.06 & -26.32 \\
\hline 049 & $28 / 01 / 10$ & 0.10 & RRL-33 & 0.06 & -26.59 \\
\hline 050 & $28761 / 11$ & 076 & Pyrex tube & 0.06 & -26.0 \\
\hline 050 & $28 / 01 / 11$ & 0.10 & Pyrex tube & 0.06 & \\
\hline & & & Pyrex tube & 0.03 & -28.4 \\
\hline US1 & $28 / 61 / 12$ & 0.62 & Pyrex tube & 0.03 & \\
\hline & & & Pyrex tube & 0.05 & -28.9 \\
\hline 052 & $28 / 61 / 13$ & 0.65 & Pyrex tube & 0.05 & \\
\hline & & & Pyrex tube & 0.06 & -27.5 \\
\hline 053 & $28761 / 14$ & 0.64 & Pyrex tube & 0.06 & \\
\hline 054 & $28761 / 15$ & 0.64 & Pyrex tube & 0.07 & -27.0 \\
\hline 43 & $20 / 01 / 10$ & 0.04 & Pyrex tube & 0.07 & \\
\hline 055 & $28761 / 16$ & 083 & Quartz tube & 0.07 & -27.4 \\
\hline U55 & $28 / 61 / 16$ & 0.83 & Quartz tube & Lost & \\
\hline 056 & $28761 / 17$ & 060 & Quartz tube & 0.10 & -28.0 \\
\hline 050 & $28 / 01 / 1 /$ & 0.00 & Quartz tube & 0.10 & \\
\hline O57 & $28761 / 18$ & 0.42 & Quartz tube & 0.15 & -28.9 \\
\hline 057 & $28 / 61 / 18$ & 0.42 & Quartz tube & 0.15 & \\
\hline 058 & $28761 / 19$ & 049 & Quartz tube & 0.15 & -29.3 \\
\hline 058 & $28 / 01 / 19$ & 0.49 & Quartz tube & 0.15 & \\
\hline 059 & $28761 / 20$ & 030 & Quartz tube & 0.09 & -30.0 \\
\hline (4) & $20 / 01 / 20$ & 0.39 & Quartz tube & 0.09 & \\
\hline & & & Pyrex tube & 0.11 & -31.1 \\
\hline 060 & $28761 / 21$ & 0.33 & Pyrex tube & 0.11 & \\
\hline 061 & & & Pyrex tube & 0.17 & -32.3 \\
\hline 061 & $28 / 61 / 22$ & 0.32 & Pyrex tube & 0.17 & \\
\hline
\end{tabular}




\begin{tabular}{|c|c|c|c|c|c|}
\hline $\begin{array}{c}\text { Sample } \\
\text { ID }\end{array}$ & $\begin{array}{c}\text { Rafter } \\
\text { R-number }\end{array}$ & $\begin{array}{c}\% \\
\text { carbon }\end{array}$ & $\begin{array}{c}\text { MS bottle } \\
\text { number }\end{array}$ & $\begin{array}{l}\text { mg carbon } \\
\text { in bottle }\end{array}$ & $\begin{array}{c}\delta^{13} \mathrm{C} \\
\%\end{array}$ \\
\hline \multirow{2}{*}{ O62 } & \multirow{2}{*}{$28761 / 23$} & \multirow{2}{*}{0.34} & Pyrex tube & 0.18 & -31.0 \\
\hline & & & Pyrex tube & 0.18 & \\
\hline \multirow{2}{*}{ O63 } & \multirow{2}{*}{$28761 / 24$} & \multirow{2}{*}{0.36} & Pyrex tube & 0.18 & -30.5 \\
\hline & & & Pyrex tube & 0.18 & \\
\hline \multirow{2}{*}{ O64 } & \multirow{2}{*}{$28761 / 25$} & \multirow{2}{*}{0.31} & Pyrex tube & 0.17 & -30.5 \\
\hline & & & Pyrex tube & 0.17 & \\
\hline \multirow{2}{*}{ O65 } & \multirow{2}{*}{$28761 / 26$} & \multirow{2}{*}{0.32} & Pyrex tube & 0.17 & -31.1 \\
\hline & & & Pyrex tube & 0.17 & \\
\hline \multirow{2}{*}{ O66 } & \multirow{2}{*}{$28761 / 27$} & \multirow{2}{*}{0.34} & Pyrex tube & 0.17 & -30.7 \\
\hline & & & Pyrex tube & 0.17 & \\
\hline \multirow{2}{*}{ O67 } & \multirow{2}{*}{$28761 / 28$} & \multirow{2}{*}{0.31} & Pyrex tube & 0.17 & -31.7 \\
\hline & & & Pyrex tube & 0.17 & \\
\hline \multirow{2}{*}{ O68 } & \multirow{2}{*}{$28761 / 29$} & \multirow{2}{*}{0.31} & Pyrex tube & 0.16 & -31.1 \\
\hline & & & Pyrex tube & 0.16 & \\
\hline \multirow{2}{*}{ O69 } & \multirow{2}{*}{$28761 / 30$} & \multirow{2}{*}{0.31} & Pyrex tube & 0.17 & -31.1 \\
\hline & & & Pyrex tube & 0.17 & \\
\hline \multirow{2}{*}{$\mathrm{O} 70$} & \multirow{2}{*}{$28761 / 31$} & \multirow{2}{*}{0.32} & Pyrex tube & 0.17 & -29.5 \\
\hline & & & Pyrex tube & 0.17 & \\
\hline \multirow{2}{*}{ O71 } & \multirow{2}{*}{$28761 / 32$} & \multirow{2}{*}{0.31} & Pyrex tube & 0.14 & -31.4 \\
\hline & & & Pyrex tube & 0.14 & \\
\hline \multirow{2}{*}{$\mathrm{O} 72$} & \multirow{2}{*}{$28761 / 33$} & \multirow{2}{*}{0.34} & Pyrex tube & 0.16 & -31.7 \\
\hline & & & Pyrex tube & 0.16 & \\
\hline 073 & $28761 / 34$ & 034 & Pyrex tube & 0.19 & -32.0 \\
\hline $0 / 3$ & $28 / 01 / 34$ & 0.34 & Pyrex tube & 0.19 & \\
\hline O74 & $28761 / 35$ & 0.34 & Pyrex tube & 0.19 & -31.7 \\
\hline & & 0.34 & Pyrex tube & 0.19 & \\
\hline
\end{tabular}


Appendix 5: Analysis of $\delta^{13} \mathrm{C}$ Analysis from Plant and Phytolith from Pilot Study. All samples marked in red were discarded and new samples extracted from the sediments and analysed.

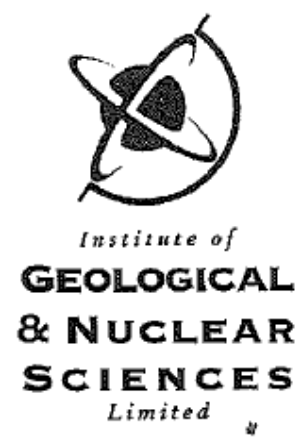

Stable Isotope Laboratory

\& NUCLEAR

Limited

Stable Isotope Results

\begin{tabular}{lll}
\hline \hline Client: & Victoria University of Wellington & SIL Order No.: 1930 \\
Attn: & John Carter & Date: $15^{\text {th }}$ November 2002 \\
Client Ref/Proi No. Commercial & \\
\hline \hline
\end{tabular}

$\begin{array}{lll}\text { Sample Name } & \underline{\% \mathrm{C}} & \underline{\delta^{13} \mathrm{C}} \\ \text { BM 374 } & 0.19 & -29.3 \\ \text { BM 374 } & 0.18 & -30.2 \\ \text { BM 550 } & 0.15 & -29.8 \\ \text { BM 550 } & 0.12 & -30.2 \\ \text { CIT 3 } & 0.53 & -32.4 \\ \text { CIT 3 } & 0.53 & -32.5 \\ \text { CIT 4 } & 0.15 & -30.3 \\ \text { CIT 4 } & 0.14 & -30.8 \\ \text { CIT 5 } & 0.13 & -29.7 \\ \text { CIT 5 } & 0.16 & -30.2 \\ \text { CIT 6 } & 0.21 & -29.1 \\ \text { CIT 6 } & 0.22 & -29.2 \\ \text { CIT 7 } & 0.50 & -30.0 \\ \text { CIT 7 } & 0.44 & -30.1 \\ \text { CR 3 } & 44.55 & -26.8 \\ \text { CR 3 } & 44.39 & -26.8 \\ \text { CR2 } & 44.60 & -29.8 \\ \text { CR2 } & 42.71 & -29.4 \\ \text { NF 2 } & 45.71 & -30.6 \\ \text { NF 2 } & 45.71 & -30.5 \\ \text { NF 1 } & 44.96 & -28.8 \\ \text { NF 1 } & 44.21 & -28.8 \\ \text { F n 1 } & 43.86 & -26.9 \\ \text { F n 1 } & 43.49 & -26.8\end{array}$

Stable lsotope Laboratory, Rafter Building

PO Box 31312, Lower Hutt, New Zealand, Telephone: +64.4 .5704637 , Facsimile: +64.4 .5704657$

Delivery Address: 30 Gracefield Road, Lower Hutt, New Zealand 


\title{
Stable Isotope Laboratory
}

\section{GEOLOGICAL \\ \& NUCLEAR \\ SCIENCES \\ Limited}

\author{
Stable Isotope Results
}

\begin{tabular}{lll} 
Client: & Victoria University of Wellington & SIL Order No.: 2006 \\
Attn: & John Carter & Date: $23^{\text {rd }}$ January 2003 \\
Client Ref/Proj No. Commercial & \\
\hline \hline
\end{tabular}

$\begin{array}{cccc}\text { Sample Name } & & \underline{\% \mathrm{C}} & \underline{\delta^{13} \mathrm{C}} \\ \text { CIT09 } & 0.16 & -28.8 \\ \text { CIT09 } & 0.16 & -28.9 \\ \text { CIT035 } & 0.24 & -36.2 \\ \text { CIT035 } & 0.22 & -35.8 \\ \text { CIT8 } & 2.32 & -29.0 \\ \text { CIT9 } & 0.29 & -28.1 \\ \text { CIT9 } & 0.27 & -27.8 \\ \text { CIT10 } & 0.10 & -28.9 \\ \text { CIT10 } & 0.13 & -27.9 \\ \text { CIT11 } & 0.11 & -28.7 \\ \text { CIT11 } & 0.12 & -27.6 \\ & & \\ \text { CD1 } & 40.4 & -29.1 \\ \text { CD1 } & 41.8 & -29.2 \\ \text { CM1 } & 43.0 & -26.6 \\ \text { CM1 } & 43.2 & -26.6 \\ \text { DD1 } & 48.6 & -31.1 \\ \text { DD1 } & 51.7 & -30.9 \\ \text { KE1 } & 45.1 & -28.8 \\ \text { KE1 } & 46.5 & -28.7\end{array}$

All analyses carried out by Dr Graeme Lyon at GNS. All measurements are normalised to VPDB using NBS-22 (International Standard) and ANU-sucrose (International Standard) with a precision of $\pm 0.1 \%$ for $\delta^{13} \mathrm{C}$.

Samples were analysed in duplicate as listed and results should be averaged and quoted to \pm 0.1 $\%$.

Samples will be destroyed after 3 months unless you advise otherwise. 


\section{Appendix 6: Analysis of $\delta^{13} \mathrm{C}$ Analysis from Plants from Main Study (First Suite)}

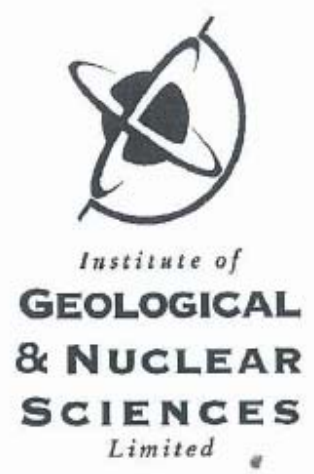

Stable Isotope Laboratory

Stable Isotope Results

\begin{tabular}{lll}
\hline \hline Client: & Victoria University of Wellington & SIL Order No.: 2388 \\
Attn: & John Carter & Date: 19 November 2003 \\
Client Ref/Proj No. Commercial &
\end{tabular}

\begin{tabular}{|c|c|c|c|c|c|c|c|c|}
\hline Sample & weight & $\begin{array}{c}N \text { beam } \\
\text { size }\end{array}$ & $\% \mathrm{~N}$ & d15N & $\begin{array}{c}C \text { beam } \\
\text { size }\end{array}$ & $\% \mathrm{C}$ & d13C & $\begin{array}{l}\mathrm{C}: \mathrm{N} \\
\text { ratio }\end{array}$ \\
\hline \multirow[t]{2}{*}{ nss-p } & 2.83 & $1.53 \mathrm{E}-07$ & 1.21 & -0.21 & $2.45 \mathrm{E}-06$ & 44.87 & -29.98 & 37.27 \\
\hline & 3.14 & $1.75 \mathrm{E}-07$ & 1.24 & -0.15 & $2.28 \mathrm{E}-06$ & 45.49 & -30.12 & 37.66 \\
\hline \multirow[t]{2}{*}{$n m-p$} & 0.97 & $2.04 \mathrm{E}-07$ & 1.44 & 1.88 & 2.32E-06 & 49.02 & -30.97 & 34.11 \\
\hline & 0.98 & $2.19 \mathrm{E}-07$ & 1.45 & 2.30 & 2.27E-06 & 48.98 & -30.74 & 33.85 \\
\hline \multirow[t]{2}{*}{$n s c-p$} & 1.14 & 7.85E-08 & 1.52 & 0.84 & $2.59 \mathrm{E}-06$ & 46.85 & -30.69 & 30.82 \\
\hline & 1 & 7.37E-08 & 1.62 & 0.54 & 2.32E-06 & 47.60 & -30.72 & 29.38 \\
\hline \multirow[t]{2}{*}{$n f-p$} & 0.99 & $6.87 \mathrm{E}-08$ & 1.42 & & $2.21 \mathrm{E}-06$ & 44.63 & -29.94 & 31.36 \\
\hline & 1.13 & $7.14 \mathrm{E}-08$ & 1.38 & & $2.39 \mathrm{E}-06$ & 42.98 & -29.90 & 31.19 \\
\hline \multirow[t]{2}{*}{ CR-P } & 8.19 & $1.99 \mathrm{E}-07$ & 0.59 & 3.08 & 8.53E-06 & 48.52 & -29.66 & 82.57 \\
\hline & 8.2 & 1.87E-07 & 0.58 & 3.36 & $8.38 \mathrm{E}-06$ & 48.22 & -29.78 & 82.91 \\
\hline \multirow[t]{2}{*}{$f n z-p$} & 1.11 & $2.53 \mathrm{E}-08$ & 0.52 & 1.60 & $2.27 \mathrm{E}-06$ & 43.86 & -28.38 & 83.64 \\
\hline & 1.04 & 2.30E-08 & 0.49 & 1.63 & $2.20 \mathrm{E}-06$ & 41.32 & -28.48 & 84.93 \\
\hline \multirow[t]{2}{*}{ al-p } & 2.96 & 1.03E-07 & 0.77 & 1.83 & $6.51 \mathrm{E}-06$ & 43.45 & -28.33 & 56.44 \\
\hline & 1.09 & 3.99E-08 & 0.88 & 1.97 & 2.43E-06 & 49.91 & -28.44 & 56.75 \\
\hline \multirow[t]{2}{*}{ bt-p } & 1.09 & 7.96E-08 & 1.83 & 4.06 & $2.39 \mathrm{E}-06$ & 51.39 & -29.16 & 28.07 \\
\hline & 1.14 & $8.79 E-08$ & 1.98 & 4.22 & $2.56 \mathrm{E}-06$ & 53.90 & -29.36 & 27.26 \\
\hline \multirow[t]{2}{*}{ WR-P } & 2.2 & $1.26 \mathrm{E}-07$ & 1.22 & 4.15 & 5.29E-06 & 48.46 & -28.00 & 39.75 \\
\hline & 2.01 & $1.13 \mathrm{E}-07$ & 1.20 & 3.44 & 4.84E-06 & 48.52 & -28.20 & 40.53 \\
\hline dd-p & 3.01 & $1.94 \mathrm{E}-07$ & 1.43 & 10.93 & $6.91 \mathrm{E}-06$ & 47.20 & -30.03 & 33.12 \\
\hline
\end{tabular}




$\begin{array}{lcccccccc} & 3.24 & 2.18 \mathrm{E}-07 & 1.44 & 11.11 & 7.30 \mathrm{E}-06 & 48.28 & -30.09 & 33.53 \\ \text { dc-p } & 1.28 & 7.49 \mathrm{E}-08 & 1.28 & 1.06 & 3.01 \mathrm{E}-06 & 48.91 & -30.14 & 38.24 \\ & 1.15 & 6.94 \mathrm{E}-08 & 1.32 & 0.88 & 2.82 \mathrm{E}-06 & 50.39 & -30.42 & 38.20 \\ \text { NT-P } & 2.9 & 1.74 \mathrm{E}-07 & 1.32 & 1.53 & 6.63 \mathrm{E}-06 & 44.95 & -28.83 & 34.05 \\ & 3.06 & 1.82 \mathrm{E}-07 & 1.31 & 1.51 & 6.92 \mathrm{E}-06 & 44.50 & -29.17 & 33.97\end{array}$

All analyses carried out by Dr Karyne Rogers at GNS. All measurements are normalised to VPDB using NBS-22 (International Standard) and ANU-sucrose (International Standard) with a precision of $\pm 0.1 \%$ for $\delta^{13} \mathrm{C}$.

Samples were analysed in duplicate as listed and results should be averaged and quoted to \pm 0.1 $\%$.

Samples will be destroyed after 3 months unless you advise otherwise.

Results approved for release by Karyne Rogers. (rafterisotopes@gns.cri.nz). 
(Second Suite)

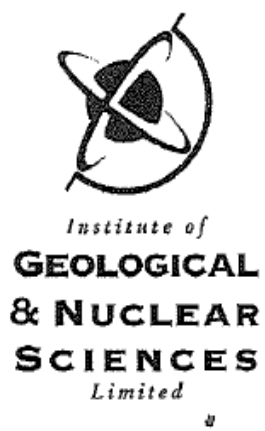

Stable Isotope Laboratory

GEOLOGICAL

\& NUCLEAR

Limited

Stable Isotope Results

Client: Victoria University of Wellington SIL Order No.: 2806

Attn: John Carter Date: 20 June 2004

Client Ref/Proj No. Commercial

\begin{tabular}{|c|c|c|c|c|c|c|c|c|}
\hline Sample & weight & $\begin{array}{l}N \text { beam } \\
\text { size }\end{array}$ & $\% \mathrm{~N}$ & $\mathrm{~d} 15 \mathrm{~N}$ & $\begin{array}{l}C \text { beam } \\
\text { size }\end{array}$ & $\% \mathrm{C}$ & d13C & $\begin{array}{l}\mathrm{C}: \mathrm{N} \\
\text { ratio }\end{array}$ \\
\hline \multirow[t]{2}{*}{ bt 2} & 2.13 & 1.93E-07 & 1.62 & 1.06 & $3.85 \mathrm{E}-06$ & 42.33 & -31.01 & 30.48 \\
\hline & 2.03 & $1.84 \mathrm{E}-07$ & 1.62 & 1.14 & $3.76 \mathrm{E}-06$ & 43.55 & -30.87 & 31.36 \\
\hline \multirow[t]{2}{*}{$\mathrm{nsc}$} & 1.95 & 1.52E-07 & 1.38 & 0.16 & $3.74 \mathrm{E}-06$ & 45.19 & -29.60 & 38.20 \\
\hline & 2.08 & $1.58 \mathrm{E}-07$ & 1.35 & 0.27 & $4.05 E-06$ & 45.96 & -29.82 & 39.72 \\
\hline \multirow[t]{2}{*}{$\mathrm{dd}$} & 1.95 & $1.07 E-07$ & 0.97 & -0.45 & $3.94 \mathrm{E}-06$ & 47.76 & -29.83 & 57.44 \\
\hline & 2.09 & $1.10 \mathrm{E}-07$ & 0.93 & -0.69 & 4.21E-06 & 47.76 & -29.70 & 59.91 \\
\hline \multirow[t]{2}{*}{$\mathrm{nm}$} & 1.96 & 1.33E-07 & 1.20 & -0.51 & $3.73 E-06$ & 45.42 & -27.14 & 44.16 \\
\hline & 2.01 & $1.40 \mathrm{E}-07$ & 1.23 & -0.57 & $3.89 E-06$ & 46.23 & -27.21 & 43.85 \\
\hline \multirow[t]{2}{*}{ ai } & 1.91 & 1.37E-07 & 1.27 & 0.37 & $3.47 \mathrm{E}-06$ & 43.36 & -30.05 & 39.83 \\
\hline & 2.01 & 1.39E-07 & 1.23 & 0.42 & $3.72 \mathrm{E}-06$ & 44.13 & -30.02 & 41.86 \\
\hline \multirow[t]{2}{*}{ nt $2 p$} & 2.02 & $1.61 \mathrm{E}-07$ & 1.41 & 0.13 & 4.11E-06 & 48.52 & -29.39 & 40.15 \\
\hline & 2.09 & $1.74 \mathrm{E}-07$ & 1.47 & 0.16 & 4.39E-06 & 50.07 & -29.36 & 39.74 \\
\hline \multirow[t]{2}{*}{$\mathrm{wr}$} & 2.17 & $1.41 \mathrm{E}-07$ & 1.15 & 1.31 & $4.43 \mathrm{E}-06$ & 48.70 & -29.09 & 49.41 \\
\hline & 2.25 & $1.38 \mathrm{E}-0.7$ & 1.09 & 1.12 & 4.31E-06 & 45.75 & -29.23 & 48.97 \\
\hline \multirow[t]{2}{*}{ fnz } & 2.01 & 4.93E-08 & 1.50 & 1.01 & 2.87E-06 & 34.00 & -27.87 & 26.44 \\
\hline & 2.05 & $5.18 \mathrm{E}-08$ & 1.51 & 0.56 & $3.01 \mathrm{E}-06$ & 34.93 & -27.90 & 26.99 \\
\hline \multirow[t]{2}{*}{ nf $2 p$} & 2.17 & $1.80 \mathrm{E}-07$ & 1.50 & -0.42 & 4.15E-06 & 45.55 & -29.70 & 35.43 \\
\hline & 1.96 & 1.67E-07 & 1.54 & -0.60 & $3.69 \mathrm{E}-06$ & 44.82 & -29.76 & 33.95 \\
\hline \multirow[t]{2}{*}{$\mathrm{Cr}$} & 2.18 & $6.61 \mathrm{E}-08$ & 0.50 & -0.98 & 3.84E-06 & 41.85 & -29.20 & 97.65 \\
\hline & 2 & $5.66 \mathrm{E}-08$ & 0.50 & -1.15 & 3.47E-06 & 41.21 & -29.20 & 96.16 \\
\hline \multirow[t]{2}{*}{ nss } & 1.95 & $1.16 \mathrm{E}-07$ & 1.09 & 0.07 & $3.72 E-06$ & 45.37 & -29.37 & 48.56 \\
\hline & 1.88 & $1.06 \mathrm{E}-07$ & 1.03 & -0.11 & 3.55E-06 & 44.81 & -29.26 & 50.76 \\
\hline \multirow[t]{2}{*}{ dc } & 2.18 & $1.53 E-07$ & 1.30 & 6.07 & 4.19E-06 & 45.40 & -30.64 & 40.74 \\
\hline & 1.95 & 1.35E-07 & 1.27 & 5.77 & 3.77E-06 & 45.59 & -30.71 & 41.88 \\
\hline
\end{tabular}

All analyses carried out by Dr Karyne Rogers at GNS. All measurements are normalised to VPDB using NBS-22 (International Standard) and ANU-sucrose (International Standard) with a precision of $\pm 0.1 \%$ for $\delta^{13} \mathrm{C}$.

Stable Isotope Laboratory, Rafter Building

PO Box 31312, Lower Hutt, New Zealand, Telephone: +64.4 .5704637 , Facsimile: +64.4 .5704657$

Delivery Address: 30 Gracefield Road, Lower Hutt, New Zealand

A Crown Research Institute 


\section{Appendix 7: Analysis of $\delta^{13} \mathrm{C}$ from Phytolith from Main Study (First and Second Suite) (Samples highlighted in red are those reported in}

Appendix 4 page 138).

\section{Stable Isotope Laboratory Isotope Report}

Client: Dr John Carter

$\checkmark U W$

Attn:

Client Reference: Phytoliths, email 26/11/03 SIL Order No: 2551, 2586, 2614 ,

Date: 25 February 2007

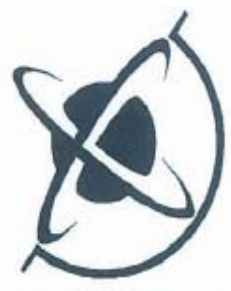

Institute of

GEOLOGICAL

\& NUCLEAR

SCIENCES

Limited

$\delta^{13} \mathrm{C}(\%)$

A.a 18 [A.1.1]
C.r.1
D.d.1
B.t.1
F.n.z.1
N.s.c.1
N.f.1
N.m.1
N.s.s.1
N.t.1
R4 [D.c.1]
W.r.1

$\mathrm{O} 26$

$\mathrm{O} 27$

$\mathrm{O} 28$

O29

O30

O31

O32

$\mathrm{O} 33$

O34

O36

O37

O38

O39

O40

$\begin{array}{lll}\text { R228385/1 } & 0.96 & -34.0 \\ \text { R28385/2 } & 0.39 & -33.1 \\ \text { R28385/3 } & 0.70 & -26.7 \\ \text { R28385/4 } & 0.62 & -30.5 \\ \text { R28385/5 } & 0.07 & -31.6 \\ \text { R28385/6 } & 0.17 & -28.0 \\ \text { R28385/7 } & 0.28 & -29.3 \\ \text { R28385/8 } & \text { To be replaced } & \\ \text { R28385/9 } & 0.15 & -27.2 \\ \text { R28385/10 } & 0.13 & -29.1 \\ \text { R28385/11 } & 0.84 & -31.6,-32.1 \\ \text { R28385/12 } & \text { To be replaced } & \end{array}$

R28386/1

0.36

$-28.0$

$-28.1$

$-28.4$

R28386/3

R28386/4

0.21

0.30

0.30

0.33

0.30

0.35

0.35

0.36

0.37

0.36

0.39

0.37

All these samples were prepared for analysis using the sealed tube method, by the Rafter Radiocarbon Lab. All $\delta^{13} \mathrm{C}$ measurements are with respect to VPDB, and have isotope analytical errors of $\pm 0.1 \%$.

The labels in brackets are from John Carter's emailed list, beside the nearest equivalent from the sample labels supplied to the RRL. 


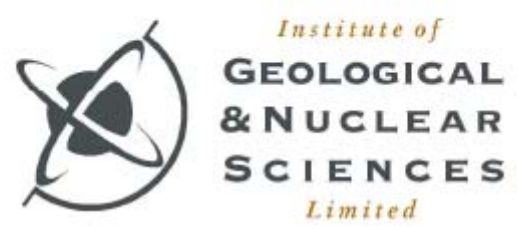

21 May 2004

Rafter Radiocarbon Laboratoy

Report of Stable Isotope results [SILs 2849, 2853] to:

John A. Carter

School of Earth Sciences

Victoria University of Wellington

\begin{tabular}{llll} 
Sample Name & RRL Lab No & $\% \mathrm{C}$ & $\delta^{13} \mathrm{C}(\%$ ) \\
\hline N.m. [1] R & & & \\
W.r. [1] R & R28540/1 (was R28385/8) & 0.06 & -29.24 \\
C.r. [2] & R28450/2 (was R28385/12) & 5.00 & -27.98 \\
F.n.z. [2] & R28539/1 & 0.1 & \\
A.1. [2] & R28539/2 & 0.06 & -30.22 \\
N.f. [2] & R28539/3 & 0.1 & -30.80 \\
N.s.s. [2] & R28539/4 & 0.13 & -31.81 \\
N.s.c. [2] & R28539/5 & 0.22 & -29.25 \\
N.m. [2] & R28539/6 & 0.14 & -29.96 \\
N.t. [2] & R28539/7 & 0.23 & -27.43 \\
D.c. [2] & R28539/8 & 0.61 & -29.12 \\
D.d. [2] & R28539/9 & 2.07 & -23.53 \\
B.t. [2] & R28539/10 & 4.1 & -27.63 \\
W.r. [2] & R28539/11 & -27.34 \\
& R28539/12 & 0.08 & -28.43 \\
& & 0.07 & -27.61
\end{tabular}

All samples were prepared using the sealed tube method.

Dawn Chambers (Ms)

Sample Coordinator

Rafter Radiocarbon Laboratory

email: d.chambers@gns.cri.nz

www.RafterRadiocarbon.co.nz 